\author{
UNIVERSIDADE DE SÃO PAULO
}

Faculdade de Filosofia, Letras e Ciências Humanas

MARIA DO ROSÁRIO MONTES GALLEGO

\title{
Decodificação do português (L2) falado por estrangeiros ingleses e americanos
}


MARIA DO ROSÁRIO MONTES GALLEGO

\section{Decodificação do português (L2) falado por estrangeiros ingleses e americanos}

Tese apresentada à Faculdade de Filosofia, Letras e Ciências Humanas da Universidade de São Paulo para obtenção do título de Doutor em Letras

Área de Concentração: Filologia e Língua Portuguesa

Orientadora: Prof. ${ }^{a}$ Dr. ${ }^{a}$ Guiomar Fanganiello Calçada 
PROIBIDA A REPRODUÇÃO E DIVULGAÇÃO TOTAL OU PARCIAL DESTE TRABALHO, POR QUALQUER MEIO CONVENCIONAL OU ELETRÔNICO, CONFORME LEI 9.610 (Lei de Direitos Autorais).

Serviço de Documentação da Faculdade de Filosofia, Letras e Ciências Humanas da Universidade de São Paulo

Gallego, Maria do Rosário Montes.

Decodificação do português $\left(L_{2}\right)$ falado por estrangeiros ingleses e americanos / Maria do Rosário Montes Gallego; orientadora Guiomar Fanganiello Calçada - São Paulo, 2008.

$344 \mathrm{f}$

Tese (Doutorado - Programa de Pós-Graduação em Filologia e Língua Portuguesa. Área de concentração: Filologia e Língua Portuguesa) - Faculdade de Filosofia, Letras e Ciências Humanas da Universidade de São Paulo.

1. Escolha lexical. 2. Nominalização. 3. Transferência. 4. Interferência.

5. Análise de erro.

CDD ou Cdu. 
GALLEGO, Maria do Rosário Montes

Decodificação do português $\left(L_{2}\right)$ falado por estrangeiros ingleses e americanos

Tese apresentada à Faculdade de Filosofia, Letras e Ciências Humanas da Universidade de São Paulo para obtenção do título de Doutor em Letras

Área de Concentração em Filologia e Língua Portuguesa.

Aprovada em:

Banca Examinadora

Prof. Dr

Instituição:

Assinatura:

Prof. Dr

Instituição:

Assinatura:

Prof. Dr

Instituição:

Assinatura:

Prof. Dr

Instituição:

Assinatura:

Prof. Dr

Instituição:

Assinatura: 
Aonerfilhm artoArtoio

À nenóia cenirta nãe, R cária Gäl@g M otes eceneu pai, M ig中

MotesMatirs 
Agradecimentos

A Prof ${ }^{a}$. Drạ. Guiomar Fanganiello Calçada, minha orientadora, pela atenção e colaboração.

À Prof ${ }^{a}$. Dra‥ leda Maria Alves pelo aproveitamento dos estudos lexicográficos.

Ao Consulado Inglês, Consulado Americano e Conselho Britânico pela concessão das entrevistas realizadas. 


\section{RESUMO}

GALLEGO, M. R. Decodificação do português $\left(L_{2}\right)$ falado por estrangeiros ingleses e americanos. 2008. $344 \mathrm{f}$. Tese (Doutorado) - Faculdade de Filosofia, Letras e Ciências Humanas, Universidade de São Paulo, São Paulo, 2008.

Nesta tese, avaliam-se as dificuldades de uso das nomonalizações em português segunda língua $\left(L_{2}\right)$ expressas por estrangeiros falantes do inglês $\left(L_{1}\right)$ e suas devidas implicações nas áreas de Morfologia, Sintaxe e Semântica. Nela apresentase a teoria da análise contrastiva $(A C)$ e cria-se uma tabela de correspondências entre a interlíngua (I) e a língua portuguesa $\left(\mathrm{L}_{2}\right)$, considerando os errors e mistakes devidos aos fenômenos da transferência e interferência através do método indutivo. Para tanto, tomaram-se por apoio os conceitos teóricos de transferência, interferência, erro e norma, entre outros. O trabalho apresenta-se dividido em duas partes: uma teórica, a análise contrastiva a priori, em que se estabelecem semelhanças e diferenças entre 0 inglês e o português: outra prática, a análise contrastiva a posteriori, em que se estudam as formas correspondentes da interlíngua (I) e da $L_{2}$ detectando as razões das falhas e suas possíveis causas Comprovados os problemas das nominalizações, acrescentam-se, ao final da tese, algumas sugestões pedagógicas, com vistas ao ensino-aprendizagem de português para estrangeiros.

Palavras-chave: Escolha lexical. Nominalização. Transferência. Interferência. Análise do erro. 


\section{ABSTRACT}

GALLEGO, M. R. Decodification of Portuguese $\left(L_{2}\right)$ spoken by English and American foreigners. 2008. $344 \mathrm{f}$. Thesis (Doutoral) - Faculdade de Filosofia, Letras e Ciências Humanas, Universidade de São Paulo, São Paulo, 2008.

In this thesis, the difficulties related to the use of Portuguese nominalizations, expressed by English-speaking foreigners, are evalued considering the respective areas of Morphology, Syntax and Semantics. First a Contrastive Analysis (CA) theory is presented and afterwards a table of correspondences between Interlanguage (I) and Portuguese $\left(\mathrm{L}_{2}\right)$ is created, taking into account the presence of mistakes and errors due to the transference and interference phenomena by means of an inductive process. Consequently it was based on the theoretical concepts of transference, interference and norm, among others. The work is divided into two parts: a theoretical one which is established by a contrastive analysis a priori discussing the similarities and main differences between English and Portuguese. Then, comes other part - a practical one where the corresponding forms of the Interlanguage and $\mathrm{L}_{2}$ ) are studied and followed by the inferences of failures and probable reasons underlying them. After confirming the nominalization problems, some pedagogical suggestions were added to facilitate the Learning of Portuguese as a second language.

Keywords: Lexical choice. Nominalization. Transference. Interference. Error analysis. 


\section{LISTA DE QUADROS}

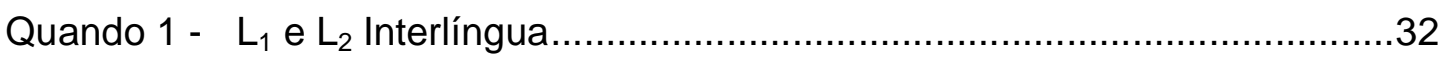

Quadro 2 - Fases da investigação dos erros .............................................

Quadro 3 - Processos de nominalização .......................................................49

Quadro 4 - Relações verbo (infinitivo) e deverbais........................................178 


\section{LISTA DE FIGURA}

Figura 1 - Processo de conceitualização ..................................................26 
SIGLAS E ABREVIATURAS

$\begin{array}{ll}\text { AC } & \text { Análise contrastiva } \\ \text { adj } & \text { adjetivo } \\ \text { art } & \text { artigo } \\ \text { def } & \text { definido } \\ \text { det } & \text { determinante } \\ \text { I } & \text { interlíngua } \\ \text { Inf } & \text { infinitivo } \\ \mathrm{L}_{1} & \text { língua materna - inglês } \\ \mathrm{L}_{2} & \text { língua portuguesa segunda língua } \\ \mathrm{L}_{3} & \text { língua portuguesa terceira língua } \\ \text { mod } & \text { modificador } \\ \mathrm{N} & \text { nome } \\ \text { prep } & \text { preposição } \\ \text { subord } & \text { subordinada } \\ \text { subst } & \text { substantivo }\end{array}$




\section{SUMÁRIO}

INTRODUÇÃO

CAPÍTULO 1: PROCEDIMENTOS TEÓRICO-METODOLÓGICOS .....................24

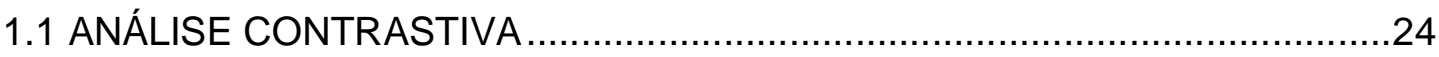

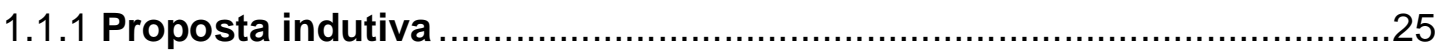

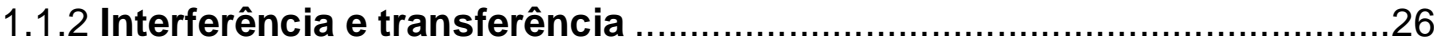

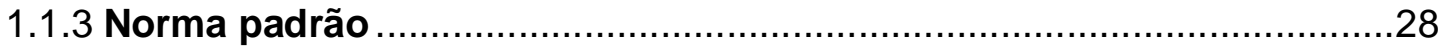

1.1.4 Erro

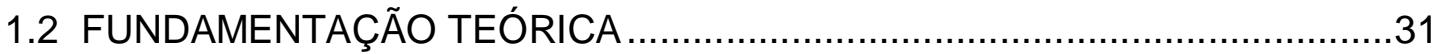

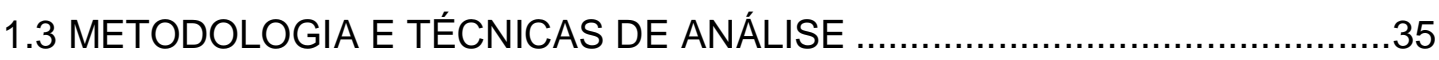

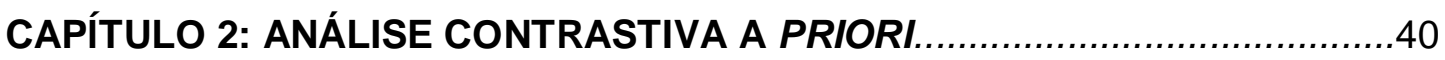

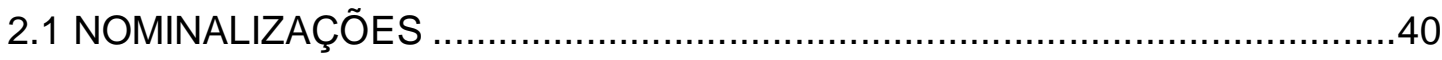

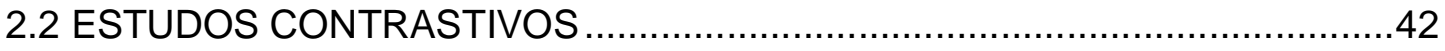




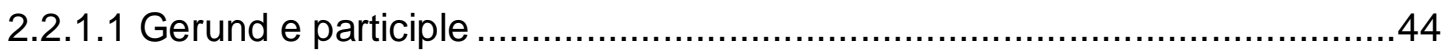

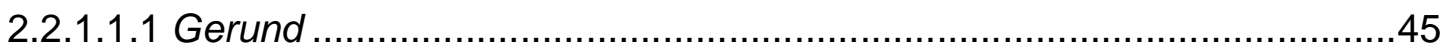

2.2.1.1.2 Participle: present e past construtions.......................................... 47

2.2.1.2 Paralelo contrastivo do -ing: inferências e hipótese ........................... 51

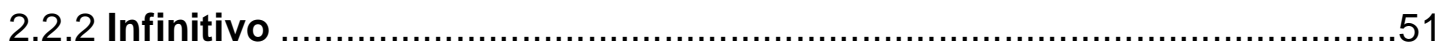

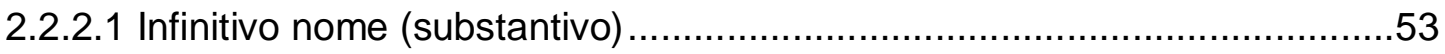

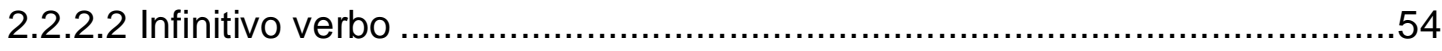

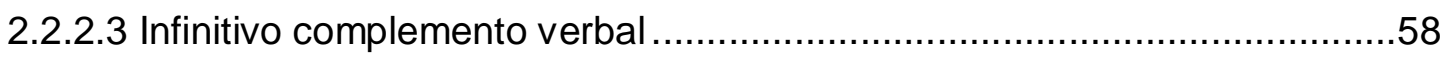

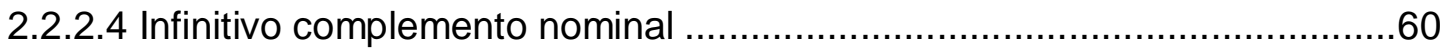

2.2.2.5 Infinitivo outras possibilidades de ocorrência ....................................61

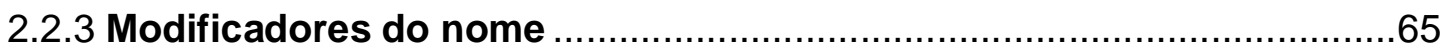

2.2.3.1 Modificadores do nome: casos específicos ......................................72

2.2.3.2 Modificador: de+substantivo ............................................................. 73

2.2.3.3 Modificador secundário: particípio ................................................73

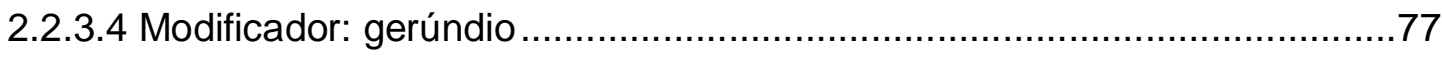

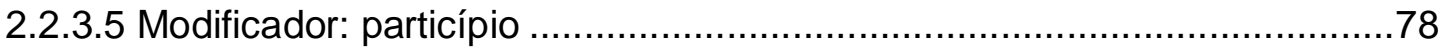

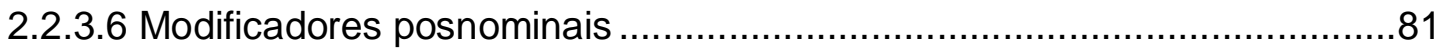

2.2.3.7 Modificadores: palavras invariáveis ............................................... 83 
2.2.3.8 Modificadores: formas have e be 84

2.2.3.9 Modificadores: transitivos e intransitivos ............................................. 85

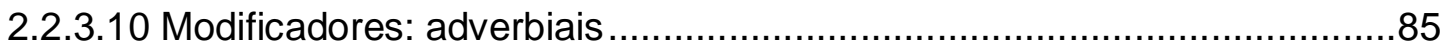

2.2.3.11 Modificadores: derivados de nomes (substantivos) ............................. 86

2.2.3.12 Modificador: numeral + substantivo no singular ............................... 87

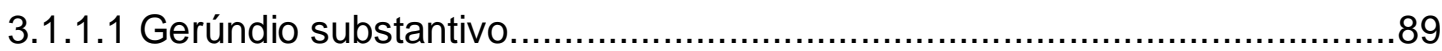

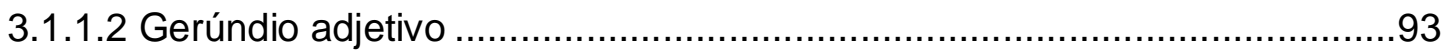

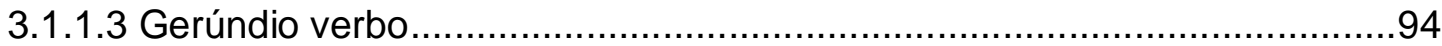

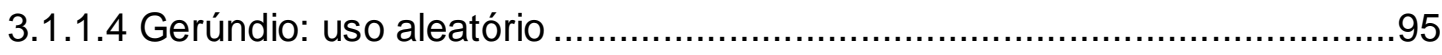

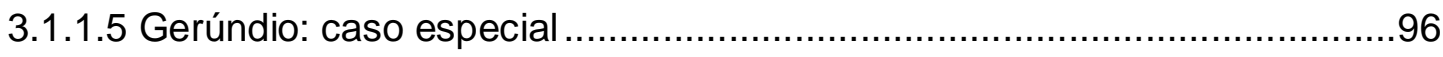

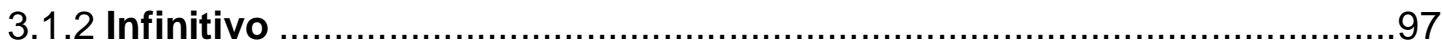

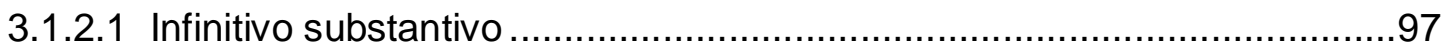

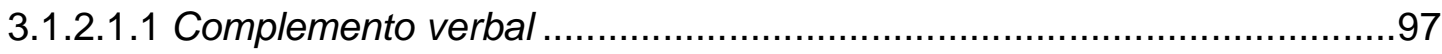




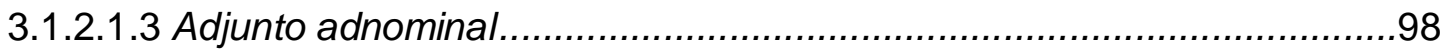

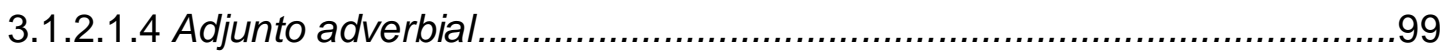

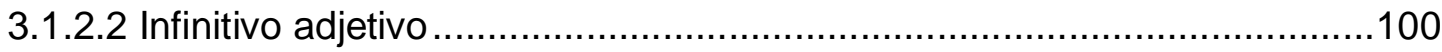

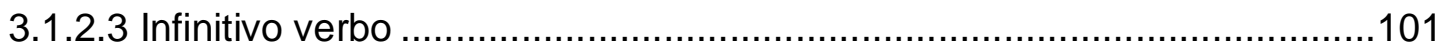

3.1.2.3.1 Modo indicativo: tempos simples ..................................................101

3.1.2.3.1.1 Período simples (oração absoluta) ……..........................................102

3.1.2.3.1.2 Período composto (oração coordenada e subordinada)....................103

3.1.2.3.1.3 Tempos simples: caso especial..................................................104

3.1.2.3.2 Modo indicativo: tempos compostos............................................105

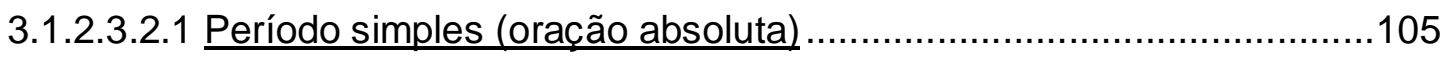

3.1.2.3.2.2 Período composto (oração subordinada) …...................................106

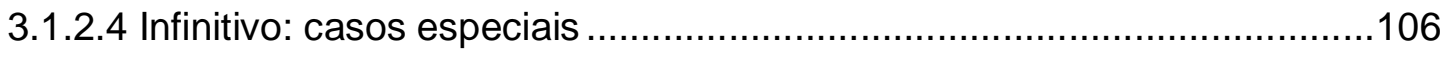

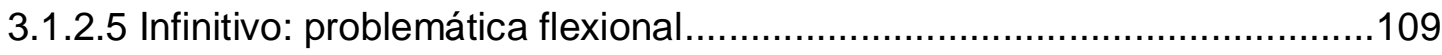

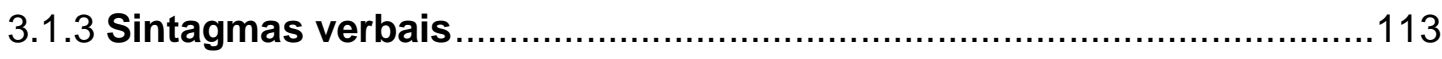

3.1.3.1 Sintagmas com dois componentes ...................................................113

3.1.3.2 Sintagmas com três componentes ......................................................122

3.1.4 Sintagmas nominais e sintagmas adjetivais …..............................126

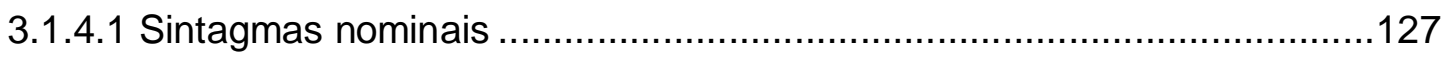


3.1.4.1.1 Elos

3.1.4.1.2 Modificadores ...................................................................... 134

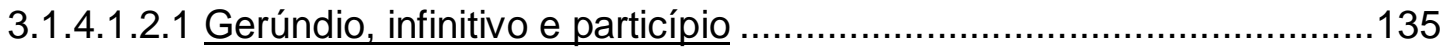

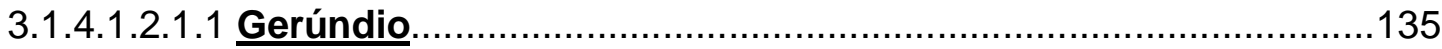

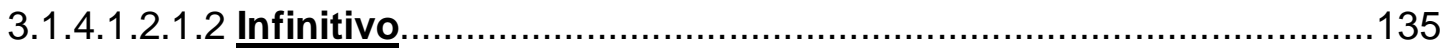

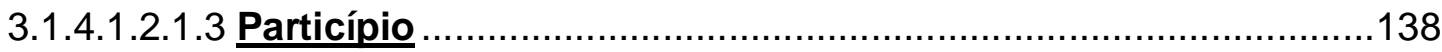

3.1.4.1.2.2 Criacões morfossintático-lexicais improcedentes ............................139

3.1.4.1.2.3 Seqüência ilógica e insuficência nos componentes referenciais ........140

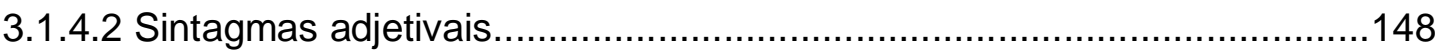

3.1.5 Classes de palavras: usos e inter-relações ....................................150

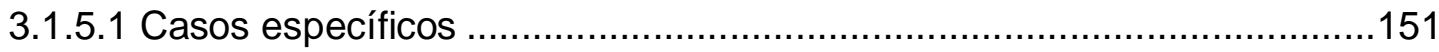

3.1.5.1.1 Ampliação................................................................... 151

3.1.5.1.2 Redução .......................................................................... 153

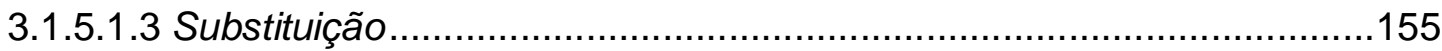

3.1.5.1.4 Complementação ................................................................ 155

3.1.5.1.5 Generalização .................................................................... 156

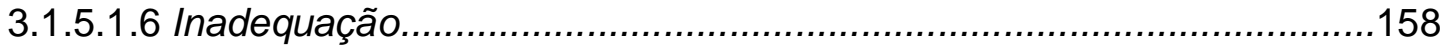

3.1.6 Nominalizações: improcedências ....................................................... 160

3.1.6.1 Nomes: formação dos substantivos............................................160 
3.1.6.1.1 Derivação sufixal.

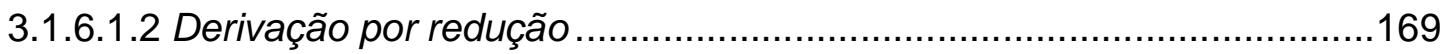

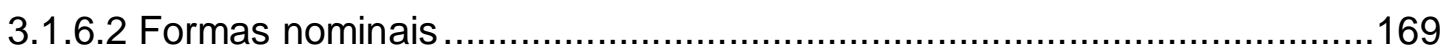

3.1.6.3 Formas moninalizadas: derivação regressiva ......................................174

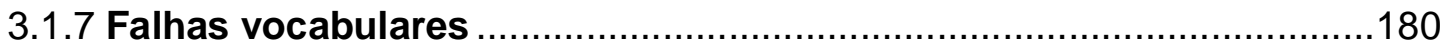

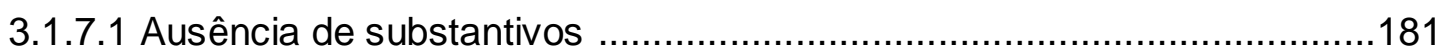

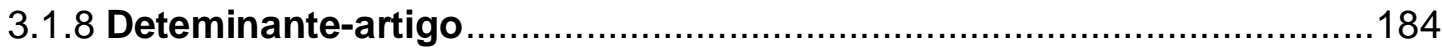

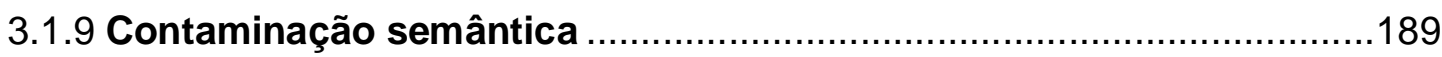

3.1.9.1 Grupo A: relações semânticas próximas ..............................................190

3.1.9.2 Grupo B: relações sêmicas remotas...................................................194

3.1.10 Classes de palavras: entrelaçamentos...........................................198

3.1.10.1 Entrelaçamentos lexicais: palavras de diferentes classes ....................198

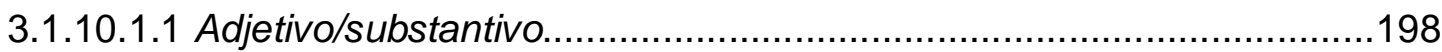

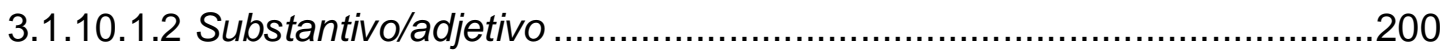

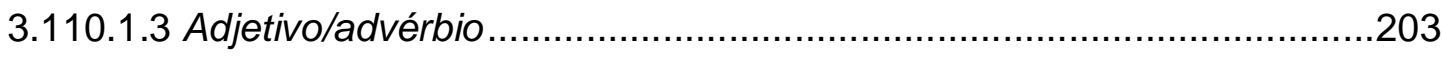

3.1.10.1.4 Advérbio / adjetivo / substantivo.......................................................205

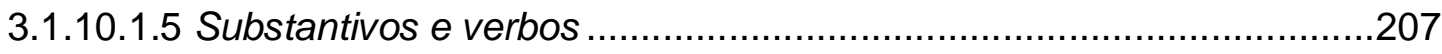

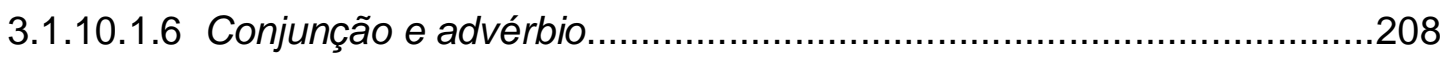

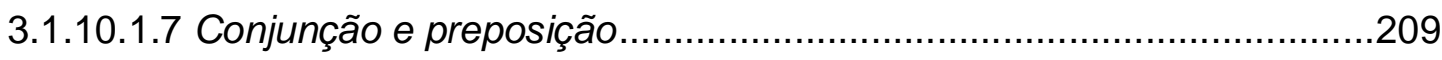


3.1.10.1.8 Advérbio e indefinido 209

3.1.10.1.9 Formas nominais: entrelaçamentos extensivos a outras classes de palavras. 210

3.1.10.1.9.1 Deverbal e infinitivo 210

3.1.10.1.9.2 Infinitivo e deverbal. 211

3.1.10.1.9.3 Infinitivo e gerúndio 211

3.1.10.1.9.4 Gerúndio e infinitivo 212

3.1.10.1.9.5 Gerúndio e particípio 212

3.1.10.1.9.6 Gerúndio e deverbal 212

3.1.10.1.9.7 Locução prepositiva e gerúndio. 213

3.1,10.1.9.8 Infinitivo e substantivo .213

3.1.10.1.9.9 Infinitivo e adjetivo. .214

3.1.10.1.9.10 Infinitivo e particípio .214

3.1.10.1.9.11 Infinitivo verbo e infinitivo nominalizado. 215

3.1.10.2 Entrelaçamentos lexicais: palavras da mesma classe. 215

3.1.10.2.1 Advérbio: problema morfológico e semântico .215

3.1.10.2.2 Adjetivo: problema morfológico, semântico e morfossemântico 218

3.1.10.3 Instrumentos gramaticais 223

3.1.10.3.1 Conjunção . .223 


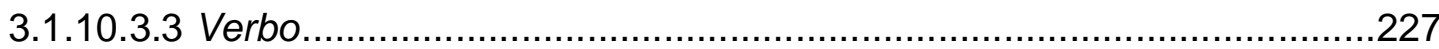

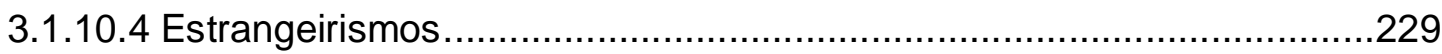

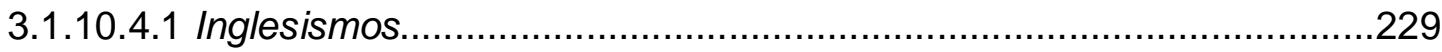

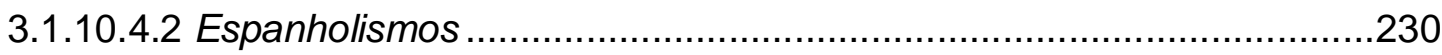

4 CONCLUSÃO

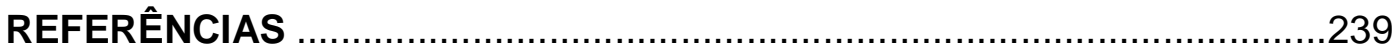

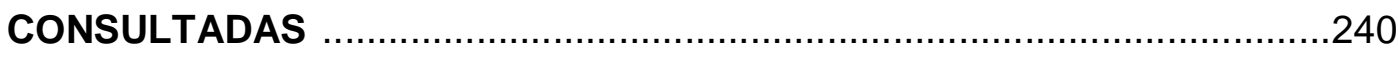

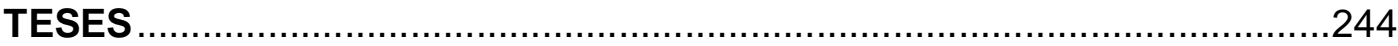

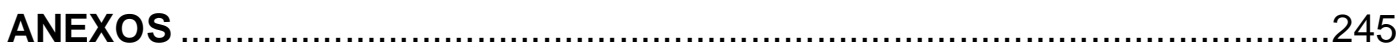

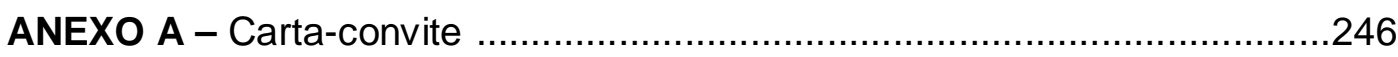

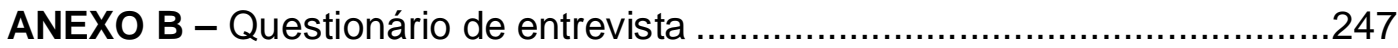

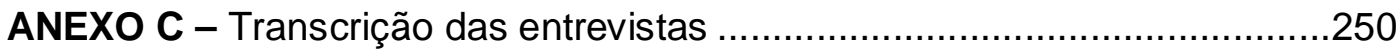

ANEXO D - Tabela De Correspondências (interlíngua e língua 2)..................293

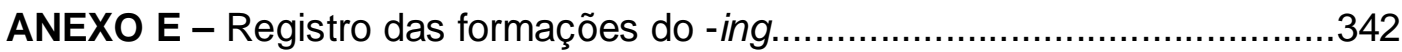

ANEXO F - Registro das posições do -ing ..................................................343

ANEXO G - Registro das combinações do -ing................................................344

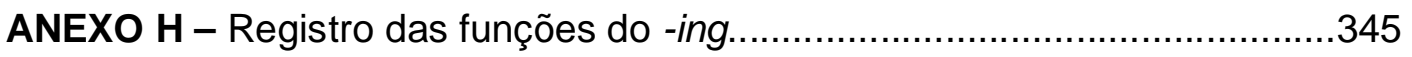




\section{INTRODUÇÃO}

Esta tese consiste numa continuidade do trabalho previamente proposto na Dissertação de Mestrado ${ }^{1}$, qual seja, registrar e discutir as causas das maiores dificuldades enfrentadas pelos falantes da língua inglesa que tenham português $\left(L_{1}\right)$ como segunda $\left(L_{2}\right)$ ou terceira língua $\left(L_{3}\right)$. Considerando o papel da interferência da língua inglesa na aprendizagem da língua portuguesa, uma vez que esta não tem um modelo único de língua como o tem a língua inglesa (Serafini, 1987), iniciamos nossa pesquisa interessados em investigar o comportamento lingüístico dos falantes ingleses de $L_{2}$, com o objetivo de detectar as possíveis dificuldades, determinadas pela ação da interferência. Para tanto, optamos pela técnica de entrevistas, a fim de estabelecer um corpus adequado a tal fim.

O universo das dificuldades reveladas pelas entrevistas evidenciou a impossibilidade de manipulação da totalidade dos dados obtidos. Diante do volume do material e da diversidade dos problemas, estabelecemos para a etapa do Mestrado um subcorpus, restringindo nosso estudo à classe dos substantivos, baseados na análise contrastiva $(A C)$ entre as duas línguas: o inglês e o português. Quanto às demais classes de palavras, reservamos nossa atenção para uma etapa posterior, o que justifica a continuidade de nosso trabalho nesta Tese de Doutorado.

Nesta etapa, um outro subcorpus a partir do mesmo corpus inicial foi criado para um novo levantamento do material relativo às classes palavras em geral, tendo em vista a ampliação e aprofundamento dos assuntos limitados à Monografia do Mestrado. Estabelecido esse subcorpus, doravante corpus do atual estudo, partimos para a organização e desenvolvimento deste trabalho.

Com vistas à aplicação de um raciocínio lógico, no decorrer desta exposição, optamos por sua divisão em duas partes: uma análise contrastiva a priori e outra, a posteriori, cada uma com sua metodologia especifica, exposta nas respectivas partes. Recorremos a esse procedimento para estabelecer uma estrutura

\footnotetext{
${ }^{1}$ GALLEGO, M. DO R. A interlíngua na fala de adultos e jovens aprendizes da língua portuguesa. 2002. $177 f$. Dissertação de Mestrado em Letras - Faculdade de Filosofia, Letras e Ciências Humanas. Universidade de São Paulo, São Paulo, 2002.
} 
compatível e, portanto, facilitadora da compreensão das idéias fundamentais em todo o desenvolvimento do assunto.

No estudo a priori, destinado ao embasamento teórico deste trabalho, lançamos mão da análise contrastiva (AC), comparando as duas linguas - inglês e português numa fase anterior à investigação da fala dos entrevistados. Nesse caso alcançamos somente uma visão hipotético-dedutiva de dificuldades na segunda língua, pois caminhamos da teoria aos fatos. Consideramos então o erro como simples hipótese, apenas uma suposição. Nessa visão hipotética, tivemos sempre em vista, em cada uma das línguas, o estudo das classes de palavras, o contexto, como determinante dessas classes, bem como o comportamento e o intercâmbio delas.

Quanto à análise contrastiva a posteriori, que consiste na análise do material coletado, dela faremos uso pelo fato de ela expor uma visão indutiva das dificuldades verificadas e justificadas muitas vezes pelas divergências em ambas as línguas uma vez que esta caminha dos fatos à teoria, pois exibe o erro detectado, que é real neste caso. Questionávamos, entretanto, se a apropriada seleção lexical seria responsável pela efetiva decodificação da fala dos estrangeiros.

Por termos adotado a análise contrastiva como recurso norteador de nossas inferências, limitamos a parte, relativa ao estudo a priori, ao estabelecimento das semelhanças e das diferenças entre as línguas inglesa e portuguesa, a fim de procedermos à verificação de nossa hipótese sobre as prováveis interferências e conseqüentes dificuldades dos entrevistados - uma relação de variáveis responsáveis pelos transtornos enfrentados pelos falantes de português como língua estrangeira. Este segmento da tese consta de três capítulos; no primeiro, substantivos em -ing e suas correspondências em português, nosso estudo originase de uma única forma, o -ing form inglês, para uma grande variedade de derivações sufixais em português, no segundo capítulo, a análise contrastiva entre os infinitivos, aplica-se um sentido inverso em relação às línguas de partida e de chegada; caminha-se, do português para suas correspondências em inglês e no terceiro capítulo, os modificadores do nome, apresentamos variantes estruturais em inglês e português. Nesses capítulos abordamos os assuntos que monitoraram nossa pesquisa. Neles, com vistas ao objetivo deste trabalho, apresentamos referências que viabilizaram hipóteses sobre as dificuldades. Tiveram como meta a ampliação e o aprofundamento das inferências estabelecidas na Dissertação de Mestrado, uma 
preocupação com os nomes, com as formas nominais do verbo (infinitivo, gerúndio e particípio) e as formas nominalizadas (deverbais), temas que requerem nossa concentração neste trabalho.

Para a elaboração desta tese realizamos uma releitura das obras pesquisadas por ocasião da nossa Dissertação de Mestrado, cujos assuntos se apresentam relacionados à análise contrastiva. Essas leituras concorreram para nossos insights, fornecendo-nos subsídios ao levantamento da hipótese de que toda diferença supõe e seria responsável por uma dificuldade.

Com base nessas experiências passamos à elaboração e organização dos capítulos de referência nos quais recorremos à análise contrastiva enquanto ferramenta lingüística confiável.

Quanto ao grau de influência que tiveram as dificuldades apresentadas pelos entrevistados, impedindo-Ihes a emissão da verdadeira intenção de suas falas, para que se procedesse à decodificação de suas mensagens, baseamo-nos nos conceitos de transferência, interferência, erro e norma.

No que se refere à interferência, podemos observá-la de diferentes pontos de vista além do pedagógico, quais sejam: o psicológico, segundo Debyser (1970); o lingüístico, de acordo com Mackey (1965).

Ainda relacionado à interferência, tendo em vista as várias definições formuladas em situações de bilingüismo, deve-se considerar também o conceito de Weinreich (1968), comentado mais adiante na página 25.

Como nosso estudo concentrou-se no mecanismo interferencial de um ponto de vista exclusivamente lingüístico, buscamos apoio no modelo de Pottier (1972) que pressupõe um nível conceptual anterior ao lingüístico - pensar na língua-alvo é um meio de evitar interferências

Quanto ao erro, tomamos por base os conceitos de Debyser (1970), Burt e Dulay (1974), Burt e Kiparsky (1972) e Corder (1974). De acordo com este último teórico estabelecemos os erros sistemáticos e os não sistemáticos.

Para o conceito de norma, uma noção prioritária à consideração dos desvios - erros - optamos por seguir Coseriu (1969) e estabelecemos como norma da língua de chegada, o português - aquela encontrada na fala de pessoas já graduadas, pós-graduadas ou com função diplomática: a norma culta.

Consideradas as várias opiniões envolvendo as diferentes concepções de erro e preocupados com as dificuldades dos falantes da segunda língua, ainda em 
nível de probabilidade e suposição, procedemos a uma análise minuciosa dos erros, com vistas à confirmação de nossas hipóteses, para saber onde recaem as maiores dificuldades dos falantes ao aprenderem português como segunda língua. Iniciamos então a parte prática de nosso trabalho, referida como a posteriori.

Nesta etapa, consideramos a interlíngua (mistura de duas línguas) como base de investigação e análise sempre relacionada à sua correspondência em $\mathrm{L}_{2}$ língua portuguesa. Separamos os registros, visando à criação de um subcorpus, de acordo com as classes de palavras: substantivos, adjetivos, verbos e advérbios. No que se refere à classe das preposições e das conjunções, incluímo-las sob o título de construções. Buscamos assim uma maneira didática e funcional na avaliação das falhas. Essa parte do trabalho, responsável pelo universo de erros reais, foi resultante de um mecanismo prático que funcionou como condutor natural de nossa investigação, diante do objetivo da tese: avaliar a escolha lexical e suas implicações com as respectivas áreas lingüísticas: morfologia, sintaxe e semântica - um exercício constante para localização e avaliação dos erros, muitas vezes originários da não-correspondência entre as línguas os quais impediam a adequada decodificação das mensagens. Para isso adotamos, como meio de argumentação segura, as falas registradas, comentários sobre as causas atribuídas à ação da interferência; recorrendo à lógica existente nas duas línguas, lógica esta estabelecida pelo comportamento das palavras em suas funções contextuais e discursivas.

Para a organização de um banco de dados dos respectivos erros dos entrevistados, com utilidade prática e pedagógica, criamos uma relação com os seguintes temas: uso do gerúndio, do infinitivo, sintagmas verbais, sintagmas nominais, recursos alternativos em geral, inferência das dificuldades, recursos alternativos para as formas nominais e nominalizadas, lacunas sintáticas, uso de determinantes, inadequação lexical, inadequação nas relações morfossintáticosemânticas, inglesismos e espanholismos.

Essa relação inclui os assuntos de nosso interesse trazendo à tona os resultados que refletem os problemas enfrentados pelos falantes. 


\section{CAPÍTULO 1: PROCEDIMENTOS TEÓRICO-METODOLÓGICOS}

Dada a importância da AC para a consecução deste trabalho, julgamos pertinente tecer alguns comentários a respeito dessa técnica de análise e justificar nossa escolha metodológica.

Focalizaremos então a AC, a proposta indutiva, os conceitos de interferência e transferência, de norma padrão e de erro, para depois abrir espaço para a fundamentação teórica e para os métodos e técnicas de análise por nós utilizados.

\subsection{ANÁLISE CONTRASTIVA}

A análise contrastiva entre a língua materna $\left(L_{1}\right)$ e a língua estrangeira $\left(L_{2}\right)$ tornou-se um tipo de enfoque dos problemas lingüísticos que tem merecido interesse e atenção dos estudiosos da aprendizagem de uma segunda língua $\left(L_{2}\right)$. Por esse motivo, encontram-se, atualmente, inúmeras obras sobre a AC que abordam diferentes níveis lingüísticos, quais sejam: o morfológico, o sintático e o semântico.

Nesses estudos, uns mais pretensiosos; outros, menos, encontram-se muitos contrastes morfológicos e sintáticos; porém, verificam-se pesquisas insuficientes no que se refere aos aspectos semânticos. Isso talvez se justifique, em parte, pela pouca importância que o modelo encontrado na lingüística descritiva atribui aos trabalhos contrastivos. Tais estudos, contudo, apresentam inumeráveis sugestões para o ensino de uma $L_{2}$ e nos encaminham para maior concentração nos aspectos relativos a esses diferentes níveis. Daí nossa opção pela AC para a análise de nosso material.

Todavia, não podemos ignorar a existência de insatisfações em relação à AC, as quais podem ser atribuídas ao fato de não encontrarmos em seus estudos uma visão mais pragmática dos erros nela presentes, uma vez que esses erros nem sempre coincidem com aqueles cometidos pelos falantes e aprendizes de uma nova língua, o que nos leva a entender que toda potencialidade de hábitos, atitudes e erros encontrada na manifestação desses falantes nem sempre é passível de 
previsão pela AC. Esse fator alia-se ao prestígio cada vez mais crescente da teoria gerativo-transformacional, apoiada em uma psicologia mentalista, que vê a aprendizagem de línguas como um processo cognitivo do qual o estudante tem consciência e não mero condicionamento, como propõem os behavioristas.

Cabe esclarecer que não queremos dizer que a convincência e a viabilidade asseguradas pelas propostas da teoria gerativa representem uma incompatibilidade com os estudos contrastivos. O descritivista Lado (1966), ao avaliar este assunto, reconhece de início que a proposta gerativa lança novas luzes acerca dos estudos contrastivos.

Como, porém, a maioria dessa produção da AC se encontra apoiada em modelos estruturalistas, começam a surgir opiniões mais pertinentes e funcionais à adequada assimilação de uma nova língua, acabando por enriquecê-la.

A proposta inferida da $\mathrm{AC}$ é contrastar um ou mais aspectos teóricos, nas duas línguas, em nosso caso o inglês e o português, para depois verificar até que ponto essas previsões são válidas, caracterizada, portanto, como proposta dedutiva.

Independentemente do modelo utilizado nos estudos contrastivos, é fundamental observar a abordagem adotada por alguns teóricos. Jensen (1975), por exemplo, reconhece que a AC tem um valor relativo por seu caráter hipotéticodedutivo devendo ser complementada por investigação e análise de erros mais próprios, diretamente ligados aos fatos. Não deve, pois, ficar somente assentada e respaldada por meras hipóteses. Surge então a idéia de investigarmos os mecanismos subjacentes aos erros atribuídos à interferências, detectados a partir da fala dos entrevistados, utilizando-nos do método indutivo.

\subsubsection{Proposta indutiva}

Com base na leitura de obras acerca da AC e em nossa experiência didática no ensino de inglês e português, - sem com isso pretender insinuar que haja incompatibilidade entre gerativistas e estruturalistas - partimos do princípio de que a simples correção do incontrolável número de erros cometidos pelos falantes e 
aprendizes não seja satisfatória. Reforça-se assim a idéia preliminar da necessidade de investigar os mecanismos subjacentes a tais erros.

Por esse motivo, neste trabalho optamos pelo caminho inverso ao da proposta dedutiva: o procedimento indutivo - dos fatos à teoria - por nos parecer mais viável, econômico e funcional metodologicamente, em vista do papel da interferência no mecanismo da produção de erros durante a aprendizagem e uso de uma segunda língua, o português. Ressalte-se que o papel da interferência nunca nos levantou dúvidas, pois aceitamos a posição de Debyser (1970, p. 31) segundo a qual, quando se aprende uma língua estrangeira, "apesar dos esforços didáticopedagógicos dos professores, uma intenção incontrolável e inconsciente do aprendiz, isto é, uma tendência e mesmo o desejo de se exprimir na língua materna está sempre presente."

Optamos por partir das inadequações registradas por meio das entrevistas para em seguida analisá-las, mas sempre de uma perspectiva contrastiva, sem perder de vista a língua materna. A análise contrastiva, nesse caso, não é usada para detectar hipóteses a respeito das possíveis inadequações, mas para pesquisar e analisar o que está por trás delas, investigando-lhes os mecanismos subjacentes que as justifiquem para, numa etapa posterior, buscar alternativas metodológicas que permitam evitá-las. Para tanto, consideramos fundamentais os conceitos de interferência e transferência, norma e erro, expostos a seguir.

\subsubsection{Interferência e transferência}

Lembramos inicialmente que a interferência pode ser conceituada de vários pontos de vista, a saber: o psicológico, o lingüístico e o pedagógico. Do ponto de vista psicológico, ela é considerada uma contaminação de comportamento (DEBYSER, 1970). Esse autor ainda acrescenta que se trata de um efeito negativo de um hábito sobre a aprendizagem de um outro. Do ponto de vista lingüístico, tratase do uso de elementos de uma língua enquanto falamos ou escrevemos uma outra (Mackey, 1965). Do ponto de vista pedagógico, segundo Wagner (1970, p. 47), a interferência lingüística é "um tipo particular de erro cometido por um aluno de 
determinada língua estrangeira, sob o efeito de hábitos ou estruturas da língua materna, que correspondem à maneira e às formas adquiridas por ele durante a assimilação de sua primeira língua." De acordo com Pottier (1972), o aprendiz foi educado para pensar de uma maneira que ele, agora, que transferir para a língua estrangeira.

No que diz respeito à interferência e à transferência, Wagner (1970, p. 47) apresenta uma distinção entre ambas. Segundo esse teórico, "chamar-se-á transferência o efeito positivo de uma aprendizagem sobre outra: interferência, o efeito negativo."

Apesar de reconhecermos a procedência e validade dessas definições de transferência e interferência sob os vários pontos de vista e de sabermos que são utilizadas operacionalmente, não consideramos os processos interferenciais como únicos responsáveis pela produção de erros na aprendizagem de uma segunda língua. Todas essas referências, ao que tudo indica, era uma preocupação constante encontrada na Psicologia do Condicionamento, que adotava como parâmetros tais conceitos. Queremos esclarecer, contudo, que não somos adeptos totais da teoria behaviorista da aquisição da linguagem pelo fato de a considerarmos associada à assimilação inconsciente da linguagem; a teoria cognitivista parece-nos mais convincente por estar sempre relacionada com a assimilação consciente da linguagem, assegurando, portanto, a compreensão e retenção das regras da língua.

Não podemos deixar de observar, entretanto, que muitas definições de interferência de que dispomos foram formuladas tendo em vista situações de bilingüismo. É o caso, segundo Weinreich (1968), de a interferência vista como desvios de normas de qualquer uma das línguas que ocorrem na fala dos bilingües, como resultado de sua familiaridade com mais de uma língua, em contato .

Enfatizamos que as características do fenômeno interferência em situações de bilingüismo diferem, obviamente, das inferências observadas em situações de aprendizagem de uma segunda língua, em que a influência da língua nativa se faz sentir a todo instante.

Como nosso estudo se concentrou no mecanismo interferencial de um ponto de vista exclusivamente lingüístico, buscamos apoio no modelo de Pottier (1972), conforme mencionado na introdução deste trabalho.

Segundo esse autor, existe um nível conceptual anterior ao lingüístico. Se um indivíduo nativo de $L_{1}$ quiser emitir uma mensagem em $L_{2}$, essa mensagem terá de 
percorrer o seguinte caminho: do conceitual ao lingüístico $\left(L_{1}\right)$ e, somente depois dessa primeira etapa a mensagem será traduzida para $L_{2}$. Observa-se que os dois processos operam no mesmo indivíduo, o omasiológico - processo do emissor - e o semasiológico, processo do receptor: da mensagem à conceptualização.

Visualizemos o processo de concitualização na figura 1;

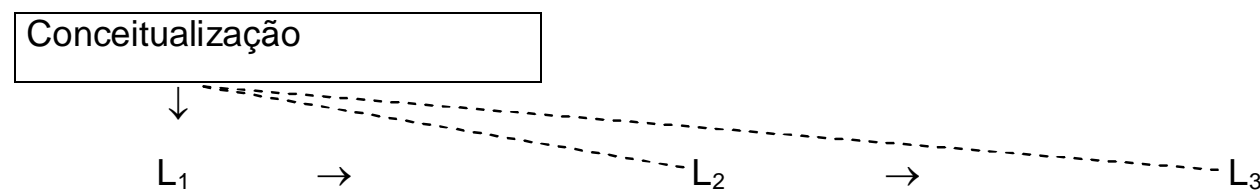

(o aprendiz pensa primeiro na língua materna ou na anterior)

Legenda: $\rightarrow$ caminho percorrido pela mensagem.

---- caminho que a mensagem deve percorrer para que a interferência seja evitada. (pensar na língua estrangeira $\rightarrow$ língua de chegada).

Figura 1 - Processo de conceitualização

Como se pode verificar, não há uma passagem direta do nível conceptual para $L_{2}$. A passagem por $L_{1}$ e sua conversão é responsável pelos fenômenos interferenciais. Toda compartimentalização já feita em $\mathrm{L}_{1}{ }^{2}$ difere necessariamente dos recortes da realidade utilizados em $L_{2}$ e será passível de influenciar essa passagem de $L_{1}$ a $L_{2}$, ocasionando a presença de erros.

\subsubsection{Norma padrão}

A noção de norma apresenta-se prioritária para estabelecermos o que são desvios, erros. Segundo o lingüista Coseriu (1969, p. 52), norma é o "conjunto de realizações lingüísticas constantes e repetidas, de caráter sociocultural e

\footnotetext{
${ }^{2}$ Segundo Martinet (1970), cada povo recorta os dados da realidade de uma maneira característica. Esse recorte varia de povo para povo." In: Elementos de Lingüística Geral. p. 3
} 
dependente de vários fatores operantes na comunidade idiomática." Com base nessa definição determinamos a norma da língua de chegada, o português. Essa norma padrão estabelecida oficialmente foi, então, a encontrada na fala de pessoas já graduadas, pós-graduadas ou com função política ou diplomática: a norma culta, que será o nosso parâmetro, conforme mencionado. Contudo, quanto aos parâmetros funcionais necessários à conceituação de erro, é preciso considerar o envolvimento de uma série de variáveis, conforme veremos a seguir.

\subsubsection{Erro}

Existem muitas opiniões acerca do erro. Entre elas a de que a aprendizagem de uma língua estrangeira permite algumas afinidades com a língua materna, apresentando-se como uma série de estruturações e reestruturações sucessivas, em que os erros passam a ser vistos como inevitáveis e até mesmo necessários na organização progressiva da competência lingüística do aprendiz. O erro, portanto, não é algo visto como existente apenas na aprendizagem de uma segunda língua.

Assegura Debyser (1970, p. 31) que "o erro, considerado até o momento como um indesejável e inevitável acidente de aprendizagem, tornar-se-ia, assim, um momento dialético inevitável e funcional."

Consideremos ainda as definições de erro que seguem:

De acordo com Burt e Dulay (1974, p. 92), o erro é visto como "desvio de estruturas sintáticas que os falantes nativos adultos consideram gramaticalmente corretas".

Para Burt e Kiparsky (1972, p.150), "um erro é o que os estudantes tendem a cometer quando aprendem inglês como segunda língua $\left(L_{2}\right)$, aos quais não se atribui nenhuma culpa."

Quanto a Corder (1974) que se aproxima bastante das opiniões dos lingüistas citados, faz uma distinção bastante útil entre erros sistemáticos e não-sistemáticos, atribuindo esses a lapsos de memória, a estados físicos, como cansaço, e a condições psicológicas como emoções fortes. Os erros sistemáticos, segundo ele, constituem-se em elementos que permitem avaliar aquilo que chama de 
competência transicional do falante. Esse lingüista também acrescenta que "os erros de performance serão caracteristicamente assistemáticos e os errors de competência, sistemáticos". Denomina os primeiros de mistakes e os demais de errors (p. 30).

Essa distinção entre erros de performance e erros de competência estabelecida pelo estudioso revela-se bastante útil a sugestões e decisões metodológicas na organização de um projeto de aprendizagem de uma segunda língua, motivo pelo qual dela faremos uso na parte prática desta trabalho.

Lembramos que, à semelhança do que ocorre com a interferência, o parâmetro funcional para o estabelecimento do conceito de erro envolve uma série de variáveis, tais como as lingüísticas, as psicolingüísticas, as sociolingüísticas e as pedagógicas.

As variáveis lingüísticas consistem na transferência estrutural de uma língua em relação à outra no seu aspecto negativo, ocasionando a produção de estruturas indesejáveis, nos níveis morfossintático, semântico e lexical.

Quanto às variáveis psicolingüísticas, são decorrentes das diferenças individuais quanto à idade, QI, interesse, motivação, aptidões lingüísticas, tempo de exposição à língua, favorecendo o processo de aprendizagem.

As variáveis sociolingüísticas associam-se a aspectos socioeconômicos dos sujeitos, propiciando maior ou menor oportunidade de atividades extra-escolares relacionadas à aquisição de segunda língua $\left(L_{2}\right)$, como viagens ao exterior e cursos particulares de línguas, entre outros.

No que se refere às variáveis pedagógicas, relacionam-se a métodos e técnicas docentes e a material didático, utilizados no processo de aprendizagem os quais influenciam a redução da interferência da língua materna na segunda língua $\left(L_{2}\right)$.

Considerando a complexidade que uma abordagem tão abrangente - as lingüísticas, as psicolingüísticas, as sociolingüísticas e as pedagógicas acarretaria, dada à natureza e o objetivo de nosso trabalho, estabelecemos um corpus concentramo-nos apenas em uma discussão mais profunda dos fatores lingüísticos.

Pelo fato de termos consciência de toda a complexidade de uma abordagem abrangente, fizemos uma seleção de um grupo, constituído por falantes do inglês 
britânico e do americano, cujas falas seriam por nós estudadas sem a preocupação de correlacionar os dados de natureza sociopsico-pedagógica aos lingüísticos.

Ressaltamos que, independentemente das posições adotadas behavioristas ou mentalistas - o erro é sempre visto como um desvio em relação à norma padrão e será aqui ( numa primeira etapa) considerando enquanto mera hipótese.

\subsection{FUNDAMENTAÇÃO TEÓRICA}

Algumas reflexões a respeito das diversas possibilidades de contribuir para o desenvolvimento de habilidades necessárias à criação de uma competência comunicativa, um domínio discursivo, decorrem de nossa capacidade de utilização dos mecanismos lingüísticos ou gramaticais de nossa língua, reconhecendo como condição prioritária para uma atualização eficaz em $L_{2}$ a necessidade de se pensar nessa língua, o que significa assimilar bem um novo comportamento das palavras, na tentativa de representar adequadamente o pensamento.

Tais considerações nos remeteram diretamente às teorias de autores já citados, como Aronson (1978), que apontam os estudos da interlíngua (mistura de duas línguas) como bastante funcionais para o levantamento e compreensão das maiores dificuldades dos estrangeiros. Esse referido autor sugere que o contraste entre Interlíngua e $L_{2}$ vai permitir a compreensão das maiores interferências entre as duas línguas.

Para nós, as interferências estão intimamente relacionadas com o problema da transferência negativa, conforme veremos em AC a posteriori. Assim, entendemos por transferência aquilo que apresenta uma correspondência direta entre as duas línguas quanto à escolha lexical e quanto à combinação das palavras (sintaxe) e isso o estrangeiro, contrariamente ao que propõem os autores Aronson (1978) e Krashen (1981), até pode adquirir através de consultas a dicionários e 
glossários e de recursos próprios conseguidos pela observação, acompanhamento e convivência com a fala.

Quanto à interferência, no entanto, tem de ser aprendida. O professor deverá ensinar o aluno a pensar na idéia e na representação dela através de palavras e de suas combinações mais básicas e necessárias a uma comunicação satisfatória.

Ainda de acordo com Aronson (1978), no trabalho com alunos adultos, com suficiente maturidade gramatical, pode-se usar abertamente a análise contrastiva nas aulas de $L_{2}$, desde que esses estudantes revelem capacidade para entender as comparações que estão sendo feitas.

Muitos lingüistas parecem defender o ponto de vista dos cognitivistas de que a aprendizagem nova é determinada pelo que já é conhecido. Podemos inferir daí que qualquer explicação ou aprendizagem da língua-alvo não deve se limitar aos contrastes e semelhanças entre $L_{1}$ e $L_{2}$, pois existe a possibilidade de se usar, como estratégia de ensino, o relacionamento dos dados novos desta língua-alvo com aqueles de outras línguas já conhecidas pelo estudante, isto é, o desenvolvimento de uma competência lingüística deverá acontecer através da reutilização dos processos da sua $L_{1}$, acrescidos àqueles processos cognitivos já existentes.

Já, segundo Coseriu (1969, p. 52) "os falantes utilizam para a expressão das suas intuições inéditas, modelos, formas ideais que eles encontram na sua "língua anterior".

Podemos observar que o indivíduo cria sua expressão, realiza concretamente em seu falar estruturas e formas existentes em sua aprendizagem anterior (uma $L_{2}$ ) ou em um falar adquirido (língua materna).

Recorrermos aos atos lingüísticos devidamente registrados no próprio momento de sua produção foi o caminho para chegarmos aos cruzamentos lingüísticos, que comprovariam não só a existência de alguns moldes já anteriormente armazenados como também revelariam uma falha de condicionamento indispensável e adequado à assimilação da nova forma de linguagem.

Sabemos que um modelo, um padrão, deverá representar um grupo significativo de falantes para que a investigação adquira um cunho real e procedente, portanto, deixamos de lado as manifestações consideradas puramente subjetivas. 
Observamos que algumas normas individuais se realizam na infinita variedade e multiplicidade da atividade lingüística concreta e se constituem em um sistema de realizações normais - uma abstração conseguida através de estudos comparativos e reflexões que serão úteis à composição de um quadro informativo das dificuldades do aprendiz - quais os elementos funcionalmente pertinentes e não-pertinentes para esse fim

Segundo Coseriu (1969, p. 52), 'o sistema pode se considerar como um conjunto de "imposições", mas também, e talvez melhor, como conjunto de "liberdades", que admite infinitas realizações e só exige que não se afetem as condições funcionais do instrumento lingüístico'. Assim, mais do que impor normas rígidas ao indivíduo, o sistema apresenta-se disponível, ao the proporcionar os meios para sua expressão inédita, mas, ao mesmo tempo compreensível, para os que utilizam o mesmo sistema. Considera-se a compreensão da fala - a comunicação - um fator preponderante na avaliação das estruturas, formas e opções usadas na manifestação oral.

O sistema, ainda constituindo a forma ideal alcançada pela atividade lingüística de um grupo ou comunidade, aparece de certa forma desligado, afastado do falar concreto, que surge como uma forma menos disciplinada, imprópria mas real e atinge, assim, seu principal objetivo: a comunicação.

Apesar de o sistema proporcionar os meios para a expressão de uma certa forma original e afastada do falar concreto, procuramos não nos distanciar da pertinência que uma forma inédita possa ter na composição de um futuro projeto, nem daquela de interferir na possibilidade de encontrarmos na forma inovadora um meio plausível de comunicação.

Cabe enfatizar que os atos lingüísticos correspondem, muitas vezes, a intuições inéditas, condicionamento e transferências da língua materna, ou anterior, gerando atos de recriação que se estruturam em modelos precedentes, mas que acabam sendo aceitos pela sua capacidade comunicativa. Por esse motivo, buscamos levantar toda a originalidade expressiva dos indivíduos falantes entrevistados - muitas vezes, um cruzamento entre a nova língua e a anterior para uma investigação e análise mais profunda da interlíngua.

Podemos retirar dela dois modelos: o inglês e o português representados adiante no quadro da interlíngua. 
Interlíngua

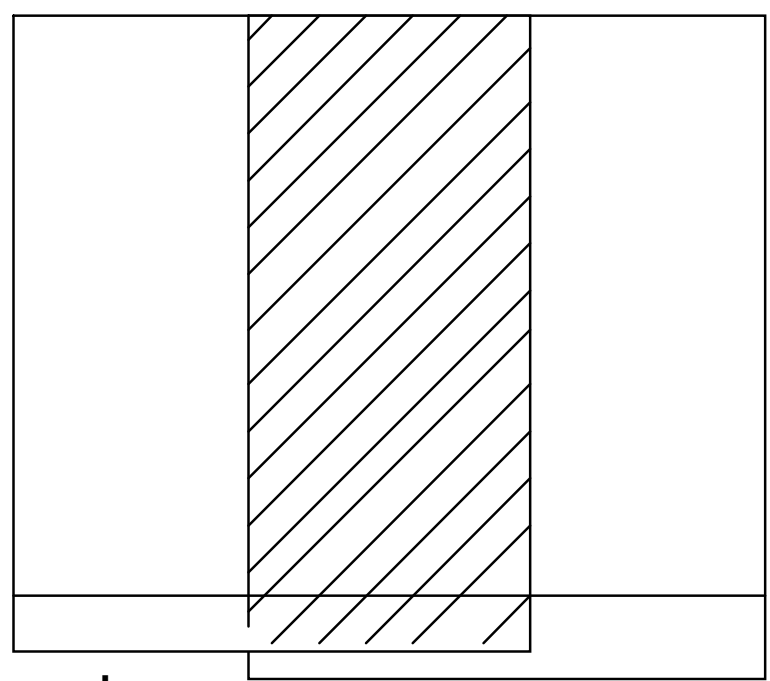

$\mathbf{L}_{1}$

Quadro 1 - $\mathrm{L}_{1}$ e $\mathrm{L}_{2}$ Interlíngua

$\mathbf{L}_{2}$

Todas essas reflexões nos remetem diretamente à teoria de Krashen (1981) sobre a aquisição-aprendizagem de $L_{2}$.

Para Krashen (1981), o estudante adulto de uma segunda língua $\left(L_{2}\right)$ a desenvolve com base em dois sistemas de processos psicológicos, possivelmente independentes, para processar e produzir enunciados nessa língua: um sistema adquirido (processos de aquisição) e outro sistema aprendido (processos de aprendizagem). Esse mesmo autor, em 1982, acrescenta que a aquisição de uma segunda língua $\left(L_{2}\right)$, por ser um processo similar à aquisição de $L_{1}$, resulta numa competência que se caracteriza como um conhecimento sub-consciente das regras dessa língua. As orações soam corretas e apropriadas, as pessoas podem se corrigir embora não saibam, conscientemente, que regra lingüística desrespeitada motivou a correção. Ainda segundo esse autor, outra maneira para desenvolver a competência de uma $L_{2}$ é empregar o processo por ele denominado aprendizagem. Esse processo se apoia no conhecimento explícito de $\mathrm{L}_{2}$ ou em saber conscientemente suas regras e ser capaz de expressá-las.

No que respeita à interlíngua, através das entrevistas, consideradas um falar concreto - única realidade investigável da linguagem - elaboramos alguns grupos de dificuldades, sempre procurando conservar os aspectos comuns que podem ser 
comprovados nos atos lingüísticos que estão sendo considerados: Nesse caso eliminamos tudo o que apresentasse aspectos totalmente originais, variantes individuais, circunstanciais ou momentâneos - ocorrências inéditas - para serem comentados em itens ou capítulos separados. No entanto, algumas realizações consideradas atos de criação inédita foram valorizadas por cumprirem com uma condição essencial da linguagem, que é a comunicação.

\subsection{METODOLOGIA E TÉCNICAS DE ANÁLISE}

Gravadas 40 entrevistas com estrangeiros, falantes da língua Inglesa $\left(L_{1}\right)$ e usuários da língua Portuguesa $\left(\mathrm{L}_{2}\right)$, passamos ao trabalho de transcrição das respectivas falas, para estabelecermos um corpus e procedermos ao levantamento e à tipificação das dificuldades detectadas. Após a análise do material obtido, realizamos nosso trabalho com base em apenas seis entrevistas (cf. doc. ANEXO C). Tal atitude se deveu ao fato de que os textos em questão não só aumentavam o número de ocorrências das dificuldades reveladas pelos demais textos, como também as ampliavam, proporcionando-nos maior diversidade de problemas. Com base nesse material e com nosso estudo direcionado aos problemas relativos às escolhas lexicais, partimos para a análise contrastiva estabelecendo um paralelo entre a fala do entrevistado (Interlíngua) e a $L_{2}$ (Língua Portuguesa). Desta forma, pudemos evidenciar o comportamento adotado pelos falantes de $L_{2}$ para suprirem suas dificuldades em situações de comunicação interpessoal.

Para a realização das entrevistas foram selecionados dois grupos de falantes de $L_{2}$ : um constituído por falantes do inglês britânico e outro por falantes do inglês americano, todos com experiência de aprendizado em escolas de português para estrangeiros.

A fim de que o texto das entrevistas resultasse numa fala mais próxima das manifestações orais espontâneas, organizamos um questionário, a título de roteiro, para direcionar nossa conversa com os entrevistados (cf. doc. Anexo B ).

Nossa preocupação em aplicá-lo era estimular os entrevistados para que se sentissem à vontade, emitissem suas opiniões sobre suas expectativas em relação à aprendizagem de $L_{2}$ para que revelassem as possíveis causas de suas dificuldades 
de expressão e ainda apresentassem sugestões úteis às novas orientações metodológicas, tendo em vista um ensino futuro - aprendizagem de $L_{2}$.

O material assim coletado, transcrito em sua íntegra e organizado primeiramente de maneira formal e ordenada, constituiu o corpus inicial de nossa pesquisa (cf. doc. Anexo C).

Durante a primeira sondagem desse corpus foram levantadas as hipóteses:

$\mathrm{Na}$ aprendizagem da língua portuguesa, seria grande parte dos erros cometidos pelos falantes da língua inglesa provocada por problemas diversos de interferência, os quais se manifestam em todos os níveis lingüísticos: morfológico, sintático-semântico e lexical?

A partir de uma fixação adequada das estruturas aprendidas, haverá uma grande probabilidade de decréscimo de interferência?

Esses fatores foram considerados para avaliação e caracterização do erro. Entretanto, com base na diversidade das ocorrências-problema concentramo-nos inicialmente neste trabalho ao estudo das classes de palavras em seus respectivos contextos. Daí o estabelecimento de um subcorpus - o corpus definitivo para o estudo, cujos resultados apresentamos neste trabalho.

Para a realização das entrevistas optamos pela fala de dois grupos de estrangeiros, falantes do inglês, com experiência na aprendizagem do português, conforme mencionado.

Tendo em vista a delimitação do universo da pesquisa, alguns critérios foram considerados na seleção dos entrevistados:

- ser falante nativo do inglês (britânico ou americano);

- ter acompanhado algum curso de português para estrangeiros (dentro ou fora do Brasil);

- ter adquirido experiência anterior em português.

A busca de nomes das pessoas selecionadas para esse fim e de seus respectivos endereços aconteceu através de nossa própria iniciativa e de algumas indicações de coordenadores de cursos de português para estrangeiros, que acabaram demonstrando bastante interesse pelo resultado da pesquisa.

Definidos os critérios mencionados, seguem as etapas realizadas para a delimitação do corpus definitivo e elaboração deste texto:

1-. contato com as entidades: Conselho Britânico e Cursos de Português para Estrangeiros (USP). Neste momento, procuramos nos dirigir aos locais em que se 
encontravam pessoas que permitissem um contato, com a preocupação de respeitar rigorosamente a disponibilidade de cada uma;

$2^{\text {a }}$ - contato com os estrangeiros, por carta, para consultá-los sobre seu interesse em participar da pesquisa, sobre sua disponibilidade de tempo e determinação de horário para a realização da entrevista. Para esse fim, elaborou-se uma carta-padrão, carta-convite, que foi enviada a cada possível participante (cf. doc. Anexo A);

3-a realização das entrevistas, previamente programadas, que aconteceram pessoalmente no local, dia e hora sugeridos pelos estrangeiros interessados e gravação da fala em fitas cassetes. Todo o trabalho foi enfocado na transcrição da fala desses participantes, que atenderam a um questionário com 31 (trinta e uma) perguntas a serem respondidas pelo critério de livre escolha do entrevistado (cf. doc. Anexo B);

4⿳亠丷⿵冂- - transcrição da fala em sua íntegra para estabelecimento de um corpus.

5'- comparação das falas resultando a opção pelo aproveitamento de apenas seis das entrevistas (cf. doc. Anexo C);

6ª- delimitação e estabelecimento de um subcorpus, constituído de contextos com as dificuldades relativas às classes de palavras.

7ạ- levantamento geral das dificuldades relativas às classes de palavras: substantivo, adjetivo, verbo, advérbio e construções - preposição e conjunção. (Anexo D)

Em seguida, reunimos essas dificuldades em seus respectivos contextos para que pudessem elucidar as intenções e recursos adotados pelos entrevistados na tentativa de representar melhor suas idéias através de suas disponibilidades lingüísticas. Os entrevistados deixavam transparecer sempre um certo empenho em obedecer e aplicar as orientações recebidas nos cursos, mas, muitas vezes, não conseguiam fazê-lo e acabavam revelando inseguranças, assimilação inadequada, impropriedades lexicais que nos estimularam a uma investigação mais apurada das causas efetivas dos tropeços relativos ao uso das classes de palavras. Preocupados com a dimensão do trabalho, resolvemos fazer um recorte e, então, nos concentrarmos na escolha lexical dos nomes (formação e uso do substantivo), formas nominais e nominalizadas - objetivo específico do nosso trabalho, ampliando assim o assunto desenvolvido na Dissertação de Mestrado. 
Definido o corpus, demos início ao trabalho de análise minuciosa do material, de acordo com os seguintes passos:

a) - levantamento das inadequações relativas ao uso das diferentes classes de palavras para a criação do subcorpus;

b) - elaboração de um quadro contrastivo - um quadro de correspondências (Anexo D) entre Interlíngua (I) e $L_{2}$ que corresponde a um levantamento de impropriedades no uso das diferentes classes de palavras em seus respectivos contextos (Interlíngua) com correspondência paralela e mais próxima possível em $\mathrm{L}_{2}$, tendo em vista sempre representar a mais legítima intenção e pensamento dos entrevistados;

c) - apresentação dos erros revelados pela análise contrastiva, concentrada, numa fase inicial, no uso inadequado das classes de palavras, incluindo construções (preposição e conjunção);

d) - estudo das causas de tais dificuldades e referências relativas ao tipo de erro.

e) - levantamento dos recursos adotados pelos entrevistados para suprirem suas dificuldades;

f) - organização dos recursos em diferentes grupos de acordo com a natureza da dificuldade - estabelecimento de uma tipologia de erros (análise e considerações sobre palavras e expressões aceitáveis e inaceitáveis, isto é, que se excluem), de acordo com todas as disponibilidades lexicais, semânticas e morfossintáticas existentes no sistema geral e nas possíveis normas.

g) - enfoque em uma fase intermediária, com base nas falhas relativas aos verbos e nomes através dos respectivos sintagmas verbais e nominais.

h) - busca, em conseqüência dos estudos acima e pela pertinência ao nosso trabalho já em uma fase final, por uma concentração nos nomes-substantivos, formas nominais e nominalizadas, em nível paradigmático e sintagmático.

i) - levantamento de algumas sugestões para solucionar ou minimizar essas dificuldades, evitando os numerosos embaraços dos falantes.

A configuração do levantamento dos erros computados segue uma seqüência com recortes - um afunilamento - que pode ser representado da seguinte maneira: 


\begin{tabular}{|l|l|l|l|l|}
\hline \multicolumn{1}{|c|}{ Fase inicial } & \multicolumn{1}{|c|}{$\begin{array}{c}\text { Fase } \\
\text { Intermediária }\end{array}$} & & Fase final \\
\hline $\begin{array}{l}\text { Classes de } \\
\text { palavras }\end{array}$ & $\rightarrow$ & $\begin{array}{l}\text { Verbos (sintagmas verbais) } \\
\text { Nomes (sintagmas } \\
\text { nominais) }\end{array}$ & $\rightarrow$ & $\begin{array}{l}\text { Nomes-substantivos, formas } \\
\text { nominais e nominalizadas }\end{array}$ \\
\hline
\end{tabular}

Quadro 2 - Fases da investigação dos erros

Ao analisarmos o corpus, à primeira vista os erros dos entrevistados nos pareceram bastante naturais em se tratando de fala de estrangeiros; outros, extremamente intrigantes, exigiriam maior atenção e um estudo mais aprofundado.

Por esse motivo, voltamos nossa atenção para os erros que se relacionavam diretamente com os processos de formação e uso dos nomes, com o emprego de certas formas verbais, através de um processo de transferências descuidadas e inadequadas. Estas, por sua vez, despertaram nosso interesse para um encaminhamento mais funcional na organização de uma grade de dificuldades e forneceram pré-requisitos para uma possível criação de um campo lexical bastante útil ao ensino de língua portuguesa para estrangeiros. Consideramos, então, que o estudo das relações entre as classes de palavras constituía um recurso fundamental para o ensino da $L_{2}$,_pois contribuiria para sua eficácia no trabalho de reflexão e inferência sobre as idéias e informações, necessárias a uma adequada manifestação verbal.

Assim, resolvemos investigar, estudar e tipificar as dificuldades apresentadas pelos falantes de português $L_{2}$, em situações discursivas que revelassem ou denunciassem embaraços, inseguranças, falta de conhecimento relativos às nominalizações paradigmáticas e sintagmáticas. As primeiras relativas à formação e uso dos nomes em suas diferentes classes e as segundas, à combinação de palavras, na tentativa de representação dos pensamentos.

O material colecionado foi organizado com base na fundamentação teórica apresentada.

Assim posicionados, passaremos aos estudos a priori. 


\section{CAPÍTULO 2 - ANÁLISE CONTRASTIVA A PRIORI}

Neste capítulo, a análise contrastiva a priori será utilizada apenas como base de investigação e análise sobre as disponibilidades lexicais relacionadas às formas de nominalização em nível paradigmático e sintagmático, no português e no inglês, conforme previsto na introdução desta tese.

Ao buscarmos uma análise contrastiva que apresentasse uma pertinência mais próxima dos nossos objetivos, concentramo-nos em assuntos relativos às nominalizações, incluindo as formadas por derivação sufixal e as contextuais com presença de determinantes e modificadores. Tal roupagem concorreu para elucidar e destacar núcleos nominais e sua função específica na composição e na organização de sintagmas nominais - os chamados nominal clusters em inglês, correspondentes aos nomes acompanhados de seus modificadores em português.

Fomos, ainda, buscar informações relativas às formas nominais de infinitivo, gerúndio e particípio com vistas à confirmação de nossas hipóteses e reflexões.

Para o tratamento dessas formas consultamos as gramáticas de Cunha (1972) e Bechara (1980).

Procedemos dessa forma para justificar alguns mecanismos na produção de erros a serem apresentados na segunda parte desta tese, destinada à análise a posteriori.

\subsection{NOMINALIZAÇÕES}

O problema das nominalizações tem atingido um nível bastante polêmico pelo fato de elas se basearem em inúmeras teorias que, muitas vezes, acabam criando vertentes com caráter mais especulativo do que convincente e funcional. Como já mencionado, segundo Krashen (1981), a aquisição de uma segunda língua $\left(L_{2}\right)$, por ser um processo similar à aquisição de $L_{1}$, resulta numa competência que se caracteriza como um conhecimento subconsciente das regras dessa língua, reconhecendo-se o erro, sem que se tenha consciência de regra lingüística desrespeitada que o justifique. 
Apesar disso, é importante para esse autor conhecermos algumas abordagens teóricas que possam direcionar-nos na criação de uma metodologia mais segura, relacionada com a aprendizagem de uma segunda língua $\left(L_{2}\right)$. Para elucidar sua opinião, o lingüista menciona o livro The Grammar of English Nominalizations, Lees (1960), em que o autor sustenta que quase todas (senão todas) as nominalizações como as frases nominais que apresentam entre seus elementos uma relação sintática, deveriam ser derivadas de sentenças por meio do uso de transformações sintáticas. Portanto, uma frase nominal como the milking machine é derivada de uma forma subjacente The machine is for milking, sugestão que acabou sendo bastante divulgada e avaliada por vários autores.

Algum tempo depois, Chomsky (1965) contrariava a opinião de Lees (1960), sugerindo que certas nominalizações deveriam ser lexicais e não transformacionalmente derivadas.

Essa nova posição, à qual poderíamos nos referir como lexicalista em oposição à opinião de Lees, que propõe uma posição transformacionalista, sustenta que as relações sintáticas existentes nessas nominalizações lexicalmente derivadas são respaldadas por algumas regras lexicais, provavelmente não tão diferentes do que ocorre em transformações em potencial. Nos anos seguintes, nenhuma dessas opiniões se apresentou como argumentação suficiente que pudesse permitir avaliação cuidadosa da estrutura e nem como convicção quanto às alegações de defesa a cada uma delas; foram, então, reconhecidas ainda como insatisfatórias.

Para Fraser (1972) algumas nominalizações como, as criadas pelo sufixo -ing, deveriam ser avaliadas de maneira diferente das obtidas através de sufixos como ation e -ment. Para esse estudioso, uma análise minuciosa permitirá evidenciar que numa -ing action nominalization existe uma ação por trás da estrutura - uma nominalização de ação, apoiada mais diretamente na visão transformacionalista e não lexicalista, como sugerem outros lingüistas.

Toda essa controvérsia, no entanto, apesar de esclarecedora para o encaminhamento de nossas reflexões, não é prioritária para nossas preocupações básicas, que se concentram nas divergências morfossintático-semânticas existentes nas estruturas superficiais entre as duas línguas, divergências essas bastante evidenciadas na análise contrastiva. Interessa-nos, portanto, a nominalização realizada em atos de fala. 
Antes, porém, de colocar na prática as informações recolhidas durante nossa investigação acerca de componentes nominais e suas relações dentro de contextos lingüísticos, dedicamos nossa atenção aos paralelos contrastivos

\subsection{ESTUDOS CONTRASTIVOS}

Para o estabelecimento das correspondências entre as línguas inglesa e portuguesa consideramos:

- substantivos em -ing;

- infinitivo;

- modificadores do nome.

\subsubsection{Substantivos em -ing}

A partir de entrevistas realizadas com estrangeiros, falantes da língua portuguesa $\left(L_{2}\right)$, procuramos detectar as dificuldades referentes à assimilação da nova língua. Algumas reações e manifestações dos entrevistados despertaram nosso interesse por uma averiguação mais próxima e minuciosa de certos erros considerados graves e prejudiciais a uma comunicação mais aceitável e natural em $\mathrm{L}_{2}$.

Daí termos direcionado inicialmente nossa pesquisa ao estudo da formação dos substantivos provenientes de uma forma verbal em -ing, no inglês, os quais, muitas vezes, constituem problema até mesmo para os falantes nativos. A origem e fenômenos que envolvem esse tipo de substantivo têm atigindo até mesmo em inglês um nível bastante polêmico pela existência de inúmeras teorias controversas que, muitas vezes, acabam apresentando conclusões sem um reconhecido fundamento lingüístico.

Segundo Fraser (1972), as nominalizações criadas pelo sufixo -ing apresentam uma formação diferente das obtidas através dos sufixos do tipo -action e -ment, em nível superficial, conforme mencionado. A nominalização de ação, 
segundo esse autor, pode ser observada pelas necessárias relações e interpretações morfossintático-semânticas existentes, nessa estrutura, entre as palavras primitivas e derivadas, como se verifica entre teach e teaching, em nível profundo. Esse fato gera dificuldades - um erro - no processo de formação de palavras em $L_{2}$, devido a transferências inadequadas de formas que não correspondem àquelas existentes em português. Esse erro é, às vezes, reconhecido pelo falante de $L_{2}$, que não o associa conscientemente a nenhuma regra lingüística desrespeitada.

Como nossa preocupação se concentra nas divergências morfossemânticas de estruturas superficiais entre as duas línguas, o estudo das funções das formas em -ing apresentado por Thompson e Martinet (1980), para a língua inglesa, constituir-se-á para nós um precioso subsídio na avaliação das causas das dificuldades (interferências), encontradas nas manifestações em $L_{2}$.

Nessa avaliação, tomaremos por base as diferentes funções estabelecidas por esses autores e suas correspondentes em língua portuguesa.

A partir das disponibilidades de formas existentes em cada uma das respectivas línguas em questão e do estabelecimento do paralelo entre elas, levantaremos as diferenças encontradas em ambas.

Para alguns autores, como Aronson (1978), é o contraste entre interlíngua e $L_{2}$ que vai sugerir o melhor caminho para a investigação das interferências entre as duas línguas ${ }^{3}$.

Assim, motivados para estabelecer as inferências resolvemos considerar, inicialmente, o comportamento das formas de gerúndio e particípio presente, de acordo com a classificação proposta, para o inglês, por Thomson e Martinet (1980) e em seguida investigar a correspondência dessas formas em português.

A comparação dos registros das respectivas formas lingüísticas será apresentada na seqüência desta exposição.

\footnotetext{
3 Por interferência entendemos aquilo que apresenta uma não-correspondência direta entre duas línguas quanto à escolha lexical (semântica), à forma (morfologia) e à combinação das palavras (sintaxe).
} 


\subsubsection{Gerund e participle}

$\mathrm{Na}$ apresentação do gerund e do participle serão consideradas a nomenclatura, a forma e a função dessas formas nominais do verbo. Verifiquemos as devidas correspondências do gerund e do participle em inglês e português.

Quanto à nomenclatura, tomando-se por base a classificação apresentada por Celso Cunha (1975), entre outros, no que respeita às formas nominais de gerúndio e de particípio em língua portuguesa e comparando-a com a existente na língua inglesa, verifica-se que, em se tratando de nomenclatura, não há correspondência entre os termos gerund/infinitivo, present participle/gerúndio e past participle/particípio, usados nas duas línguas. Apesar da semelhança morfofonológica, esses termos não encontram equivalência funcional.

Atente-se para as correspondências:

INGLÊS

\section{PORTUGUÊS}

Gerund (gerúndio)

$\phi$

Present Participle

Gerúndio

Past participle

Particípio

Conforme se pode verificar, o termo gerund do inglês não encontra correspondência em português. Quanto aos termos Present Participle e Past participle, o primeiro corresponde, em português, ao gerúndio e o segundo, ao particípio. Por esse motivo, o emprego deles, através de uma simples tradução literal, torna-se inviável.

Quanto à forma comparemos:

INGLÊS

Gerund

Present Participle

Past participle

$$
\begin{aligned}
& \text { verb- + -ing } \\
& \text { verb- + -ing } \\
& 3^{\text {rd }} \text { form usually -ED }
\end{aligned}
$$

\section{PORTUGUÊS}

Infinitivo (-ar, -er, -ir)

$-N D O$

$-D O$

Conforme se verifica no quadro acima, a forma do gerund em -ing corresponde àquelas em -ar, -er e -ir do infinitivo da língua portuguesa. No que se refere à forma do present participle e à do past participle, em língua portuguesa, a 
primeira corresponde àquela em -ndo e a segunda, àquela em -do. Não há, portanto, equivalência quanto ao aspecto abordado.

Quanto à função, a partir da classificação de Thomson e Martinet (1980) para as formas em -ing da língua inglesa, as funções do gerund e do participle: present participle e past participle, serão confrontadas com suas respectivas correspondentes na língua portuguesa.

\subsection{Gerund}

Apreciemos, a ocorrência do gerund na seguinte seqüência: como sujeito de uma oração; precedido de preposição; complementando verbos do tipo to enjoy e to detest, entre outros, (estes exigem, em inglês, um complemento representado por uma ação contínua) e constituintes de nomes compostos.

Lembramos que, nesta etapa destinada ao embasamento teórico de nosso trabalho de análise a priori para a análise a posteriori, consideramos a AC a partir da língua inglesa contrastando-a com a língua portuguesa. Como gerund sujeito de oração estabelecemos as seguintes correspondências:

INGLÊS

Swimming is a healthy sport.

Parking was difficult yesterday.

Reading French is easy.

The saying: 'Seeing is believing'.

\section{PORTUGUÊS}

Nadar (a natação) é um esporte saudável.

Estacionar (o estacionamento) foi difícil ontem.

Ler francês (a leitura do francês) é fácil. No dizer (No dito): 'Ver é acreditar'.

Conforme se verifica, o gerund do inglês corresponde, em português, a um infinitivo ou a uma nominalização do verbo (derivação sufixal). Trata-se de uma interferência bastante visível.

Do gerund preposicionado (sintagmas preposicionados) prep. + gerúndio, tomamos como amostra: 
INGLÊS

She is fond of climbing.

They are interested in learning

Chinese.

After swimming, I felt cold.

He was accused of smuggling.

\section{PORTUGUÊS}

Ela é apaixonada por (gosta de, tem loucura por) escalar montanha (pela escalada de Eles estão interessados em aprender (na aprendizagem) do chinês.

Depois de nadar (da natação), senti frio.

Ele foi acusado de contrabandear (de contrabando).

Observa-se que, nos exemplos elencados, o gerund corresponde, em português, a um infinitivo ou, apenas eventualmente, a uma nominalização do verbo (derivação sufixal ou regressiva). A interferência, nesses casos é facilmente percebida.

Comprovam o uso do gerund, funcionando como complemento que representa uma ação contínua, em inglês, depois verbos do tipo to enjoy e to detest, entre outros, os exemplos:

INGLÊS

She enjoys teaching.

He detests writing letters.

He proposed traveling by helicopter.

Forgive my interrupting you'.

\section{PORTUGUÊS}

Ela gosta de ensinar (do ensino).

Ela detesta escrever (a escrita de) cartas.

Ele propôs viajar (viagem) de helicóptero.

Perdoe-me por interrompê-lo/a (por minha interrupção).

O paralelo estabelecido evidencia que ocorrem as mesmas interferências verificadas no item anterior.

Em nomes compostos (lexias compostas), o gerund + noum pode ser apreciado em:

INGLÊS

A diving board.

A sleeping bag.

The sitting room.

Driving license.

\section{PORTUGUÊS}

Prancha de mergulhar (de mergulho).

Um saco de dormir.

A sala de estar.

Licença para guiar (Carteira de motorista). 
Embora as interferências sejam semelhantes às registradas no item anterior, nota-se uma incidência maior relativa ao infinitivo do português.

\subsection{Participle: present e past construtions}

Verifiquem-se, na seqüência, as respectivas correspondências, entre as línguas em questão, no uso do present participle e do past participle ainda a partir da classificação de Thomson e Martinet (1980)

\subsection{Present participle}

Esta forma participial (present participle) se apresenta como adjetivo, e é também usada para formar os tempos contínuos e ainda ocorre depois de verbos de sensação, conforme as respectivas correspondências a seguir.

Do uso do present participle como adjetivo elencamos:

INGLÊS

Running water.

Following examples.

Smiling girl.

Bleeding fingers
PORTUGUÊS

Água corrente.

Exemplos seguintes.

Menina sorridente.

Dedos sangrando (em sangramento)

Nota-se pelos exemplos uma interferência referente ao uso do antigo particípio presente em português, que corresponde, hoje, à função de adjetivo e substantivo. Trata-se de um uso analisável como transferência se considerarmos, nesse caso, uma oração relativa subjacente, a ser reconhecida por um desmembramento da forma sintética: sorridente pela analítica que sorri; corrente, por que corre: água corrente: água que corre e menina sorridente: menina que sorri. Na formação de tempos contínuos, o present participle ocorre em: 
INGLÊS

$\mathrm{He}$ is working.

He is learning.

She was dreaming.

She was singing.
PORTUGUÊS

Ele está trabalhando.

Ele está aprendendo.

Ela estava sonhando.

Ela estava cantando.

Nota-se, nesses casos, uma correspondência direta do present participle do inglês com o gerúndio do português.

Depois de verbos de sensação temos:

INGLÊS

I saw flames rising and heard

people shouting.

I heard him booking seats.

I smell something burning.

I felt the house shaking.
PORTUGUÊS

Eu vi chamas subirem (subindo) e ouvi pessoas gritarem (gritando).

Eu o ouvi reservar (reservando) lugares.

Eu sinto alguma coisa queimar (queimando).

Eu senti a casa tremer (tremendo).

Nesses exemplos ocorre, em inglês, uma dupla possibilidade que corresponde a uma transferência direta do português. A única restrição recai nas formas do infinito flexionado em português, com uma invariabilidade bastante marcada, existente na forma básica do infinitivo inglês.

\subsection{Past participle}

Quanto ao past participle, os exemplos se restringem ao seu uso como adjetivo.

Observemos as correspondências:

INGLÊS

Stolen money.

A written report.

Fallen leaves.

Broken glass.
PORTUGUÊS

Dinheiro roubado

Um relatório escrito.

Folhas caídas

Copo quebrado. 
Temos agora uma correspondência direta entre o past participle do inglês e o particípio do português. A única interferência acontece em nível sintático: em inglês o past participle (adjetivo) vem anteposto ao substantivo, enquanto em português vem posposto a este.

Cabe lembrar que adjetivos formados pelo particípio presente, como amusing, tiring, infuriating, boring, são ativos e significam "causar um efeito". Adjetivos formados pelo particípio passado como, amused, tired, infuriated, bored, são passivos e significam "atingidos de uma determinada maneira".

Consideremos as respectivas correspondências:

INGLÊS

He told us amusing stories.

We were amused by his stories.

The play was boring.

The audience was bored.

The work was tiring.

The workers soon became tired.

An infuriating woman,

(She made us furious).

An infuriated woman.

(Something or somebody made her furious).

\section{PORTUGUÊS}

Ela nos contava histórias divertidas.

Nós ficávamos entretidos com suas histórias

A peça de teatro estava enfadonha.

A platéia estava enfadada.

O trabalho estava cansativo.

Os trabalhadores logo ficaram cansados.

Uma senhora furiosa.

(Ela nos tornou furiosos).

Uma senhora enfurecida.

(Alguma coisa ou alguém fê-la furiosa).

As mesmas relações de causa (voz ativa) e efeito (voz passiva) existentes na forma do inglês ocorrem nas formas do português, conforme se constatou pelos exemplos apresentados.

Há de ressaltar, no entanto, que uma dessas formas elencadas merece atenção especial por se tratar de uma interferência de present participle em inglês amusing. Essa forma, apesar de acrescida do sufixo -ing, vai corresponder a uma forma de particípio em português, que foge à norma padrão, qual seja, divertida. 
Conforme se verifica os substantivos em -ing desempenham diferentes funções na língua inglesa não havendo para eles uma só forma, mas várias correspondentes na língua portuguesa.

A partir do paralelo usado para demonstrar a relação entre as duas línguas evidencia-se que as formas assumidas em português pelos correspondentes substantivos em -ing do inglês permitem-nos aquilatar as possíveis causas das dificuldades no processo de substantivação de um verbo (nominalização), principalmente em casos que exigem o acréscimo de sufixos (derivação sufixal), ou no processo da formação de deverbais (derivação regressiva).

Veja-se o elenco:

\begin{tabular}{|l|l|l|}
\hline INGLÊS & PORTUGUÊS & NOMINALIZAÇÕES \\
\hline Swimming & Natação & $\begin{array}{l}\text { Nominalização do verbo (derivação } \\
\text { sufixal) }\end{array}$ \\
\hline Parking & Estacionamento & $"$ \\
\hline Learning & Aprendizagem & $"$ \\
\hline Reading & Leitura & $"$ \\
\hline Climbing & Escalada & Nominalização do particípio \\
\hline Seeing & Ver (o ver) & Nominalização do infinitivo \\
\hline Shaking & Abalo & Deverbal \\
\hline Diving & Mergulho & $"$ \\
\hline Teaching & Ensino & $"$ \\
\hline Writing & Escrita & Nominalização do particípio \\
\hline Amusing & Divertida & Adjetivos oriundos de particípio \\
\hline Infuriating & Enfurecida & $"$ \\
\hline Running & Corrente & $\begin{array}{l}\text { Adjetivos (antigo particípio } \\
\text { presente) }\end{array}$ \\
\hline & & \\
\hline
\end{tabular}

Quadro 3 - Processos de nominalização

Pela amostragem exibida verificam-se, em $\mathrm{L}_{2}$, dificuldades na substantivação e adjetivação do verbo a partir das formas em -ing, devido à produtividade desse sufixo, em contraposição à variedade de correspondências em português. 


\subsubsection{Paralelo contrastivo do -ing: inferências e hipóteses}

Partimos do princípio que o uso das formas lexicais do português $\left(L_{2}\right)$, correspondentes àquelas terminadas em -ing na língua inglesa $\left(L_{1}\right)$, constitua um obstáculo ao ensino-aprendizagem do português língua estrangeira. Tal problema se deve ao fato de que na língua inglesa uma única forma lexical em -ing desempenha diferentes funções, pois as palavras assim construídas podem passar livremente de uma para outra classe gramatical por um processo chamado "conversão". (cf. Ullmann,1964, p. 111).

Verifica-se, entretanto, que as formas terminadas em -ing $\left(L_{1}\right)$ estabelecem correspondência direta com as formas do gerúndio terminadas em -ndo $\left(\mathrm{L}_{2}\right)$, as quais, diferentemente do que ocorre em inglês, não podem preencher todas as funções desempenhadas pelas primeiras.

Toda essa disponibilidade encontrada na língua inglesa fica ainda mais ampliada quando encontramos esse recurso -ing adotado como alternativa para caracterizarmos abstrações, idéias generalizadas, não só nomeando como atribuindo qualidades extensivas às já estabelecidas na língua. O sufixo -ing adquire uma potencialidade que acaba facilitando a expressão através de seus usos alternativos para os falantes, um recurso para suprir suas dificuldades.

A partir dessas concepções, elaboramos um quadro - panorama geral e específico - de que constam diferentes registros de -ing encontrados no sistema da língua inglesa, incluindo algumas normas técnico-científicas. Em outras palavras, um estudo completo do sufixo -ing: uma abordagem quanto à forma, posição, combinação e função, conforme quadros anexos 4, 5, 6 e 7.

\subsubsection{Infinitivo}

Neste item, o infinitivo será observado em seu uso, enquanto substantivo (nome) e enquanto verbo.

Lembramos inicialmente que os usos do infinitivo constituem um dos problemas mais sérios encontrados em Português. Ao contrastarmos português e 
inglês em um nível superficial, estaremos estabelecendo formas de comportamento da referida forma nominal, para distinguir as semelhanças e diferenças entre as línguas.

Verificaremos até que ponto duas construções gramaticais diferentes do português e Inglês compartilham de idênticas estruturas profundas, mas diferem nas maneiras em que as estruturas profundas subjacentes são transformadas até atingir às suas formas superficiais.

Em português o infinitivo assume duas formas, a saber:

- infinitivo impessoal: falar

- infinitivo pessoal: falar eu, falares tu (falar você), falar ele, falarmos nós, falardes vós (falarem vocês), falarem eles.

Uma vez que as segundas pessoas do singular e plural do infinitivo não são normalmente encontradas no português falado, e que a primeira e terceira pessoas desse tempo verbal são iguais falar, podemos dizer que temos somente uma forma de infinitivo no singular, quer ele seja pessoal ou impessoal. Entretanto, a forma pessoal do infinitivo apresenta as terminações -mos e -em correspondentes respectivamente às primeira e segunda pessoas do plural. .

Essas formas do infinitivo podem ser usadas não só com valor verbal como também com valor nominal. Hás casos, no entanto, em que as formas o infinitivo, quer pessoal ou impessoal, são encontradas como nomes sem a perda total de sua força verbal e não levam a marca de plural dos nomes.

Quanto à sua função, o infinitivo em português pode ser usado como sujeito ou objeto de um verbo enquanto nome e, em cláusulas subordinadas, enquanto verbo, conforme se demonstra em:

PORTUGUESE

Ouvir é obedecer.

Proíbo-lhe ir.

Ele chegou antes de sairmos ${ }^{5}$.

Ele chegou antes da gente sair.
ENGLISH

To + inf ${ }^{4}+$ verb + to + inf

To hear is to obey.

Subj. + verb + obj. + to + inf

I forbid him to go.

Subj. + verb + subord. Clause

He arrived before we go out.

\footnotetext{
${ }^{4}$ Em Inglês nos também temos duas espécies de infinitivo, com e sem to: hear - to hear; travel - to travel; know - to know. A escolha do infinitivo com e sem to vai depende do contexto no qual ele aparece.
} 
2.2.2.1 Infinitivo nome (substantivo)

Substantivado, o infinitivo pode vir acompanhado por determinantes e/ou por modificadores, a saber: por artigo, por adjetivo, por locução adjetiva (sintagma preposicionado ou adjetival) ou por advérbio, devido à sua força verbal.

Enquanto substantivo, o infinitivo se faz preceder tanto pelo artigo definido (det art def $+\mathrm{N}$ inf) quanto pelo indefinido (det art ind $+\mathrm{N}$ inf), casos 1 e 2 :

Caso 1:

PORTUGUESE

$\mathbf{O}^{6}$ mugir das vacas.

O mugido das vacas (Part.

Passado)

Caso 2:

PORTUGUESE

Isso aconteceu num abrir e

fechar de olhos.

\section{ENGLISH}

Article + -ing form (noun)

The mooing of the cows.

\section{ENGLISH}

[...] article + -ing form (noun) + prep phrase

That happened in the ${ }^{7}$ twinkling of an eye.

Em ambos os casos, usa-se o artigo como marcador de classe gramatical.

Uma vez substantivado pelo artigo, o infinitivo pode se fazer acompanhar de modificadores adjetivos ( $\mathbf{N}$ inf + mod adj ) ou locuções adjetivas $(\mathbf{N}$ inf $+\mathbf{m o d}$ prep), conforme respectivos casos 1 e 2 a seguir:

Caso1

PORTUGUESE

Ouvíamos o estourar

barulhento dos foguetes.

\section{ENGLISH}

[...] the + adj + ing form (noun) [...]

We heard the noisy bursting of the firecrackers,

\footnotetext{
${ }^{5} \mathrm{O}$ infinitivo pode gerar uma forma de construção com possessivc + substantivo: nossa saída. A terminação mos (1 ${ }^{\text {a }}$ pessoa do plural) do infinitivo se faz representar pelo possessivo: Ele chegou antes de nossa saída, He arrived before + (Pron / verb / prep + poss + -ing form).

${ }^{6} \mathrm{O}$ infinitivo é amplamente reconhecido como um substantivo em tais casos, mas ainda com uma sugestão de ação derivada do verbo.

${ }^{7}$ Embora o verbo nominalizado (forma em -ing) esteja precedido pelo artigo definido the, a idéia indefinida achase expressa no seu modificador: of an eye.
} 
Caso 2

PORTUGUESE

O por do sol é quase sempre bonito no Rio.

Gosto de ouvir o bater das

ondas na praia.
ENGLISH

Article + ing form (noun) + prep. phrase [...]

The setting of the sun is almost always pretty in Rio.

I like to hear the beating of the waves on the beach.

Quando acompanhado de um modificador, o infinitivo normalmente se faz preceder por um artigo ou outro determinante, seguindo a norma da língua portuguesa.

Caso 3

Quando modificado por um advérbio, da mesma forma que na fala anterior, o infinitivo vem precedido de artigo substantivando-o:

ENGLISH

PORTUGUESE

-ing form (verb) + adverb

(0) jogar bem exige muito

Playing well demands a lot of training.

treino.

Nesse caso, o infinitivo pode ou não receber o artigo definido, mas no português ele é normalmente omitido quando empregado numa generalização .

\subsubsection{Infinitivo verbo}

Como verbo, o infinitivo aparece modificado por um advérbio. Se nominalizado, mantém as mesmas características e as mesmas funções sintáticas atribuídas a um substantivo comum, como comprovado por: 
PORTUGUESE

(O) jogar bem ${ }^{8}$ exige muito treino.
ENGLISH

-ing form (verb) + adjective

Playing well demands a lot of training.

Ainda como verbo, o infinitivo pode ou não ser flexionado, subdividindo-se em pessoal ou impessoal.

\subsection{Infinitivo impessoal}

O sujeito expresso ou implícito só aparece em casos em que o sujeito de um verbo precedente funcione como o sujeito desse infinitivo:

PORTUGUESE

Quero ver
ENGLISH

Verb / to + - inf

Nesse caso o sujeito do infinitivo é também o sujeito de um verbo precedente que se acha flexionado. Se o verbo dependente tiver um sujeito diferente, nós teremos em português uma outra construção: verbo/que + sujeito + subjuntivo (oração subordinada) correspondente a Quero que você veja, enquanto em Inglês a construção permanece a mesma: I want you to see. Uma forma como: Quero você ver estaria completamente agramatical.

Cabe lembrar que sujeito de um infinitivo impessoal pode estar representado pelo objeto de um outro verbo que o antecede:

\footnotetext{
${ }^{8}$ Observe a ênfase ampliada sobre a ação transmitida pela mudança do modificador de adjetivo para advérbio na seguinte estrutura:

Portuguese:

English

Ouvíamos o bater contínuo do martelo na parede. We heard the continual beating of the hammer on the wall.

O bater Quando impessoal, o infinitivo pode ter ou não um sujeito expresso. continuamente do martelo tornouse irritante. The hammer beating continually became annoying.
} 
PORTUGUESE

Deixe me ver.

Ele nos manda entregar os pacotes em casa.
ENGLISH

Verb / object / inf (without to)

\section{Let me see.}

Subject / verb / object / to + inf

He orders us to deliver the packages to his house.

Observe-se que, nesses casos, o infinitivo segue imediatamente o verbo flexionado tendendo a permanecer impessoal. Mas, se o infinitivo estiver separado de um verbo flexionado (verbo principal), por um complemento verbal, representado por um substantivo, haverá maior probabilidade de que o infinitivo se torne pessoal. Quanto maior a separação, maior a probabilidade de que necessitemos usar a forma pessoal.

Veja -se:

PORTUGUESE

Papai nos deu ordem de irmos passear.

\section{ENGLISH}

[...] verb / pron. (object) / noun / to + inf [...]

Daddy gave us orders to take a walk.

\subsection{Infinitivo pessoal}

Quanto ao infinitivo pessoal, seu sujeito deverá estar expresso ou implícito. Se o sujeito lógico estiver expresso como o objeto do verbo precedente, então o infinitivo parmanecerá, geralmente, impessoal, como em: 
PORTUGUESE

Ele pediu para $\mathrm{eu}^{9}$ fazer a

mudança.
ENGLISH

[...] verb + object + to + inf

He asked me to do the moving.
Antes deles entrarem, a portas

foram fechadas.
Before (conjunction) + subject + verb

Before they came in, the doors were closed.

A expressão para eu fazer pode, nesse caso, ser substituída pela construção que eu fizesse (que + sujeito + subjuntivo).

Quanto ao sujeito de um infinitivo pessoal, lembramos que pode ser representado por um pronome, expresso ou implícito, ou um nome (um substantivo):

PORTUGUESE

$\left\{\begin{array}{l}\text { Ao sairmos (nós), } \\ \text { (quando nós sairmos) }\end{array}\right.$ os estudantes começaram a falar alto

\section{ENGLISH}

When + subject + verb [...]

(time clause)

When we left, the students began to talk loudly $\left\{\begin{array}{l}\text { so }+ \text { subject }+ \text { verb } \\ \text { for }+ \text { noun }+ \text { to }+ \text { inf }\end{array}\right.$

You ought to fertilize the land,

Você devia adubar a terra, para as árvores crescerem ${ }^{10}$ mais depressa. so the trees would grow more. for the trees to grow more.

\footnotetext{
${ }^{9}$ Há na linguagem popular alguma confusão entre os empregos usages (usos) em que o pronome é o objeto do verbo principal e aqueles em que ele é o sujeito do infinitivo. Quando o pronome segue o verbo principal, a forma de sujeito é freqüentemente, ouvida, substituindo a forma mais correta de objeto.

PORTUGUESE ENGLISH

Deixa eu fazer isso por Deixa-me fazer isso. Let me do that.

Mas o uso (use) de um pronome-objeto seguindo uma preposição, onde o sujeito do infinitivo deveria estar na forma nominativa é considerado fora do padrão. PORTUGUESE

ENGLISH

For + object / to + inf

Ele trouxe uma maçã para mim comer (subst) por He brought an apple for me to eat. para eu comer.

${ }^{10} \mathrm{O}$ infinitivo nesse caso é usado para expressar intenção.
} 
Além do sujeito, tanto o infinitivo pessoal quanto o impessoal, podem se fazer acompanhar de um objeto, direto ou indireto, representado respectivamente por um nome (substantivo) ou pronome:

PORTUGUESE

É urgente passar um telegrama.

Entrei à noite, sem ninguém $\underline{\text { me }}$

ver.
ENGLISH

[...] to + inf + object

It is urgent to send a telegram.

[...] prep + noun`s -ing form

(gen.case)+object

I came in at night, without anyone's

seeing ${ }^{11}$ me.

O infinitivo é ainda usado como complemento de verbo ou de nomes (substantivos ou adjetivos).

\subsubsection{Infinitivo complemento verbal}

Quanto ao verbo, às vezes o infinitivo completa-lhe diretamente o sentido, sem o auxílio de uma preposição, mas muitas vezes a preposição é exigida. A omissão ou escolha da preposição é determinada pelo verbo principal que precede o infinitivo.

O uso do infinitivo sem preposição ocorre com vários verbos comuns que não exigem uma preposição ${ }^{12}$. Eles incluem querer, dever, ir, vir, ver, ouvir, e vários outros, como segue:

\footnotetext{
${ }^{11}$ Em inglês, com um verbo depois de uma preposição, usa-se normalmente o gerúndio: He is fond of climbing. He insisted on seeing her. Por essa razão o verbo nominalizado torna a forma de gerúndio, pois ele está regido (dominated) pela preposição without.

${ }_{2}$ Em inglês, verbos tais como want, forget, promise, hope,_entre outros. requerem um infinitivo com to: He promised to obey me. We hope to start tomorrow. Mas verbos tais como must, can, may, let, make $e_{2}$ entre outros, são seguidos por um infinitivo sem to: you must study hard. She let me go.
} 


\section{PORTUGUESE}

Nós vamos passar nossa férias

em Santos.

Ouvimos os alunos cantarem no pátio
ENGLISH

$[\ldots]$ verb + to $+\inf [\ldots]$

We are going to spend our vacation in Santos.

$[\ldots]$ verb + noun +
-ing form $\{$ inf. without to

We heard the students $\left\{\begin{array}{l}\text { sing }^{13} \\ \text { singing }\end{array}\right.$

on the campus

Quanto aos infinitivos precedidos de preposição, ocorrem devido à regência dos verbos correspondentes com a função transitiva indireta. Muitos verbos podem receber qualquer uma de duas ou mais preposições antes deles. A seleção da preposição se dá usualmente para exprimir diferentes significados. Alguns verbos que não são normalmente seguidos por uma preposição passam a exigi-la; relacionando-se a outros verbos por meio dela em situações especiais.

Veja-se:

PORTUGUESE

\section{ENGLISH}

$[\ldots]$ verb + to $+\inf [\ldots]$

Ele acabou de ler o livro.

He finished to read the book.

Se a forma verbal acabou estiver enfatizada, a expressão acabou de ler adquire o significado de um ação recentemente concluída. Assim temos:

PORTUGUESE

Ele acabou de ler o livro.

Ele acabou por entrar em casa.

Ele veio a ser delegado de polícia.
ENGLISH

$$
\text { [...] have + just + past participle [...] }
$$

He has just read the book.

$[\ldots]$ verb + to $+\inf [\ldots]$

He finished by coming into the house.

$[\ldots]$ verb + to $+\inf [\ldots]$

He came to be a chief of police.

\footnotetext{
${ }^{13}$ Os verbos de sensação feel, see, hear, etc." recebem o infinitivo sem to, mas podem ser seguidos por uma forma em -ing: I heard her coming in ou I heard her come in. O infinitivo sugere que a ação esteja completa. A forma de gerúndio pode ser usada: completa e incompleta.
} 
A omissão ou escolha de uma preposição é, portanto, uma questão lexical que supõe adequada aprendizagem, pois a preposição exigida depende da regência do verbo seguido pelo infinitivo.

Nos casos de vamos passar e veio a ser registrados anteriormente devem ser consideradas duas situações diferentes na comparação do inglês com o português. Os verbos ir e vir, respectivamente em vamos passar e veio a ser, em inglês, são considerados funcionais e pedem um complemento considerado objeto direto (sem preposição) ou indireto (com preposição) o que não ocorre em português, em que tais expressões são consideradas locuções, portanto, seus elementos não se separam para fins de análise.

\subsubsection{Infinitivo complemento nominal}

Quando complemento de substantivos e de adjetivos, o infinitivo, a eles se relaciona sempre por meio de uma preposição. A preposição mais comum é de, mas alguns substantivos e muitos adjetivos exigem uma outra (além de de) ou permitem uma escolha entre algumas preposições, conforme:

\section{PORTUGUESE}

Tenho medo de ficar em casa à noite.

Estou pronto para começar.

Há entre eles um tendência a se

declararem livres.

\section{ENGLISH}

$[\ldots]$ adjective + to $+\inf [\ldots]$

I am afraid to remain at home at night.

I am ready to start.

$[\ldots]$ noun + to + inf $[\ldots]$

There is among them a tendency

to declare themselves free. 


\subsubsection{Infinitivo outras possibilidades de ocorrência}

Em acréscimo aos usos anteriormente apresentados, o infinitivo funciona em orações reduzidas com valor de adjetivo. E, depois de o primeiro, o segundo, entre outros, e às vezes depois de superlativos, o uso do infinitivo corresponde a uma oração subordinada adjetiva relativa (cláusula relativa) também em sua forma reduzida, como em:

\section{PORTUGUESE}

O ultimo (homem) a sair do navio.

(O ultimo (homem) que saiu/a sair [...])

A melhor peça a ser interpretada naquele ano.

(A melhor peça que foi interpretada [...])

\section{ENGLISH}

The last (noun) + to $+\inf [\ldots]$

The last (man) to leave the ship.

(The last (man) who left/leaves [...])

The best + noun + to +inf [...]

The best play to be performed [...]

(The best play that was performed [...])

Como substituto do gerúndio o infinitivo se apresenta precedido pela preposição $a$.

Essa construção preposição $a$ + infinitivo é encontrada na escrita, mas não de maneira bastante ampla. Ela substitui o gerúndio sem provocar alteração do significado original, conforme se verifica em:

PORTUGUESE

Estou a falar.

(Estou falando.)

\section{ENGLISH}

[...] be + ing [...]

I am speaking.

[...] noun + ing form [...]

I saw a dog barking after a cat.

Vi um cão a latir atrás de um gato.

(Vi um cão latindo ${ }^{14}$ atrás de um gato.

\footnotetext{
${ }^{14}$ As formas de gerúndio e infinitivo que vêm depois de substantivos podem ser chamadas de modificadores do nome. Nesse caso o modificador do nome latindo é corresponde à redução de uma cláusula relativa (oração subordinada adjetiva). PORTUGUESE ENGLISH

Vi um cão, que estava latindo atrás de um gato. I saw a dog, which was barking after a car.
} 
Como alternativa a cláusulas subordinadas com verbo no indicativo, as construções a seguir, tanto nas suas formas reduzidas de infinitivo como nas suas correspondentes desdobradas são normalmente usadas, mas a construção clausal subordinada desdobrada ocorre com maior freqüência. A exemplo de:

PORTUGUESE

Creio ser o último a chegar.

Creio que sou o último a chegar

João nos contou isso
ENGLISH

$\left\{\begin{array}{l}\text { Subject }+ \text { verb (that) subject }+ \text { verb }[\ldots] \\ \text { I think (that) } \underline{\text { am }} \text { the last to arrive. }\end{array}\right.$

$[\ldots]$ as + subject + verb $[\ldots]$

John told us that as we left the party.

\{

ao sairmos da festa.

quando saímos da festa.

Como alternativa a cláusulas subordinadas com verbo no subjuntivo, em um grande número dos casos as construções infinitivas e clausais estão em freqüente uso quer nas formas faladas e escritas da linguagem.

PORTUGUESE

É imprescindível \{

partirmos já.

que partamos já.

Amanhã mandarei

\section{ENGLISH}

$[\ldots]$ for + pron + to $+\inf [\ldots]$

It is absolutely necessary for us to

leave now.

[...] will have + object + past participle

Tomorrow I will have the shoes

repaired.

que consertem

os sapatos

\footnotetext{
${ }^{15}$ Em muitas expressões o infinitivo ativo pode ter força passiva, ou pode ser interpretado quer como ativo ou passivo.

PORTUGUESE

ENGLISH

Ele mandou consertar os sapatos (= que alguém) He had the shoes repaired. consertasse ou que fossem consertados.

Não há nada a fazer (= a ser feito)

There is nothing to do (= to be done)
} 
Freqüentemente o infinitivo é a forma verbal usada em sintagmas adverbiais introduzidos por uma preposição ou locução prepositiva ou em orações subordinadas adverbiais finais reduzidas.

PORTUGUESE

Estou cansado antes de comecar o trabalho.
ENGLISH

[...] prep + ing form (verb) [...]

I am tired before beginning the work.

$[\ldots]$ so + noun + veb $[\ldots]$

for + noun + to $+\inf [\ldots]$

Vamos levar uns presentes, para os Let's take some presents,

meninos não ficarem decepcionados.

[...] para que os meninos não fiquem so the children won't be disappointed.

for the children not to be disappointed. decepcionados.

Cabe lembrar a existência de expressões especiais formadas com o infinitivo.

Essas expressões não se encaixam em nenhum dos padrões anteriormente mencionados, mas se achem presentes com bastante freqüência nos discursos para fins de comunicação.

São elas:

1.Ter que e ter de seguidos de infinitivo

Essas expressões intercambiáveis, denotam obrigação de realizar a ação nomeada pelo infinitivo, como em:

PORTUGUESE

Tenho que (ou de) pagar a conta, sem
ENGLISH

[...] must $+\inf [\ldots]$

I must pay the bill, without fail. falta.

\section{Terpara}

O uso de um verbo, mais freqüentemente ter com um objeto nominal, seguido de para e o infinitivo, indica que a ação representada pelo infinitivo deva ser realizada sobre o substantivo (nome): 
PORTUGUESE

Ela não tem sapatos para usar.
ENGLISH

$[\ldots]$ noun $($ object $)+$ to $+\inf [\ldots]$

She has no shoes to wear.

\section{Por e o infinitivo}

Neste caso a ação está ainda para ser realizada. Essa ação não realizada, na língua inglesa, é representada pelo particípio, diferença bastante significativa entre as duas línguas, como se observa em:

PORTUGUESE

Ele tem uma casa nova, mas por

pintar.

\section{ENGLISH}

noun (object) [...] still un + past

participle.

She has a new house, but still

unpainted.

\section{Sem e o infinitivo}

Essa preposição seguida de infinitivo pode denotar que a ação não foi realizada e possivelmente nunca se realizará. Esse uso corresponde a outra diferença significativa: o infinitivo em português corresponde ao particípio do inglês, como a seguir.

PORTUGUESE

O milho ficou sem cultivar.

\section{ENGLISH}

[...] remain un + past participle

The com remained uncultivated $^{16}$.

Apesar de o infinitivo em português ter uma forma correspondente em inglês, podemos dizer que existem em Inglês diversas maneiras de se expressar os infinitivos do português. Uma das correspondências inglesas mais freqüentes é a forma de -ing, que acaba se estendendo aos substantivos (nomes) e deverbais do português. Várias outras construções inglesas serão apresentadas no próximo capítulo através das inúmeras abordagens apresentadas pela análise contrastiva.

Dando continuidade à seqüência inicialmente prevista passamos a abordagem dos modificadores do nome.

\footnotetext{
16 Não é raro encontrarmos em inglês uma forma verbal passiva construída, com particípio passado, correspondendo a um infinitivo em português, como em:

Disks may be made even more efficient [...]

Discos podem se tornar ainda mais eficientes [...]
} 


\subsubsection{Modificadores do nome}

Quando se fala em língua, tem-se a idéia de que o termo somente se refere ao meio de comunicação de um determinado povo. Entretanto, lembramos que língua tem sentido mais amplo: mostra não só a capacidade humana de atualizar cadeias de palavras que o indivíduo automatizou - e da qual ele se utiliza para comunicar-se com pessoa de mesma nacionalidade - como também traz em nível subjacente uma manifestação do pensamento, comum a todos os povos. A noção de língua não deverá estar restrita àquilo que se ouve ou que se lê.

Deve-se levar em consideração que o pensamento, quando é atualizado, traz consigo uma roupagem característica de um determinado idioma. O trabalho de um lingüista deverá ser o de desvendar o que existe de básico numa seqüência de palavras consideradas gramaticais, procurando, assim, um universalismo entre as línguas. É essa a preocupação da gramática transformacional: parte-se de uma idéia básica central, que vai sendo revestida de transformações até que esteja pronta para ser incluída dentro de uma aceitabilidade e uma gramaticalidade lingüísticas. Os transformacionalistas consideram, portanto, que a língua é composta de infinitas seqüências de palavras, chamadas orações, que passaram por três fases.

- Estrutura profunda: traz as idéias básicas e claras de uma oração.

- Estrutura intermediária: recebe transformações até chegar à terceira fase.

- Estrutura superficial: configura o resultado dessas transformações.

Para melhor compreensão desses fenômenos lingüísticos, considerem-se as orações:

1. I think he is a diligent pupil.

2. There was a broken watch on the table.

3. The approaching train is half an hour late.

4. The singing girl was dressed in red.

5. I found Peter's car outside the garage.

6. We have a four-door car.

7. They were listening to a political speech.

8. She is an army nurse. 
Os termos em negrito modificam os substantivos encontrados logo depois deles, restringindo-os, qualificando-os. São chamados modificadores do nome.

As orações subordinadas adjetivas encontradas em 1 e 8 sofreram todas as transformações necessárias, localizadas na estrutura profunda, agora representada pelo modificador.

Consideremos as orações:

1. I think he is a pupil, who is diligent.

2. There was a watch, which was broken, on the table.

3. The train which is approaching is half an hour late.

4. The girl who was singing was dressed in red.

5. I found the car which is Peter's outside the garage.

6. We have a car, which has four doors.

7.They were listening to a $\left\{\begin{array}{l}\text { which was political speech, } \\ \text { which deals with public affairs }\end{array}\right.$ which deals with public affairs in general

8.She is a nurse, who works for an army.

As orações subordinadas adjetivas encontradas em 1, 2, 3, 4, 5, e 7 foram formadas introduzindo-se uma forma do verbo to be que corresponde ao verto ser. Contudo, isso nem sempre poderá ocorrer; dependerá da possibilidade de o modificador funcionar como predicativo ou não. Nesse caso, deve-se representá-lo por uma oração que Ihe dê uma correspondência semântica satisfatória, como acontece em 6 e 7 . As seguintes frases $\left(^{*}\right)$ ficariam, então, agramaticais.

${ }^{*} 6$. We have a car, which is four door.

${ }^{*} 8$. She is a nurse, who is an army.

As sentenças 3, 4 e 5 apresentam, respectivamente, os substantivos train, girl, car precedidos do artigo definido the. Para alguns autores, as orações subordinadas adjetivas encontradas logo após esses substantivos não vêm se referindo propriamente a eles, mas especificando o artigo definido ${ }^{17 .}$

Considerando tal fato em português, encontramos problemas semelhantes, com algumas restrições.

\footnotetext{
${ }^{17}$ Um dos autores que defendem tal fato é John Bowers (1966) em seu Adjectives and Adverbs in English.
} 
Sejam observadas as sentenças:

1A. Acho que ele é um aluno inteligente.

1B. Acho que ele é um aluno, que é inteligente.

Comparando essas duas orações, vê-se que em 1B está destacada a oração subentendida em $1 \mathrm{~A}$, no adjetivo inteligente, modificador de aluno. Essa oração está expressa na estrutura profunda a qual, depois de sofrer transformações de apagamento (chamadas em inglês relative clause reduction transformation), vai reduzir-se a uma estrutura superficial representada por um adjetivo.

Em português, o que se denomina por a adjectival shift transformation quase não acontece, portanto, o adjetivo permanece na sua posição pós-nominal. Rodrigues Lapa (1975) explica que o adjetivo tanto poderá vir depois do substantivo e, nesse caso, tende a conservar o valor próprio, objetivo, como antes do termo modificado, tendendo a perder o próprio valor e a adquirir um sentido afetivo: Aquela menina é uma inteligente aluna.

Sejam analisadas as seguintes sentenças:

2A. Na mesa havia um relógio $\left\{\begin{array}{l}\text { quebrado. } \\ \text { que estava quebrado. }\end{array}\right.$

2B. Havia, na mesa, um relógio, que foi (estava) quebrado.

$2 \mathrm{C}$. Havia na mesa um quebrado relógio.

3 A. * O trem se aproximando ${ }^{18}$ está meia hora atrasado.

18 Considera-se a sentença $3 \mathrm{~A}$ agramatical, pois, quando o gerúndio aparece sozinho, em lugar de uma sentença, ele tem, às vezes, valor de oração subordinada adverbial temporal; outras, de adjunto adverbial de modo. Nunca apresenta, porém, valor de oração subordinada adjetiva, embora o fato de ela encontrar-se sem vírgulas possa admitir sua função de modificadora, porque faz parte integrante da frase nominal $\boldsymbol{O}$ trem. Os exemplos seguintes poderão esclarecer melhor:

A menina, chorando, saiu da sala. Isso significa: A menina saiu da sala, chorando (de modo choroso advérbio de modo), ou então, A menina saiu da sala enquanto chorava (oração subordinada adverbial temporal). O estudante, passeando, encontrou uma pulseira de ouro. Dessa sentença pode-se ainda encontrar as seguintes possibilidades: a) $\mathrm{O}$ estudante encontrou uma pulseira de ouro, passeando (modo ou tempo). b) $O$ estudante encontrou uma pulseira de ouro enquanto passeava (tempo).c) $O$ estudante, passeando (modo ou tempo), encontrou uma pulseira de ouro. As três possibilidades não contemplam a inglesa, ao pé da letra, uma vez que não existe em português o adjetivo correspondente: the walking studant>o estudante passeante.

Há casos, ainda, em que a relação das palavras pode causar nuances de má interpretação.

Considere as orações:

She is a fast servant.

$\mathrm{He}$ is a hard boss student.

Como vemos a palavra fast e har" parecem funcionar como verb modifies.

Há casos, ainda, em que a relação das palavras pode causar nuances de má interpretação.

Considere as orações: 
3B. O trem que está se aproximando está meia hora atrasado.

4A. * A garota cantando está vestida de vermelho.

4B. A garota que está cantando está vestida de vermelho.

5A. Encontrei o carro de Pedro fora da garagem.

5B. Encontrei o carro que Pedro possui fora da garagem.

5C. ${ }^{*}$ Encontrei de Pedro o carro fora da garagem.

6 A. Nós temos um carro de quatro rodas.

$6 \mathrm{~B}$. Nós temos um carro, que tem quatro rodas.

$6 \mathrm{C}$. ${ }^{*}$ Nós temos de quatro rodas um carro.

7A. Nós estávamos ouvindo um discurso político.

7B. Nós estávamos ouvindo um discurso que era político.

7C. *Nós estávamos ouvindo um político discurso.

$8 \mathrm{~A}$. Ela é uma enfermeira das forças armadas.

8B. Ela é uma enfermeira, que trabalha nas forças armadas.

8C. Ela é uma das forças armadas enfermeira.

Analisem-se as orações em inglês:

A. The hall door was decorated with $[\ldots]$

$B$. There is a street lamp just [...]

C. They're talking about the London transport [ ...]

D. He spent his summer holidays in [...]

E. I love reading adventure stories $[\ldots]$

F. University seniors will be invited to attend that lecture.

G. The school doctor was graduated in Chicago.

$H$. That man married a movie star. 
Ao buscar as orações relativas implícitas, tem-se o seguinte:
A. The door

$$
\left\{\begin{array}{l}
\text { of the hall was decored wih [...] (implícita) } \\
{ }^{*} \text { which is of the hall. } \\
{ }^{*} \text { which the hall owns } \\
\text { which opens on to the hall }
\end{array}\right.
$$

B. There is a lamp,

*which is of the street just [...]

which stands on the street. which is found on the street.

C. They're talking about the transport

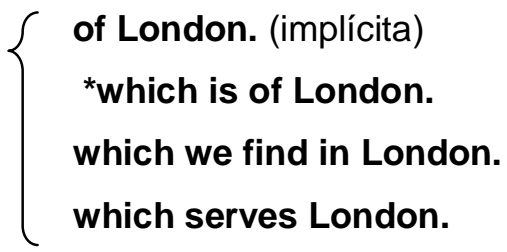

D. He spent his holidays $\left\{\begin{array}{l}{ }^{*} \text { which were of the summer }[\ldots] \\ \text { which were taken in summer }[\ldots]\end{array}\right.$

F. Seniors $\left\{\begin{array}{l}\text { of the University will be invited [...] } \\ { }^{*} \text { who are of the University [...] }\end{array}\right.$

G. The doctor $\left\{\begin{array}{l}\text { of the school was graduated }[\ldots] \\ { }^{*} \text { who is of the school. } \\ \text { who works at school. }\end{array}\right.$

H. That man married a star $\left\{\begin{array}{l}{ }^{*} \text { who is of the movie. } \\ \text { who appears in the movies. } \\ \text { who appears in films. }\end{array}\right.$

As sentenças que não trazem 0 asterisco $\left(^{*}\right)$, caracterizador de agramaticalidade, inadequação ou ambigüidade, são consideradas ou gramaticais ou coloquiais (implícitas), porque entre o modificador do nome e o nome da estrutura superficial existe uma relação semântica que coincide com o significado das orações subordinadas adjetivas encontradas nas estruturas subjacentes, geralmente 
indicando posse. Em inglês o 's equivale ao genitivo latino, indicador de posse cuja representação através do 's não existe em português ${ }^{19}$.

Em português é normal encontrar um substantivo modificando outro através de locuções adjetivas, isto é, as formadas por preposição + substantivo, um sintagma preposicionado, com função de modificador. Observem-se as orações:
A. O carro de Ana foi roubado.
B. Costumavam ficar em casa em dias de chuva.
C. O jovem demonstrava inclinação pela ciência.
D. Aquele líder deu ao povo uma impressão de força e poder.
E. Nossa prima tinha desconfiança de tudo.
F. Pedro tem força de Hércules.
G. Tio Joaquim chegou às seis horas.
H. Era uma noite sem estrelas.
I. Não há nenhum livro sem capa na biblioteca daquele mestre.
J. Ela irá receber o seu salário-família.
L. Ele foi meu colega de turma.
M. Os alunos se achavam bem à frente de uma bandeira do Brasil.

Ao se buscarem as orações subordinadas adjetivas subjacentes deste modificadores, encontrar-se-á o seguinte:
A. O carro
que é de Ana foi roubado. que Ana possui foi roubado. que pertence a Ana foi roubado.
B. Costumavam ficar em casa em dias $\left\{\begin{array}{l}\text { que eram de chuva } \\ \text { que estavam chuvosos }\end{array}\right.$

C. O jovem demonstrava uma inclinação $\left\{\begin{array}{l}\text { que está ligada à ciência. } \\ \text { que é científica. }\end{array}\right.$

\footnotetext{
19 Nas expressões to-day's paper e a week's holiday encontramos um tipo de noun modifier que traz a característica 's' não para indicar o possuidor, mas sim por ser comum o uso de forma de possessivo com expressões de tempo como essas.
} 
D. Aquele líder deu ao povo uma impressão $\left\{\begin{array}{l}\text { que é de força e poder. } \\ \text { que é forte e poderosa. } \\ \text { que é esta: ele tem } \\ \text { força e poder. }\end{array}\right.$

E. Nossa prima tinha desconfiança que é de tudo. que abrangia tudo. que era ligada a tudo.

F. Pedro tem força, que é de Hércules. que Hércules tinha. que é hercúlea. que é semelhante à de Hércules.

G. Tio $\left\{\begin{array}{l}\text { Joaquim chegou às seis horas. } \\ \text { que é o Joaquim, chegou às seis horas. }\end{array}\right.$

H. Era uma noite, que estava sem estrelas. que estava escura. que não tinha estrelas.

I. Não há nenhum livro,

( que está sem capa, na biblioteca daquele mestre. que está desencapado, na biblioteca daquele mestre. que não tem capa, na biblioteca daquele mestre.

J. Ele irá receber o seu salário $\left\{\begin{array}{l}{ }^{*} \text { que é família. } \\ \text { que é para o sustento da família. }\end{array}\right.$

L. Ele foi meu colega, $\left\{\begin{array}{l}\text { que estudou na mesma turma. } \\ \text { que pertencia à mesma turma. }\end{array}\right.$

M. Os alunos se achavam bem à frente de uma bandeira, $\left\{\begin{array}{l}\text { que é do Brasil. } \\ \text { que é brasileira. }\end{array}\right.$

Ao serem desdobrados, todos os exemplos dados apresentam uma oração subordinada adjetiva, esclarecedora do valor semântico de modificadores formados 
por preposição+substantivo, como: de Ana, de chuva, pela ciência, de força e poder, de tudo, de Hércules, sem estrelas, sem capa, de turma e do Brasil.

Alguns desses modificadores podem transformar-se em um simples adjetivo, como acontece em de Hércules (hercúleo), de chuva (chuvosa), ligada à ciência (científica).

\subsubsection{Modificadores do nome: casos específicos}

Há modificadores de nome com funções especiais que irão depender, ora da sua colocação na frase, ora dos traços dos nomes a que se atrelam. Isso acontece quando a expressão apresentar dois modificadores, sendo que um aparece, normalmente, indicando posse e o outro em forma de adjunto adnominal ou como complemento nominal.

Observe-se que as expressões assinaladas com (*) são inadequadas ou ambíguas:

1A. Uma anciã de costumes simples.

1B. *Uma anciã simples de costumes.

2A. Uma jovem vermelha de vergonha.

2B. * Uma jovem de vergonha vermelha.

3A. Um doente curioso de notícias.

3B. *De notícias um doente curioso.

4A.Um homem de estatura média.

4B. *Um homem médio de estatura.

$5 \mathrm{~A}$ Um chefe duro de coração.

5B. Um chefe de coração duro.

6A Um edifício de vitrines cheias.

6B. Um edifício cheio de vitrinas. 
7 A. Uma história longa de expor.

7B. * Uma história de expor longa ${ }^{20}$.

\subsubsection{Modificador: de+substantivo}

O caráter adjetivo da forma de + substantivo é comum aos genitivos latinos de procedência e de matéria:
A. Um médico da Espanha.
Um médico espanhol.
B. Uma senhora da França.
Uma senhora francesa.
C. Uma montanha de rochas
Uma montanha rochosa.
D. Um campo de flores.
Um campo florido.

Há casos, porém, em que o adjetivo apresenta uma função especializada:
A. Uma torta de açúcar. $\neq$ Uma torta açucarada.
B. Um pão de água. $\quad \neq$ Um pão aguado.

\subsubsection{Modificador secundário: particípio}

Quando o termo secundário for um particípio, podem ser encontrados problemas que deverão ser bem observados.

\footnotetext{
${ }^{20} \mathrm{Em}$ Complementos del genitivo, John Wonder chama o termo modificado de termo primário e o modificador, de termo secundário, portanto, para ele, a palavra homem, em 4 A, é um termo primário; o complemento precedido da preposição de, em de estatura, termo secundário, e o adjetivo médio, termo terciário.

Em espanhol, segundo Wonder, quando o complemento for um infinitivo, o termo terciário poderá, às vezes, modificar tanto o termo primário quanto o secundário. Observem-se as expressões:

Una historia de contar largo.

Una historia larga de contar.

Nas sentenças seguintes, não acontece o mesmo:

Una tarea de hacer dificil

Una tarea dificil de hacer.

A expressão Um homem de uma inteligência! já traz em si o modificador subentendido pela idéia exclamativa.
} 
Analisem-se as expressões:
A. Um banco feito de madeira.
B. Um caminhão carregado de frutas.
C. Um tanque cheio de gasolina.
D. Um ladrão crivado de balas.
E. Um presidente amado do povo.
F. Uma senhora avançada de idade.
G. Um menino crescido de corpo.

As expressões de A a D não admitem dupla aplicação do termo secundário. As inversões só seriam possíveis nas três últimas; a $\mathrm{F}$ tem até uma estrutura melhor, mas convém observar que a $E$ passaria a ter outro sentido.

De $A$ até $E$ há particípios passados de verbos transitivos, embora em $\mathrm{C}$ se encontre a palavra cheio usada só como adjetivo.

Pelas orações de $A$ a $G$ vemos que os modificadores precedidos de de, termos terciários, completam o sentido que falta aos particípios passados, termos secundários.

Em A encontramos a preposição de precedendo um modificador que traz a idéia de matéria; em $\mathrm{B}, \mathrm{C}$ e $\mathrm{D}$, a idéia de instrumento; em $\mathrm{E}$ a preposição de indica o agente da passiva.

Particípios de verbos intransitivos ou usados intransitivamente formam com freqüência expressões que carregam idéia de referência, é o caso da $F$ e G.

É importante destacar que, se retirarmos os termos secundários de $A, B$ e $C$, as expressões não sofrerão alteração de sentido.

Observemos o seguinte:
A. Um banco (feito) de madeira.
Um banco de madeira.
B. Um caminhão (carregado) de frutas.
Um caminhão de frutas.
C. Um tanque (cheio) de gasolina.
Um tanque de gasolina.

O mesmo não acontece com as outras expressões que sofrerão ora falha, ora uma alteração completa de sentido, como é o caso de: ladrão (crivado) de balas. que difere de ladrão de balas. 
Considerando tais problemas em inglês e mantendo-se o asterisco para as construções agramaticais, inadequadas ou ambíguas, tem-se:

$1 \mathrm{~A} . \mathrm{He}$ is a man of average height.

1B. ${ }^{*} \mathrm{He}$ is a man average of height.

2A. *A building of full store-windows.

2B. * A building full of store-windows.

3A. *A girl red with shame.

3B. A girl with red shame.

4A. *A hard to do homework.

4B. A homework hard to do.

4C. ${ }^{*}$ Homework to do hard.

5A. A man of high intelligence ${ }^{21}$

5B. * A man high of intelligence

6A. A long story to tell.

6B. *A story to tell long.

6C. A story long to tell.

${ }_{21}$ Buscando as orações subordinadas adjetivas profundas desta estrutura,teremos o seguinte: $A$ man has intelligence. The intelligence is high, dando na superficial diferentes possibilidades: a) $A$ man of high intelligence; e, considerando-se que o adjetivo é modificador do substantivo e o advérbio, modificador do adjetivo, se o substantivo, nessa estrutura, se transformar em adjetivo, o adjetivo primeiro irá normalmente se transformar em advérbio, daí termos outras estruturas possíveis: A man who highly intelligent. ? b) A highly intelligent Man. Encontramos freqüentemente tais expressões nas língua portuguesa e inglesa, apresentando variações sintáticas coincidentes, embora haja, às vezes, necessidade de subentender termos que venham provar melhor o uso da norma padrão, ou seja, gramatical.

Ele é compreensivo.

Ele é de (grande) compreensão.

Ele tem (muita) compreensão.

Ele é político.

Ele é homem de política.

Ele tem política. (no que fala)

Paulo é belo.

Paulo é de (excessiva) beleza.

Paulo tem beleza.

Ele é cuidadoso.

Ele é (pessoa) de (muito) cuidado.

Ele tem cuidado.

He's understanding.

He's a man of understanding.

${ }^{*} \mathrm{He}$ has understanding.

He's a political man.

He's a man of politics.

* He has politics.

Paul is beautiful.

* Paul is of beauty.

Paul has beauty.

Paul is careful.

* Paul is of care.

* Paul has care

Como vemos, é muito comum em Português encontrarmos modificadores formados de prep +_substantivo, usados em lugar de um adjetivo: Homem de juízo (ajuizado). Homem sem juízo (desajuizado).Em inglês é mais comum encontrarmos substantivos exercendo tais funções: Paper Money. Rubber bands. 
7A. A chief with a wicked heart.

7B. * A chief wicked with a heart.

Como se pode observar nessas orações, parece não ser possível, em inglês, que um mesmo modificador possa funcionar como termo secundário e terciário, dando às orações um mesmo significado. Há, porém, alguns casos que permitem alguma semelhança com o português. Nas expressões $2 \mathrm{~A}$ e $2 \mathrm{~B}$, encontramos a palavra full funcionando como termo secundário e terciário. Tal possibilidade dá às frases significados completamente diferentes. Nas 3A e 3B, aparece um caso bem semelhante ao da língua portuguesa, em que o problema não mais é sintático: é semântico. As expressões 4B, 4C, 5A, 5B, 6A, 6B e 6C, apresentam possibilidades estruturais bastante semelhantes às do português.

Consideremos agora as seguintes expressões:
A. A bench made of wood.
$\rightarrow \quad$ A bench of wood.
B. Bands made of rubber.
$\rightarrow \quad$ Bands of rubber.
C.A truck full of fruit.
$\rightarrow \quad$ A truck of fruit.
D.A tank full of gas.
A tank of gas.
E. A thief full of bullets.
${ }^{*} A$ thief of bullets.
F. A president loved by the people.
A president by the people.
G. A lady advanced in age.
$\rightarrow \quad$ * $A$ lady in age.
H. A well developed boy
$\rightarrow \quad{ }^{*} A$ well boy

Essas expressões apresentam problemas semelhantes aos de português: as expressões $A$ e $B$ poderão existir sem os particípios, uma vez que suas idéias já estão contidas no modificador, indicador de matéria. O mesmo acontece com a $\mathrm{C} \mathrm{e}$ $\mathrm{D}$, que poderão permanecer sem adjetivo full, pois já se encontra subentendido no modificador que vem indicar nesse caso idéia de instrumento. O mesmo, porém, não acontece com a $\mathrm{C}, \mathrm{F}$ e G, que exigem a presença do particípio, pois nessas estruturas os modificadores of bullets, by the people e in age se referem diretamente a eles e não ao termo primário thief, president e lady, isto é, são indispensáveis, por 
não estarem contidos no modificador. O modificador of wood da A apresenta uma forma adjetiva correspondente: bench of wood. $\rightarrow$ Wooden bench ${ }^{22}$.

As expressões B e D apresentam um caso bastante comum na língua inglesa: o modificador, ao sofrer a adjectival shift transformation, perde a preposição, ficando nele subentendido:
A. Bands of rubber.
Rubber bands.

B. A tank of gas.

A gas tank.

A expressão $\mathrm{H}$ traz como modificador um particípio — também indispensável - mas que não vem modificado por preposição + substantivo, mas sim por um advérbio.

\subsubsection{Modificador: gerúndio}

Quando o gerúndio estiver funcionando como modificador, a oração subordinada adjetiva não poderá sofrer redução. Quando a língua portuguesa tinha a forma de particípio presente, era possível a substituição da relativa por uma dessas formas, sem causar alteração no significado, como ocorre em:

As meninas que estavam fumando saíram da sala. corresponde a As meninas fumantes saíram da sala.

Hoje, porém, essa forma existe, mas não para indicar uma ação em andamento, mas para mostrar a ação ou profissão de alguém. Entende-se por

\footnotetext{
${ }^{22}$ Essa derivação chamada adjetivação de uma locução formada de prep + substantivo é muito comum em português:

Brinquedos de criança. $\quad \rightarrow \quad$ Brinquedos pueris

Navegação por meio do rio. $\quad \rightarrow \quad$ Navegação fluvial.

Que se faz no rio.

Escritor de muitas obras. $\rightarrow \quad$ Escritor operoso.

Que produz muitas obras. $\quad \rightarrow \quad$ História universal.
do universo.

História do universo.
Que abrange os sucessos

fundamentais de todas as nações.

Muitos substantivos não têm adjetivo que lhes corresponda: boneca de pano, cavalo de pau, rajadas de fogo, etc.
} 
fumante uma "pessoa que fuma"; viajante, uma "pessoa que viaja"; estrela reluzente, uma "estrela que reluz"),

2.2.3.5 Modificador: particípio

O mesmo que acontece com as formas verbais em -ing acontece com o past participle (particípio) em inglês, isto é, funcionam como modificadores do nome e podem às vezes se tornar verdadeiros adjetivos:

The broken watch is near the vase.

As orações profundas destas expressões mostram o seguinte:

A) Someone broke a watch.

B) A watch is near the vase.

Aplicando-se a transformação da passiva em A teremos:
A) A watch was broken.
B) A watch is near the vase.

Ao introduzirmos a $A$ na $B$, obteremos:

The watch the watch was broken is near the vase.

Através da identical noun phrase deletion e relative clause transformation, tem-se:

The watch which was broken is near the vase.

Com a relative clause reduction transformation, chega-se a: 
The watch broken is near the vase.

E, finalmente, a adjectival shift transformation resultará em:

The broken watch is near the vase.

Vê-se, assim, que o particípio, já em si um termo com característica passiva, consumada, modifica um elemento com o papel de paciente numa sentença. É, então, fácil observar tais problemas, que poderão, também, ser encontrados nas expressões:
A. The damaged bridge.
B. The crowded room.

O contrário acontece quando o modificador for um gerúndio: esse, pelo fato de ser uma forma representante de ação, talvez apareça normalmente modificando o agente da ação:
A. The girl who is singing.
The singing girl.
$B$. The horse which is running.
The running horse.

Há casos em que o gerúndio não vem indicar ação, mas sim finalidade:

\section{Living-room; bathing-room.}

Em português, tais expressões correspondem a uma forma de preposição + infinitivo ou substantivo:
A. Sala
de estar.
B. Roupão de banho.
C. Máquina de costura.
de costurar.

Quando um particípio estiver modificado por uma frase preposicionada, ele, como o gerúndio, terá de vir posposto ao nome que estiver modificando:

A. The watch broken in the accident. 
B. The bridge damaged by the explosion.

C. The room crowded with students.

Também em português, um modificador anteposto ao termo modificado tende a perder o próprio valor e a adquirir um sentido afetivo, subjetivo. Isso, porém, não pode acontecer quando o modificador for representado pelo particípio, caracterizador da passiva, pois se, nesse caso, temos a descrição de um fato realizado, consumado, objetivo, o modificador não poderá sofrer influências individuais, nem matizes de ênfase:

O relógio quebrado está perto do vaso.

* O quebrado relógio está perto do vaso. ${ }^{23}$

O gerúndio e o particípio, quando estiverem funcionando como modificadores, poderão aparecer modificados por um advérbio. Sejam observadas as estruturas:

A well ${ }^{24}$-written book.

A well-performed play.

A beautifully performed play.

A carelessly written book.

A sweetly singing girl.

A swiftly running horse.
$X \quad$ An ill-written book.

$X \quad$ An ill-performed play.

${ }^{23}$ As expressões abaixo vêm caracterizar melhor essa análise: The stone rolls.

The dog barks.

The girl loves fun.

The cat hunts mice.

The man writes poetry.

He saw the (...) dog \& The dog bites men.

Moths eat the rug.

A horse draws the cart.

The owners abandoned the house.

He saw the (...) dog \& Fleas bite the dog.

$\rightarrow \quad$ The rolling stone.

$\rightarrow \quad$ The barking dog.

$\rightarrow \quad$ The fun-loving girl.

$\rightarrow \quad$ The mouse-hunting cat.

$\rightarrow \quad$ The poetry-writing man

$\rightarrow \quad$ He saw the man-biting dog.

$\rightarrow \quad$ The moth-eaten rug.

$\rightarrow \quad$ The horse-drawn cart.

$\rightarrow \quad$ The abandoned house.

$\rightarrow \quad$ He saw the flea-bitten dog.

Convém observar que o paciente na sentença ativa se encontra precedido do artigo indefinido. Isso dá à palavra uma determinação que vem provar a realização da ação, uma das causas que leva o verbo a se apresentar numa forma de ação realizada, forma de particípio.

${ }^{24}$ Os advérbios well e seu oposto ill só aparecem modificando um particípio e vem ligado a ele por um hífen. 


\subsubsection{Modificadores posnominais}

Considere os exemplos a seguir:

A. What's the money necessary to build the school?

B. Those are the courses most important for you.

C. Do we have coffee enough for everyone?

D. The waitress, old and weary, sat heavily down.

E. The fellow waving drives a convertible.

F. We bought something new.

G. I met someone very strange.

$\mathrm{H}$. That is the man who sold me the car.

I. That is the man whose son is in my class.

$J$. This is the place where I lost my watch.

$L$. The time when he arrived is not known.

$M$. The reason why he didn't come was that he was sick.

$\mathrm{N}$. Take the street which goes to the right.

O. A jug, which was from India, got broken.

P. Language, which is a process of communication, is an activity characteristic of mankind.

Q. Ships that take people across the ocean are usually quite large.

R. A proof that this problem is unsolvable will be given.

$\mathrm{S}$. He has the idea that he is a great linguist.

T. Here is the Martini that you asked for.

A colocação posnominal do modificador também acontece com adjetivos comuns quando eles estiverem modificados por uma frase. É o que acontece com as A e B.

O período $\mathrm{C}$ traz o modificador depois de coffee, por estar ele modificado por for everybody, mas caso a resposta seja No, we don't have enough coffee, então, voltará ao seu lugar normal: terá uma colocação pré-nominal.

O modificador em forma de aposto encontrado na $D$ parece trazer grande carga enfática, chegando até a propor uma idéia de causa: As the waitress was old and weary, she sat heavily down, o que não aconteceria se o modificador viesse antes: The old and weary waitress sat heavily down. 
No exemplo $E$, encontra-se um caso bastante característico. Buscando a estrutura profunda, tem-se: The fellow drives a convertible. The fellow is waving > The fellow who is waving drives a convertible. A posição do modificador se justifica por deixar a oração subordinada adjetiva (reduzida do gerúndio) mais evidente, acentuando a idéia de restrição. Encontramos ainda outro fator importante: se o termo waving viesse antes do nome, ele passaria a transmitir uma idéia que permanece, como nas expressões: waving flags, waving movements, o que daria à frase uma total quebra de significado. Note-se que a adjectival shift transformation particulariza o termo modificado, transformando-o num elemento com outro sentido; isso evidentemente não poderia acontecer se houvesse elementos sem características que admitissem tal possibilidade. Pelas expressões encontradas em $\mathrm{F}$ e G, vê-se que o mecanismo é admissível, talvez pelo fato de o termo modificado ser um indefinido.

Nas orações $\mathrm{H}, \mathrm{I}, \mathrm{J}, \mathrm{L}, \mathrm{M}, \mathrm{N}, \mathrm{Q}$ e T, são encontrados nomes modificados por orações subordinadas adjetivas, que não podem sofrer relative clause reduction transformation. O período T poderá ficar com o pronome relativo that omitido. Esse processo já é bastante conhecido, quando uma oração subordinada adjetiva for introduzida por who, whom, which ou that e for seguida do sujeito da oração adjetiva, esses conectivos poderão ser eliminados. Os períodos $H$ a $Q$ apresentam conjunções exigidas pelos tipos de antecedentes lá encontrados: who e whose aparecem precedidos de pessoa: where, de local; when, de tempo; why, de causa ou razão e which, de ser inanimado, coisa.

Analisando-se as orações $\mathrm{O}$ e $\mathrm{P}$, nota-se que poderão reduzir-se-á:

$\mathrm{O}_{1}$ - A jug, from India, got broken.

$\mathrm{P}_{1}$ - Language, a process of communication, is an activity characteristic of mankind.

Essas duas orações apresentam modificadores que não podem sofrer a shift transformation: a $\mathrm{O}_{1}$ por apresentar um modificador iniciado por uma preposição e $\mathrm{P}_{1}$ por ser um aposto.

As sentenças $R$ e $S$ não apresentam modificadores representados por orações subordinadas adjetivas, mas sim por uma nominalização introduzida por that.

Em português, tais nominalizações têm outra representação estrutural:

Uma prova de que este problema é insolúvel será dada. 
Ele pensa $\left\{\begin{array}{l}\text { que é um grande lingüista. } \\ \text { ser um grande lingüista. }\end{array}\right.$

Quando um modificador em inglês corresponder a uma oração subordinada adjetiva, ele virá, em geral, imediatamente após o termo referido.

As sentenças $\mathrm{O}$ e $\mathrm{R}$, porém, parecem apresentar outras variações estruturais aceitáveis:

$\mathrm{O}_{2}$. A jug got broken, which was from India.

$R_{1}$. A proof will be given that this problem is unsolvable.

Conclui-se que há vários modificadores representados por sentenças que, tendo ou não a possibilidade de se reduzirem, não admitem a shift transformation, por não haver um termo que possa representar integralmente a idéia contida em cada oração; isso acontece normalmente quando o modificador for iniciado por um conectivo que não pode sofrer supressão, por uma preposição e ainda em casos especiais.

2.2.3.7 Modificadores: palavras invariáveis

Considerando-se por base as expressões:
A. An inside job.
B. Her inmost thoughts.
C. Outside buildings and shops.
D. The floor below is rented.
E. The woman ahead is the cashier

As sentenças A, B, e C sofreram a shift transformation; isso parece ter ocasionado uma diminuição de carga semântica dos modificadores, dando-lhes um sentido genérico, indefinido, como se pode observar na análise dessas estruturas.

As sentenças $D$ e $E$ trazem um problema diferente. Pelo fato de os modificadores estarem, respectivamente, depois floor e de woman, parecem ter 
recebido uma carga de ênfase: The floor which is below; The woman who is ahead, que realça também a idéia que está representada pelo artigo indefinido que precede o elemento modificado.

Deve-se observar também que na oração $E$ há um modificador iniciado pelo prefixo a-. Pela estrutura profunda, The woman who is ahead is the cashier, vemos que a palavra ahead se encontra depois de um verbo de ligação; é muito comum em inglês uma palavra começar com a- e aparecer inserida depois do verbo de ligação. Quando isso acontecer em orações subordinadas adjetivas, elas só sofrerão redução e não shift, deverão, portanto, permanecer logo após o nome modificado.

\subsubsection{Modificadores: formas have e be}

Sejam analisadas as orações em destaque:

\section{A. The shelf which has some books on it.}

1B. The shelf which is with some books on it.

2A.The boy who has the red hat.

$2 \mathrm{~B}$. The boy who is with the red hat.
$1 A_{1}$ - The shelf having some books on it.

$1 B_{1}$ - The self with some books on it. $2 A_{1}$ - The boy having the red hat. $2 \mathrm{~B}_{1}$ - The boy with the red hat.

É bastante comum encontrar expressões com o verbo to have, quando indica posse ou companhia, que pode ser substituída por uma forma do verbo to be + with

3A. The man had a dog \& the man came. $=$ The man who had a dog came. $=$ The man with a dog came.

No caso acima, as estruturas $1 \mathrm{~A}, 1 \mathrm{~A}_{1}, 1 \mathrm{~B}$ e $1 \mathrm{~B}_{1}$ trazem o mesmo significado. Assim, é possível pensar nas seguintes probabilidades: Mary has the children with her. The children are English. = The children are with Mary. The children are English. = The children with Mary are English. 


\subsubsection{Modificadores: transitivos e intransitivos}

Comparem-se as estruturas:
A. He's tired.
$A_{1}$. He's tired of travelling.
B. he's happy.
$B_{1}$. She's happy about the trip.

Apesar de esses modificadores terem sentido completo, são às vezes usados transitivamente.

Em português, observa-se o mesmo problema:
a) A menina está cansada de escrever.
b) Ela estava feliz pelo resultado da prova.
c) Os conhecimentos são úteis a todos.

2.2.3.10 Modificadores: adverbiais

Os marcadores adverbiais restringem-se aqui aos indicadores de circunstâncias de lugar e de tempo

\subsection{De lugar}

Observem-se as orações:

A The boy near the truck is my brother. = The boy who is near the truck is my brother.

B. The man in the next room is German. = The man who is in the next_room is German. 
C. The jar on the shelf ${ }^{25}$ is filled with dates $=$ The jar that is on the shelf is filled with dates.

Nesse caso, há um advérbio de lugar funcionando como modificador, isto é, restringindo o substantivo que se encontra antes.

\subsection{De tempo}

As expressões em destaque trazem na estrutura subjacente uma expressão de tempo que, depois, se transformará numa forma com valor de advérbio:

A. The 5 o'clock train (the train which leaves at 5 o'clock)

$B$. The morning paper (the paper which comes out in the morning)

C. Today's paper (the paper which comes out today)

D. A week's holiday (a holiday which lasts seven days)

É comum em inglês uma forma de possessivo ser usada com expressões de tempo com função de modificador do nome, como é o caso da C e D.

Em português, tais modificadores seriam formados com a preposição de + um advérbio de tempo, que apresenta, às vezes, uma forma adjetiva correspondente (com função de adjunto adnominal), como é o caso da expressão B:

Jornal da manhã. (jornal matutino).

2.2.3.11 Modificadores: derivados de nomes (substantivos)

Analisem-se as orações:

\footnotetext{
${ }^{25}$ O período : The flowers in the vase are mine apresenta modificador formado com a preposição in. Casos como esse trazem em português normalmente um modificador formado com a preposição de: As flores do vaso são minhas. É muito comum encontrar em português exemplos de modificadores que trazem a idéia de posse, enquanto em inglês trazem a idéia de local: This is the most interesting language in the world: Esta é a língua mais difícil do mundo. The best pupil in the class: $O$ melhor aluno da classe.
} 

A. That's a red-feathered bird. (a bird which has red-feathers)
B. That's a hard-surfaced road. (a road which has a hard surface)
C. She is narrow-waisted girl. (The girl has a narrow waist)
D. She is a dark-eyed girl (the girl has dark eyes)
E. That's a cloth-covered chair. (a chair which has a cloth cover)
F. The triangle is a three-sided figure. (a figure that has three sides)

Nas sentenças $A, B, C$ e $D$, há um modificador composto por adjetivo + nome (substantivo) + sufixo -ed.

$\mathrm{Na}$ sentença $\mathrm{E}$, há um modificador composto por nome (substantivo) + nome (substantivo) + sufixo -ed.

$\mathrm{Na}$ sentença $\mathrm{F}$, há um modificador composto de numeral + nome (substantivo) + sufixo -ed.

Essas formas em -ed não podem ser chamadas de past participle, porque não estão baseadas em verbos.

Esse tipo de modificador apresenta uma característica física ou mental inerente ao seu substantivo. Seu significado pode bem ser expresso por uma sentença com o verbo have como se vê entre parênteses. Tomemos a sentença D como exemplo:

She is a dark-eyed girl (the girl has dark eyes)

\subsubsection{Modificador: numeral + substantivo no singular}

\section{Observem-se:}

A) I need an eight-foot ladder in order to reach the ceiling (a ladder which has a length of eight feet)

B) They have made a thousand-mile journey (a journey which has a length of a thousand miles)

Correspondendo a esses casos discutidos, tem-se, em português, um modificador composto de preposição + substantivo, também modificado ora por um 
numeral, ora por um adjetivo: garota de olhos azuis; pássaro de penas vermelhas; figura de três lados; escada de oito pés.

Há casos em que o modificador secundário é um verbo na forma de particípio que, por sua vez, vem modificado por uma expressão composta de preposição +substantivo: cadeira coberta de pano.

A partir da análise de todas essas possibilidades de modificadores do nome, observa-se que a distinção dada às palavras pela morfologia não é satisfatória; ela limita suas inúmeras probabilidades de função, pois, como foi exposto, o caráter morfológico de uma palavra sofre constantes influências sintático-semânticas. A sintaxe, ajudada pela semântica, pode revelar o caráter de uma palavra, símbolo desprovido na sua base (estrutura profunda) de qualquer roupagem, que é posteriormente fornecida por um environment, um contexto gerado por uma transformação (estrutra superficial).

A sintaxe e a semântica não só apresentam os valores categóricos das palavras, como também as moldam num todo-complexo, que é, depois de pronto, considerado gramatical.

Expostos os conceitos considerados básicos para a análise do material obtido através das entrevistas, passaremos à análise contrastiva a posteriori. 


\section{CAPÍTULO 3: ANÁLISE CONTRASTIVA A POSTERIORI}

Conforme previsto, daremos início à parte prática de nosso trabalho, uma análise e considerações sobre as palavras (aceitáveis e inaceitáveis, isto é, que se excluem), de acordo com a tipologia a seguir:

\subsection{TIPOLOGIA DE ERROS}

Estabelecidas as correspondências entre a Interlíngua e a Língua 2, de acordo com as classes de palavras e identificados os recursos utilizados pelos entrevistados a fim de se comunicarem em $\mathrm{L}_{2}$, as dificuldades encontradas passarão a ser agrupadas conforme sua natureza, adotando-se os critérios de relações lexicais — referências morfossintático-semânticas.

\subsubsection{Gerúndio}

Nesta parte apresentaremos e comentaremos os registros relativos ao uso do gerúndio, enquanto substantivo, adjetivo e verbo, sem desprezarmos seus empregos quando aleatório ou especial.

\subsubsection{Gerúndio substantivo}

Compensando um infinitivo ou um nome (substantivo) com funções tais como as de sujeito, complemento nominal e adjunto adverbial na $L_{2}$, o gerúndio pode ser observado nas ocorrências: 
F1 I "Eu acho que também aprendendo uma língua está muito psicolôgia."

$\mathrm{L}_{2}$ "Eu suponho que, além disso, aprender uma língua é muito psicológico."

ou "Eu suponho que, além disso, a aprendizagem de uma língua é muito psicológico."

e

F2 I "[...] agora eu deve dar os aulas pra você porque meu experiência aprendendo português."

$\mathrm{L}_{2} \quad$ "[...] agora eu já posso dar aulas para você pela minha experiência em aprender português."

ou "[...] agora eu já posso dar aulas para você pela minha experiência na aprendizagem do português."

Nos usos do gerúndio em substituição a verbos no infinitivo ou a substantivos cujas funções seriam as de sujeito ou de complemento nominal na $L_{2}$, essa forma verbal foi erroneamente transferida para o português em lugar do infinitivo, por uma equivocada associação com o sufixo -ing, que pode ser muitas vezes traduzido para o português através do -ndo. Apesar de o gerúndio da interlíngua das falas 1 e 2 ter duas formas correspondentes na $L_{2}$, com funções diferentes em cada uma das falas: na fala 1, na primeira correspondência encontramos um verbo no infinitivo aprender e na segunda um substantivo aprendizagem na função de sujeito e fala 2 , a primeira correspondência se faz com um complemento nominal - em aprender e na segunda com um substantivo aprendizagem, ambas correspondem mais adequadamente a um infinitivo em português. Numa segunda possibilidade de correspondência em $L_{2}$, nesses casos caberia uma nominalização através do substantivo aprendizagem, conforme registramos - uma estrutura gramaticalmente viável, apesar de apresentar um nível menos freqüente, mais esmerado, que poderia ser representada respectivamente pelas paráfrases: minha experiência na aprendizagem do português e a aprendizagem de uma língua é muito psicológico. Encontramos nessas falas dois casos de interferência, atribuída a um desencontro de regras, a saber: as formas verbais em -ing se equivalem, muitas vezes, ao infinitivo em português, embora sejam relacionadas pelos falantes estrangeiros, com freqüência, ao -ndo (gerúndio) por ser considerado como padrão do português pelas 
inúmeras possibilidades de uso, um leque de correspondências, com garantida gramaticalidade que se configura numa transferência direta, fato que não ocorreu nos mencionados exemplos, o que acabou gerando uma transferência negativa (uma interferência).

Caso idêntico se verifica na fala:

F1 I "[...] na Inglaterra nós temos o tradição mudando sua nome com você tem um casamento."

$\mathrm{L}_{2} \quad$ "[...] na Inglaterra nós temos a tradição de mudar [de (na) mudança] seu nome quando você se casa."

Em $L_{2}$ admitimos o sintagma a tradição de mudar ou de (na) mudança. Portanto, o uso do gerúndio mudando em lugar de de mudar ou de (na) mudança, para complementar o núcleo nominal tradição origina um sintagma mal estruturado.

Considerando agora falas 1 e 2 a seguir, observamos dois gerúndios em sintagmas adverbiais: o da primeira fala indicando circunstância de tempo e o da segunda, de modo:

F1 I "As pessoas do Conselho têm uma programa do português bom antes do viajando $[\ldots] "$

$\mathrm{L}_{2} \quad$ "O pessoal do Conselho oferece um bom programa de português antes de viajar (antes da viagem, antes de ir para lá) [...]"

e

F2 I "Fala português! Você vai aprender pelo falando, mas não verdade."

$\mathrm{L}_{2} \quad$ "Fale português! Você vai aprender falando (pela fala), mas (isso) não é verdade."

Nesses dois casos uma abordagem mais ou menos semelhante aos empregos anteriormente apresentados, só que desta vez com um agravante, pois a nominalização errada do -ndo (gerúndio) está explícita: aparece em uma palavra precedida pelo determinante 0 . A presença desse artigo caracteriza a possibilidade de existir um nome subentendido nas expressões, o que pode corresponder a uma nominalização, com forma legítima e aceitável, através dos respectivos substantivos viagem e fala, claramente destacados nas paráfrases antes da viagem e pela fala. 
Tais substantivos poderiam ficar teórica e gramaticalmente configurados nas estruturas: prep+artigo+subst e prep+artigo+deverbal.

É conveniente entender que, na fala 1, além de não se identificar no infinitivo uma forma passível de correspondência em português, não se reconhece também o substantivo viagem como um uso válido. Conseqüentemente, ocorre a opção pelo gerúndio, que por estar nominalizado reforça ainda mais a agramaticalidade do texto. É um tipo de condicionamento que chamamos de transferência negativa uma interferência.

Na fala 2, a escolha do gerúndio seria admissível, porém sem a presença do determinante 0 , encontrado na combinação pelo (per +0 ), cujo emprego desencadeou uma nominalização, pelo falando, estranha e inaceitável, o que seria evitado pelo uso do deverbal fala, como segunda opção

Apesar de o -ing, nas falas transcritas, poder corresponder também aos substantivos: aprendizagem, mudança, viagem e fala, e ainda de haver pertinência dessa classe de palavras em determinados contextos, ocorre o uso da forma terminada em -ndo, nominalizada pela presença do artigo 0 , como alternativa em desrespeito às transformações convencionais como as derivações sufixais e os deverbais, entre outras.

Verifica-se pelo exposto a atribuição da roupagem de um nome à forma verbal em -ndo (gerúndio). Trata-se de alternativa infundada - o recurso a uma palavra, no caso, um verbo com o sufixo -ndo, escolhida pela correspondência direta e freqüente com o -ing, com a intenção de usá-la como substantivo, da mesma maneira que acontece em inglês. A transferência dessa função para o português, constitui uma interferência gerada pelo desconhecimento das funções e classes correspondentes.

Outras referências relativas a esse problema merecem atenção.

Se ampliarmos o texto que acabamos de analisar, teremos:

F1 I As pessoas do Conselho têm uma programa do português bom antes do viajando e depois da [...] bem vai chegar você tem outro curso."

$\mathrm{L}_{2} \quad$ "O pessoal do Conselho oferece um bom programa de português antes de viajar (antes da viagem) e depois de chegar [...] aí na volta (quando você chega) você encontra outro curso." 
Em antes do viajando, além da nominalização absolutamente agramatical do gerúndio em português, justificada pela presença do artigo $o$, a qual tomou o lugar de uma forma mais correta, a do infinitivo viajar ou do substantivo viagem, como já comentamos, um outro problema se manifesta: uma relação direta com o -ing do inglês (o pensar em inglês) - before traveling - resultando em uma transferência negativa, a denominada interferência (antes do viajando).

Quanto à depois da [...] bem vai chegar, a palavra bem muito comum nos diálogos foi transferida do inglês well.

Em vai chegar criou-se um sintagma que não corresponde à estrutura verbal anterior, pois desrespeita-se a seguinte correlação: antes de viajarldepois de chegar (na volta). A falta de paralelismo nessas referências evidencia uma mistura de expressões formadas com gerúndio viajando e infinitivo chegar, o que deixa subentendida uma dificuldade não só no uso de gerúndio/infinitivo, como, também, na nominalização dos respectivos verbos que podem ser inferidos através de paráfrases das mencionadas expressões: antes da viagem (na ida)/depois da viagem (na volta).

\subsubsection{Gerúndio adjetivo}

Do gerúndio substituindo o particípio adjetivo registramo-lo apenas como predicativo em:

\footnotetext{
F1 I "Eu acho que a cultura aqui está muito relaxando."

$\mathrm{L}_{2} \quad$ "Eu acho que aqui a cultura está muito relaxada."
}

Nessa fala empregou-se relaxando (gerúndio) em lugar de relaxada (particípio), influência que atribuímos ao inglês relaxing, que pode corresponder a um particípio em português, como acontece com meaning ("significado") ou sitting ("sentado"). Recorreu-se, mais uma vez, ao -ndo do português por impossibilidade de correta atualização. Registra-se aqui a dificuldade em criar as formas de particípio em português. 
Podemos considerar, ainda nessa construção, uma eventual intenção de se dizer: "A cultura aqui está relaxando muito", uma estrutura que interfere na relação sintática intencional das palavras, especificamente na posição do advérbio muito.

\subsubsection{Gerúndio verbo}

Apresentamos agora casos de gerúndios decorrentes de inferências contextuais.

Analisaremos um caso comum do gerúndio, chamado de particípio presente em inglês, que corresponde literalmente a uma ação em andamento nas duas línguas. São situações especiais, em que o gerúndio não se acha expresso; no entanto, uma evidência subjacente o traz à tona, como constatam os textos das falas que serão apresentados:

\footnotetext{
F1 I "Depois do jantar, a família, a erma fica com televisão."

$L_{2} \quad$ "Depois do jantar, a família toda ficava assistindo à televisão."
}

$E m L_{2} \circ$ gerúndio assistindo (verbo+ -ndo), colocado em lugar da preposição com é uma inferência. A expressão ficar com, já tão recorrente e registrada, poderia ter sido substituída por ficar assistindo, uma forma bastante usual em inglês keep watching com transferência direta para o português.

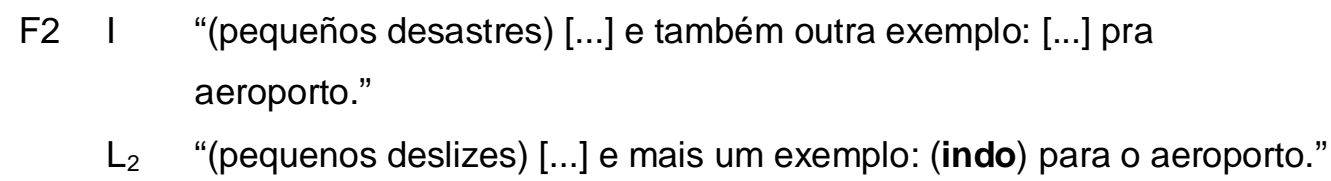

A lacuna observada leva também a uma inferência em $L_{2}$ : um verbo na forma de gerúndio, indo, que corresponde, como na fala anterior, a uma ação contínua (particípio presente em inglês, going). Apesar de ser um uso freqüente nos diálogos ingleses, não houve uma transferência direta, apoiada na relação entre as formas contínuas going (inglês) e indo (português). Optou-se, no caso, pela interrupção 
como já acontecera em outras ocasiões. Dá-se continuidade à fala com lacunas que comprometem a comunicação.

$$
\begin{aligned}
& \text { F3 I "[...] um sistema de governo muito complexo - junto com o nível } \\
& \text { federal, estadual, municipal." } \\
& \mathrm{L}_{2} \quad \text { "[...] um sistema de governo muito complexo unindo (que une) o nível } \\
& \\
& \text { (no âmbito) federal, estadual, municipal." }
\end{aligned}
$$

Nessa fala, em $L_{2}$, o gerúndio unindo está implícito na expressão junto com da interlíngua. Nota-se uma influência inadequada do inglês together with, uma transferência negativa, para compor em $L_{2}$ uma oração reduzida de gerúndio unindo, com valor adjetival em português, correspondente a uma oração adjetiva equivalente a que une, que compreende.

\subsubsection{Gerúndio: uso aleatório}

Observe-se a expressão realçada na fala:

$$
\begin{array}{lll}
\text { F1 I } & \text { "Nós fomos pra aeroporto sabendo nado conjunto." } \\
& \mathrm{L}_{2} \quad \text { "Nós fomos para o aeroporto, mas nenhum dos dois conhecia nada." }
\end{array}
$$

Verifica-se agora que o gerúndio, em sabendo nado, destoa em $L_{2}$ por falta de relação com os outros elementos da estrutura.

Para facilitar a decodificação da mensagem poderíamos sugerir como paráfrase de sabendo nado a expressão sem saber nada, em que fica bem nítida a correspondência do gerúndio com um infinitivo. A relação gerúndio/infinitivo vem nos salvar, mais uma vez, na busca de meios paralelos e funcionais para a compreensão da fala de nossos entrevistados. 


\subsubsection{Gerúndio: caso especial}

Exporemos neste item alguns mecanismos que envolvem as formas de gerúndio e infinitivo, registradas na seguinte fala:

F1 I Os homens de negócio estrangeiro passam muito tempo achando uma casa [...]"

$\mathrm{L}_{2} \quad$ "Os estrangeiros, homens de negócio, perdem muito tempo para achar uma casa."

Usou-se erroneamente o gerúndio achando para um verbo pontual, achar. As formas corretas em $\mathrm{L}_{2}$ seriam:

"[... ] muito tempo procurando (gerúndio)."

"[...] muito tempo para achar (infinitivo).

Essa é uma ocorrência bastante significativa para compreendermos as relações entre as formas de gerúndio e infinitivo, que precisariam, nesse caso, se adequar ao tipo de escolha lexical, evitando-se, assim, um problema morfossemântico.

Existem, aqui, duas possibilidades de uso. Se a opção for pelo verbo procurar que denota ação contínua, teremos o uso do gerúndio, procurando; se for pelo verbo achar, que denota ação pontual, teremos o uso do infinitivo, achar.

O desconhecimento das peculiaridades semânticas, diante de uma situação já reconhecidamente complicada para um falante da $L_{2}$ por se tratar da diferença entre achar e procurar, leva ao emprego mecânico da forma supostametne correta, produzindo-se a inadequação.

Como se verificou pelas falas analisadas neste capítulo, o gerúndio foi usado na $L_{2}$ tanto no lugar do infinitivo quanto no do particípio. Substituiu a classe dos substantivos e de adjetivos participiais além de ser usado aleatoriamente, causando muitas vezes dificuldades de compreensão das falas. 


\subsubsection{Infinitivo}

$\mathrm{Na}$ seqüência de nossa análise, apreciaremos o uso do infinitivo em seus diversos registros com os respectivos comentários, enquanto substantivo e suas respectivas funções, adjetivo e verbo em seus diferentes modos, tempos e flexões, sem desprezarmos seu emprego em casos especiais.

\subsubsection{Infinitivo substantivo}

O infinitivo é usado para preencher várias funções específicas da classe dos substantivos na $L_{2}$, tais como as de complemento verbal, nominal e de adjunto adnominal e ainda aparece em orações adverbiais.

\subsection{Complemento verbal}

No lugar de um complemento verbal em:

$\begin{array}{lll}\text { F1 } & \text { I } & \text { "Nós temos quatro }[. . .] \underline{\text { mudar estações. }} \\ & \mathrm{L}_{2} & \text { "Nós temos quatro mudanças (visíveis) de estação." }\end{array}$

o infinitivo mudar é usado indevidamente, substituindo o substantivo mudanças da $\mathrm{L}_{2}$, objeto direto do verbo ter completando-Ihe o sentido.

\subsection{Complemento nominal}

Atrelado a um nome, o infinitivo, em sintagmas preposicionados, substitui um substantivo simples para completar-Ihes o sentido como se observa nas: 
F1 I "Às vezes eu tenho saudades do $[\ldots]^{26}$ mudar os tempos."

$\mathrm{L}_{2} \quad$ "Às vezes eu tenho saudades da mudança de estações."

F2 I [...] essa é uma coisa social, não uma coisa que [...] de entender.

$\mathrm{L}_{2} \quad[\ldots]$ esse é um problema social e não uma questão de entendimento (compreensão).

e

F3 I "[...] o questión da falar contra govierno com música."

$\mathrm{L}_{2} \quad$ "[...] o problema da fala contra (da crítica) o governo através da música."

Nas falas 1 e 2, o entrevistado usou, respectivamente, do mudar e de entender e não da mudança e do entendimento, ignorando a regra de derivação sufixal.

$\mathrm{Na}$ fala 3, à semelhança do que se verificou em inúmeros contextos, o infinitivo falar substitui inadequadamente um substantivo, o deverbal fala, a ser recuperado pelo processo de derivação regressiva em $L_{2}$.

\subsection{Adjunto adnominal}

Como adjunto, verificamos o uso do infinitivo atrelado a nomes, substituindo substantivos em suas respectivas funções de adjunto adnominal

Observe-se agora o comportamento do infinitivo nas ocorrências:

F1 I "[...] o Conselho Britânico tem uma polícia do mudar as pessoas depois de 4 ou 5 anos."

$\mathrm{L}_{2} \quad$ "[...] o Conselho Britânico tem uma política de mudança das pessoas

\footnotetext{
${ }^{26}$ Usaram-se reticências na transcrição da fala 1 para representar a hesitação do falante quanto à seleção lexical.
} 
depois de 4 ou 5 anos (de permanência num país)."

e

F2 I "[...] e agora nós temos uma sistema de telefonar muito bom.

$\mathrm{L}_{2} \quad$ "[...] e agora nós temos um sistema de telefonia muito bom."

Em ambos os casos, uma polícia de mudar e uma sistema de telefonar, o infinitivo como modificador de nome, em sintagmas preposicionados atrelados respectivamente aos substantivos polícia (política) e sistema, preenche novamente a função de substantivos simples em $\mathrm{L}_{2}$, a saber, mudança e telefonia, em sintagmas devidamente formados por derivação sufixal.

\subsection{Adjunto adverbial}

Atrelado a verbo para indicar circunstâncias, o infinitivo é usado nas ocorrências:

F1 I "Eu não tinho bastante tempo aprender português."

$\mathrm{L}_{2} \quad$ "Eu não tinha tempo suficiente para a aprendizagem português."

ou "Eu não tinha tempo suficiente para aprender ."

Na primeira opção de correspondência, o infinitivo aprender assume o lugar e o valor de um substantivo simples representado pelo item lexical aprendizagem que resultaria da aplicação descartada da regra de derivação sufixal, numa função adverbial.

Em uma segunda opção de correspondência com a L2, estabelecendo uma relação de finalidade com o verbo ter da oração principal, o infinitivo aparece preposicionado, para aprender, o que não acontece com seu uso na interlíngua.

Em ambos os casos registra-se a passagem do infinitivo para a substantivação. 
F2 I "Eu tinha uma problema com compreensão."

$\mathrm{L}_{2} \quad$ "Eu tinha dificuldade para (de) compreender (para (de) entender)."

Encontramos nessa fala um procedimento inverso ao anteriomente observado: parte-se da substantivação para o infinitivo - um registro que evidencia uma reciprocidade de relações nominais entre substantivo e infinitivo. Consideramos mais usual em $L_{2}$, nesse caso, o uso do infinitivo em oração subordinada final, para (de) compreender, do que o emprego do substantivo compreensão, obtido pela nominalização do verbo compreender. Atribuímos tal seleção à semelhança fonética com a palavra inglesa comprehension. Acrescente-se a essa fala o uso inadequado da preposição com no lugar de de.

Passaremos a seguir a apreciar o uso do infinitivo na função específica de modificador adjetivo.

\subsubsection{Infinitivo adjetivo}

O infinitivo, neste caso, desempenha a função de adjunto adnominal, quer em substituição de um simples adjetivo quer na de locuções adjetivas.

Usado como um simples adjetivo encontramo-lo em:

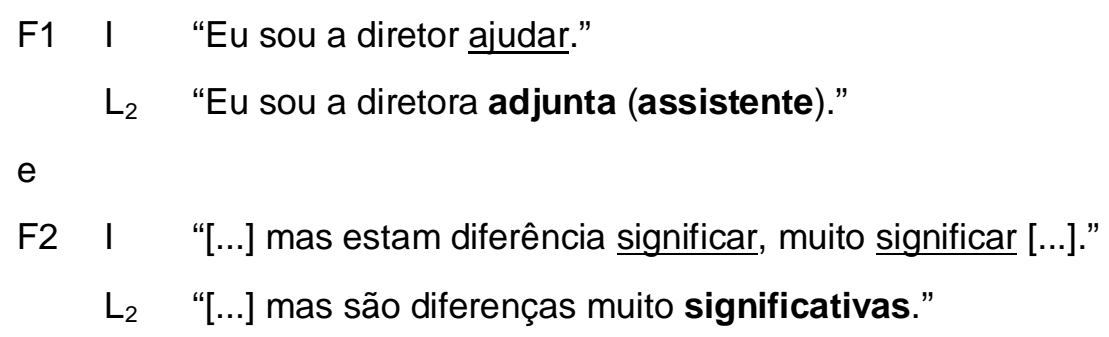

A seguir, no lugar de uma locução adjetiva de estudos em $\mathrm{L}_{2}$, o infinitivo preenche a função do deverbal preposicionado estudos na fala do entrevistado:

\footnotetext{
F1 I "Eu preciso uma bolsa estudar." $\mathrm{L}_{2} \quad$ "Eu preciso de uma bolsa de estudos."
} 
Supõe-se, pela ausência da preposição, que o entrevistado tenha encontrado no infinitivo uma forma de retratar a idéia de finalidade: bolsa para estudar, por incapacidade de estruturar adequadamente seu pensamento. A dicotomia bolsa para estudar (uma finalidade) e bolsa de estudos (uma caracterização) será objeto de atenção em outros casos a estes semelhantes.

Considere-se, agora, a fala:

\section{F1 I "Eu senti uma falta dos coisas de comida." \\ $\mathrm{L}_{2} \quad$ "Senti falta das coisas de comer."}

Nesse caso o falante não usou o infinitivo para formar a expressão de comer, perfeitamente adequada ao contexto, para substituir a função do adjunto adnominal comestíveis. Optou por uma alternativa que soou estranha e imprópria: um modificador composto pelo substantivo comida, que pelo fato de ser considerado uma nominalização do particípio, usada no feminino, permite supor na fala dos entrevistados, uma provável mistura das classes de palavras - nome e verbo, representadas pelas duas formas nominais envolvidas nas respectivas estruturas: de infinitivo (comer, verbo) e particípio (comida, nome).

Vejamos a seguir o infinitivo funcionando como verbo.

\subsubsection{Infinitivo verbo}

Usado em lugar de um verbo flexionado no modo finito tanto no modo indicativo quanto no subjuntivo, o infinitivo será analisado, considerando-se os níveis paradigmático e sintagmático.

\subsection{Modo indicativo: tempos simples}

Correspondendo ao modo indicativo tanto no tempo presente quanto no pretérito, em nível paradigmático, o infinitivo representa uma forma simples não só em períodos simples (orações absolutas) como em compostos. 


\subsection{Período simples (oração absoluta)}

Correspondendo ao modo indicativo presente, registram-se desses períodos as ocorrências:

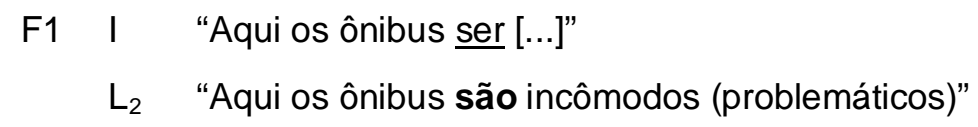

Nota-se aqui a falta de localização da palavra incômodos (problemática), a ser selecionada pelo falante, em sintonia semântica com o contexto que requer um adjetivo que caracterize o precário sistema de transporte. A ausência da palavra caracterizadora interrompe a frase que fica sem sentido.

Outras manifestações desse emprego estão presentes em:

$$
\begin{aligned}
& \text { F2 I “- a gramática é difícil - ter mais tipos de presente, futuro [...]" } \\
& \mathrm{L}_{2} \quad \text { "- a gramática é difícil - tem mais tipos de presente, futuro [...]" }
\end{aligned}
$$

e ainda para indicar um procedimento habitual em:

$$
\begin{aligned}
& \text { F3 I "Geralmente os funcionários do Conselho ficar em peís por até cinco } \\
& \text { horas." } \\
& \mathrm{L}_{2} \quad \text { "Geralmente os funcionários do Conselho ficam (permanecem) no } \\
& \quad \text { país até (por) cinco anos." }
\end{aligned}
$$

Correspondendo ao modo indicativo pretérito, registram-se desses períodos as ocorrências:
F1 I "Nós ficar com o apartamento deles."

$\mathrm{L}_{2} \quad$ "Nós ficamos no apartamento deles. "
e
F2 I "Eu ainda não ler todas as perguntas."
$\mathrm{L}_{2} \quad$ "Eu ainda não li todas as perguntas." 
Verificou-se nas duas falas, um uso inadequado do infinitivo, ignorando-se totalmente as flexões dos verbos ficar e ler.

\subsection{Período composto (oração coordenada e subordinada)}

Em se tratando de períodos compostos, o emprego do infinitivo pelo presente do indicativo registra-se tanto nos casos de coordenação quanto nos de subordinação.

\subsection{1 Coordenação}

Em orações coordenadas, observa-se o uso do infinitivo pelo presente do indicativo numa oração conclusiva relacionada à coordenada inicial pelo conectivo então em:

F1 I "[...] não existe um médio [...]; então o país do Brasil perder estes students de línguas."

$\mathrm{L}_{2} \quad$ “[...] não existe um meio [...]; então o Brasil perde (acaba perdendo) esses estudantes de língua.!"

\subsection{2 Subordinacão}

No período composto por subordinação o uso do infinitivo pelo indicativo presente eu viajar para o litoral se encontra na oração principal na fala:

F1 I "[...] quando eu tenha a oportunidade, eu viajar para o litoral."

$\mathrm{L}_{2} \quad$ "[...] quando eu tenho uma oportunidade, eu viajo para o litoral." 
$\mathrm{Na}$ fala seguinte o emprego do infinitivo pelo presente do indicativo se faz notar na oração subordinada temporal, quando o governo mudar :

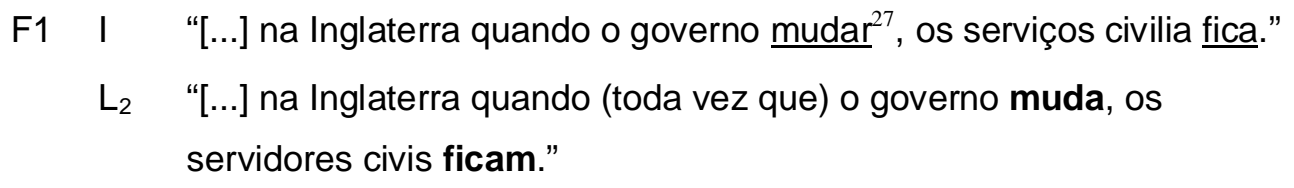

A própria natureza do texto, que trata de uma norma política, requer uma obediência à correlação temporal entre a oração principal e a subordinada, estabelecida nessas falas pelo presente do indicativo muda. O falante, no entanto, não soube conjugar o verbo da oração subordinada optando por mudar - a forma simples de infinitivo.

No emprego do infinitivo, como verbo no modo indicativo, conforme usado pelos entrevistados, as dificuldades não constituiram impedimento para a devida compreensão das falas.

\subsection{Tempos simples: caso especial}

Merece atenção o caso especial do emprego do infinitivo na manifestação do entrevistado sobre uma bagagem perdida:

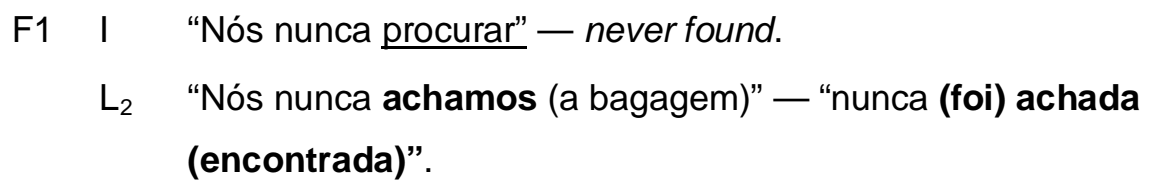

Além do uso do verbo procurar em vez de achar, já registrado e observado em 3.1.1.5, optou-se agora pelo infinitivo procurar, pela falta de localização da forma adequada para se referir ao tempo passado. Trata-se de um erro bastante comum entre os entrevistados, que possuem em sua língua poucas flexões verbais, e recorrem à forma básica do infinitivo.

\footnotetext{
${ }^{27} \mathrm{O}$ infinitivo mudar encontra-se na oração subordinada temporal.
} 
Podemos detectar, ainda, nessa fala, um outro fator referente à mistura e confusão do infinitivo procurar com o particípio achada. Ao usar indevidamente o tão reincidente infinitivo (procurar), o entrevistado reconhece sua opção errada, como se confirma em $L_{2}$, e sem conseguir localizar o particípio em português (achada), recorre ao inglês never found, na busca de uma correspondência que apresentasse a forma de past participle. Tentou buscar na expressão inglesa uma maneira de compensar sua falha.

É importante reconhecermos que houve um recurso ao emprego de uma expressão que pode ser justificada por uma tendência natural da língua inglesa, comumente encontrada nas narrativas, em se apoiar nas formas passivas - uso do past participle, particípio em português — para retratar fatos consumados.

\subsection{Modo indicativo: tempos compostos}

Em nível sintagmático o infinitivo aparece na forma composta em períodos simples e compostos como veremos a seguir.

\subsection{Período simples (oração absoluta)}

Desse uso registramos:

F1 I "Eu não saber contar o motorista do táxi meu endereço."

$\mathrm{L}_{2} \quad$ "Eu não soube dizer (informar) ao motorista do táxi o meu endereço."

Nessa fala constrói-se um sintagma formado por dois infinitivos saber e contar: o falante não conjugou o verbo regente, saber. Supomos ter havido não só um problema de contaminação fonética pela proximidade entre o verbo regente saber e o regido contar - influência do verbo regente no infinitivo ( mistake), como também a existência do extenso número de flexões verbais do português em contraposição à quase inexistência dessas flexões no inglês: o falante não 
conseguiu localizar a forma adequada recorrendo a uma não flexionada e cometendo uma falha de natureza morfológica (error).

\subsection{Período composto (oração subordinada)}

Verifica-se o uso do infinitivo, como verbo principal do sintagma em lugar do presente do subjuntivo apenas em período composto por subordinação: oração principal e subordinada, em:

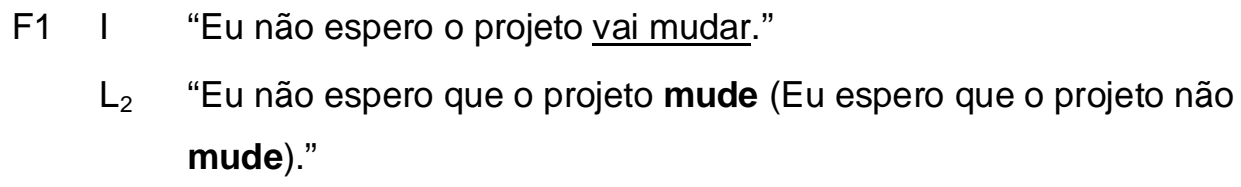

Esse sintagma formado pelo verbo ir+infinitivo, vai mudar, parece ter sido motivado pelo going to do inglês; encontra-se na oração subordinada, em lugar da forma adequada de subjuntivo. O uso do sintagma supre a função do subjuntivo, um modo verbal que parece estar ainda mais distante dos domínios dos falantes.

\subsubsection{Infinitivo: casos especiais}

Analisem-se as ocorrências:

F1 I "[...] o Conselho Britânico tem uma polícia do mudar as pessoas depois de 4 ou 5 anos."

$\mathrm{L}_{2} \quad$ "[...] $\mathrm{o}$ Conselho Britânico tem uma política de mudar as pessoas depois de 4 ou 5 anos.

e

F2 I "[...] o questión da falar contra govierno com música."

$\mathrm{L}_{2} \quad$ "[...] o problema de falar contra (criticar) o governo através da música." 
Essas falas apresentam uma dificuldade comum: uso desnecessário dos artigos definidos o e a (do e da) antes do infinitivo mudar e falar, nominalizando-o de maneira improcedente e estranha. Esse erro abalou a boa estruturação dos respectivos sintagmas, que requerem em $\mathrm{L}_{2}$ um infinitivo impessoal mudar e falar na forma básica - desprovido de determinantes como também de eventuais modificadores.

Criou-se assim, na primeira fala, uma confusão entre verbo e substantivo, respectivamente correspondentes às formas encontradas nas expressões de falar (um infinitivo) e da fala (um deverbal).

Observem -se agora as ocorrências:

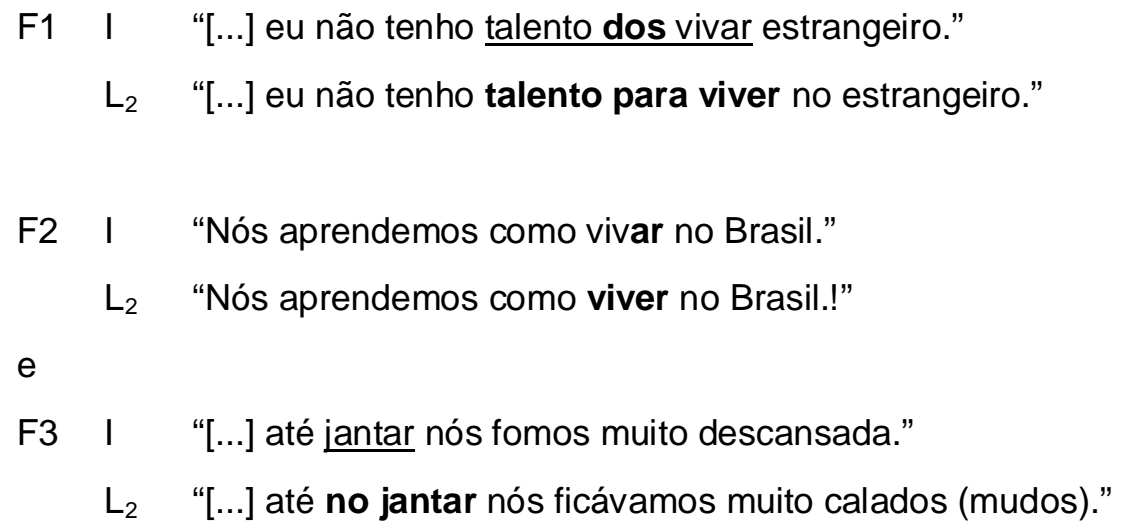

$\mathrm{Na}$ fala 1 encontramos um erro mais agravante: o artigo os (dos) que precede de maneira errônea o infinitivo vivar, desestruturando a expressão como nas anteriores e aparece ainda no plural. Além disso, ocorre na terminação -ar uma suprageneralização de $1^{\text {a }}$ conjugação: usou-se a forma vivar em lugar de viver", verbo da $2^{\mathrm{a}}$ conjugação.

Esse sintagma talento dos vivar, permite uma inferência que merece atenção: a presença do infinitivo acreditamos eventualmente insinuar uma escolha intencional do falante, que procurou, através dessa forma nominal, transmitir uma idéia de finalidade, só que para conseguir uma adequação estrutural, deveria fazer uso da preposição para e não da de, como vemos no texto. É importante observar que a preposição de poderia permanecer no sintagma, mas para isso teríamos de substituir o núcleo talento pela palavra condições, assim a expressão para viver, com idéia de finalidade, passaria a de viver, que assumiria uma função diferente: a de completar o significado do nome condições. 
$\mathrm{Na}$ fala 2 usou-se adequadamente 0 infinitivo, mas repetiu-se a suprageneralização de primeira conjugação usando a terminação -ar em um verbo de segunda conjugação (viver), caracterizada pela terminção -er

Já na fala 3 encontra-se uma situação inversa aos dois primeiros casos apresentados; não se fez a nominalização, afetando de maneira perceptível a compreensão da fala; a ausência do artigo o gerou uma mistura de verbo e nome, criando ambigüidade entre até o jantar ("até chegar o jantar" ) e até no jantar ("durante o jantar" ).

A partir da análise das falas apresentadas, consideramos que o infinitivo assume uma função eclética.

O uso abusivo dessa forma pelos falantes, por não saberem a forma verbal adequada gera uma prática atualização recursiva em total desacordo com as normas gramaticais oficialmente estabelecidas em $\mathrm{L}_{2}$.

Os entrevistados, condicionados a uma quase inexistência de flexões verbais em inglês, vêem-se diante de uma imensidão de variedades de formas verbais um universo de flexões em português - encontradas no modo finito. Incapazes de conjugar os verbos da $L_{2}$ recorrem a alternativas para suprirem suas dificuldades: exploraram quase que inconsciente e automaticamente o infinitivo na sua forma não flexionada, acarretando, sérias irregularidades na estruturação da fala. Afora as dificuldades próprias das diferenças entre as duas línguas, aliam-se problemas devidos a ineficiências pedagógicas que acreditamos devam ser sanadas com base em resultado de pesquisas confiáveis a respeito do ensino-aprendizagem da língua portuguesa para estrangeiros.

É raro o uso correto das flexões verbais e das derivações sufixais de substantivos e de adjetivos. Adota-se o infinitivo na sua forma não flexionada para uma função eclética conforme dito: desempenhar o papel das diversas classes de palavras.

A dificuldade na formação de palavras (verbo, substantivo e adjetivo) configura-se devido à opção constante pelo infinitivo - uma prática, que conseqüentemente passa a representar uma das maiores provas dos problemas relacionados com a morfologia. 
3.1.2.5 Infinitivo: problemática flexional

Tendo em vista o fato de o infinitivo poder ou não ocorrer de forma flexionada, refletiremos sobre seu uso na forma impessoal e na pessoal. Assim sendo, os registros seguintes com seus respectivos comentários serão apresentados respeitando-se essa distinção, respectivamente, nos casos A e B.

\subsection{Caso A: infinitivo impessoal}

Exibiremos aqui as falas que confirmam o uso alternativo do infinitivo diretamente associado à incompreensão do uso e flexão dos tempos verbais. No entanto, ele é trocado por várias formas verbais em situações que exigem sua presença.

F1 I "É uma aula de português para ajuda o trabalho".

$\mathrm{L}_{2} \quad$ "São aulas de português para ajudar no trabalho."

F2 I " "...] as pessoas que têm um talento das línguas não está as pessoas melhores ensaia língua".

$L_{2} \quad$ "[...] as pessoas que têm facilidade para línguas não são as mais indicadas para ensinar uma língua."

F3 I "O entusiasmo dos brasileiros conhece outros países".

$\mathrm{L}_{2} \quad$ "O entusiasmo dos brasileiros em conhecer outros países."

e

F4 I "[...] talvez aprenda a História do Brasil é muito interessante".

$L_{2} \quad$ "[...] talvez seja muito interessante aprender História do Brasil."

As formas do modo finito ajuda, ensaia, conhece, no presente do indicativo e aprenda, no presente do subjuntivo, destoa em lugar reservado ao infinitivo impessoal. 
Analisando essas quatro ocorrências, nota-se o emprego inadequado das formas verbais que não o infinitivo, usadas mecanicamente, gerando agramaticalidade.

Considerando as falas, observamos o seguinte: o entrevistado para evitar um possível erro através do uso alternativo do infinitivo provoca a impropriedade pelo caminho inverso, pois, como vimos, nos três primeiros casos, usa-se erroneamente o presente do indicativo, ajuda, ensaia e conhece. Nas duas falas iniciais ajuda e ensaia aparece em lugar do infinitivo ajudar e ensaiar ("treinar") para indicar finalidade, que no primeiro caso ficaria assegurada pela marca da preposição para (para ajudar); no segundo caso, no entanto, observa-se um agravante: a ausência da respectiva preposição para dificulta ainda mais a inferência da intenção da falante. No terceiro caso, o presente do indicativo, conhece, foi usado em lugar do infinitivo conhecer, que deveria aparecer precedido da preposição em para exercer a função de complemento nominal do núcleo entusiasmo. No quarto caso selecionase, de maneira errada, a forma aprenda do presente do subjuntivo, que ficou em lugar do correto infinitivo aprender para exercer a função de sujeito, isto, provavelmente, pela influência do advérbio talvez.

Os falantes exteriorizam certa ansiedade com a possibilidade de incorrer no mesmo erro ao escolherem, durante a elaboração de suas falas, a forma impessoal - não flexionada - do infinitivo, por não terem assimilado adequadamente os mecanismos de flexão verbal no tempo e pessoa correta, como já ocorrera em várias situações constrangedoras ao cometerem uma falha que comprometia significativamente a boa expressão em português.

Os entrevistados, por falta de domínio da forma verbal procedente, utilizam uma forma alternativa que, embora evidencie desencontros de empregos não chegam a comprometer significativamente a decodificação da mensagem do texto. Tais ocorrências serão demonstradas nos casos que passaremos a apreciar.

Nas falas anteriormente comentadas e em outras ocorrências semelhantes empregam-se os verbos no modo finito (presente do indicativo nos três primeiros casos; presente do subjuntivo no quarto caso), uma maneira de flexionar supostamente apropriada para os falantes, mas inadequada de acordo com as normas oficiais da língua portuguesa, pois esses contextos requerem infinitivo. Ocorreu então o mesmo nível de agramaticalidade dos casos contrários em que a ausência do infinitivo, não mais a sua presença, é o que causa impropriedade e 
improcedência no uso, gerando o erro. Conseqüentemente, comete-se um erro comum com iniciativas opostas: quer por não se flexionar o verbo em algumas situações quer por flexioná-lo em outras. $\mathrm{Na}$ verdade, as formas apropriadas, exigidas por dois contextos diferentes, não são percebidas.

\subsection{Caso B: infinitivo pessoal}

Quanto ao emprego do infinitivo pessoal, observem-se as ocorrências 1 e 2:
F1 I "[...] até agora não existe um médio a coisas internacionais para eles trabalham e usam esta língua.

Equivalente às seguintes correspondências em $\mathrm{L}_{2}$ :
F1 $L_{2} \quad$ a) "[... ] até agora não existe um meio para eles trabalharem e usarem essa língua com assuntos (atividades) internacionais."
ou b) "[...] até agora não existe um meio para que eles trabalhem e usem essa língua com assuntos internacionais."

Em (a) apresentamos uma opção de infinitivo pessoal (forma flexionada do infinitivo) não usada pelos falantes provavelmente por se tratar de um tipo de flexão menos rotineira e ainda não convenientemente assimilada, que exigiria a concordância em número com o referente eles - trata-se de um problema encontrado até no falante-nativo da língua portuguesa no Brasil. Os verbos aparecem, então, como alternativa na forma de presente do indicativo, para eles trabalham e usam, um uso impróprio por não expressarem a idéia de finalidade claramente subentendida na expressão, que alcançou total adequação na forma de infinitivo em $\mathrm{L}_{2}$.

Em (b) apresentamos uma situação diferente: utilizamos uma paráfrase com um tipo de construção desdobrada, para que eles ttrabalhem e usem, também aceitável, através do uso do subjuntivo, indicando possibilidade ou eventualidade, 
mas, por ser uma forma de difícil assimilação, aparece com pouca freqüência nas falas elencadas.

Focalizemos agora segunda fala e sua respectiva correspondência:

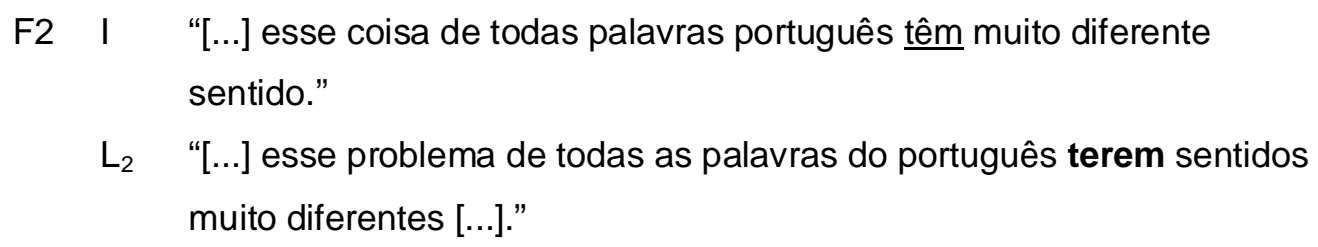

A opção pelo infinitivo pessoal em $\mathrm{L}_{2}$, uma flexão possivelmente inacessível aos falantes, como já observamos, vem corrigir o uso inadequado e improcedente do presente do indicativo na interlíngua, que aparece na oração: esse coisa de todas palavras português têm muito diferentes sentido [...], onde a expressão: de todas palavras português [...], exerce a função de um complemento nominal da palavra coisa, como podemos comprovar pela presença da preposição de. O deslocamento dos componentes da oração - inversão de sujeito e verbo na $\mathrm{L}_{2}$ : essa coisa de terem todas as palavras do português sentidos muito diferentes. deixa mais evidente a necessidade do uso do infinitivo flexionado no plural, concordando em número com o núcleo do sujeito palavras.

Essa ocorrência mostra um caso mais problemático do infinitivo pessoal, pois envolve transformações do texto para a compreensão de uma estrutura subjacente, como demonstraremos adiante.

Conforme observamos, o infinitivo pessoal, a forma flexionada do infinitivo, revelou-se uma das maiores dificuldades para a assimilação das disponibilidades morfológicas encontradas no universo de flexões da língua portuguesa. Esse fato, no entanto, apesar de incomodar os estudiosos da língua, não dificultou a decodificação da mensagem.

Trataremos a seguir dos problemas relativos à combinação das formas verbais, - os chamados sintagmas verbais. 


\subsubsection{Sintagmas verbais}

Os sintagmas verbais, ora entendidos como uma seqüência de verbos regentes e regidos estão representados por uma grande variedade de padrões encontrados em nosso corpus de análise. Serão apreciados em estruturas compostas por dois ou por mais de dois componentes, em agrupamentos e individualmente, ou apresentados em forma de quadro de correspondências, seguindo as características morfossintático-semânticas de cada um com os respectivos comentários, conforme segue.

\subsubsection{Sintagmas com dois componentes}

Observem-se as falas do primeiro grupo:

F1 I "Nós preferimos tem contratos, papel"

$\mathrm{L}_{2} \quad$ "Nós (do Conselho) preferimos ter contratos por escrito."

F2 I "Eu tento falo, mas não conseguio."

$L_{2} \quad$ "Eu tento falar, mas não consigo."

F3 I "[...] realmente eu gosto fala português, mas [...]"

$L_{2} \quad$ "[...] realmente eu gosto de falar português, mas [...]"

F4 I "[...] agora eu posso entendo as notícias."

$L_{2} \quad$ "[...] agora eu posso entender as notícias do rádio."

e

F5 I "Eu não saber contar o motorista do táxi meu endereço."

$\mathrm{L}_{2} \quad$ "Eu não soube dizer (informar) ao motorista do táxi o meu endereço."

Nos casos 1, 2, 3 e 4, os verbos regentes flexionados, respectivamente preferimos, tento, gosto e posso, deveriam ser seguidos por um verbo no infinitivo. 
No entanto, o falante conjugou erroneamente os dois verbos tanto o regente como o regido no presente do indicativo, preferimos tem, tento falo, gosto fala e posso entendo, influenciados talvez, em 2, tento falo e 4, posso entendo, pela terminação dos verbos regentes, num processo de contaminação.

No caso 3, gosto fala, nota-se a má estruturação do sintagma, causada pelo desrespeito à regência do verbo gostar que requer a presença da preposição de. Atribuímos, ainda, a agramaticalidade desse sintagma ao fato de as mesmas formas poderem representar classes gramaticais diferentes: fala (verbo) e fala (nominalização do verbo, um deverbal), o que admitiria a expressão gosto da fala, em que a palavra fala, precedida do determinante $a$, passa a assumir a função (o valor) de um nome (substantivo).

No caso 5, eu não saber contar, além da inadequação semântica encontrada no verbo regido contar em vez de dizer - uma dificuldade bastante freqüente nas falas analisadas, não se conjugou o verbo regente, possivelmente por desconhecimento da conjugação ou eventualmente por contaminação morfológica e até mesmo fonética do sufixo -er do verbo vizinho (próximo) a ele agregado. Conseqüentemente, os dois verbos permaneceram no infinitivo, saber contar.

Observou-se, nesse primeiro grupo de sintagmas, uma contaminação morfológica justificada pela influência do verbo regente sobre o verbo regido

No segundo grupo temos:

F1 I "Eu gostaria ter um trabalho no Brasil."

$\mathrm{L}_{2} \quad$ "Eu gostaria de fazer um trabalho no Brasil."

F2 I "Eu precisei ter uma autoridade [...]"

L2 "Eu precisava manter minha autoridade (me impor) [...]"

F3 I "Eu preciso de explicar para vocês [...]"

$\mathrm{L}_{2} \quad$ "Eu preciso explicar para vocês [...]"

e

F4 I "[...] então eu falei inglês porque eu precisei ter uma posição do chefe."

$L_{2} \quad$ "[...] eu falava, então inglês porque eu precisava assumir uma postura de chefe." 
No caso 1, desrespeita-se a regência do verbo gostar pela omissão da preposição de; usa-se gostaria ter.

As falas 2 e 3 exibem uma instabilidade na construção do sintagma verbal devido ao acerto da regência do verbo precisar na fala 2, precisei ter, e o erro do mesmo falante na fala 3 , evidenciado pela presença desnecessária da preposição de em preciso de explicar.

A fala 4, conforme o contexto, destina-se a exprimir ações habituais no passado, mas torna-se descaracterizada pelo uso de tempos verbais incompatíveis. Entretanto, o sintagma verbal precisei ter se apresenta bem estruturado, pois optouse corretamente pelo verbo regente, o modal precisar, que denota essa obrigatoriedade. Contudo, não se alcançou a adequação no emprego do tempo verbal: usou-se o pretérito perfeito do indicativo em lugar do imperfeito, uma forma requerida também na oração principal para o estabelecimento de uma correlação de hábitos. Apesar de o sintagma verbal ter sido bem estruturado quanto à escolha do verbo precisar, cabe ressaltar a escolha semântica imprópria do verbo principal: houve opção por ter, como verbo vicário, em vez de o mais indicado assumir.

Conforme verificado os verbos gostar e precisar assumem, nessas falas, a função de verbo regente.

No terceiro grupo, teceremos comentários a respeito da expressão ir+infinitivo, tendo em vista a estruturação dos sintagmas.

Analisem-se as falas:

F1 I "Eu vou viver em São Paulo até três anos"

$\mathrm{L}_{2} \quad$ "Eu vou ficar (morar) em São Paulo por três anos."

F2 I "Eu estou nervioso você vai usar por uma outra assunto."

$\mathrm{L}_{2} \quad$ "Eu estou preocupada porque você pode usar (esta entrevista) para uma outra finalidade."

ou "Eu estou achando ${ }^{28}$ que você vai usar para uma outra [...]."

28 Esse sintagma já traz subentendida a idéia de preocupação e pode admitir, então, a permanência de "vai usar". 
F3 I "[...] porque você gostaria aprender inglês, você vai ficar lá uns seis meses.!"

$L_{2} \quad$ "[...] se você gostaria de aprender (quer aprender) inglês, você deveria (deve) ficar lá (na Inglaterra) uns seis meses."

F4 I "Eu não espero o projeto vai mudar."

$\mathrm{L}_{2} \quad$ "Eu não espero que o projeto mude."

ou "(Eu espero que o projeto não mude.)"

F5 I "Se eu vou ir pra outra país, agora eu vou desenvolver uma sistema muito bom."

$\mathrm{L}_{2} \quad$ "Se eu for para outro país, agora (depois de toda essa experiência) eu vou (sei, saberei) desenvolver (criar) uma técnica muito boa."

F6 I "[...] hoje nós vamos falar com o vocabulário do aeroporto."

$\mathrm{L}_{2} \quad$ "[...] hoje nós vamos usar (trabalhar ( quero aprender) o vocabulário do aeroporto."

Em 1, registra-se vou viver, forma de expressão que atribuímos à influência do inglês going to; sendo, nesse caso, mais apropriada a alternativa sugerida em $\mathrm{L}_{3}$, vou ficar ("morar").

Em 2, apesar de a correspondência do sintagma verbal em $\mathrm{L}_{2}$, pode usar, ficar mais adequada para explicitar a idéia de eventualidade pretendida, a escolha vai usar, presente na oração subordinada, não destoa, por se encontrar em um contexto em que a expressão da oração principal introdutória Eu estou nervioso já transmite essa intenção.

Em 3, além da falha na regência do verbo gostar, gostaria aprender, na oração subordinada, o sintagma verbal em $\mathrm{L}_{2}$ com o verbo modal deveria/deve correspondente a vai ficar presente na interlíngua, expressa de forma mais adequada a idéia de conselho, ("sugestão") subentendida no contexto.

Em 4, usou-se o sintagma vai mudar por influência do inglês going to até para o modo subjuntivo em $L_{2}$, na oração subordinada do período espero que o projeto mude. Escolhe-se uma forma que transmite uma idéia real em vez da hipotética mude/venha mudar. 
Em 5, queremos crer que também se encontra uma possível influência do inglês going to go. Usaram-se formas inadequadas à construção de orações condicionais. Criou-se uma mistura entre os modos da oração principal e os da subordinada: o indicativo vou aparece, erroneamente na subordinada em lugar do subjuntivo se eu for.

Em 6, além da escolha semanticamente imprópria do verbo regido falar, o sintagma vamos falar com não corresponde à intenção do falante, inferida pelo contexto, uma tomada de decisão, o que se obtém pela expressão quero aprender.

Da observação do uso do verbo ir+inf, conclui-se que os entrevistados, de acordo com o contexto, estruturam o sintagma verbal de maneira inadequada, devido à combinação imprópria do verbo ir como verbo regente seguido pelo infinitivo, uma forma estigmatizada para a função de futuro imediato.

Considere-se agora a fala:

$$
\begin{array}{cl}
\mathrm{F} 1 \quad \mathrm{I} & \text { "Eu acho que agora eu deve dar os aulas pra você [...]" } \\
\mathrm{L}_{2} & \text { "Eu julgo que agora eu (já) posso, consigo (possa, consiga) dar } \\
& \text { aulas para você [...]" }
\end{array}
$$

No sintagma deve dar verifica-se uma escolha inadequada de verbo regente dever para exteriorizar a idéia de capacidade, condições que, de acordo com o contexto, estaria devidamente representada pelos verbos poder, conseguir. A forma deve registrada nessa fala apresenta ainda mais dois tipos de erros: quanto à pessoa do verbo, deve em vez de devo, e quanto ao modo verbal, deve em vez de deva.

As formas verbais posso, consigo no modo indicativo, sugeridas em $\mathrm{L}_{2}$, correspondentes ao que se observa em deve na interlíngua, também nesse mesmo modo, não ocasionariam problema de acordo com a norma usual. O subjuntivo, no entanto, representa de maneira mais expressiva a idéia de probabilidade face à intencionalidade do falante.

Se compararmos essa fala com a fala 3 do grupo anterior, percebemos que 0 verbo dever sugerido na fala $3 \mathrm{em} \mathrm{L}_{2}$, substitui a inadequação semântica do emprego do verbo ir da interlíngua. Entretanto, na fala em análise, o verbo dever, presente em eu deve dar, corresponde a "poder", "conseguir" o que demonstra que 
o mesmo verbo solicitado em um contexto 1 é rejeitado em outro, ocasionando um problema de seleção lexical para o falante.

Na fala:

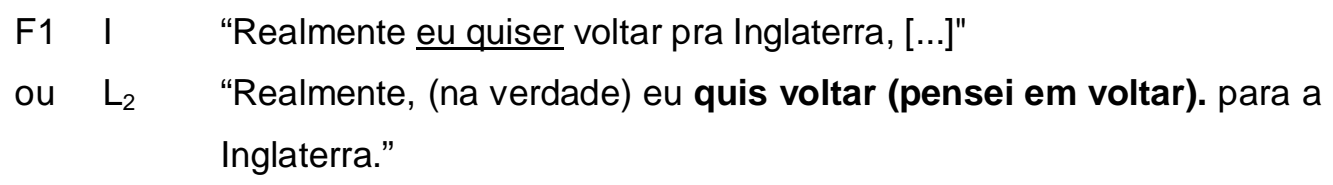

Nota-se agora uma dificuldade na conjugação do verbo. Usou-se equivocadamente o futuro do subjuntivo quiser, que sugere uma certa aproximação morfológica com o infinitivo querer, mais especificamente por apresentarem o mesmo tipo de sufixo, já que é muito freqüente o registro de sintagmas verbais inadequados, a exemplo da composição aceitável de dois infinitivos: querer voltar. Não se deve descartar também a possibilidade de a opção improcedente pela forma do subjuntivo ter acontecido conscientemente, considerando o fato de ela muitas vezes coincidir, na língua portuguesa, com a forma do infinitivo. Essa confusão no uso do verbo gerou um erro em eu quiser voltar, que encontra correspondência correta em eu quis voltar, conforme $\mathrm{L}_{2}$.

Observou-se aqui um caso específico: sintagma mal estruturado em que o verbo regente no modo subjuntivo, quiser, substituiu o indicativo, quis, tornando-se necessária a inferência para que se pudesse compreender a mensagem.

Atente-se a seguir para as falas:

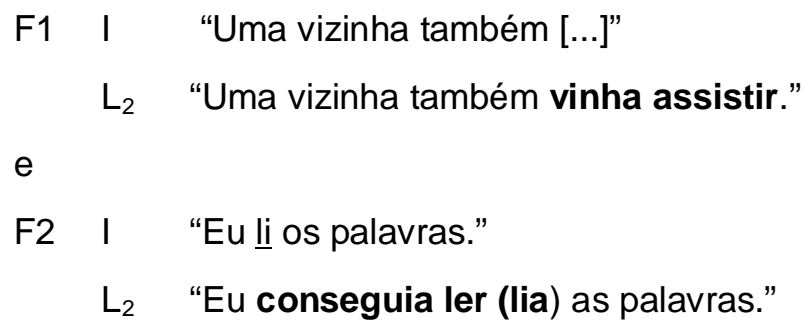

A exemplo do que ocorreu anteriormente, subentende-se, na fala 1, pela presença de também a informação inferida pelo contexto, tendo em vista as referências precedentes. Essa informação foi veiculada em $L_{2}$ pelo sintagma vinha 
assistir, que o falante não construiu apesar de esta possibilitar uma transferência direta do inglês, came to watch.

Em 2, não se criou também um sintagma que transmitisse a idéia de capacidade, ("condições") como se observa em $\mathrm{L}_{2}$ : empregou-se, iinclusive, o pretérito perfeito do indicativo do verbo ler, (li) em lugar do imperfeito lia, descaracterizando a idéia de freqüência de ação no passado, implícita no contexto.

Quanto aos sintagmas verbais com dois componentes, verificamos que as construções desrespeitaram as formas apropriadas de tempo, modo, número, pessoa e aspecto verbal, incluindo a indevida combinação lexical, decorrente muitas vezes da influência da língua inglesa como demonstraremos a seguir.

\subsection{Sintagmas de dois componentes: influências do inglês}

$\mathrm{Na}$ seqüência da análise dos sintagmas verbais compostos por dois elementos, reservamos este espaço para as prováveis influências da língua inglesa, refletidas nas estruturas subseqüentes.

Sobre a incidência da construção ir + infinitivo considerem-se:

F1 I "Eu vou viver em São Paulo até três anos."

$\mathrm{L}_{2} \quad$ "Eu vou ficar, ficarei (vou morar, morarei) em São Paulo por três anos."

F2 I "Eu estou falando com pessoa, com certeza, não vai estar lá durante 99."

$\mathrm{L}_{2} \quad$ "Eu estou falando com uma pessoa que, com certeza não estará lá em 99."

F3 I "Quatro ou cinco anos eu acho que eu vou ficar aqui."

$\mathrm{L}_{2} \quad$ "Eu acho que ficarei aqui por quatro ou cinco anos."

F4 I "[...] hoje nós vamos falar com o vocabulário do aeroporto."

$L_{2} \quad$ "[...] hoje nós vamos usar, usaremos (trabalharemos com) 0 vocabulário do aeroporto." 
F5 I "Eu acho que eu vou voltar para a Inglaterra, outro país, mas não é [...]"

$\mathrm{L}_{2} \quad$ a) "Eu voltarei para a Inglaterra ou para outro país, mas não é nada certo."

ou de acordo com o contexto, infere-se pela obrigatoriedade do retorno

ou "Eu devo voltar para a Inglaterra ou para outro país, mas não é nada certo."

F6 I "Eu estou nervioso você vai usar por uma outra assunto."

$L_{2} \quad$ a) "Eu estou preocupada porque usará (esta entrevista) para uma outra finalidade."

ou "Eu estou preocupada porque você pode usar (esta entrevista) para uma outra finalidade."

F7 I "[...] porque você gostaria aprender inglês, você vai ficar lá uns seis meses."

$\mathrm{L}_{2} \quad$ "[...] se você gostasse ("quisesse") inglês, você deveria ficar lá (na Inglaterra) uns seis meses."

F8 I "Eu não espero o projeto vai mudar."

$\mathrm{L}_{2} \quad$ "Eu não espero que o projeto possa mudar."

F9 I "Se eu vou ir pra outra país, agora eu vou desenvolver uma sistema [...]"

$L_{2} \quad$ "Se eu for para outro país, agora eu sei (saberei) criar uma técnica [...]"

Encontramos nas nove falas transcritas a rotineira influência do going to do inglês, já observado anteriormente, transferido literalmente para o português, como vou ver, vai estar, vou ficar, vamos falar, vou voltar e vai usar, numa emissão quase padronizada das formas correspondentes ao futuro em português. Trata-se da incidência do ir+infinitivo na expressão dos falantes da língua inglesa, portanto, um reflexo bem perceptível dessa influência.

Observamos, ainda, que os sintagmas compostos por verbos modais, como, poder, dever presentes em $\mathrm{L}_{2}$, são bastante expressivos semanticamente por imprimirem às respectivas noções de possibilidade e de obrigatoriedade correspondentes à intenção do falante, como se pode inferir pelo contexto nas falas 
de números: 5 , vou voltar por devo voltar, 6 , vai usar por pode usar; 7 , vai ficar por deveria ficar e 8, vai mudar por possa mudar.

Esses casos demonstram uma dificuldade na assimilação e domínio dos verbos modais bastante presentes e semanticamente necessários aos diálogos.

Devemos destacar ainda as ocorrências em que se trunca a informação da mensagem, devido à hesitação do falante na construção do sintagma verbal, uma insegurança representada pelas reticências, como ocorre em:

\section{F1 I "[...] e também ele quis [...] en [...] ensaio gramática." \\ $\mathrm{L}_{2} \quad$ "[...] e também ele quis treinar gramática."}

Percebe-se nessa fala, uma dificuldade de estruturação do sintagma: conjugaram-se os dois verbos da construção, causando estranheza e agramaticalidade à expressão, que requer o verbo regido na forma de infinitivo, ensaiar ("treinar"). Podemos, ainda, inferir nessa estrutura um outro tipo de problema, gerado por uma confusão de classes, pois usou-se em lugar do infinitivo o deverbal ensaio, um substantivo, visivelmente reconhecido pelo fato de o verbo regente querer estar no pretérito perfeito e na $3^{\underline{a}}$ pessoa do singular.

Apreciem-se, agora:

F1 I "Esto uma história muito interessante porque eu fiquei aqui seis meses mais ou menos."

$\mathrm{L}_{2} \quad$ "Esta é uma história muito complicada porque eu fiquei/tive de ficar (resolvendo esse problema) 6 meses mais ou menos."

e

F2 I "Depois do jantar, a família, a erma fica com televisão, com a novela das oito."

$\mathrm{L}_{2} \quad$ "Depois do jantar, a família toda e a irmã ficavam assistindo à televisão, à novela das oito."

Em 1, a correspondência com o sintagma: fiquei resolvendo (esse problema) foi inferida pelo contexto.

Em 2, apesar de essa estrutura com gerúndio, ficar assistindo, em $\mathrm{L}_{2}$ corresponder diretamente à do inglês, keep watching, permitindo uma transferência 
positiva para o português, isto não se verifica nessa construção. Além disso, no sintagma ocorre ainda o uso da preposição com gerando a expressão ficar com, que acabou, por seu uso aleatório, destoando dentro do referido contexto.

As ausências de formas lexicais necessárias à estruturação dos sintagmas verbais pertinentes à fala dos entrevistados confirmam a falta de acesso dos falantes a tais construções. É um fato atrelado ao nível de exigência na composição dessas expressões, apesar de elas apresentarem, muitas vezes, uma relação com a língua inglesa, como o caso das mencionadas estruturas correspondentes a ir + gerúndio na $L_{2}$.

\subsubsection{Sintagmas com três componentes}

Quanto ao uso de sintagmas de três componentes registramos:
F1 I "[,,,] a menos que queira falar perguntando."
$\mathrm{L}_{2} \quad$ "[...] a menos que queira continuar perguntando."
F2 I "Eu prefero de ficar voando."
$\mathrm{L}_{2} \quad$ "Prefiro ficar voando."
F3 I "(Isso) pode ser para atrapalhar muito." $\mathrm{L}_{2} \quad$ "(E isso) serve para atrapalhar (acaba atrapalhando ${ }^{29}$ ) muito."

Em 1, cria-se um sintagma correto do ponto de vista gramatical, queira falar perguntando pelo fato de ele apresentar uma relação sintática bem esmerada. No entanto, nota-se uma falha na escolha lexical do segundo componente da expressão, pois usou-se o verbo falar, seguido do perguntar, gerando uma certa redundância.

\footnotetext{
${ }^{29}$ um sintagma verbal - se encaixaria muito bem.
} 
Em 2, apesar do erro de regência verbal encontrado na presença da preposição de em prefero de ficar, construiu-se muito bem o sintagma.

Em 3, registra-se em português uma expressão artificial, pode ser para atrapalhar muito, que foi de certo modo transferida do inglês, create an obstacle. $O$ contexto nos revela claramente a intenção do falante, exteriorizada de forma objetiva na correspondência em $\mathrm{L}_{2}$, serve para atrapalhar ou acaba atrapalhando.

Cabe considerar que se compararmos as expressões: pode ser para atrapalhar e acaba atrapalhando, vemos que a segunda é mais sintética, mais própria e objetiva - acrescenta mais espontaneidade à manifestação do falante.

Examinando as dificuldades expostas nesse elenco de sintagmas, verificamos que algumas expressões não aparecem nas falas analisadas apesar de serem requisitadas e funcionais para uma comunicação eficiente na $L_{2}$, como é o caso de ficar+gerúndio e de acabar+gerúndio. Trata-se de um recurso que consideramos não assimilado ocasionando tentativas de "ensaio e erro" nas situações de comunicação dos falantes da $L_{2}$, que necessitam de uma aprendizagem mais efetiva para 0 domínio da língua, considerando-se que os referidos sintagmas estão diretamente condicionados ao uso e possíveis transferências do versátil -ing para suas funções de gerúndio (-ndo) e infinitivo em português (-r).

O sintagma acabar+gerúndio aparece subentendido em outras ocorrências que comprovam sua funcionalidade na busca de formas mais naturais de expressão.

Observem-se a falas:

F1 I "Não existe um médio para eles trabalham e usam esta língua; então o país do Brasil perder estes estudantes de línguas."

$\mathrm{L}_{2} \quad$ "Não existe um meio de eles trabalharem e usarem essa língua; então o Brasil perde (acaba perdendo esses estudantes)."

Tem-se nessa fala mais um caso evidente da necessidade de se reconhecer a pertinência do sintagma acabar + gerúndio, que se acha subjacente ao infinitivo perder, escolhido como um recurso de comunicação, dada a incapacidade de se flexionar adequadamente os verbos, de acordo com o modo e tempo convenientes, ou por não se achar uma outra forma de expressão substitutiva desse infinitivo.

Ainda com relação à pertinência da expressão veja-se: 
F2 I "[...] mas eu acho que eu aprende português da rua com os lojas, [...].

$\mathrm{L}_{2} \quad$ "Infelizmente eu acho que (no fim) eu aprendi (acabei aprendendo.

Consegui aprender) português coloquial com os lojistas, etc. [...]."

Além da improcedência na opção pela conjunção mas, colocada em lugar do advérbio infelizmente, há uma remota possibilidade de o falante, pelo tipo de construção criada (presente do indicativo, tempo simples), não ter conseguido localizar uma forma de expressão mais apropriada ao contexto, que representasse melhor seu pensamento e que coincide com o que se propõe o referido sintagma. As interpretações sugeridas entre parênteses, em $L_{2}$, bastante afastadas do que podemos observar na fala do entrevistado, demonstram o que deixa transparecer uma inadequação metodológica de ensino de português para estrangeiros.

Esses dois casos merecem atenção, pois os referidos sintagmas verbais em $\mathrm{L}_{2}$, correspondem a uma paráfrase bem adequada ao contexto, acaba perdendo e acabei aprendendo por se tratar de uma forma de expressão usual e bem própria da língua portuguesa, que vem dar ao diálogo um cunho mais autêntico. No entanto, com base nas falas elencadas, sua pertinência não é percebida.

Consideramos, então, que expressões do tipo ficar, acabar+gerúndio, eventualmente não memorizadas por falhas nas técnicas de condicionamento e retenção, deveriam fazer parte do syllabus estabelecido no programa de português para estrangeiros, já que reconhecidas pela sua funcionalidade em situações de comunicação.

Formas não usuais ou importadas do inglês, expressões e combinações que geram manifestações confusas e apelativas do pensamento, denunciam um inventário ainda precário que requer reestruturação.

Outro caso bastante significativo encontra-se na expressão eu estou nervioso na fala:

F3 I "Eu estou nervioso você vai usar por uma outra assunto".

A expressão eu estou nervioso que significa em português "eu estou preocupada", pode ser parafraseada, ainda, como já observamos anteriormente, da seguinte maneira: 
F3 $L_{2} \quad$ "Eu estou achando que você vai usar [ ...]"

O sintagma introdutório eu estou achando, seria a expressão apropriada, coloquial e freqüente nos diálogos, para demonstrar a insinuada preocupação pela contextualização da fala em $\mathrm{L}_{2}$.

Todas essas dificuldades, confirmando insuficiência nas práticas e aplicações metodológicas do ensino de português para estrangeiros, seriam resolvidas com base em pesquisas e uma elaboração cuidadosa do material a ser adotado, que exigiria o acompanhamento paralelo de um treinamento mais apropriado a diferentes situações.

Nossa investigação deixa transparecer que o conhecimento e domínio de algumas expressões específicas e prioritárias pela sua freqüência e utilização prática são pré-requisitos significativos na seleção e organização do material lingüístico.

Acreditamos ser ainda pertinente acrescentar duas falas em que o uso da preposição com estabelecer uma relação entre essa preposição e as formas nominais de gerúndio e particípio, gerando interferências que, apesar de não afetarem diretamente a comunicação, não são aceitas pelos defensores da gramaticalidade lingüística:

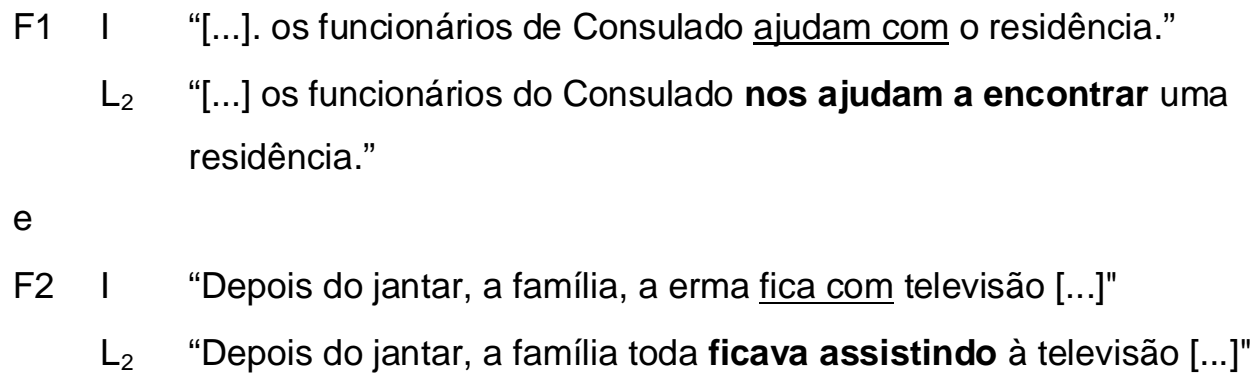

Esses casos apresentam uma estrutura que envolve indiretamente as formas nominais de infinitivo e gerúndio pelo fato de estarem eles implícitos no uso da preposição com. No primeiro caso empregou-se a preposição com em lugar do verbo regido encontrar - um infinitivo - que completaria o sintagma ajudam a encontrar. No segundo, a preposição com foi inadequadamente usada na função de uma outra forma nominal: o gerúndio assistindo. Em resumo, a presença da preposição com na fala dos entrevistados apresenta duas vertentes: remete a dois 
significados diferentes transmitidos pelas respectivas formas nominais, que, apesar de implícitas, assumem um papel preponderante na interpretação do texto. Além disso, o uso inadequado dessa preposição faz parte das alternativas adotadas para que sejam supridas as dificuldades encontradas nos atos de fala dos entrevistados.

Enfim, o uso improcedente da referida preposição acabou gerando expressões que, apesar de impróprias, mereceram destaque pela sua pertinência em nosso trabalho, que se propõe a levantar as dificuldades reveladas pelos falantes da $L_{2}$, sobretudo aquelas que contrariam a gramaticalidade do texto, comprometendo a comunicação.

Da análise dos sintagmas verbais, evidenciou-se a dificuldade dos falantes quanto à estruturação desses sintagmas. Além das inadequações semânticas observadas (deve dar por possa, consiga dar), ocorre a flexão de todos os componentes do sintagma (preferimos tem), introduzem elos desnecessários desvirtuando a regência de verbo auxiliar (preciso de estudar), não constroem o tempo composto no sintagma verbal mudando o aspecto do verbo regente (li por conseguia ler, pontual por freqüentativo), usam ir+gerúndio de forma viciosa (vou ir), omitem o sintagma interrompendo a fala (uma vizinha também [...]), usam a preposição com para substituir as formas nominais do verbo (ficar com televisão por ficar assistindo à televisão), contaminação fonética (posso entendo), ausência do elo que relaciona os elementos do sintagma (gosto falar), não localização de sintagmas formados por ficar e/ou acabar+gerúdio responsáveis pela intencionalidade da fala (aprende português por acabei aprendendo). Portanto, os erros decorrem tanto pelas inadequações lexicais quanto pelas omissões de elementos necessários e ainda pelo acréscimo aleatório de outros, prejudicando a comunicação.

Passamos a seguir à observação dos sintagmas formados por nomes, substantivos ou adjetivos

\subsubsection{Sintagmas nominais e sintagmas adjetivais}

Nesta etapa de nosso trabalho, concentrar-nos-emos inicialmente nas falhas e inadequações registradas na estruturação dos sintagmas nominais e dos 
sintagmas adjetivais, assunto a ser apresentado, respectivamente nesses dois grupos, como segue.

\subsubsection{Sintagmas nominais}

Neste grupo em que o núcleo nominal do sintagma corresponde a um substantivo adotaremos uma subdivisão das expressões de acordo com seus respectivos elos e modificadores.

\subsection{Elos}

Analisemos os elos, observando os registros:

F1 I "Este coisa de Ensino Inglês no Brasil."

$\mathrm{L}_{2} \quad$ "O problema do Ensino de Inglês no Brasil."

F2 I "[...] esse coisa de todas as palavras português têm [...]"

$\mathrm{L}_{2} \quad$ "...] esse fato de todas as palavras do português terem [...]

F3 I "[...] mas esso coisas o mundo inteiro."

$\mathrm{L}_{2} \quad$ "[...] mas isso são coisas do mundo inteiro."

e

F4 I "Ele gosta do sol, o ambiente, o litoral [...]"

$\mathrm{L}_{2} \quad$ "Ele gosta do sol, do ambiente, do litoral [...]"

Nas falas transcritas verificaram-se problemas relacionados com emprego da preposição de.

Trata-se de casos que se caracterizam pela ausência da preposição de (o) ou da substituição desta pelo artigo definido o: ensino inglês, palavras português, coisas o mundo inteiro.

Essa ausência dos devidos elos de ligação em 1, ensino inglês, e 2, palavras português, denotam uma confusão quanto ao emprego do modificador, representado 
por adjetivo ou locução adjetiva. Usaram-se os substantivos inglês e português inadivertidamente na função de adjetivos pátrios, perdendo-se as respectivas relações de matéria (disciplina) estabelecidas pela preposição de.

$\mathrm{Na}$ substituição da preposição de pelo artigo o em 3, coisas o mundo inteiro perdeu-se a relação de posse entre o núcleo coisas e o modificador mundo inteiro

$\mathrm{Na}$ fala 4, em gosta o litoral, além da omissão da preposição de exigida pela regência do verbo gostar, nota-se ainda a repetição excessiva do elo de (o), numa única estrutura, uma seqüência admissível, porém a omissão da preposição em 0 litoral desestruturou o sintagma.

Na seqüência dos registros temos:

$$
\begin{array}{cll}
F 1 \quad \text { I } & \text { "Cine Sesc tem uma seleção dos filmes das Artes." } \\
& L_{2} \quad \text { "O Cine Sesc tem uma seleção de filmes de Arte." }
\end{array}
$$

onde se considera desnecessária a contração da preposição de com o artigo definido as, em filmes das artes:

Ressalta-se que, no caso, não há ausências de elos, pois eles foram estabelecidos com a preposição correta, mas especificaram os substantivos filmes e Artes, sem necessidade, por meio do uso do artigo.

Quanto aos elementos relacionais (elos), atente-se ainda para:

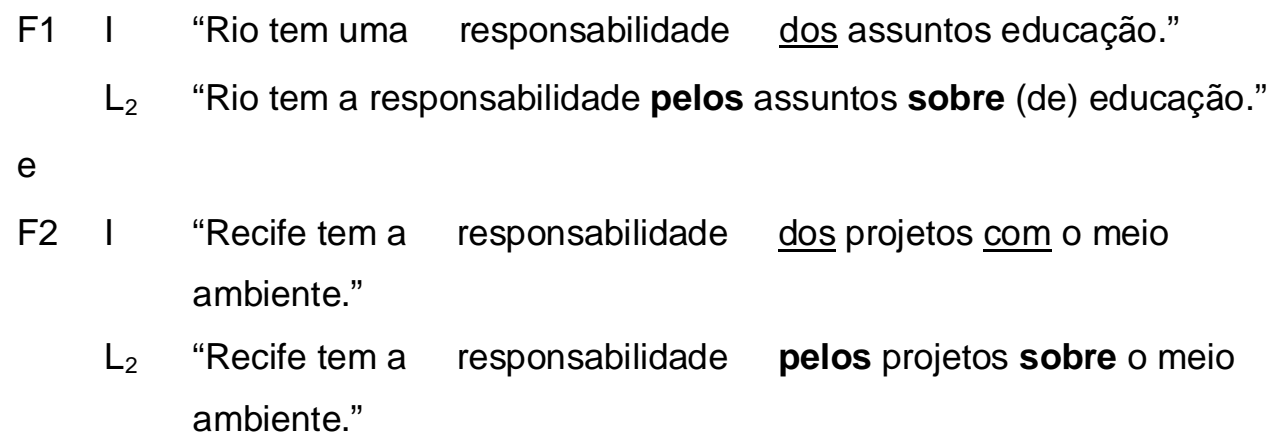
ambiente."

$\mathrm{L}_{2} \quad$ "Recife tem a responsabilidade pelos projetos sobre o meio ambiente."

F3 I "Brasília tem a responsabilidade do todos os mundo diplomático."

$\mathrm{L}_{2} \quad$ "Brasília tem a responsabilidade por todo o mundo diplomático."

e

F4 I "Eu tinha a responsabilidade dos país do América Latina."

$\mathrm{L}_{2} \quad$ "Eu tinha a responsabilidade pelos países da América Latina." 
Os complementos do núcleo responsabilidade encontrados nesses sintagmas nominais revelam, além do uso abusivo da preposição de, a pouca familiaridade em $\mathrm{L}_{2}$ com as preposições por, pelo (per+artigo o) em 1, 2, 3 e 4, e sobre em 1 e 2, significando respectivamente "através de" "a respeito de", e merecendo destaque o uso de sobre em 2, inadequadamente substituída por com na interlíngua.

Essas opções envolvendo o uso incorreto da preposição de em lugar de pelo e sobre num conjunto de estruturas sintagmáticas idênticas, evidenciam o uso incontrolado dessa preposição que se confunde com outras formas e deixa de assumir, em lugar das preposições mais apropriadas, as atribuições semânticas exigidas pelo contexto.

Essa mesma dificuldade aparece, também, em mais um registro semelhante:

$$
\begin{aligned}
& \text { F1 I "Eu tinho a responsabilidade por o desenvolvimento das aulas." } \\
& \mathrm{L}_{2} \quad \text { "Eu tinha a responsabilidade pelo desenvolvimento das aulas.", }
\end{aligned}
$$

onde o elo por 0 , foi escolhido, mas não se verifica, no caso, a assimilação da forma pelo, fato que atribuímos à inexistência desse tipo de contração em inglês. A preposição e artigo separados causam aqui um efeito fonético bastante artificial.

Já na fala:

F1 I "[...] eu aprende português com os motoristas do táxi, os meninos no escritório [...]"

$\mathrm{L}_{2} \quad$ "[...] eu aprendi português com os motoristas de táxi, (com) os meninos do escritório [...],"

não se observa a distinção entre o uso das preposições de e em responsáveis respectivamente por uma complementação de idéias, os motoristas do táxi, e uma localização, os meninos no escritório.

Também não se preservou o caráter genérico da expressão com os motoristas do táxi: usou-se o artigo o, contraído com preposição de, o que acabou especificando sem necessidade a idéia do núcleo do sintagma, os motoristas.

Em os meninos no escritório, especificou-se corretamente a idéia, mas criouse uma contração do artigo o com a preposição em e não com a de, como acontece 
em português, escolha essa que atribuímos à influência direta do inglês boys in the office, perdendo-se, assim, certa expressividade.

Considere, agora, a ocorrência:

F1 I “ “...] têm muitos transtornos do trânsito.

O sintagma transtornos do trânsito, usado pelo falante, poderia ser substituído por:

Transtornos de trânsito

(adjunto adnominal)

(ausência do artigo) ou Transtornos no trânsito ( adjunto adverbial ) (combinação prep+artigo)

Apesar de os elementos de ligação, de e no, entre núcleo e modificador serem diferentes em $L_{2}$, não gerando uma mesma função sintática, são cabíveis as duas opções apresentadas para a fala do entrevistado, na medida em que a nuance que distingue os dois usos não altera significativamente o sentido da mensagem peculiaridade que não verificamos em outros pares de preposição, como no caso do de e do para, que geraram significados distintos para as respectivas funções.

No que se refere à distinção entre o uso de de e de para, respectivamente complementação de idéias e sentido de finalidade, veja-se:

$\begin{array}{lll}F 1 & \text { I } & \text { "[...] obter permissão de dirigir, de pilotar." } \\ & L_{2} & \text { "[...] obter permissão para dirigir, para pilotar." }\end{array}$

A preposição para, sugerida em $\mathrm{L}_{2}$, aproxima-se mais da intenção do falante: denotar finalidade, objetivo.

Consideramos aqui que essa escolha indevida no emprego da preposição de pelo falante descaracterizou semanticamente a intenção do falante pela função errônea atribuída a ela, como vemos na correspondência em $L_{2}$.

Em relação à ocorrência:

F1 I "[...] aproveitar os parques como Ibirapuera [...]. esse coisas de crianças.", 
cabe lembrar que em essas coisas de crianças e essas coisas para crianças constituem uma particularidade da língua portuguesa, como se esclarece:

- coisas de crianças são "coisas próprias de (normais em) crianças"

e

- coisas para crianças são "coisas tendo como objetivo as crianças", "cuja finalidade são as crianças".

Essa dificuldade do falante gera problema semântico, pois altera significativamente o sentido das expressões.

Na fala:

F1 I "[...] eu não tenho um talento bem da língua."

$\mathrm{L}_{2} \quad$ "[...] eu não tenho muita habilidade (facilidade) para a (aprendizagem da) língua."

a preposição de+art a inibe a idéia de finalidade inferida através do sintagma um talento bem da língua.

Nesse caso, a inadequação do elo da ao contexto ao introduzir um modificador, descaracteriza semanticamente a estruturação dos sintagmas.

Analisemos agora a ocorrência:

F1 I "O Distrito Federal dificulta nosso trabalho o coisas da alfândega."

$\mathrm{L}_{2}$ "O Distrito Federal dificulta nosso trabalho com os servicos da alfândega."

Registra-se nessa fala a omissão de com, elo apropriado à composição do sintagma, descaracterizando a relação semântica estabelecida pela presença da preposição.

Caso semelhante também ocorre em:

F1 I "Você tem litoral muito lindo, o Amazonas, o mundo natural."

$\mathrm{L}_{2}$ "Vocês têm (o Brasil tem) um litoral muito lindo, o Amazonas com todo seu ambiente natural." 
A omissão da preposição com ocasiona, nessa fala, a desarticulação da construção o Amazonas, o mundo natural. Recupera-se esse problema pelo uso do referido instrumento gramatical com, introduzindo o sintagma preposicionado, modificador de o Amazonas, obtendo-se o Amazonas com todo seu ambiente natural, que inclui ainda a substituição do item lexical mundo por ambiente.

Cabe registrar ainda as ocorrências:

$\begin{array}{lll}\text { F1 I } & \text { "O problema é na aula de alunos." } \\ & \mathrm{L}_{2} \quad \text { "O problema está na aula com os alunos".. }\end{array}$

Nessa manifestação sobre a dificuldade dos alunos durante as aulas, registrase o uso inadequado da preposição de em lugar da preposição com alterando-se totalmente o significado do texto.

E na

F1 I "Aqui uma pessoa com táxi não tem nada (conhecimento nenhum).",

$\mathrm{L}_{2} \quad$ "Aqui no Brasil, um motorista de taxi não sabe nada

nota-se o uso inadequado da preposição com em vez de de.

Encontra-se aqui o inverso da situação anterior: a escolha imprópria da preposição com em lugar da preposição de. Criou-se a expressão: pessoa com táxi, uma forma bem distante da usual, para se referir ao motorista de táxi.

Acrescente-se às dificuldades relacionadas à fala:

F1 I "Eu não tinho bastante tempo aprender português."

$\mathrm{L}_{2} \quad$ "Eu não tinha bastante tempo para aprender português."

Constrói-se um sintagma incompleto tempo aprender pela ausência do elo para, precedendo o infinitivo - uma preposição que vem cumprir com sua função básica de indicar finalidade.

Além das dificuldades relativas ao uso das preposições, convém destacar o uso da partícula que no lugar da preposição sobre, para ou até mesmo de, em: 
$\begin{array}{lll}\mathrm{F} 1 & \mathrm{I} & \text { "[...] tem um curso que viagem }[\ldots] " \\ & \mathrm{~L}_{2} & \text { "há um curso sobre viagem (para viagens ou de viagem)" }\end{array}$

Atribui-se essa troca que por de ao uso inaceitável da partícula que em construções como ter que fazer substituindo a preposição de.

Consideramos também falhas relevantes as que constam das ocorrências:

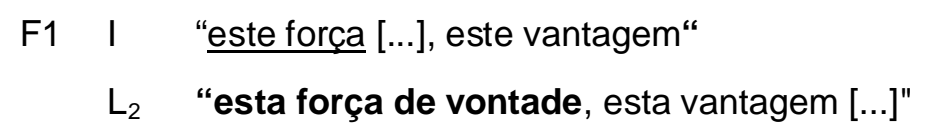

Sem o complemento de vontade, a palavra força adquire um sentido vago; a interrupção e lacuna entre núcleo e complemento provocam uma desestruturação da frase a ser atribuída à dificuldade em localizar-se o elo de, adequado à expressão.

F2 I "[...] o comercial de estrangeiros assuntos roubos."

$L_{2} \quad$ "[...] o comercial de estrangeiros sobre assuntos de roubos."

Esse sintagma composto por um núcleo comercial, o comercial de estrangeiros sobre assuntos de roubos corresponde a um adjunto adnominal e a um complemento nominal, dispostos respectivamente na seqüência de uma estrutura que pode ser assim resumida: [...] o comercial de estrangeiros sobre roubos. A desestruturação do sintagma de deve à omissão dos relacionadores preposicionais adequados

Um caso particular verifica-se em:

F1 I "Esse problema de todas as palavras do português terem sentidos diferentes",

pois o texto possui uma flexibilidade estrutural que possibilita dois tipos de paráfrases:

F1 $\quad L_{2} \quad$ "Esse problema dos diferentes sentidos de todas as palavras do português."

ou "Esse problema de todas as palavras do português com (terem) sentidos diferentes." 
$\mathrm{Na}$ segunda opção em $\mathrm{L}_{2}$, a paráfrase acabou revelando uma coincidência bastante significativa para o enriquecimento de nossos mecanismos de avaliação e reestruturação dos sintagmas: um contexto em que o elo (de ligação) com se confunde com o modificador terem (na forma de infinitivo pessoal). Um estudo mais minucioso sobre esse caso será apresentado adiante, na abordagem sobre "modificadores nominais" - no item relativo ao uso do infinitivo pessoal.

Como se verificou, o uso dos elos na construção dos sintagmas nominais representa uma das dificuldades detectadas por meio da análise das falas dos entrevistados, incapazes de trabalhar com os mecanismos necessários a uma aceitável estruturação desses sintagmas, no sentido de estabelecer as relações sintático-semânticas apropriadas ao contexto..

Tais dificuldades se evidenciam tanto pela omissão das preposições, quanto por questões relativas a problemas das contrações de preposições com artigos. Acrescentem-se ainda o uso indevido desses instrumentos gramaticais bem como seu emprego incontrolado ocasionando construções inaceitáveis do ponto de vista da norma oficial da língua portuguesa.

A escolha e criação inadequada de elos desrespeitam as respectivas referências e dependências de seus elementos, adulterando suas relações sintáticas. Conseqüentemente, as informações são transmitidas numa linguagem que não só deixa de cumprir com a sua função precípua de representar, de maneira correta a intenção do falante, como também gera ambigüidades.

Além disso, a maneira anômala e estranha na criação e uso de alguns componentes em nível morfossintático-semântico, ou separadamente, colaboram ainda para bloquear a emissão espontânea e aceitável dos pensamentos, tornandoos incompreensíveis.

Nossa atenção, a seguir, volta-se para os modificadores do nome .

\subsection{Modificadores}

Nesta parte do trabalho faremos uma apresentação das falhas encontradas nos modificadores dos núcleos dos sintagmas nominais. 
Daremos em primeiro lugar um enfoque aos casos relacionados às formas nominais de gerúndio, infinitivo e particípio, que serão avaliadas pelas respectivas presenças e ausências em contextos selecionados.

\subsection{Gerúndio, infinitivo e particípio}

\subsection{1 Gerúndio}

Considere-se a presença do gerúndio em:

F1 I "[...] agora eu deve dar os aulas pra você porque meu experiência aprendendo português."

$\mathrm{L}_{2} \quad$ "[...] agora eu posso dar aulas para você pela minha experiência em aprender português."

Verifica-se um sintagma nominal mal estruturado: experiência aprendendo, subst+gerúndio, uma transferência automática, resultante de um recurso ao -ndo em português enquanto correspondência direta do -ing do inglês, pelo fato de essa relação ser admissível com bastante freqüência em muitos outros contextos.

\subsection{2 Infinitivo}

Observe-se a presença do infinitivo impessoal em:

F1 I "Agora nós temos uma sistema de telefonar muito bom."

$\mathrm{L}_{2} \quad$ "Agora nós temos um sistema de telefonia (telefônico) muito bom."

e

F2 I "Às vezes eu tenho saudades do [...] mudar os tempos"

$\mathrm{L}_{2}$ "Às vezes eu tenho saudades da mudança das estações" 
Usou-se, respectivamente em 1 e 2, o infinitivo preposicionado de telefonar e de mudar, erroneamente como modificador de sistema e de saudades.

Há casos em que se verifica a presença correta do infinitivo, apesar de ele aparecer com a terminação incorreta, normalmente de primeira conjugação como em talento dos vivar, em que vivar ocorre caracterizando uma suprageneralização morfológica. A má estruturação desse sintagma gerou problemas em seus três componentes: no núcleo, no elo e no modificador. São os tipos específicos de erros encontrados em cada componente, que comentaremos a seguir.

Veja-se a fala:

F1 I "Eu não tenho talento dos vivar estrangeiro." $\mathrm{L}_{2} \quad$ "Eu não tenho capacidade (estrutura) para viver no estrangeiro.

Para comentar as falhas, destacaremos os componentes do sintagma

Talento

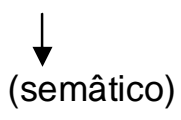

dos

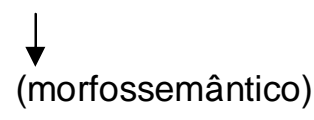

vivar

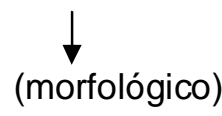

Observa-se em $\mathrm{L}_{2}$ que o núcleo talento apresenta um problema de inadequação semântica; o elo, preposição de aparece com dois tipos de erros: um morfológico, pois se acha contraído com o artigo masculino e ainda no plural, os, e outro semântico pelo seu uso impróprio, em lugar da preposição para, denotando finalidade, conforme já comentado. Quanto ao terceiro componente do sintagma, vivar, o erro está no uso da terminação -ar no lugar de -er, para um verbo de $2^{\underline{a}}$ conjugação, viver.

Considere, agora a ausência do infinitivo na fala:
F1 I "O entusiasmo dos brasileiros conhece outros países."
$\mathrm{L}_{2} \quad$ "O entusiasmo dos brasileiros em conhecer outros países (inf. impessoal)."

Se desmembrarmos esse texto, teremos: 


\section{"O entusiasmo dos brasileiros" \\ "O entusiasmo em conhecer"}

Encontramos um núcleo entusiasmo e dois modificadores correspondentes em $L_{2}$ a: dos brasileiros e em conhecer. Usou-se incorretamente na fala o presente do indicativo conhece em lugar do infinitivo impessoal conhecer, para compor o segundo modificador em conhecer - um complemento nominal.

Na fala:

$$
\begin{aligned}
& \text { F1 I "[...] esse coisa de todas palavras português têm muito diferente } \\
& \text { sentido." } \\
& \mathrm{L}_{2} \quad \text { "[...] esse problema de todas as palavras do português terem sentidos } \\
& \text { muito diferentes (inf. pessoal) }
\end{aligned}
$$

observamos que o sintagma todas as palavras do português funciona ao mesmo tempo como modificador do núcleo problema e como núcleo virtual do restante da fala, já que aparece como sujeito de uma oração com o verbo ter (todas as palavras do português têm sentidos diferentes), que permite uma paráfrase: todas as palavras do português com sentidos diferentes, na qual o referido sintagma assume também a função de núcleo.

Se considerarmos a subjacência dessa fala, teríamos correspondência com as paráfrases em diferentes níveis, conforme:

1 -"Todas as palavras do português têm um problema."

1a -"Esse problema de todas as palavras do português."

2 -"Todas as palavras do português têm sentidos diferentes."

$2 a$-"Os sentidos diferentes de todas as palavras do português."

ou ainda:

2b -"Todas as palavras do português com (têm) sentidos diferentes."

Se juntarmos essas estruturas ainda em nível intermediário teríamos:

-"Esse problema de todas as palavras do português."

-"Todas as palavras do português têm sentidos diferentes." 
Portanto, ao chegarmos ao nível superficial da linguagem reunimos essas estruturas em uma versão reduzida através da eliminação dos componentes idênticos e de uma transformação do verbo ter, do indicativo para o infinitivo pessoal, obtendo:

"Esse problema de todas as palavras do português terem sentidos diferentes."

A evolução do raciocínio apresentado nesses diferentes níveis estruturais vem elucidar a presença latente na composição original da referida ocorrência de dois núcleos: o problema e todas as palavras do português, como já observamos e dois modificadores, um inserido no outro ou um único modificador ampliado: de todas as palavras do português com diferentes sentidos, que podem ser facilmente identificados pelas referências e elos de ligação: de e com existentes entre eles.

Na fala:

$\begin{array}{lll}\text { F1 } & \text { I } & \text { "Eu tinha problema com compreensão." } \\ & \mathrm{L}_{2} \quad \text { "Eu tinha dificuldade para (de) compreender (entender)." }\end{array}$

Apesar de o substantivo compreensão ser usado de uma forma aceitável, nota-se que nessa estrutura, o infinitivo conhecer vem implícito através desse substantivo, como demonstra claramente a paráfrase da $L_{2}$, o que confere a existência de uma relação nominal entre esse substantivo e o infinitivo.

\subsection{3 Particípio}

O problema, relacionado ao particípio, a ser focalizado, corresponde a uma falha caracterizada pela ausência dessa forma nominal na fala, que pela sua pertinência ao contexto teria facilitado a compreensão das idéias transmitidas.

Veja-se: 
F1 I "Eu tenho a responsabilidade das Artes do Conselho no Brasil."

$\mathrm{L}_{2} \quad$ "Eu tenho a responsabilidade sobre Artes (eventos, atividades artísticas) organizadas pelo Conselho no Brasil."

Quanto ao uso do particípio observamos que são raros os registros dessa forma nominal nas falas investigadas, apesar da correspondência quase direta nas duas línguas: inglês e português.

\subsection{Criações morfossintático-lexicais improcedentes}

Observe-se a estrutura sintagmática nas duas ocorrências transcritas abaixo. Na primeira, o falante ao se referir ao trânsito no Brasil, assim se manifestou:

$\begin{array}{lll}\text { F1 } & \text { I } & \text { "[...] você não tem no sistema do transportiva público, mas [...]." } \\ & L_{2} & \text { "[...] vocês não têm no sistema de transportes públicos, mas [...]. }\end{array}$

e na segunda ao se posicionar quanto ao festival de cinema, disse:

F1 I "São Paulo tem o festa dos filmes jurídica muito interessante."

$\mathrm{L}_{2} \quad$ "São Paulo tem o festival, muito interessante, para julgamento (crítica) de filmes.

ou "São Paulo tem o festival de filmes para crítica deles."

Verifica-se na primeira fala a presença de um "falso adjetivo" transportiva resultante de uma derivação do substantivo transporte, em desacordo com as normas gramaticais em vigor, portanto, uma criação sem respaldo morfológico em português. Na segunda, emprega-se o adjetivo jurídica, uma classe de palavras apresentando função destoante e improcedente: vem substituir para julgamento, um complemento nominal de festival de filmes, o qual não equivale a um adjetivo, mas a um sintagma preposicionado que tem um nome (festival) como núcleo. 


\subsection{Seqüência ilógica e insuficiência nos componentes referenciais}

Observe-se a fala:

F1 I " "[...] gostaria falar [...] eu não tinha o pessoa do telefone [...]."

$L_{2} \quad$ "[...] gostaria de falar [...] eu não tinha $o$ telefone da pessoa [...]."

ocorre falha na seqüência dos componentes do sintagma, causando alteração nas funções lógicas a eles atribuídas. Esse procedimento acarreta, muitas vezes, uma troca de referências pela inversão de núcleo e modificador e gera interpretações incompatíveis com a intenção do falante. $\mathrm{Na}$ fala apreciada, a inversão gerou um raciocínio contrário ao esperado. Num paralelo com a $L_{2}$ temos:

- a pessoa do telefone significando "a pessoa de um determinado telefone" (referente: pessoa) e

- o telefone da pessoa significando "o telefone de uma determinada pessoa" (referente: telefone)

Criou-se, nesse caso, um problema sintático semântico pela troca de referência, resultando uma seqüência ilógica: eu não tinha o pessoa do telefone.

Nas expressões:

um dos líderes dos país.

e

um dos países líderes

a inversão da ordem dos termos do sintagma: o caracterizador, lideres, pela coisa caracterizada, um dos países, confirma a dificuldade na estruturação do sintagma nominal que nesse caso, gerou uma interpretação totalmente distorcida em relação à que se desejava comunicar: um dos países líderes.

Na construção:

"um estrutura tópica por um tópico estrutural, 
à semelhança do que ocorreu no caso anterior, usou-se o substantivo estrutura no lugar de tópico, uma inversão de núcleo e modificador e conseqüente troca de classes gramaticais, conforme correspondência com $\mathrm{L}_{2}$.

Nas falas:

$$
\begin{array}{lll}
\text { F1 } & \mathrm{I} & \text { "a economia e a corrente, a moeda de [...] do Brasil" } \\
& \mathrm{L}_{2} & \text { "a economia e a moeda corrente do Brasil" } \\
\text { e } & & \\
\text { F2 } & \mathrm{I} & \text { "[...] que eu tenho a direito a acesso às coisas }[. . .] " \\
& \mathrm{~L}_{2} & \text { " }[\ldots] \text { que eu tenha direito de acesso às coisas }[. . .] "
\end{array}
$$

Nota-se a desestruturação sintática por falha na combinação entre núcleo e modificador do sintagma. Na primeira delas, substantivou-se, corrente um adjetivo mencionando-o imediatamente antes do substantivo ao qual se refere e separando-o deste, como dois elementos distintos. Identifica-se confusão na formação de uma expressão já conhecida, registrada e rotulada moeda corrente [substantivo+adjetivo]. $\mathrm{Na}$ segunda, a má estruturação do sintagma a direito a acesso às coisas demonstra uma confusão entre o uso do artigo a e da preposição de, acarretando uma alteração na função do componente a acesso, presente na interlíngua, o qual, além de núcleo nominal, assume também a função de modificador do nome direito na $L_{2}$.

No registro seguinte:

$$
\begin{aligned}
& \text { F1 I "Gosto bem farino do temporada com milhas você tem no coisas de } \\
& \text { comida." } \\
& \mathrm{L}_{2} \quad \text { "Gostei bastante (muito) da farinha de milho temperada que vocês } \\
& \text { colocam nos alimentos." }
\end{aligned}
$$

a desorganização da colocação dos termos farinha, temperada e milho nessa frase caracteriza outro problema de natureza morfossintático-semântico.

Cabe lembrar que, em inglês, os modificadores do nome se posicionam normalmente à esquerda deste; em português, à direita. Atribuímos a confusão observada nos pronunciamentos de língua portuguesa ao condicionamento gramatical inglês, quanto à organização sintática automática dos termos do sintagma 
- uma lógica correspondente ou, pelo menos, próxima das normas da nova língua $\left(L_{2}\right)$ que facilita a expressão dos pensamentos dos falantes.

Nessa última fala apresentada, o enfoque nominal permanece, mas houve alterações na seqüência dos termos e nas formas dos modificadores, gerando assim incompreensão da fala. Nela, encontramos, também, um problema relacionado às escolhas lexicais inadequadas ao contexto: usaram-se as palavras farino, temporada e milhas por, respectivamente, farinha, temperada e milho.

Apreciemos a fala:

F1 I "Os homens de negócio estrangeiro passam muito tempo achando uma casa [...]."

Nota-se que, apesar de decodificável, essa fala cria um problema por não corresponder à intenção do falante. O deslocamento do componente estrangeiro, que passou a funcionar como modificador do adjunto adnominal, de negócio, altera a referência, sem, no entanto, causar propriamente uma ambigüidade. Trata-se de uma outra referência, embora a posição inadequada de núcleos e modificadores possa gerar uma certa confusão com ambigüidade.

Encontramos nessa construção um sintagma Os homens de negócio estrangeiro representando o sujeito da oração; um equívoco que pode ser caracterizado pelo deslocamento do enfoque nominal, dando margem a dois tipos de interpretação:

Os homens de negócios estrangeiros, onde estrangeiros se refere a negócios, afastando-se da intenção do falante.

e

Os homens estrangeiros de negócio, onde estrangeiros se refere a homens, aproximando-se mais da intenção do falante.

A intenção do falante corresponde em $\mathrm{L}_{2}$, à paráfrase:

F1 $L_{2} \quad$ "Os estrangeiros, homens de negócio, passam muito tempo [...]", onde homens de negócio funciona como aposto do núcleo nominal estrangeiros. 
Lembramos aqui que mudança de referência não pressupõe ambigüidade.

Convém, então, estabelecer a distinção entre esses dois conceitos. No primeiro ocorre, normalmente, o deslocamento de algum componente do sintagma, remetendo-nos a um tipo de interpretação diferente da que se propõe no contexto por não corresponder com a intenção do falante, sem, no entanto, criar dúvidas quanto à compreensão do texto em si. No segundo, a ambigüidade resulta da má estruturação do sintagma dificultando a decodificação do texto e comprometendo a informação, por permitir mais de um tipo de interpretação, o que vai obscurecer a intenção do falante.

Considerem-se as ocorrências:

F1 l "Os pais dos crianças brasileiros lá são de classe alta."

O problema de referência apresenta-se atrelado a dois enfoques nominais pais e crianças, o que gera dois tipos de interpretação:

- "Os pais das crianças brasileiras de lá [...]"

- "Os pais brasileiros das crianças de lá [...]"

onde encontramos, no primeiro caso brasileiras na função de adjunto adnominal de crianças e no segundo, brasileiros na função de adjunto adnominal de pais.

Na fala:

F2 I "[...] o sucesso inglês dos aulas [...] para encontrato outros alunos [...]"

A má estruturação dessa fala permite inferências diferentes, representadas pelos sintagmas:

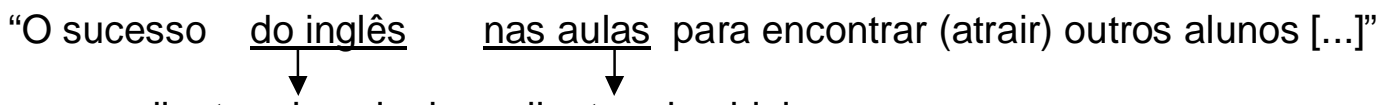
adjunto adnominal adjunto adverbial

"O sucesso das aulas de inglês para encontrar (atrair) outros alunos[...] adjunto adnominal adjunto adnominal 
No primeiro caso encontramos uma referência à língua inglesa: o sucesso da utilização do inglês nas aulas; as aulas não precisam ser de inglês, mas em inglês, isto é, podem ser de outra disciplina, em que se adotam recursos auxiliares ou abordagens em inglês.

No segundo, encontramos uma referência às aulas de inglês enquanto ensino-aprendizagem da língua inglesa.

\section{F3 I "[...] está muito difícil procurar uma professor bem de português." \\ $\mathrm{L}_{2} \quad$ "[...] é muito difícil encontrar um bom professor de português."}

Além da confusão morfológica entre o advérbio bem e o adjetivo bom aplicase, neste caso, a regra básica do português: posposição do adjetivo (bom), cujo efeito gera incongruência contextual pelo fato de ele aparecer na forma equivocada e agramatical de advérbio (bem), resultando em emprego não apropriado. Acrescenta-se, ainda, que essa fala admite outra eventual correspondência em $L_{2}$ :

F3 $\quad L_{2} \quad$ "[...] é muito difícil procurar bem um professor de português."

Relacionado ao uso do adjetivo bom, registramos:

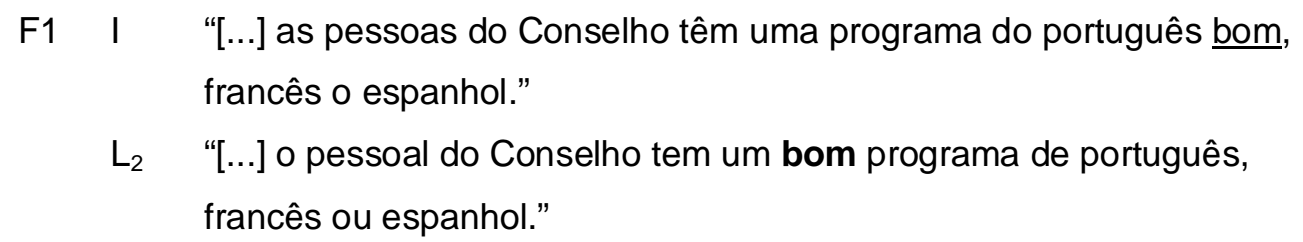

Trata-se aqui de uma ambigüidade, pois atribui-se ao adjetivo bom uma função diferente da que está subentendida no contexto: um bom programa de português, onde bom modifica programa e não português, como ficou estabelecido na fala que assinala novamente o erro da posposição do adjetivo ou, ainda, eventualmente uma interpretação diferente: "[...] é muito difícil procurar bem um professor de português." Toda a mencionada abertura semântica justifica-se pelo fato de a ocorrência com a qual estamos trabalhando, mostrar-se capaz de levar um falante de $L_{2}$, mais engajado nessas dificuldades lingüísticas, a inferir uma última e 
mais remota interpretação, onde o advérbio bem venha corresponder a "de maneira funcional, segura, sem risco de erros".

Consideramos, a seguir, a fala:

"A maior dificuldade para mim da língua é uma gramática."

Para tal enunciado encontramos duas interpretações:

"Para mim, a maior dificuldade da (na) língua está na gramática.", onde para mim significa " na minha opinião".

e

"A maior dificuldade para mim (a minha maior dificuldade) na língua está na. gramática "onde para mim, deve ser entendido como "que eu enfrento".

Conforme se observa o componente para mim é passível de dupla interpretação. Diretamente relacionado ao seu deslocamento e posição em um determinado lugar no texto, acarreta ambigüidade e problema de compreensão como na fala em questão. Portanto, componentes oracionais idênticos na $L_{2}$ podem sofrer alteração de significado por viabilizarem diferentes significados oracionais, quando deslocados pelo falante.

Nas três falas que seguem:

F1 I "Eu tinha com minha mulher no supermercado Brasil mais ou menos todas as coisas [...]."

$\mathrm{L}_{2} \quad$ "Eu comprei (consegui achar) no supermercado do Brasil [no supermercado daqui (do Brasil); aqui no Brasil] quase todas as coisas $[\ldots] . "$

F2 I "[...] Então o país do Brasil perder estes students [...]."

$\mathrm{L}_{2} \quad$ "[...] Então o Brasil (os cursos de inglês do Brasil) acabam perdendo os alunos [...]."

e

F3 I "[...] eu gosto bem dos pessoas do brasileiro."

$\mathrm{L}_{2} \quad$ "[...] eu gosto bastante dos brasileiros." 
verificamos que, na fala 1, na referência à compras realizadas no supermercado brasileiro, substituiu-se o adjetivo brasileiro por um sintagma, no supermercado do Brasil, que distancia o falante do mencionado país (o Brasil), como se ele não estivesse nele; na 2, no comentário sobre a evasão de alunos dos cursos de inglês no Brasil, a falta de síntese e objetividade acabam comprometendo a espontaneidade da fala. $\mathrm{Na} 3$, tem-se um sintagma mal estruturado, dos pessoas do brasileiro, em que o núcleo atualizado pela palavra genérica pessoas seguido de um modificador do brasileiro na forma inadequada de adjetivo e sem concordância de número com a base, deixou o elo introdutor tanto sem função lógica quanto sem função específica. Esses componentes da frase resultam em uma combinatória inaceitável pela falta de síntese da expressão do pensamento na forma de um simples adjetivo nominalizado, com a retirada do núcleo e do elo desnecessários.

Quanto ao emprego da palavra mundo como modificador de nome substantivo registramos três falas:

Fala 1:

F1 I "[...] aqui é possível ter uma concorda verbal [...] os sistemas do mundo [...] deferente."

$\mathrm{L}_{2} \quad$ "[...] aqui (em São Paulo) é possível fazer um acordo verbal, mas os sistemas mundiais são diferentes (isso não está previsto nos outros sistemas mundiais)."

F2 I "[...] mas os políticos do mundo têm o mesmo situação."

$\mathrm{L}_{2} \quad$ "[...] mas os políticos do mundo todo (inteiro) encontram-se na mesma situação."

F3 I "[...] (os povos) estão liderando idéia do mundo e tem uma lugar na mesa do mundo."

$\mathrm{L}_{2} \quad$ “...] (essas pessoas) estão liderando idéias (existentes no) do mundo inteiro (movimentos que ocorrem no mundo todo) e estão ocupando um lugar nas assembléias mundiais."

Nas três falas transcritas, notam-se quatro empregos da palavra mundo, que serão indicados na respectiva ordem de ocorrência, como primeiro, segundo, terceiro e quarto registros. 
No primeiro deles, a fala referente a acordos entre sistemas mundiais, e no quarto, no enunciado em que se fala sobre o movimento dos sem-terra, o referido modificador, funcionando como um adjunto adnominal, encerra um significado completo, apesar de não apresentar a mesma naturalidade alcançada pelo adjetivo correspondente mundiais, mais apropriado ao texto. Buscou-se como alternativa para comunicação, a expressão formada por preposição+substantivo, em ambos os casos: os sistemas do mundo e na mesa do mundo, como vemos na interlíngua.

No segundo registro, quando se comenta sobre as indefinições político partidárias, e no terceiro, sobre o movimento dos sem-terra, no entanto, encontramos ausência de componentes esclarecedores dos núcleos nominais pelos motivos adiante expostos.

Se considerarmos a $L_{2}$ desses dois últimos exemplos, vemos que 0 modificador do mundo na fala do entrevistado adquire um sentido vago, semanticamente insuficiente, quase se aproximando do pejorativo mundano, ou do menos expressivo mundial o que acabou truncando a informação. Um sintagma mais extenso, com o acréscimo do adjetivo inteiro ou todo, especificando a palavra mundo, teria caracterizado melhor os núcleos idéias e políticos, tornando as expressões mais precisas.

Ainda sobre o uso da palavra mundo observemos as falas:

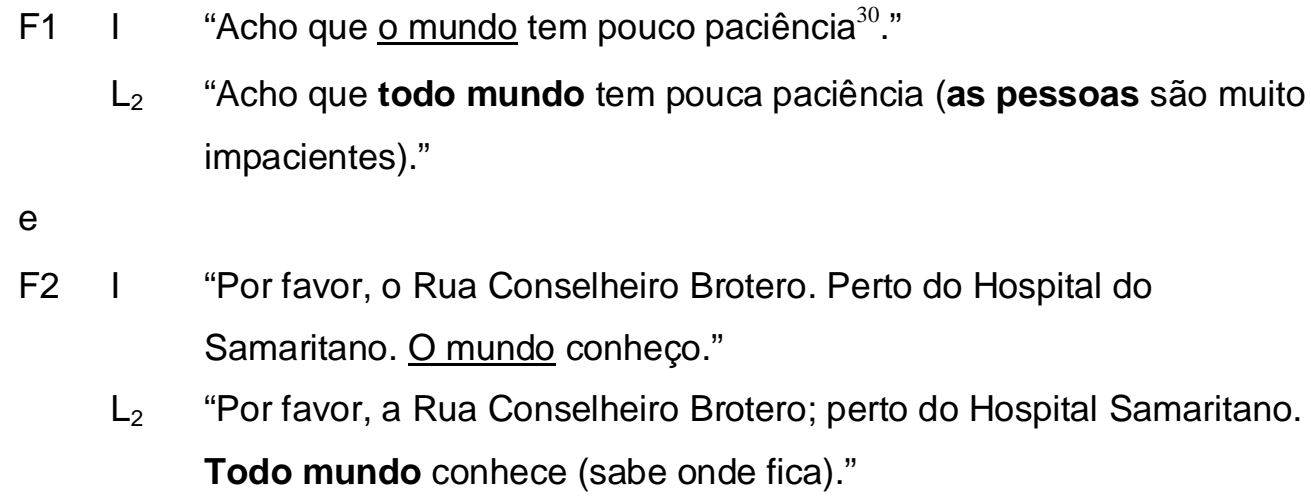

nas quais se apresentam, respectivamente, o estado de espírito das pessoas e a solicitação de informação a um motorista de taxi.

\footnotetext{
30 Novamente a expressão ter+substantivo = ter paciência invés de usar uma forma com o adjetivo correspondente: ser paciente.
} 
Apesar de a palavra mundo funcionar como núcleo e não como modificador do nome, em ambas as falas, cabe observar a idéia de totalidade nos referidos contextos e acrescentar que a presença da palavra mundo resulta de transformações em que ela ocorre como modificador de pessoas, na estrutura subjacente: todas as pessoas do mundo e todo mundo.

Do exposto verificou-se a dificuldade de relacionar núcleos (substantivos) e respectivos modificadores.

\subsubsection{Sintagmas adjetivais}

Dando seqüência às nossas investigações nas estruturas nominais, trataremos agora de sintagmas cujo núcleo corresponde a um adjetivo, os sintagmas adjetivais

Considerem-se as ocorrências:

F1 I "[...] porque o Cultura Inglesa é cheio dos estudantes."

$L_{2} \quad$ " $[\ldots]$ porque a Cultura Inglesa está cheia de estudantes."

e

F2 I "Português não é uma língua onde é fácil encontrar aulas."

$\mathrm{L}_{2} \quad$ "Português não é uma língua fácil de (se) encontrar aulas."

$\mathrm{Na}$ fala 1, a presença do artigo o em dos especificou o substantivo estudantes, apagando o sentido genérico a ele atribuído, conforme comprovado pelo contexto. $\mathrm{Na} 2$, apresenta-se uma estrutura, adjetivo+infinitivo, fácil encontrar, bem semelhante à da língua inglesa, portanto não se justifica o uso do pronome relativo onde, que ficou deslocado, sem relação nenhuma com os outros componentes do período. Esse descuido, no entanto, não dificultou a compreensão da mensagem.

Observe-se a fala:

F1 I "Esta parte do gramática é mais dificíl por as pessoas que fala inglês."

$L_{2} \quad$ "Esta parte da gramática é mais difícil para as pessoas que falam inglês 
Para as pessoas que falam inglês tem-se ainda as correspondências os falantes da língua Inglesa ou os falantes Ingleses ou simplesmente, os ingleses)."

Além da maneira prolixa de se referir aos falantes do inglês, por meio de uma oração adjetiva, que fala inglês, ao invés de uma forma concisa falantes sobrevivência do particípio presente, acrescenta-se uma confusão entre as preposições por e para: usou-se inadequadamente a preposição por (através de) em lugar de para, que expressaria adequadamente a idéia de finalidade presente no modificador.

Em:

F1 I "[...] para as crianças (inglesas) é pouco [...] é difícil entender a criança $[\ldots] . "$

$\mathrm{L}_{2} \quad$ "[...] entender a criança brasileira é um pouco difícil para as crianças inglesas [...]."

Esse texto expressa um pensamento confuso, quanto à seqüência sintática natural, tendo em vista uma comunicação mais fácil. Traz para a linguagem coloquial um recurso adotado no gênero poético: o hipérbato.

Em:

F1 I "É suficiente para comunicar esses pessoas área comercial."

$\mathrm{L}_{2} \quad$ "É suficiente para me comunicar (para a minha comunicação) com as pessoas da área comercial."

ou $\quad L_{2} \quad$ "É suficiente para a minha comunicação com as pessoas da área comercial."

Como já vimos ao tratar do infinitivo, essa forma nominal pode corresponder a um substantivo.

Confirmou-se pelas ocorrências apresentadas a incapacidade de localização dos núcleos nominais (substantivos e adjetivos) e de combinação de seus legítimos modificadores. 


\subsubsection{Classes de palavras: usos e inter-relações}

Cabe acrescentar aos nossos comentários outros procedimentos lingüísticos usados pelos falantes, com vistas à comunicação, através de suas falas.

Esses recursos alternativos confirmam as reiteradas dificuldades dos falantes em localizar e trabalhar com uma determinada classe de palavras.

Confira-se:

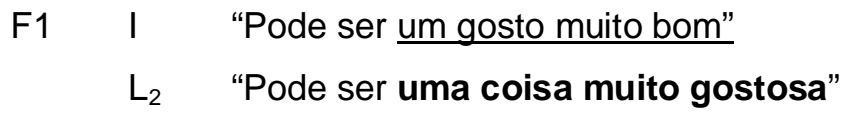

Gosto muito bom é usado para significar "coisa muito gostosa". Apesar de ter havido comunicação, contorna-se a situação no que diz respeito à formação de adjetivos em -oso(a) pelo uso de uma expressão estranha e incomum, gosto muito bom, em vez de uma estrutura simples e freqüente em português, coisa muito gostosa, sugerida em $\mathrm{L}_{2}$.

F2 I "Eu acho que de novo eu vou fazer uma procuração com muitos detalhes com professor",

$\mathrm{L}_{2} \quad$ "Eu acho que vou fazer novamente uma busca detalhada de professor."

Nessa fala os sintagmas adverbiais de novo (prep+adj) e com muitos detalhes (prep+subst) poderiam ser substituídos, respectivamente, pelo advérbio novamente (adjetivo, novo+sufixo -mente) e pelo adjetivo detalhada (verbo detalhar+sufixo do), provavelmente de difícil criação.

Esses recursos alternativos que vêm se revelando através deste trabalho refletem dificuldade na localização e no manuseio de determinadas classes de palavras.

Verifica-se uma procura reincidente, de expressões com um maior número de palavras - uma alternativa prolixa de representar os pensamentos, chegando, muitas vezes, a redundâncias e até mesmo ao estabelecimento de ambigüidades, como já visto. 
Expressões com verbo+substantivo, verbo+adjetivo constituem paráfrases criadas para substituir os verbos, outras vezes os substantivos, os adjetivos e até os advérbios não assimilados, de difícil escolha ou mesmo de localização no inventário lexical (busca na memória), o que nos leva a concluir que essa tendência de opção por formas analíticas, reveladora de defeitos quanto ao discernimento de classes, se justifique pela insuficiência de treinamento relativo à derivação por sufixação uma prática, imprescíndivel aos ensinos morfológicos, voltada à multiplicação de palavras pelo acréscimo de sufixos, que colabora com o enriquecimento do vocabulário, evitando assim paráfrases alternativas desnecessárias.

Verificamos, assim, uma dificuldade, que envolve a distinção entre as classes de palavras: substantivo, adjetivo, advérbio e respectivas interrelações, para a criação de expressões compatíveis com o contexto, dando vigor e naturalidade à fala.

\subsubsection{Casos específicos}

Outros casos mais específicos de usos alternativos seguem agrupados sob as rubricas que caracterizam os tipos de desvios de expressão: ampliação, redução, substituição, complementação e generalização. As justificativas desses blocos destinam-se a demonstrar a origem dos problemas que descaracterizaram a disciplina lingüística autorizada e aceitável em conformidade com as áreas da morfologia, sintaxe e semântica.

\subsection{Ampliação}

Notem-se as correspondências:

INTERLÍNGUA

"Eu tenho lágrimas"
$\mathrm{L}_{2}$

"Eu choro" 
"Ele não tem uma trabalho aqui."

"Com você tem um casamento."

"dar resposta"

"Ficar com apartamento"

"Ficar com televisão"

"Tudos fica bobage"

"Estar atrasado"

me senti infeliz

"Senti falta para ser fluente"

"Eu tinha uma sentido isolação"

"[...] tem diferência da Inglaterra"

"As pessoas vivem juntos ao lado do outro"

"Ambas no Brasil estes país

estrangeiros também"

"Português da rua"

"os povos em todo o mundo"

"Nas áreas do público"

"As pessoas do Brasil"

"O país do Brasil"

"o menino da loja"

"Coisa que parece simples"
"Ele não trabalha aqui."

"Quando você se casa."

"Responder"

"Hospedar-se"

"Ficar assistindo televisão"

"Não resolve (não soluciona) nada"

"Atrasar-se"

"Sofri muito"

"Senti falta de fluência"

"Eu me sentia sozinha"

"É diferente da Inglaterra"

"As pessoas são solidárias"

"Ambas no Brasil e em outros países

também"

"Português coloquial, informal"

"As população mundial"

"Nas áreas públicas"

"Os brasileiros"

"O Brasil"

"O vendedor"

"Coisa aparentemente simples"

Os recursos precedentes revelam uma dificuldade na manipulação das relações lexicais para o estabelecimento das prioridades na escolha da classe de palavras, para que estas assumam com mais propriedade uma determinada função dentro de um texto. As disponibilidades existentes no universo lexical sugerem alternativas que venham representar melhor as idéias, e assim facilitar sua comunicação, em um determinado contexto. Para isso, dever-se-á observar mais atentamente o desempenho aceitável da classe escolhida, tomando como base suas possíveis funções, pré-estabelecidas pela gramática. Significa, portanto, saber distinguir as diferentes classes de palavras e aplicá-las de maneira mais conveniente às normas gramaticais, como meio funcional de traduzirmos a intenção do falante. 
Em toda essa enumeração de recursos alternativos apresentada existe uma dificuldade latente, que pode ser facilmente inferida por um estudioso dessas falas: dificuldade em sintetizar idéias.

Observe-se agora a fala:

$\begin{array}{lll}\text { F1 I "Demora muito a burocracia aqui" } & \\ & L_{2} \quad \text { "A burocracia aqui é muito demorada" }\end{array}$

Empregou-se nessa fala, na interlíngua, a burocracia -como sujeito agente ao invés de sujeito paciente.

Aplica-se nesse caso uma situação inversa à anterior, um contexto que admitiria uma expressão verbo+adjetivo, ser demorada, ao invés de usar essa paráfrase, optou-se pelo verbo correspondente, demorar, criando uma oração, em que o sujeito vai assumir uma função (agente) em desacordo com o raciocínio lógico-gramatical (paciente) - resultando em um erro.

\subsection{Redução}

Considerem-se as falas:
F1 l "Responsabilidade dos assuntos educação"
$\mathrm{L}_{2} \quad$ "Responsabilidade pelos assuntos sobre (de) educação (educacionais)"

F2 I eu fiquei vontade aqui.

$\mathrm{L}_{2}$ eu fiquei à vontade (descontraída, relaxada) aqui.
F3 I "eu estou (falando) confiança"
$\mathrm{L}_{2} \quad$ "eu estou (falando) em confiança (confidencialmente)"




\section{F4 I Talento dos vivar estrangeiro \\ $\mathrm{L}_{2} \quad$ talento para viver no estrangeiro \\ $\begin{array}{lll}\text { F5 } & \mathrm{I} & \text { contratos papel } \\ & \mathrm{L}_{2} & \text { Contratos por escrito (no papel, assinados) }\end{array}$ \\ e \\ F6 I para com os coletivo \\ $\mathrm{L}_{2} \quad$ com a coletividade (o público, o povo em geral)}

Encontramos, nos primeiro e terceiro exemplos, um problema sintático configurado pela ausência dos elementos de relação representados pelas preposições sobre e em respectivamente. Nos segundo e quarto, omitem-se as formas à e no (contração e combinação respectivamente) indispensáveis à composição aceitável do sintagma. No quinto exemplo, uma inadequação na escolha lexical: papel em lugar da expressão por escrito, assinado, configurando-se num problema morfossemântico, conforme se verifica em $L_{2}$. No sexto, uma opção lexical inadequada, coletivo, para a referência ao povo, à sociedade, decorre da nominalização do adjetivo no plural, deixando essa marca somente no determinante os, sem a devida concordância nominal, os coletivo. Esses recursos denunciam a dificuldade na criação do substantivo coletividade. Trata-se de uma tendência contrária à anteriormente vista, voltada, agora, especificamente aos substantivos que aparecem isolados e desprovidos da necessária roupagem sintagmática - sem modificadores havendo, portanto, uma redução da expressão.

De maneira geral, podemos inferir e incluir em toda a apresentação dessas falas, também, uma falha basicamente relacionada aos verbos, com respeito à distinção entre verbo/deverbal (substantivo)/adjetivos derivados de verbos.

Demonstra-se o problema não só nas respectivas transformações morfológicas como também em realizações complicadas, com marcas de provável ineficiência nas técnicas aplicadas de como estabelecer relações entre classes de palavras, entre certas palavras de mesma família lexical (mesmas raízes lexicais) o que vem justificar a tão reincidente ausência das formas de derivação de adjetivos que vimos observando nos registros dos entrevistados. Esse fato pode, ainda, ser atribuído novamente à pouca ênfase nas práticas e utilização adequada dos recursos disponíveis, voltados à palavra e condicionamento de suas possíveis 
funções para alcançar uma aceitável contextualização em língua portuguesa, portanto, um problema que recai mais especificamente na seleção, compreensão e retenção das relações morfossintáticas básicas do discurso.

\subsection{Substituição}

Desse procedimento registramos:

F1 I "Aquele negócio onde [...] eu fico no cavalo bom"

$\mathrm{L}_{2} \quad$ "Aquele negócio onde eu fico bem no cavalo"

e

F2 I "o coisa a gente usam no peito [...] na gar [...]"

$\mathrm{L}_{2} \quad$ "essa coisa que as pessoas usam no pescoço [...]"

Nesses casos, criam-se formas mais extensas de expressão - verdadeiras definições - para substituírem os substantivos não localizados ou não lembrados e assim suprir deficiências de vocabulário. Nota-se o emprego desses recursos em 1 e 2, para substituir, respectivamente, as palavras cela e colar.

\subsection{Complementação}

Quanto à complementação temos:

F1 I "[...] agora eu vou desenvolver uma sistema muito bom."

$L_{2} \quad$ um sistema de ensino e aprendizagem, uma técnica de ensino e aprendizagem, uma metodologia funcional."

F2 I "Nós não tínhamos cultura."

$\mathrm{L}_{2} \quad$ "cultura lingüística, uma formação lingüística." 

F3 I "Eles não tinha uma percepção."
$L_{2} \quad$ "uma percepção para entender o necessário, uma capacidade de perceber o prioritário para o aluno."

F4 I "Eu não sou chefe bem mas eu tenho uma quadra, um quadro [...]"

L2 "um quadro de funcionários, equipe de funcionários."

F5 I "Você não tem conhecimento com sua quadra."

$\mathrm{L}_{2} \quad$ "conhecimento para dialogar, boa comunicação."

F6 I " [...] porque nós não temos uma estrutura ou forma, mas eu acho que eu aprende.

$\mathrm{L}_{2} \quad$ "forma adequada de aprendizagem."

e

F7 I "Realmente as aulas não tinha um tema."

$L_{2} \quad$ "plano de ensino."

Nesses registros, adotam-se mecanismos merecedores de atenção devido à insuficiência de informação, atribuída a uma incapacidade lingüística que impede a composição de seqüências sintagmáticas facilitadoras da comunicação., daí a opção pelo uso de palavras como sistema, cultura, percepção, quadra, conhecimento, estrutura e tema, que pelo seu caráter genérico e vago requerem transitividade, pois necessitam de uma complementação ou eventualmente de uma paráfrase esclarecedora. Mais especificamente, expressões que se acham implícitas no contexto aparecem mal estruturadas na fala - correspondem a sintagmas truncados que se restringem ao núcleo nominal, sem os devidos modificadores.

\subsection{Generalização}

No que se refere à generalização verifiquem-se: 


\section{F1 I " [...] como fazem outros partes, incluindo a Inglaterra" \\ $\mathrm{L}_{2} \quad$ "outros países" \\ F2 I "Esso é uma parte de Consulado"
$\mathrm{L}_{2} \quad$ "responsabilidade do Consulado"}

F3 I "[...] e a muitos partes governo da Escócia"

$\mathrm{L}_{2} \quad$ "setores, órgãos do governo"

$\begin{array}{lll}\text { F4 I } & \text { "A falta é na área comum, nas ruas [...]" } \\ & \mathrm{L}_{2} \quad \text { "nos lugares, ambientes comuns, fora da Embaixada" }\end{array}$

F5 I "Então na área de bares, restaurantes encontra outras pessoas fora da área do trabalho $[\ldots] "$

$\mathrm{L}_{2}$ "região - local"

F6 I "uma das áreas onde inglês é conhecido"

$\mathrm{L}_{2} \quad$ "países, lugares"

F7 Ì " $\quad[\ldots]$ outras áreas além do trabalho [...]"

$\mathrm{L}_{2} \quad$ "atividades"

F8 I "Nós moremos na área de 1 mundo"

$\mathrm{L}_{2} \quad$ "bairro nobre, de classe alta"

F9 I "[...] têm muitos transtornos do trânsito, de áreas de violência [...]" $\mathrm{L}_{2} \quad$ "riscos de violência"

Essas ocorrências confirmam a opção pela substituição, pois os substantivos genéricos partes e área(s) substituem os mais específicos e adequados em $\mathrm{L}_{2}$. A palavra partes compensa generalizando: países, responsabilidade, setores, ("órgãos"), lugares ("ambientes") e área(s) generalizando região ('local"), países ('lugares"), atividades, bairro nobre e riscos. 
O recurso à generalização vem se apresentando de forma muito comum nas falas registradas. Corresponde à utilização de palavras abrangentes, motivada por desconhecimento das mais apropriadas e específicas. Por esse motivo, verifica-se uma restrição de escolhas identificadas pela marca quase vazia, uma maneira de designar os vocábulos que, pela baixa expressividade semântica, conseguem atingir somente um nível de informação superficial e vago.

\subsection{Inadequação}

Quanto à inadequação, merecem também destaque as ocorrências registradas nos três casos que seguem:

1ํ caso:

F1 I "São Paulo tem o festa do filmes jurídica muito interessante."

$\mathrm{L}_{2} \quad$ "São Paulo tem o festival de filmes para julgamento (crítica dos mesmos), o qual é muito interessante."

Encontramos nessa fala um problema causado pelo emprego inadvertido da classe de palavras: usa-se um adjetivo jurídica em lugar de uma expressão para julgamento que ficam mais distanciados ainda pela restrita aproximação semântica entre eles - uma relação sinonímica incompleta.

Por falta de localização de uma expressão que pudesse corresponder à avaliação crítica criou-se uma palavra - um adjetivo real - mas que, pelo seu alto grau de estranheza dentro do contexto por não apresentar qualquer relação morfossintática com os componentes frasais próximos a ele, não pode assumir objetivamente sua função de atributo e acabou ficando isolado. No entanto, uma leve associação semântica entre os elementos do texto nos levou a inferir uma paráfrase desse adjetivo: para julgamento ("crítica dos filmes"), bem próximo à intenção do falante. 
2ำ Caso:

F1 I "Eu não tem certeza [...] você vai usar por uma outra assunto."

$\mathrm{L}_{2} \quad$ "Eu não estou tranqüila (estou preocupada, nervosa) porque você pode usar (esta entrevista) para uma outra finalidade."

e

F2 I "Felizmente o menino da loja falou um pouco inglês e nós realmente tem bem sucesso com os roupas formal."

$\mathrm{L}_{2} \quad$ "Felizmente o vendedor falava um pouco de inglês e nós conseguimos nos comunicar muito bem na compra das roupas formais."

Essas falas têm em comum uma expressão alternativa, formada pelo verbo ter+substantivo, mas se distanciam significativamente, da intenção do falante.

Em 1, a expressão ter certeza, não se adéqua ao contexto, poderia ter garantido ajuste semântico e correção em estruturas passíveis de construção composições sintáticas disponíveis na língua, mas aparentemente inacessíveis aos falantes, formadas por ser/estar+adjetivo, estar tranqüilo como vemos em $L_{2}$. Vimos observando o contrário: ser muito comum expressões do tipo ter+substantivo apoiarem-se em paráfrases correspondentes à combinação de ser/estar+adjetivo em busca de maior objetividade e mais fácil decodificação das formas de transmissão de mensagens, como ficou bastante acentuado em nossos textos teóricos.

Em 2, verifica-se a expressão ter sucesso em lugar de um verbo comunicarse, que não ocorreu no ato da fala, resultando uma absoluta incompatibilidade em relação à verdadeira intenção do falante, impedindo ainda a decodificação da mensagem.

3ำ caso:

F1 I "Eu prefero de ficar voando, conhecendo lugar desde (from) o ar."

$\mathrm{L}_{2} \quad$ "Eu prefiro ficar voando, conhecendo lugares lá de cima (do alto)."

Além da forma inusitada desde o ar, demonstrando uma influência direta da preposição from (indicadora de origem), encontrada na expressão inglesa from 
above, esse recurso apresenta, ainda, uma inadequação semântica no substantivo ar.

\subsubsection{Nominalizações: improcedências}

Este item destina-se ao levantamento dos erros limitados às inadequações relativas aos nomes e às formas nominais a eles relacionadas. Apresentar-se-ão agrupados sob as rubricas: nomes: formação dos substantivos, formas nominais e formas nominalizadas (deverbais).

3.1.6.1 Nomes: formação dos substantivos

Quanto à formação dos substantivos, despertaram nossa atenção as seguintes ocorrências:

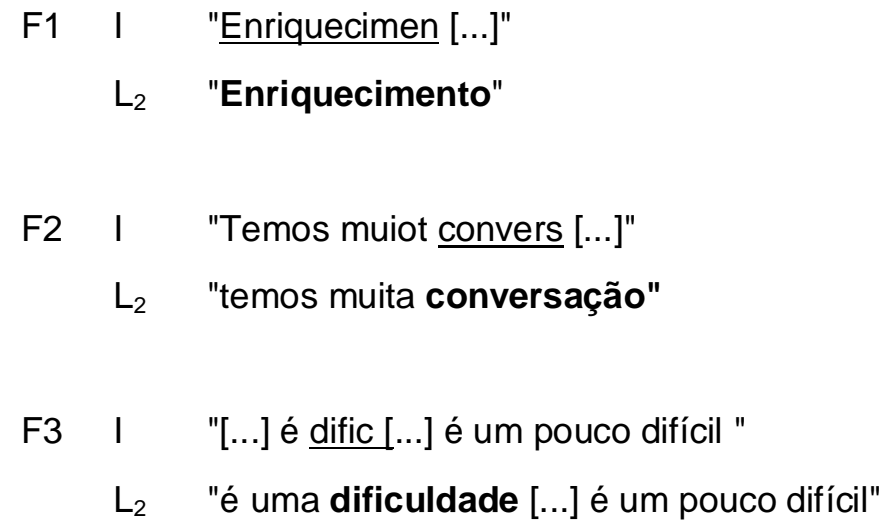

Nesses casos uma dificuldade no acréscimo dos sufixos -mento, -são e /i/dade originou uma interrupção da fala.

Esse mesmo recurso à interrupção, embora não se trate de um processo de transformação por sufixação, ocorre em: usar uma fotogra [...] por usar uma fotografia (foto) apesar da semelhança com o inglês photography [...] e da possibilidade de se usar a forma reduzida e mais popular photo: 


\section{F1 I "Usar um fotagra [...]" \\ $L_{2} \quad$ "usar uma fotografia (foto)"}

Já em

$$
\begin{array}{lll}
\mathrm{F} 1 & \mathrm{I} & \text { "Este cult }[\ldots] \text { coisas" } \\
& \mathrm{L}_{2} & \text { "essas coisas culturais (complicações culturais)" }
\end{array}
$$

Ocorre a expressão este cult [...] coisas. Embora não possamos precisar se o falante intencionava usar um adjetivo ou um substantivo, estabelecemos a correspondência com essas coisas culturais ("complicações culturais").

Queremos crer que neste caso houve um condicionamento à seqüência encontrada na língua inglesa, problema esse relacionado com a sintaxe de colocação do inglês: [caracterizador (adjetivo)+coisa caracterizada (substantivo)].

Esse referido caracterizador, no entanto, eventualmente se construiria e realizaria de forma inadequada, isto é, através do substantivo cultura, um substantivo antes de substantivo, seqüência muitas vezes registrada através das falas observadas.

Essas dificuldades, que atribuímos a uma indecisão diante da forma apropriada a ser escolhida pelo falante, levaram-nos a agrupar e comentar as inadequações de acordo com as ocorrências relativas à formação de palavras por derivação sufixal, subentendendo-se os acréscimos de sufixos e, ainda, o caso relacionado à redução dos mesmos.

\subsection{Derivação sufixal}

Atentemos para a formação sufixal dos nomes-substantivos cuja seqüência se apresenta encabeçada pelos sufixos de maior produtividade:

a) sufixo -MENTO 


\section{F1 I "entretenimiento" \\ $L_{2} \quad$ "entretenimento" \\ F2 I "estudamento" \\ $\mathrm{L}_{2} \quad$ "estudo (análise)" \\ F3 I "um aprendimento visual" \\ $\mathrm{L}_{2} \quad$ "uma aprendizagem visual"}

Nota-se em 1, entretenimiento o uso de uma forma por influência do sufixo espanhol -miento; em 2, uma formação por sufixação estudamento no lugar de um deverbal estudo e em 3, aprendimento uma substituição do sufixo -agem por -mento, por ambos apresentarem o mesmo valor semântico. Constata-se o reconhecimento do radical aprend- , mas um erro na escolha do sufixo.

b) sufixo -AGEM

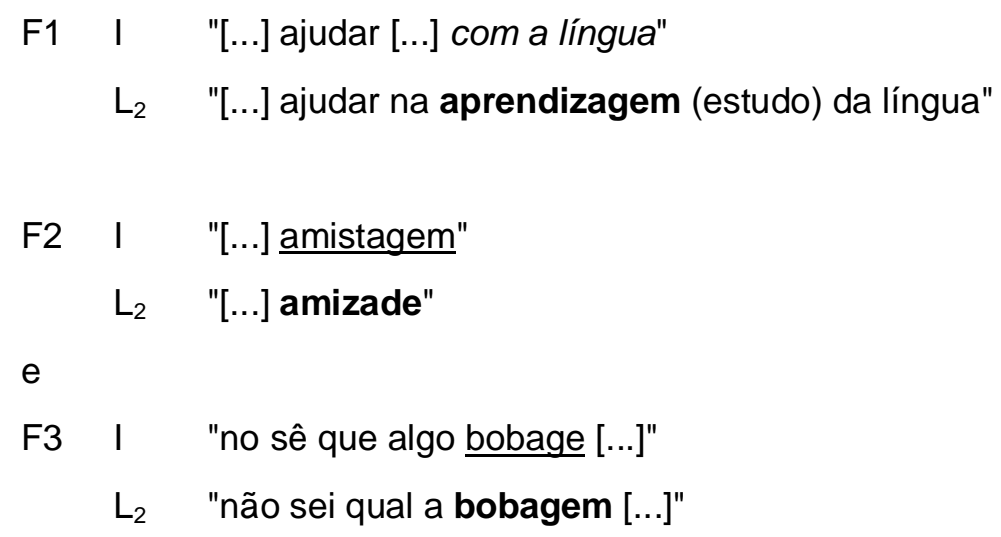

Em 1, interrompe-se a fala por falta de localização da palavra adequada, de acordo com o contexto, aprendizagem; em 2, forma-se um substantivo amistagem indevidamente, a partir do espanhol amistad acrescido do sufixo -agem em vez de ade e em 3, bobage, omite-se naturalmente a nasal $-m$ final durante a fala, um brasileirismo muito freqüente.

Registramos ainda o uso da palavra sacanagem com sentido de "malandragem" em: 


\section{F1 I "sacanagem" \\ $\mathrm{L}_{2} \quad$ "malandragem (safadeza)"}

Apesar de correta a formação da palavra sacanagem e da sua adequação ao contexto, usou-se, por aproximação do sufixo -agem, um vocábulo que perdeu o significado anterior de "vulgar", "pejorativo", portanto, já negativo, e acabou adquirindo, como vemos atualmente, um novo sentido ainda mais torpe e inconveniente.

Nos casos apresentados incluem-se além de registro de ausência, de mistura de línguas e de dificuldade fonética, o uso inadequado de palavras terminadas em agem.

c) sufixos -ÇÃO, -SÃO

Usou-se, entre outras, nas falas dos entrevistados, a palavra transportação por transporte por influência do inglês transportation e do espanhol transportación. Ocorre assim uma adaptação imprópria pelo acréscimo do sufixo -ação em substituição ao -action do inglês, atrelado ao radical transport-, provocando um abrasileiramento inadequado, usado no lugar de uma derivação regressiva, o deverbal, transporte.

Ainda por influência das palavras inglesas: integration, action, communication, em lugar do uso da derivação regressiva, o deverbal conversa (bate-papo), nota-se a suprageneralização através do sufixo -ção em conversação.

Confira-se a série a seguir:

$\begin{array}{ll}\text { ESPANHOL } & \mathrm{L}_{2} \\ \text { "transportación" } & \text { "transporte" } \\ \text { "educación" } & \text { "educação" } \\ \text { "atención" } & \text { "atenção" } \\ \text { "discussión" } & \text { "discussão" } \\ \text { "selección" } & \text { "seleção" } \\ \text { "percussión" } & \text { "percussão" } \\ \text { "fundación" } & \text { "fundação" } \\ \text { "televisión" } & \text { "televisão" } \\ \text { "acción" } & \text { "ação" }\end{array}$


Os sufixos como -ção, -são foram corretamente empregados pelos entrevistados através de espanholismos. Tal procedimento, porém, não deixa de revelar um conhecimento em potencial de suas respectivas correspondências em português, o que garantiria uma aprendizagem automática de derivações, já que as duas línguas são bastante semelhantes. O uso da palavra discriminação (com sufixo português), por exemplo, empregada com bastante pertinência e adequação contextual pelos entrevistados, vem reforçar essas inferências. Mesmo existindo a forma discrimination em Inglês e aventando-se a possibilidade de o entrevistado ter substituído o sufixo -ation por -ação, seu emprego se enquadra de maneira admissível e natural, sem a estranheza encontrada no uso da palavra transportação.

d) sufixo -ISMO

$$
\begin{array}{lll}
\text { F1 } & \text { I } & \text { "sexismo" } \\
& \mathrm{L}_{2} & \text { "sexualidade" } \\
& & \\
\text { F2 } & \mathrm{I} & \text { "egoism- + -o" } \\
& \mathrm{L}_{2} & \text { "egoísmo" } \\
& & \\
\text { F3 } & \mathrm{I} & \text { "o dinâmico" } \\
& \mathrm{L}_{2} & \text { "o dinamismo" }
\end{array}
$$

Pelo fato de o entrevistado usar sexismo ao invés de sexualidade, observa-se a formação inadequada do substantivo, através do emprego de uma palavra da língua inglesa sex, acrescida do sufixo português -ismo. Ocorre uma suprageneralização, pela associação com as palavras feminismo, machismo; portanto, [sex+-ismo]. Revela-se assim a tendência de acrescentar aleatoriamente os sufixos.

Nota-se, entretanto, que em uma das falas a palavra egoísmo foi corretamente usada. Nesse caso o aportuguesamento, através do acréscimo da desinência -o à palavra inglesa: egoism, ocorreu com bastante procedência.

Ressalta-se ainda o uso do adjetivo dinâmico no lugar do substantivo dinamismo. Percebe-se uma dificuldade na derivação do substantivo através do 
acréscimo do sufixo -ismo a um adjetivo, dinâmico, pelo provável desconhecimento dessa transformação que poderia espelhar-se em fanático (adj)/fanatismo (subst).

As ocorrências relacionadas ao sufixo -ismo registram situações diferentes das anteriormente apresentadas a respeito de -ção e -são: o referido sufixo surpreende-nos por aparecer em contextos que exibem, por um lado, associações lexicais improcedentes gerando inadequações morfológicas e, por outro, transformações corretas e aceitáveis.

e) sufixos -DADE, -///DADE

Destacam-se nesse caso:

$\begin{array}{lll}\text { F1 } & \text { I } & \text { "sexismo" } \\ & \mathrm{L}_{2} & \text { "sexualidade" } \\ & & \\ \text { F2 } & \mathrm{I} & \text { "igualidade" } \\ & \mathrm{L}_{2} & \text { "igualdade" }\end{array}$

Em sexismo, estabeleceu-se uma relação improcedente da palavra inglesa sex com o sufixo -ismo da $\mathrm{L}_{2}$, acarretando um problema de ordem morfológica.

Revela-se uma dificuldade na formação de substantivos derivados de adjetivos, pelo acréscimo do sufixo -/i/dade, a exemplo das formas:

$\begin{array}{ll}\text { Fácil } & \text { Facilidade } \\ \text { Hábil } & \text { Habilidade } \\ \text { Sexual } & \text { Sexualidade }\end{array}$

Note-se, porém:

Igualidade igualdade

A exemplo de

Igual [igualidade(?)] igualdade

Cruel [cruelidade(?)] crueldade ${ }^{31}$

\footnotetext{
${ }^{31}$ O ponto de interrogação não significa dúvida, mas um sinal caracterizador de formas que fogem ao padrão de transformações etimológicas.
} 
Em igualidade cria-se uma palavra que foge ao padrão de transformações etimológicas sofridas por outras palavras semelhantes em que o acréscimo da vogal de ligação - $i$ - é indispensável, como anteriormente observado.

Esse fato, provavelmente influenciou as escolhas do falante, gerando interferências.

Devemos observar que:

- a generalização pode trazer problemas a alguns casos específicos;

-a confusão pode ser criada por algumas divergências entre as línguas inglesa e portuguesa, como no caso de penalty e equality do inglês correspondentes, respectivamente, à penalidade e igualdade em português, que apresentam uma incoerência no resultado de suas transformações.

f) sufixos -ADO e -ADA

Quanto ao sufixo -ado(a) e -(VT a)-do(a), registam-se:

1- "A maioria são um mexilado"

2-" Um maestro na Saúde Pública"

3- "Uma descansa"

4- "[...] mas da cultura, da temporada

$[\ldots]$ "a maioria é um mesclado"

(mezclado - influência espanhola) -

"mistura"

"um mestrado em Saúde Pública"

"Uma descansada" (uma relaxada, um descanso)

"[...] quanto à cultura, ao tempo meteorológico" (clima) [...]

Lembramos que a desinência -do, terminação do particípio em português, é uma forma normalmente associada, pelos falantes, ao sufixo -ado, por analogia com a primeira conjugação. Aparece com freqüência, em $L_{2}$, na fala cotidiana em palavras como certificado, doutorado, entre outras. Daí o emprego de mexilado.

Ao utilizar mexilado pelo deverbal mistura, o abrasileiramento, de maneira imprópria, acreditamos ter sido inspirado no espanhol mezclado. Gerou-se, nesse 
caso, uma forma híbrida mexilado ( mexer + mesclado ), oriunda de uma provável contaminação sonora por analogia ao par de verbos mexer / mesclar. Essa possibilidade origina-se de uma já registrada confusão entre os mencionados verbos, atribuída a uma aproximação morfossemântica, apesar de estreita, existente entre eles.

No caso de maestro, o falante não localizando o termo adequado ao contexto, usou maestro por mestrado. Faz-se a associação com a palavra espanhola maestro, que significa "professor", "mestre", "perito num assunto ou matéria" o que acarretou uma incompatibilidade léxico-semântica ao contexto.

Os sufixos -ado e -ada, formadores de substantivos coletivos, entre outros, se caracterizam por uma idéia consumada, irreversível ${ }^{32}$. São referências restritas a informações ainda embrionárias diante de suas abrangências semânticas. Esse sufixo, contudo, na forma do feminino -ada, ganha outros significados, adquirindo uma mudança semântica voltada para o superficial, com se verifica em palavras como (uma) lavada, (uma) descansada. ${ }^{33}$

Em uma descansa, erra-se o gênero masculino do deverbal. Há, entretanto, o acerto quanto ao gênero feminino das palavras terminadas em -ado, apesar de não se ter efetuado a derivação através da desinência do particípio - do, no feminino para criar a palavra descansada mais apropriada ao contexto.

A palavra temporada, registrada em: [...] mas da cultura, da temporada [...], formada impropriamente como se fosse uma derivação sufixal, adquire um sentido diferente, que corresponde em $L_{2}$, nesse caso, a um determinado período de tempo, "um espaço de tempo, com começo, meio e fim" e não com o sentido de "clima" como pretendia o falante.

g) sufixo -ÊNCIA

Da sufixação por meio de -ência registramos:

\footnotetext{
${ }^{32}$ Sobre irreversibilidade, associada à forma do particípio passivo, consulte-se ULLMANN, 1964)

33 Segundo Stephen Ullmann (1964, Cap. III), em relação ao sufixo -ada, parece existir uma nuance de irreversibilidade no genérico pelas características de extensão e abrangência e, portanto, menor possibilidade de volta, implícitas nesse conceito. A idéia de irreversibilidade, encontrada nas formas consumadas da voz passiva, representadas pelo particípio, acaba se estendendo para o genérico. A partir daí e ainda relacionado a esse conceito, o sufixo -ada evoluiu, ganhou outros significados, e acabou adquirindo uma nuance semântica volada para o superficial como em (uma) descansada.
} 


\section{F1 I "Uma diferência muito grande" \\ $\mathrm{L}_{2} \quad$ "Uma diferença muito grande" \\ F2 I "falo meio Portinhol, mas já pacência" \\ $\mathrm{L}_{2} \quad$ "falo meio Portunhol, mas [...] paciência"}

Em diferênciia cria-se um ditongo -ia, uma inadequação resultante da influência espanhola de palavras como diferencia, da confusão com a acentuação tônica portuguesa e também da suprageneralização.

Além disso observa-se uma generalização inadequada devida ao uso do sufixo -ência, por associação a outros grupos de palavras como tendência, freqüência e ausência, entre outras.

Quanto à pacência, verifica-se outro tipo de problema, a redução do ditongo ie nasalado da penúltima sílaba, ocasionado pela mesma associação do caso anterior.

Outra hipótese viável é ter havido uma mistura de sufixos por associação morfológica a pares de palavras que apresentam uma relação semântica, mesmo com características opostas como vemos em ausência e presença.

Verificam-se, por um lado, no uso do sufixo -ência, alterações na estrutura das palavras, devido a criações desnecessárias de ditongos e, por outro, a susência da ditongação necessária.

h) sufixo -EZA

O sufixo -eza aparece em:

$\begin{array}{lll}\text { F1 } & \text { I } & \text { "Naturaleza" } \\ & \mathrm{L}_{2} & \text { "Natureza" }\end{array}$

Verifica-se em naturaleza, além da influência da identidade de forma com o espanhol, a formação imprópria do substantivo a partir do adjetivo natural ao qual se atrelou o sufixo -eza, à semelhança de belo/beleza; pobre/pobreza, donde: 
Já no caso:

$\begin{array}{lll}\text { F1 l } & \text { "Eu sento triste [...], eu sento saudade" } \\ & L_{2} \quad \text { "Eu sinto tristeza, eu sinto saudade" }\end{array}$

a dificuldade na formação de substantivos através do uso desse sufixo. Evidencia-se aqui a improcedência na formação de substantivos pelo acréscimo do sufixo -eza.

\subsection{Derivação por redução}

Deste procedimento registra-se apenas:

$\begin{array}{lll}\text { F1 } & \text { I } & \text { "Usar um fotogra [...]," } \\ & \mathrm{L}_{2} & \text { "usar uma fotografia (foto)," }\end{array}$

Apesar de fotografia ser uma forma bastante semelhante a do inglês photograph, trunca-se a palavra. Nota-se uma insegurança diante da possibilidade de se usar uma forma reduzida e mais popular, como é o caso de foto.

\subsubsection{Formas nominais}

Neste item, dedicamos especial atenção à geração de substantivos, às formas nominais (nominalizadas) de gerúndio, infinitivo e particípio.

\section{a) gerúndio}

Dentre as manifestações verbais dos entrevistados, registramos um uso aleatório do gerúndio: 
F1 I "eles conseguem entender a gramática, mas eles estão escutando e aprendendo; eles não estão falando e aprendendo [...] por isso [...] não estão praticando."

$\mathrm{L}_{2} \quad$ "eles conseguem entender a gramática, mas ficam só ouvindo sem praticar a fala."

Esse texto nos sugere a dificuldade nas nominalizações, - na construção das formas nominalizadas tais como fala, aprendizagem e prática, que enriquecem a estrutura do texto, evitando o emprego desmedido do gerúndio. Trata-se de um recurso adotado com vistas à melhor comunicação, o que resulta num discurso com uma composição estranha e incômoda para a expressão do pensamento.

\section{b) particípio}

Considerem-se expressões:

$\begin{array}{lll}F 1 \quad & \text { I } & {[\ldots] \text { com escrito da estudante" }} \\ & L_{2} \quad \text { "com a escrita da estudante" }\end{array}$

F2 I " "[...] sua exposto à televisão"

$\mathrm{L}_{2} \quad$ "[...] sua exposição à televisão"

F3 I "[...] origem dos nomes porque a maioria são um mechilhado"

$\mathrm{L}_{2} \quad$ "[...] origem dos nomes porque a maioria é um mesclado" (mistura)

$\mathrm{Na}$ primeira, [...] com escrito da estudante optou-se adequadamente pelo particípio, escrito, mas este foi usado sem a devida roupagem exigida pela nominalização que corresponde ao uso do determinante a, do feminino singular, presente no substantivo escrita. Desconsidera-se assim a nominalização apropriada ao contexto pela restrição ao uso dessa forma verbal usada na formação dos tempos compostos. 
Na segunda, [...] sua exposto à televisão correspondente à [...] sua exposição à televisão forma-se inadequadamente o substantivo na expressão sua exposto. Justifica-se tal emprego com base em duas hipóteses. A primeira considerando que, por associação a outras derivações possíveis, nominalizou-se um particípio, que ficou agramatical. Sabemos que o sistema permite essa transformação em casos como: o machucado, o salgado, o passado, incluindo o composto e, o exposto, entre outros. A inadequação do particípio nessa fala é, no entanto, atribuída à presença de um determinante no feminino em um contexto em que a nominalização é transitiva, isto é, exige um complemento: à televisão, portanto, uma estruturação virtualmente preparada para admitir somente uma derivação sufixal exposição.

Essa segunda hipótese reside na confusão substantivo/adjetivo, pois as atualizações apropriadas ao contexto seriam:

"[...] porque está exposto à televisão (adjetivo)" e

"[...] por sua exposição à televisão (substantivo)"

Na terceira,

"[...] origem dos nomes porque a maioria são um mechilado"

por

"[...] origem dos nomes porque a maioria é um mesclado (mistura)",

nominaliza-se o particípio por influência espanhola ao invés de se criar o deverbal mescla/mistura.

\section{C) Infinitivo}

Observem-se as expressões registradas nas falas que seguem:

F1 I "[...] uma idéia que pode ajudar para formar uma tipa de [...] uma aula de português bem legal."

$\mathrm{L}_{2} \quad$ "[...] uma idéia que pode ajudar na formação (criação) de um tipo de aula de português bem legal." 


\section{F2 I "Um camino para correr" \\ $\mathrm{L}_{2} \quad$ "Uma pista de corrida" \\ F3 I "[...] coisas como o devertir" \\ $\mathrm{L}_{2} \quad$ "[...] coisas como o divertimento"}

$\begin{array}{lll}\text { F4 I } & \text { "outro sistema de vivir" } \\ & \mathrm{L}_{2} \quad \text { "outro modo de vida" }\end{array}$

F5 I "eu não consegui bolsa estudar"

$L_{2} \quad$ "eu não consegui uma bolsa de estudos"

F6 I "o questión da falar"

$\mathrm{L}_{2}$ "a questão da fala (manifestação)"

F7 I "eles podem conseguir escrever"

$\mathrm{L}_{2} \quad$ "eles conseguem aprender a escrita"

F8 I "[...] coisa bem legal para ajudar com escrever"

$\mathrm{L}_{2} \quad$ "[...] coisa bem legal para ajudar (desenvolver) a escrita"

F9 I "este período de ajustar"

$\mathrm{L}_{2} \quad$ "este período de ajuste" (adaptação)

F10 I " $[\ldots]$ tem que estudar mais, tem uma de F [...] graduar de uma Escola $[\ldots] "$

$\mathrm{L}_{2} \quad$ "[...] tem de estudar mais, tem de ter uma graduação (um certificado) de Faculdade"

Em 1, optou-se pelo uso do infinitivo formar por desconhecimento do substantivo correspondente, formação, ou por incapacidade de criá-lo.

Em 2, observa-se uma dificuldade na derivação do verbo correr para o substantivo corrida., uma forma provavelmente oriunda do particípio, conforme observado anteriormente. 
Em 3, nominalizou-se o infinitivo devertir em lugar de divertimento, provavelmente por influência da língua inglesa [prep+-ing correspondente ao infinitivo em português], o que revela uma dificuldade na formação do substantivo.

Em 4, não se localiza o substantivo vida derivado de viver. Tem-se o infinitivo vivir por influência do espanhol.

Em 5, usou-se o verbo estudar no infinitivo o que acarreta a desestruturação do sintagma bolsa de estudos.

Em 6, aparece o infinitivo falar por desconhecimento do substantivo correspondente ou por incapacidade de fazer uso do processo de derivação regressiva para atualizar a palavra fala.

Em 7, por não se transformar o infinitivo escrever no substantivo escrita, ocorrem sintagmas verbais com auxiliares poder e conseguir redundantes e desnecessários. A opção aprender a escrita torna a idéia mais expressiva e natural através da nominalização do particípio no feminino em vez de seqüência de formas infinitivas.

Em 8, tem-se um registro semelhante ao anterior, em que se emprega o infinitivo escrever substituindo a forma nominalizada do particípio feminino, escrita um caso típico do uso abusivo do infinitivo. Trata-se de uma expressão diretamente transferida do Inglês para o português, formada com a terminação -ing, writing, precedida da preposição with, que foi traduzida no infinitivo por ser uma correspondência bastante freqüente [prep+-ing,] infinitivo em Português, ou por não se saber criar a nominalização do verbo escrever. Foi mais fácil fazer uso do verbo no infinitivo do que formar o substantivo através da nominalização do particípio.

Em 9, não se formou o substantivo ajuste; por derivação regressiva. Ao invés desse deverbal adotou-se mais uma vez o recurso do infinitivo.

Em 10, na falta substantivo graduação pela derivação sufixal; repetiu-se o do uso vicioso do infinitivo.

\section{d) particípio presente}

Apesar da terminologia desusada, por corresponder a uma das vertentes da bifurcação do particípio antigo em presente e passado, essa forma de particípio 
presente mantém-se viva e necessária aos discursos, motivo pelo qual ela foi aqui incluída, uma vez que pertence ainda aos casos relacionados às formas nominais.

Analisem-se:

$\begin{array}{ll}\mathrm{F} 1 \quad \mathrm{I} & \text { "Resto do Brasil é outra coisa" } \\ & \mathrm{L}_{2} \quad \text { "o restante do Brasil é outra coisa" }\end{array}$

F2 I "A gente que falam [...] da língua"

$L_{2} \quad$ "os falantes da língua"

Em 1, a derivação regressiva resto, sem o devido determinante carrega uma nuance pejorativa por assumir o lugar da formação culta restante, construída através do sufixo -nte, isto é, uma nominalização do antigo particípio presente.

O erro nesse caso caracteriza-se não mais pela presença, como se verificou com as formas nominais do gerúndio, do infinitivo e do particípio apresentadas, mas pela ausência de um substantivo mais apropriado semanticamente correspondente a essa forma do antigo particípio presente, o que chamou nossa atenção pela sua pertinência ao contexto.

A ocorrência 2, a gente que falam, também sugere a pertinência dessa forma nominal. Encontra-se nessa fala uma maneira prolixa de substituição à disponibilidade concisa e usual: falantes.

Os recursos utilizados nessas ocorrências configuram-se muitas vezes pelo uso aleatório das formas nominais, daí podermos constatar uma dificuldade na geração adequada de substantivos.

\subsubsection{Formas moninalizadas: derivação regressiva}

Nesta parte de nosso trabalho procuramos estabelecer os limites entre os conceitos de nome e verbo no que se refere ao processo de derivação regressiva, em diferentes situações contextuais.

Por serem formas não marcadas, os deverbais são reconhecidos por uma função sintática específica, exercida dentro de um determinado contexto que eles 
próprios criam para serem distinguidos e caracterizados como nomes-substantivos. Correspondem às chamadas formas nominalizadas, resultantes de uma roupagem que as destaca pela presença de determinantes.

A formação dos deverbais através de suas possíveis desinências $-a /-e /-o$ corresponde a um quase inatingível emaranhado de variáveis morfológicas, bem próximo ao que encontramos em universos paralelos e de mesma natureza: as flexões das conjugações verbais. Com vistas a essas disponibilidades reunimos as ocorrências, conforme:
F1 I "eu queria uma descansa não, mas uma coisa deferente [...]"
$\mathrm{L}_{2} \quad$ "eu não queria (dar) uma descansada não (uma parada, uma relaxada, um descanso), mas (sim) uma coisa diferente [...]"
F2 I "Aqui no USP todos os estudantes têm interessa na matéria"
$\mathrm{L}_{2} \quad$ "Aqui na USP todos os estudantes têm interesse pela matéria (em estudo, disciplina)"

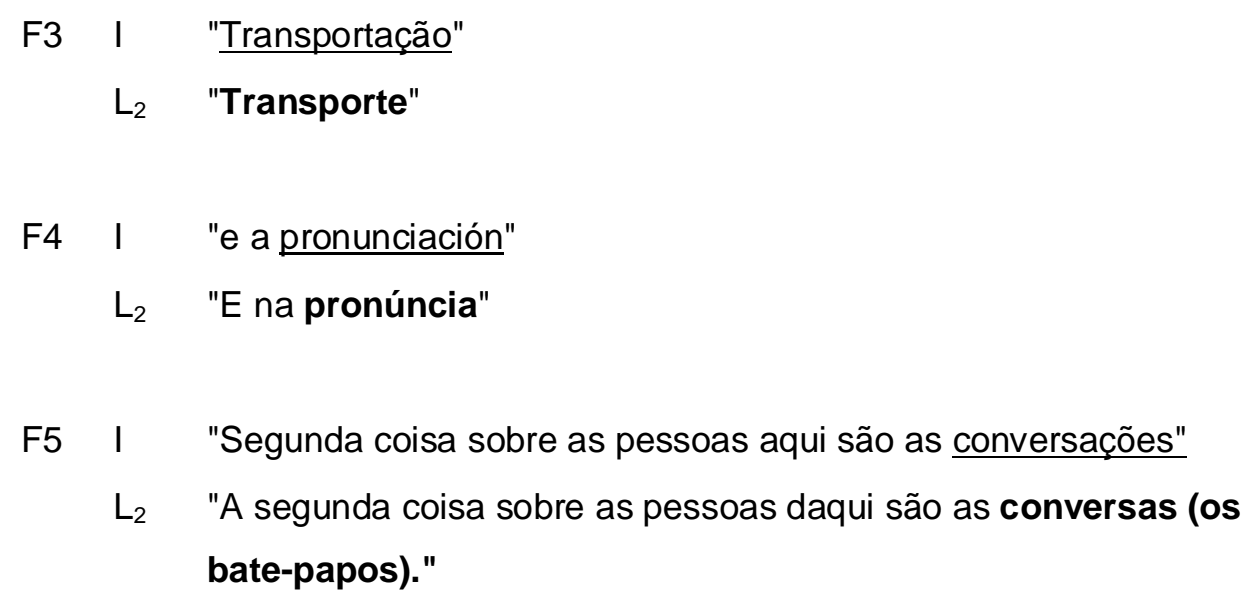

F4 I "e a pronunciación"

$\mathrm{L}_{2} \quad$ "E na pronúncia"

F5 I "Segunda coisa sobre as pessoas aqui são as conversações"

$\mathrm{L}_{2} \quad$ "A segunda coisa sobre as pessoas daqui são as conversas (os bate-papos)."

$\begin{array}{lll}\text { F6 I } & \text { "Processo de ajustamento" } \\ & \mathrm{L}_{2} \quad \text { "processo de ajuste (acordo)" }\end{array}$

$\begin{array}{ccc}\text { F7 } & \mathrm{I} & \text { "o estudamento" } \\ & \mathrm{L}_{2} \quad \text { "o estudo (análise)" }\end{array}$

F8 I "Como os cruzadas foram pra o rio Jordão e travessa - eles tinha o 


\begin{abstract}
permissão do rei trocar o nome [...]"
$\mathrm{L}_{2} \quad$ "Como as cruzadas foram para a direção do rio Jordão, na travessia eles tinham a permissão de trocar (mudar) o nome (de família) [...]"
\end{abstract}

F9 I "Não é critico"

$\mathrm{L}_{2} \quad$ "não é uma crítica"

Em 1, dada a dificuldade na caracterização do gênero do deverbal descanso encontra-se a desinência - $a$ em vez de -0 . O feminino decorreu, provavelmente, por associação a uma relaxada correspondente a uma descansada em que a terminação - da é marca de feminino das palavras no particípio.

$\mathrm{Na}$ ocorrência 2, observa-se um problema de ordem morfológica estabelecido pela escolha indevida da desinência - a em interessa por interesse. Origina-se uma confusão entre as vogais temáticas $-a,-e,-o$, características das conjugações verbais.

A palavra transportação, em 3, resulta de uma derivação sufixal em lugar da regressiva transporte. Em vez desse deverbal, aportuguesou-se transportation o que leva a inferir uma influência inglesa, reflexo da língua materna.

Temos em 4 e 5 dois casos de influência dupla: misturam-se as formas da língua materna e da língua espanhola anteriormente adquirida, respectivamente, pronunciation, pronunciación e convesation, conversación, ignorando-se o deverbal pronúncia e conversas do português, resultante do processo de derivação regressiva. Consideramos que a palavra conversação seria mais adequada para designar a pratica oral nos cursos de línguas.

As ocorrências 6 e 7 apresentam a mesma inadequação: uma derivação sufixal através de -mento em ajustamento e estudamento em substituição aos respectivos deverbais correspondentes: ajuste e estudo. Nessas nominalizações improcedentes nota-se uma única diferença no que se refere aos morfemas -e e -o dos respectivos deverbais substituídos por palavras derivadas às quais se atrelou 0 sufixo - mento.

Em 8, contrariamente ao que se verificou anteriormente, a atualização por travesia, semanticamente improcedente, se origina no mecanismo encontrado nos deverbais como travessar/travessa. Registra-se a redução do ditongo -ia por 
associação com palavras como promessa, pressa ou com a própria palavra travessa (utensílio doméstico) ou ainda por desconhecimento do sufixo -ia.

Nota-se em 9, uma derivação regressiva anômala, o uso inadequado da primeira pessoa do singular do verbo criticar em substituição ao deverbal crítica em que a desinência -o substitui o morfema - $a$, tendo sido eliminado o determinante. Queremos crer ter havido uma associação com ganhar/ganho, abraçar/abraço, entre outras.

Com base nessas ocorrências evidencia-se a dificuldade dos estrangeiros na distinção de transformações como as dos deverbais em -a, a exemplo de falarl a fala, comprarla compra; em -o, do tipo estudar/o estudo, descansar/o descanso e em -e, como enfeitar/o enfeite, desgastar/o desgaste, transportar/o transporte. Daí a necessidade do condicionamento das nominalizações mais freqüentes e necessárias a uma satisfatória comunicação em português.

Ainda merecem destaque as criações especiais relativas aos deverbais:

F1 I "[...] eu vou fazer, eu deve fazer uma procuração muitos detalhes com professor porque [...]"

$\mathrm{L}_{2} \quad$ "[...] eu preciso fazer uma busca (uma procura) bem detalhada de professor porque [...]"

F2 I "Você precisa um esperança mui grande os coisas da alfândega. Eu sinto nervioso."

$\mathrm{L}_{2} \quad$ A gente precisa (nós precisamos) de uma longa espera (esperar muito) para obter nossos pertences (bens pessoais ainda não liberados). Eu fiquei irritada.

F3 I "Como eu tengo dentro mia cabeça tanta preocupas porque eu salto (nas práticas da equitação)."

$\mathrm{L}_{2} \quad$ "Como eu tenho (trago) na minha mente tantas preocupações [tanta (muita) preocupação] porque eu salto (nas práticas da equitação)."

F4 I "Fuê uma coisa difícil [...] um cobra todos lados se eu conseguio um bolsa."

$\mathrm{L}_{2} \quad$ "Foi uma coisa difícil. Era uma cobrança de todos os lados para (eu conseguir) uma bolsa." 
F5 I "Existe uma precisa do mudar os coisas"

$\mathrm{L}_{2} \quad$ "Existe uma necessidade de mudas as coisas."

F6 I "Quando uma pessoa de [...] é possível ter uma concorda verbal [...]"

$\mathrm{L}_{2} \quad$ "Quando uma pessoa é de (tem) responsabilidade é possível ter com ela um acordo verbal [...]"

F7 I "Gastam muito dinheiro a administração deste tipo de arranja."

$\mathrm{L}_{2} \quad$ "Gasta muito dinheiro a administração deste tipo de organização (sistema de governo)."

F8 I " o trocô lais de Ferdinão [...]"

$\mathrm{L}_{2} \quad$ "a troca (mudança) de leis do Fernando (Henrique) [...]"

F9 I "Beleza natural [...], aqui em Brasil, que você tem [...] agradesco thes deram [...]"

$\mathrm{L}_{2} \quad$ "Beleza natural [...] aqui no Brasil, que vocês têm [...] um agradecimento (graça) que lhes deram"

F10 I "[...] mas a maioria dos estrangeiros uma dividio que cinqüenta por cento inglês, cinqüenta por cento português - uma conversa pouco estranha '[...]"

$\mathrm{L}_{2} \quad$ "[...] pois a maioria dos estrangeiros apresenta uma mistura (uma divisão na fala): cinqüenta por cento inglês, cinqüenta por cento português [...]"

Nas duas primeiras ocorrências criam-se palavras pela derivação sufixal, procuração e esperança que exibem desvios morfossemânticos em total desencontro com os deverbais apropriados, respectivamente busca e espera disponíveis em português. Acrescentaram-se sufixos aleatórios -ção e -ança gerando palavras com sentidos totalmente diferentes daqueles exigidos pelo contexto.

Em 3, 4, 5, 6 e 7, encontram-se formações inadvertidas de deverbais, verdadeiras inovações, que desrespeitam as referências ora morfológicas, como em 
preocupas, precisa, concorda e arranja; ora semânticas, como em cobra, nitidamente perceptíveis nas correspondência com $\mathrm{L}_{2}$ : preocupações, necessidade, acordo, organização e cobrança.

Registra-se em 8 um caso merecedor de comentário dada a originalidade da forma escolhida pelo falante, o trocô que reflete uma tentativa agramatical de gerar uma mudança de classe da forma verbal trocou para substantivo mediante a presença do determinante $o$. Acreditamos que essa substantivação do pretérito perfeito do indicativo do verbo trocar para substituir a troca se justifica por uma eventual mistura com a sonoridade (seqüência fonética) da forma verbal de $3^{\text {a }}$ pessoa do singular, trocou ou uma menos provável analogia com a palavra troco (devolução, moeda). Uma possibilidade bem mais convincente é a de se ter recorrido à nominalização da forma verbal trocou para significar troca no passado.

Em 9, observa-se a presença de agradesco correspondente a agradeço em $L_{2}$, por influência da língua anteriormente adquirida, o espanhol. Tem-se uma generalização automática e improcedente voltada ao mecanismo adotado em outras derivações regressivas a exemplo de cantar/canto em lugar do substantivo agradecimento, resultante de uma apropriada derivação sufixal.

A fala 10, diferentemente dos errors anteriormente considerados, exibe um mistake, dividio, ocasionado por um descuido que sugere um condicionamento motivado, possivelmente, pela existência de palavras como: exílio e convívio, entre outras comuns no uso cotidiano, em vez da adequada derivação sufixal, divisão.

Ainda a respeito da criação de nomes-substantivos observem-se as relações evidenciadas no quadro ${ }^{34}$ :

\begin{tabular}{|l|l|l|}
\hline VERBO & DEVERBAL & $\begin{array}{l}\text { SUBSTANTIVO } \\
\text { (derivação sufixal) }\end{array}$ \\
\hline Estudar & o estudo & ${ }^{*}$ estudamento \\
\hline Preocupar & ${ }^{*}$ preocupas & preocupação \\
\hline Conversar & a conversa & ${ }^{*}$ conversações \\
\hline Pronunciar & a pronúncia & ${ }^{*}$ pronunciamento \\
\hline Cobrar & ${ }^{*}$ um cobra & cobrança \\
\hline
\end{tabular}

${ }^{34}$ * O asterisco corresponde aos erros (errors) - equívocos cometidos pelos entrevistados. 


\begin{tabular}{|l|l|l|}
\hline Agradecer & *o agradeço (a graça) & agradecimento \\
\hline Procurar & a procura & *procuração \\
\hline Arranjar & *arranja (o arranjo) & Organização \\
\hline Esperar & a espera & ${ }^{*}$ esperança \\
\hline Concordar & *a concorda (o acordo) & - \\
\hline Dividir & *uma dividio (uma mistura) & Divisão \\
\hline Trocar & ${ }^{*}$ o trocou (a troca) & - \\
\hline Precisar & * uma precisa & precisão (necessidade) \\
\hline mudar & *o muda & Mudança \\
\hline Criticar & $\left\{\begin{array}{cc}\text { o crítico (concreto) } \\
\text { a crítica (abstrato) }\end{array}\right.$ & - \\
\hline
\end{tabular}

Quadro 4 - Relações verbo (infinitivo) e deverbais

Nesse quadro concentram-se as dificuldades - de acordo com o registro encontrado nas falas - que comprometem a comunicação; ele expõe com mais evidência as relações entre as formas verbais originais e as nominalizadas na criação dos nomes-substantivos.

Esses mecanismos de nominalização improcedentes decorrem de automatismos de criações lexicais inaceitáveis, geradas entre a forma verbal e a nominal latente.

\subsubsection{Falhas vocabulares}

Além dos problemas relativos às formas nominais e nominalizadas, outros problemas de comunicação se revelam na fala dos entrevistados.

Atente-se para:

F1 I "Eu acho que eu tengo um pouco de [...] britânica"

$\mathrm{L}_{2} \quad$ "Eu acho que eu tenho um pouco de ascendência (sangue, origem) britânica" 
$\mathrm{Na}$ falta de conhecimento e localização das palavras adequadas, a dificuldade na seleção lexical do substantivo torna-se bem evidente, pois as frases são interrompidas, apresentando lacunas semelhantes à registrada, na interlíngua, cujo preenchimento deve ser inferido pelo contexto. As possíveis sugestões ascendência/sangue/origem aparecem na $\mathrm{L}_{2}$ correspondente à respectiva fala. Esses casos serão detalhados a seguir.

\subsubsection{Ausência de substantivos}

Outras dificuldades na localização dos substantivos:
F1 I "[...] ter boa [...] de ser muito saudável"
$\mathrm{L}_{2} \quad$ "[...] Ter boa saúde"
$\begin{array}{lll}\text { F2 } & \text { I } & \text { "Sinto falta da }[\ldots], \text { de ser fluente }[\ldots] " \\ & L_{2} \quad \text { "Sinto falta da fluência, de ser fluente }[\ldots] "\end{array}$

F3 I " " [...] é uma país tão diverso Quanto interessante e fica culturalmente."

$\mathrm{L}_{2} \quad$ "[...] e fica importante culturalmente."

ou "[...] e fica importante para a cultura.

F4 I "[...] o brasileiro dão mais [...] valoriza mais [...]"

$\mathrm{L}_{2} \quad$ " os brasileiros dão mais valor, valorizam mais [...]"

F5 I "eu sei que a meu [...] meliora"

$L_{2} \quad$ " eu sei que o meu estado de espírito (humor) vai melhorar"

$\begin{array}{ccc}\text { F6 } & \text { I } & \text { "ele (o estudante) está tentando expressar seus [...];" } \\ & \mathrm{L}_{2} \quad \text { " Expressar seus pensamentos;" }\end{array}$

F7 I "e tem sus limitações de ( ...);"

$\mathrm{L}_{2} \quad$ "suas limitações de língua;" 
F8 I "sus limitações de [...] culturais"

$\mathrm{L}_{2} \quad$ "suas limitações de referências (abordagens) culturais"

F9 I " [...] tarefa que pode ajudar [...] com a língua"

$\mathrm{L}_{2} \quad$ "[...] ajudar na aprendizagem (estudo) da língua"

F10 I "Quando uma pessoa de [...] é possível ter uma concorda verbal [...]"

$\mathrm{L}_{2} \quad$ "Quando uma pessoa é de (tem) responsabilidade, é possível fazer com ela um acordo verbal [...]"

F11 l "não temos [...] (em Inglês)"

$\mathrm{L}_{2} \quad$ "não temos gênero (em Inglês)"

F12 I "essas coisas quando $\underline{\text { cad }}[\ldots]$ como o tempo [...] existem dúvida, não existem dúvida [...]"

$L_{2} \quad$ "essas coisas como formas verbais diferentes (para cada tempo e modo);"

F13 I "as coisas gramáticas"

$\mathrm{L}_{2} \quad$ "os itens (tópicos) gramaticais"

F14 I " $[. .$.$] acham que [...] fica igual que Espanhol "$

$\mathrm{L}_{2} \quad$ "[...] acham que Português é igual ao Espanhol"

F15 I "extrapolar um pouco na entrevista sobre as diferências entre São Paulo $[\ldots]$;"

L2 "Estender-se um pouco na entrevista sobre as diferenças entre São Paulo e outras lugares (do mundo) [...];"

F16 । " "[...] sua nivel de [...], sua curiosidade;"

$\mathrm{L}_{2} \quad$ "[...] seu nível de interesse, sua curiosidade;"

F17 I "os americanos são muitos ligados a [...] ao educación mesmo"

$\mathrm{L}_{2} \quad$ "[...] os americanos são muito mais ligados à cultura (ao conhecimento) mesmo" 
Uma breve interrupção na primeira fala, devida à dificuldade em localizar o substantivo: saúde, preenche-se na expressão ter boa saúde, conforme $L_{2}$.

Caso semelhante observa-se na segunda fala em que se supre a lacuna da palavra fluência por de ser fluente, parafraseando-se o substantivo apropriado.

$\mathrm{Na}$ fala 3, trunca-se exabruptamente o pensamento pela expressão vaga fica culturalmente, em que se usa um advérbio para suprir a falta do substantivo cultura.

Temos em 4 o uso alternativo de um verbo valoriza para compensar a dificuldade de acesso ao substantivo valor na expressão dar valor .

Em 5, a interrupção do pensamento por falta de uma expressão ou substantivo, compatível com a intenção do falante ocasionou o preenchimento da lacuna com a expressão da $L_{2}$, estado de espírito ("humor"), por inferência, conforme já observado.

Nos registros de 6,7 e 8 mantém-se o mesmo problema comentado em 5, devido a deficiências de vocabulário, que impedem a atualização adequada do pensamento pelo uso de substantivos, tais como os inferidos em $L_{2}$ na seqüência: pensamentos, língua, referências ("abordagens").

Problemas mais abrangentes apresentam-se nas ocorrências seguintes ( $9 \mathrm{e}$ 10 ) consideradas semelhantes às anteriores pela maneira exabrupta na interrupção das falas, bloqueando a informação. Conforme se observa em L2 foi indispensável o preenchimento das respectivas lacunas com os substantivos aprendizagem e responsabilidade para que se recuperasse a informação truncada, pelas tão mencionadas razões: inacessibilidades ao substantivo apropriado.

Como se observa a presença de lacunas revela-se muito comum nas falas. No registro 11, verifica-se novamente a ausência do substantivo. A palavra gênero não ocorreu para que o falante completasse seu pensamento, como mostram as reticências, avenando-se a possibilidade de uso da palavra sexo. Trata-se de um mistake a ser comprovado adiante.

$\mathrm{Na}$ fala 12, repete-se a insuficiência de vocabulário que dificultou a emissão de uma expressão da terminologia aplicada à morfologia: formas verbais diferentes.

Em 13, outro tipo de lacuna evidencia-se pelo uso da palavra genérica e vaga coisa, uma forma alternativa de substituir o vocábulo desejado. Muitas vezes usa-se a palavra coisa para preencher uma deficiência de vocabulário, confirmada pelas ausências, o que acaba caracterizando uma dificuldade na escolha e, 
conseqüentemente, um desconhecimento dos substantivos adequados às diferentes situações de comunicação.

As ocorrências 14 e 15 apresentam um outro tipo de construção relacionada às ausências.

Observe-se a fala 14, ao se procurar estabelecer uma comparação, omite-se o termo referente, português, truncando-se a expressão e na fala 15, ainda atrelado aos espaços vazios a ausência do segundo termo da comparação, outros lugares trunca abruptamente a idéia, tornado-a incompreensível.

As lacunas preenchidas respectivamente por Português e outros lugares elucidam em $L_{2}$ a criação anômala dessas comparações.

Na ocorrência 16, não se localiza o deverbal adequado, interesse, retomandose a idéia, pelo uso do substantivo curiosidade.

Encerrando nossa investigação sobre as falhas e as ausências lexicais, abordaremos a fala 17 devido à sua situação significativa: uma mistura da língua materna quanto ao significado, com a língua anteriormente adquirida, quanto à forma. Tem-se a atualização educación do espanhol com a aquisição do sentido de "cultura" em que é bem perceptível a influência inglesa do education, como confirma o contexto. A inserção de muito mais em $L_{2}$ corresponde ao morfema de plural $-s$ erroneamente colocado em muitos na interlíngua.

Como se verificou, os entrevistados, algumas vezes, tentam suprir as necessidades de comunicação com expressões formadas por adjetivo; outras vezes, por verbos correspondentes aos vocábulos adequados, que se identificam mais precisamente com a classe dos substantivos; é grande, no entanto, o registro de lacunas, em que as palavras precisam necessariamente ser inferidas pelo contexto.

Dando seqüência ao levantamento das dificuldades reveladas pelas falas, corpus deste trabalho, passamos aos problemas relativos aos determinantes.

\subsubsection{Deteminante-artigo}

Este item destina-se à observação do comportamento dos determinantes e suas implicações textuais sintático-semânticas, especificamente com a interpretação das mensagens. 
Agrupemos as ocorrências:

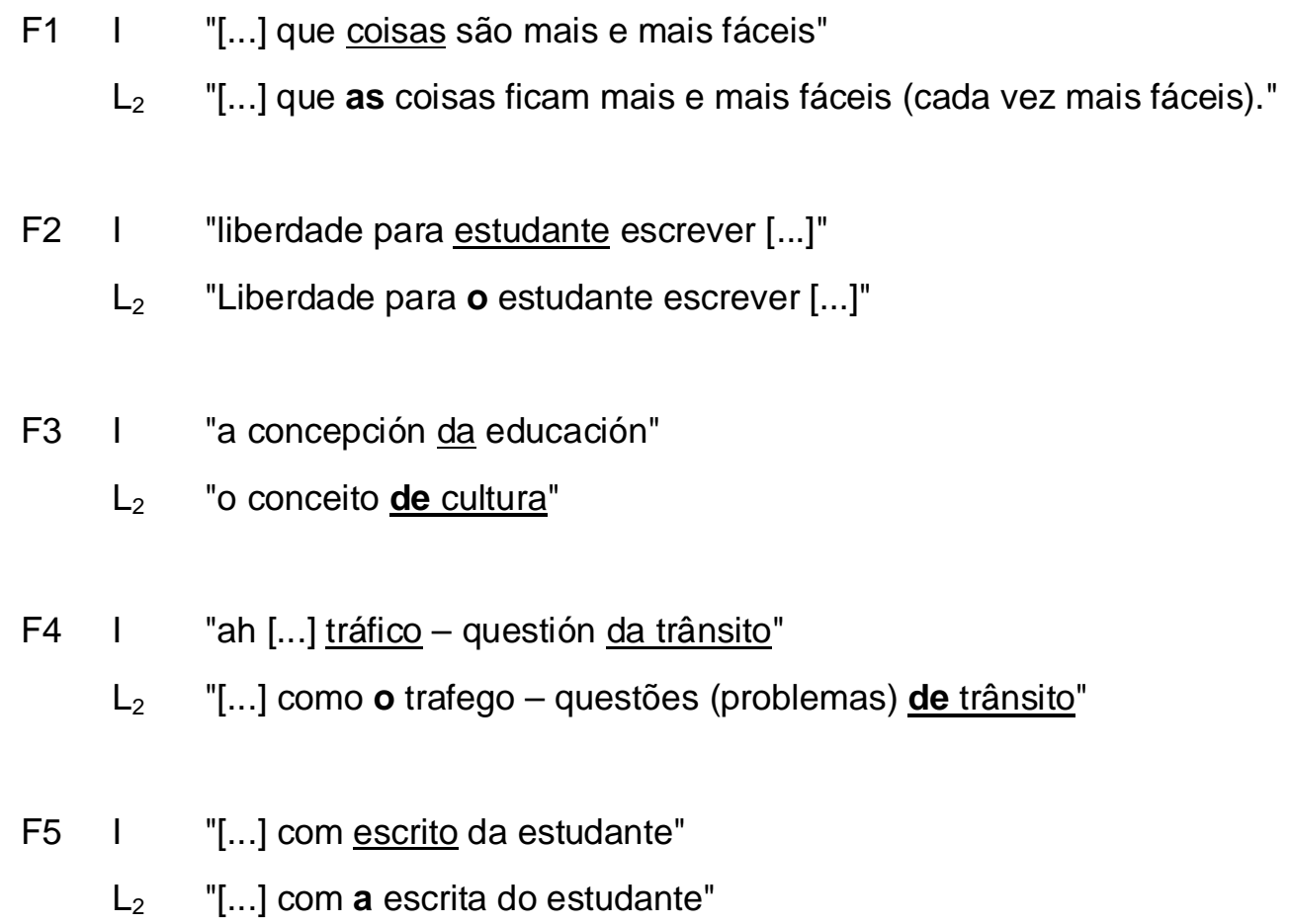

Conforme mencionado, a palavra coisas em si já é vaga, e a ausência do artigo (determinante), na interlíngua 1, torna-a genérica, portanto, ainda mais incompreensível, chegando até a criar uma redundância. A presença do artigo as em $\mathrm{L}_{2}$ vem dar maior adequação e reforço semântico a esse substantivo que , no texto, adquire sentido de "obstáculos", "problemas".

$\mathrm{Na}$ fala 2, utilizou-se uma generalização, estudante, mas sem artigo e com o substantivo no singular. Essa ausência do artigo acontece em Inglês, mas em situação diversa: quando estivermos nos referindo ao artigo indefinido e com o substantivo usado no plural; não deverá, portanto, ser caracterizada como transferência. Em português, a presença do artigo, nesse caso, vem colaborar para uma compreensão mais precisa do pensamento do falante.

O uso do determinante artigo é uma dificuldade que se justifica pelo fato de a língua portuguesa usar também o artigo definido o com sentido genérico, o que traz grandes dúvidas para falante estrangeiro: 0 estudante, em português, pode significar "os estudantes" de maneira geral - um uso que corresponde à figura de linguagem sinédoque (a parte pelo todo). Em $O$ estudante brasileiro trabalha durante $o$ dia $e$ 
estuda à noite o componente o estudante se estende ao plural passando a significar a totalidade dos estudantes.

Note-se na ocorrência 3, além do problema da influência do inglês, a presença infundada do artigo a na interlíngua em da educación que passa a ser interpretada como cultura de maneira específica, desviando-se da verdadeira intenção do falante.

Em tráfico, na fala 4, a ausência do artigo generaliza a idéia e a presença do artigo a no modificador (da trânsito) do sintagma question da trânsito especifica-o desnecessariamente, o que não se verifica em $L_{2}$.

Em 5, observa-se o uso do particípio escrito, solto na estrutura da frase, sem a devida caracterização nominal para designar uma escrita especifica, a escrita do estudante.

Ainda sobre o uso de determinante artigo, observemos:

F1 I "[...] com escrito da estudante"

$\mathrm{L}_{2} \quad$ "[...] com a escrita do estudante"

F2 I "[...] aprender a Português"

$\mathrm{L}_{2} \quad$ "[...] aprender Português (a língua portuguesa / o idioma português)"

F3 I "[...] falando da cosa totalmente diferente"

$L_{2} \quad$ "[...] falando de uma coisa totalmente diferente"

F4 I " [...] a gente não tinha tantas problemas da saúde se não fora - fosse a poluição."

$L_{2} \quad$ "[...] a gente não teria tantos problemas de saúde se não fosse a poluição."

F5 I "Fiquei doente da saudade e da lástima"

$\mathrm{L}_{2} \quad$ "fiquei doente de saudade e de dor

F6 I "Expectativa da vida"

$\mathrm{L}_{2} \quad$ "com expectativa de vida" 


\section{F7 I "Meninos da rua (que estão na rua)" \\ $\mathrm{L}_{2} \quad$ "Meninos de rua (abandonados na rua $\rightarrow$ pivetes)" \\ F8 I "[...] ajudaram com o coisa da cavalo" \\ $\mathrm{L}_{2} \quad$ "[...] ajudaram com essa coisa de cavalo" \\ F9 I "[...] não lembra di a próxima" \\ $\mathrm{L}_{2} \quad$ "[...] não se lembra do próximo"}

Na fala 1, em da estudante, usou-se a desinência a do feminino em vez de 0 do genérico masculino, um morfema já comentado por sua possibilidade de estabelecer a generalização do substantivo na $\mathrm{L}_{2}$.

Considera-se, na ocorrência 2, o uso desnecessário do artigo a, antecedendo o nome da disciplina Português, em vez do 0 do genérico masculino, subentendendo-se a palavra idioma. Propõe-se como uma primeira alternativa para eliminar o erro a retirada do artigo, deixando Português sem determinante por funcionar como complemento do verbo aprender e corresponder ao nome de uma disciplina Português, Inglês, Geografia, entre outras. Nesse caso também se poderia supor que o falante não soubesse diferenciar em $L_{2}$, o sufixo -ês do masculino de esa do feminino, optando pelo artigo a para uma eventual concordância com o feminino da palavra língua subentendida no contexto. Essas possibilidades, entretanto, não minimizam a reconhecida falha na presença do artigo; somente somam razões que possam justificá-la.

Verifica-se, na ocorrência 3, o uso também indevido do artigo definido a em lugar do indefinido uma, antecedendo a palavra cosa. Nesse caso, o artigo a está em desacordo com a indeterminação que se acha nitidamente estabelecida na expressão.

Temos, registrada na fala 4, a expressão problemas da saúde em que a presença do artigo a em da saúde altera o significado de uma informação de caráter genérico.

Além dessa fala, outras variáveis frasais continuam descaracterizando a generalização pela presença do artigo conforme ocorrências de 5 a 12. 
Em 5, em da saudade e da lástima não há a necessidade do artigo — os modificadores de saudade e de dor fazem parte de expressões peculiares que portam em si a idéia de generalização.

$\mathrm{Na}$ fala 6, 7 e 8 apresentam-se casos semelhantes ao anteriormente visto, quanto aos modificadores, um adjunto adnominal preposicionado, respectivamente, da vida, da rua e dạ cavalo . A presença do artigo a impede a generalização implícita nos modificadores; conseqüentemente, altera-Ihes o sentido em desrespeito total à intenção dos falantes.

Esses desencontros sintático-semânticos ainda se repetem em registros especiais, como no caso da fala 9, em que se usou a forma feminina a próxima, flexionando-se o genérico, em detrimento da forma masculina consagrada, 0 próximo, que se destina a representá-lo.

Acrescentamos a seguir quatro falas em que se repete a prática já instalada do uso indevido do artigo:

F1 I "[...] eu tava cruzando (o rio Pinheiros) e da repente, né? Por que é? Puxa! Foi um vaca."

$\mathrm{L}_{2} \quad$ "[...] eu estava cruzando (o rio Pinheiros) e de repente, né? Que é isso? Puxa! Era uma vaca."

F2 I "[...] se eu tinha o tempo, eu gostaria escrever uma livra [...]"

$L_{2} \quad$ "[...] se eu tivesse tempo, eu iria escrever um livro [...]"

F3 I " "...] Quando eu tenho a oportunidade, eu viajar para o litoral."

$L_{2} \quad$ "[...] Quando eu tenho oportunidade, eu viajo para o litoral."

F4 I "Aqui em esta sala a janela é igual que qualquer outra janela de edifício."

$L_{2} \quad$ "Aqui nesta sala a janela é igual a qualquer outra janela do edifício."

$\mathrm{Na}$ fala 1, na tentativa de especificar o imprevisto, criou-se uma forma estranha da repente para a locução adverbial cristalizada de repente, desrespeitando-se a norma gramatical estabelecida. Nos segundo e terceiro casos, a inadequação do uso do artigo, respectivamente, em $\underline{o}$ tempo e em $\underline{a}$ oportunidade 
se deve ao fato de as palavras tempo e oportunidade caracterizarem idéias indeterminadas que dispensam o uso do artigo. Observa-se, entretanto, no quarto e último caso uma situação contrária às anteriores: a presença do artigo o em do edifício é necessária e se justifica por se tratar, de uma referência a um edifício específico.

Conclui-se pelo exposto que o uso improcedente do determinante artigo se caracteriza tanto pela sua ausência quanto pela sua presença desnecessária ou indevida em função das normas gramaticalmente estabelecidas. Em ambos os casos observou-se que a generalização ou a particularização decorrente do emprego impróprio do artigo ocasionam problemas por dificultarem a compreensão das mensagens emitidas pelos entrevistados.

\subsubsection{Contaminação semântica}

A exposição que faremos a seguir compreende registros que mostram uma tendência mais voltada aos mistakes, que exigem um discernimento bastante equilibrado a respeito das nuances semânticas inferidas em nossos mecanismos investigativos.

O critério adotado para a ordenação das estruturas consistiu em estabelecer relações de significação entre interlíngua e $\mathrm{L}_{2}$, conforme vimos procedendo neste trabalho, sem perder de vista acepções parassinomímicas, geradas pelas funções mais específicas de palavras e expressões.

Tendo em vista o volume e a variedade do material elencado, optamos por organizá-lo em vários conjuntos de referências semânticas, reconhecidas muitas vezes, mas não necessariamente como sinonímia, as quais exibem uma reunião de palavras e expressões em contextos que as distinguem por uma maior ou menor aproximação sêmica. ${ }^{35}$ Com base nesse fato a série apresentada se encontra

\footnotetext{
${ }^{35}$ GAUGER, H. M. (1918 apud GECKELER,1976) "Sinônimos son palabras que tienen significados semejantes y sinonomidad es la relación de semejanza y diversidad existente entre ellos."e Müller, (1965) "Entendemos por sinônimo una palabra que puede estar em lugar de outra en un detrminado contexto a pesar de ciertos matizes de contenido y estilísticos, es decir, que puede ser sustituída por esa outra. Esta possibilidad de sustituición no existe sin embargo, respecto a la identidad total del contenido, sino solo respecto a un punto determinado del texto."
} 
dividida em dois grupos, $A$ e B, que monitorados pela ênfase na contextualização da fala, pudessem colaborar com nossas análises. Trataremos desses grupos, respectivamente, por relações semânticas próximas e remotas.

3.1.9.1 Grupo A: relações semânticas próximas

No Grupo A, encontram-se casos de dificuldades que puderam ser facilmente inferidas pela aproximação semântica entre o sentido das palavras.

Observe-se o conjunto:

$\begin{array}{lll}\text { F1 } & \text { I } & \text { "Grupos de comida" } \\ & \text { L2 } & \text { "tipos (espécies) de comida" } \\ \text { F2 } & \text { I } & \text { "[...] os } \underline{\text { sociedades" }} \\ & \mathrm{L}_{2} & \text { "[...] os povos (as culturas)" } \\ \text { F3 } & \mathrm{I} & \text { "Uma desejo" } \\ & \mathrm{L}_{2} & \text { "uma vontade (força de vontade) }\end{array}$

A correspondência encontrada em 1, para grupos de comida mostra uma impropriedade na escolha lexical da expressão adequadamente substituída em $L_{2}$ por tipos de comida ou grupos de alimentos.

$\mathrm{Na}$ ocorrência 2,a palavra sociedades foge ligeiramente à caracterização lexical mais indicada, conforme $\mathrm{L}_{2}$. $\mathrm{O}$ artigo 0 , precedendo sociedades (no plural) já é revelador da inadequação que atribuímos à falta de automatização de palavras básicas.

Na terceira ocorrência, o uso do feminino no artigo sugere a busca e emprego da palavra vontade.

Nas correspondências deste segundo agrupamento temos:

\footnotetext{
F1 I "a cultura americana vai fazer"

$\mathrm{L}_{2} \quad$ "o povo americano (a sociedade americana) vai fazer"
} 
F2 I "a métoda de dirigir"

$\mathrm{L}_{2} \quad$ "a maneira (o modo) de dirigir"

$\begin{array}{lll}\text { F3 I } & \text { "Regras de tráfico" } \\ & \mathrm{L}_{2} \quad \text { "Normas de trânsito (trafego)" }\end{array}$

F4 I "é verdademente uma entropia nas ruas"

$\mathrm{L}_{2} \quad$ é, na verdade, um congestionamento (entupimento) nas ruas

$\begin{array}{lll}\text { F5 I } & \text { "Sua estilo da falar" } \\ & \mathrm{L}_{2} \quad \text { "sua capacidade (modo) de expressão" }\end{array}$

A cultura americana, em 1, de acordo com o contexto em que ocorre a fala, pede um substantivo concreto, o povo, e não o abstrato cultura usada em emprego metonímico.

Em 2, a métoda, palavra atualizada pelo falante, no gênero feminino, provavelmente por associação com o artigo a de maneira revela incapacidade na localização de uma forma mais natural de expressão, como se vê na $L_{2}$.

Em 3, nota-se a confusão de tráfico por tráfego, formas divergentes com significados distintos. A inadequação lexical ainda se estende, pois o usual seria normas de trânsito. Queremos crer que haja aí um erro de conceitos com abrangência sociológica já verificado com regra / padrão / norna / cultura / povo / sociedade.

Entropia, termo técnico presente em 4, como se fosse uma forma de uso corrente, é aceitável em $\mathrm{L}_{2}$ por estar associado a entropia (reviravolta), na área de oftalmologia.

Em 5, estilo aplicado ao falar restringe-se apenas a um uso menos freqüente, como se verifica em $L_{2}$.

O terceiro conjunto compreende: 


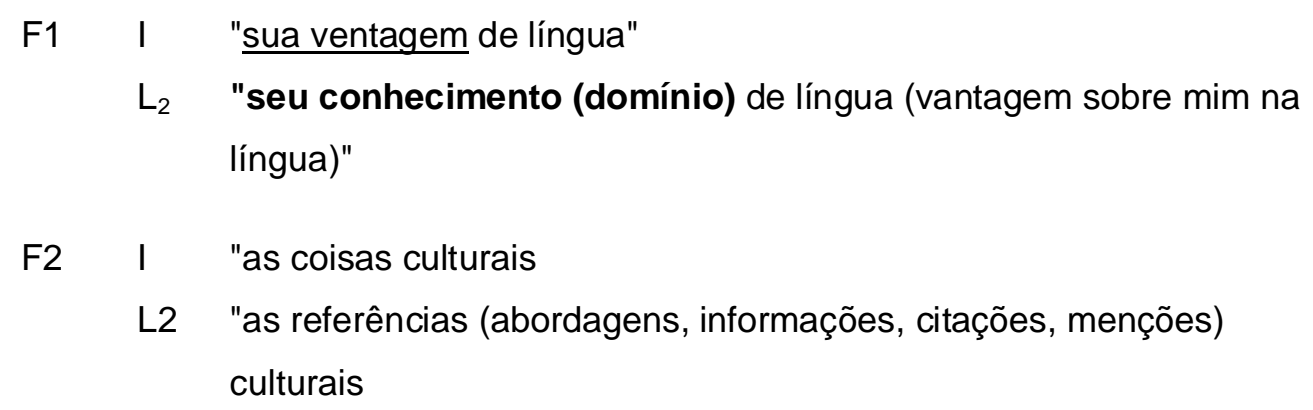

F3 I " "[...] nossos sujeitos não têm sexo."

L2 "[...] nossos substantivos não têm gênero."

F4 I "essas coisas como o tempo (verbal)"

L2 "Essas coisas como o modo (verbal)"

$\begin{array}{lll}\text { F5 } & \text { I } & \text { "[...] qual hora da dia é melhor" } \\ & \text { L2 } & \text { "[...] qual a melhor hora do dia/período do dia (horário)" }\end{array}$

$\begin{array}{lll}\text { F6 } & \mathrm{I} & \text { "os preconcepções sobre o Brasil" } \\ & \mathrm{L}_{2} \quad \text { "os preconceitos sobre o Brasil" }\end{array}$

F7 I "Este fato de facilidade"

$\mathrm{L}_{2} \quad$ "Este fator "facilidade" (esta questão de facilidade)"

No primeiro caso ocorre simplesmente uma inadequação do núcleo do sintagma nominal ventagem em vez de conhecimento, domínio. No segundo, a palavra coisa, empregada por desconhecimento de uma mais apropriada, adquire função vicária no texto. No terceiro, encontram-se, respectivamente, a palavra sujeitos em lugar de substantivos e sexo no de gênero. Ocorre, nesse caso, uma confusão terminológica envolvendo a nomenclatura da sintaxe e da morfologia. A palavra gênero pode representar tanto um sexo virtual, como em o lápis, quanto um sexo real, como em um menino. Na quarta ocorrência, nota-se outra inadequação terminológica, confunde-se tempo com modo verbal. No quinto caso, hora do dia corresponde a horário que substitui o referido sintagma. Na sexta atualização, atribuímos a palavra preconcepções a uma tentativa de formação da palavra preconceito; ao se traduzir para o português (pre) conceptus, erroneamente usou-se 
concepções em substituição a conceitos. Já, no sétimo caso, atribuímos a presença da palavra fato a uma relação morfológica, mas não semântica com a palavra fator.

No próximo grupo elencamos:

\begin{tabular}{|c|c|c|}
\hline $\mathrm{F} 1$ & I & "um coragem para aprender" \\
\hline & $\mathrm{L}_{2}$ & "Uma vontade de aprender" \\
\hline $\mathrm{F} 2$ & I & "nenhum forma de tiempo" \\
\hline & $\mathrm{L}_{2}$ & "Nenhuma parcela (período) de tempo" \\
\hline F3 & I & "fora da sua identidade" \\
\hline & $\mathrm{L}_{2}$ & "fora de seu juízo perfeito" \\
\hline $\mathrm{F} 4$ & I & "[...] tem que tomar cuidado, juízo [...]" \\
\hline & $\mathrm{L}_{2}$ & "[...] tem de tomar cuidado, ter responsabilidade (atenção) [...]" \\
\hline F5 & I & "[...], mas como estudos" \\
\hline & $\mathrm{L}_{2}$ & "[...], mas como cultura (conhecimento)" \\
\hline F6 & I & "[...] essas duas líricas só" \\
\hline & $\mathrm{L}_{2}$ & "[...] essas duas palavras só" \\
\hline F7 & 1 & "(um canción) [...] que tem um lírico super-gracinha [...]" \\
\hline & $\mathrm{L}_{2}$ & "(uma canção) [...] que tem uma letra super-gracinha [...]" \\
\hline
\end{tabular}

Nestas ocorrências, observa-se primeiramente 0 uso indevido da palavra coragem, que tem sentido de "vontade ávida", para indicar "estímulo", "vontade" ou "necessidade". No segundo caso, devido à semelhança semântica, cria-se uma expressão imprópria, acentuada na palavra forma para representar a idéia de "pouco tempo". Em fora de sua identidade e tomar cuidado, juízo, casos 3 e 4, a falha percebida na caracterização dos estados emocional e psíquico, graças à existência de semas comuns, se deve ao fato de a expressão pretender substituir, respectivamente juízo perfeito e ter responsabilidade; nesta aliam-se condições morais às emocionais. No caso 5, o uso de uma palavra paralela não atingiu o nível semântico desejado. É uma metonímia: usou a causa estudos pela conseqüência cultura. Nos itens 6 e 7, ocorrem as palavras líricas / lírico. Na primeira menção por 
influência de lyrics, do inglês, criou-se o substantivo líricas, descaracterizando-o semanticamente, para substituir a palavra versos, que não ocorreu ao entrevistado no momento da fala. Na segunda, ainda por essa mesma influência do inglês, notase uma nominalização imprópria, um lírico, pela transferência para o português do significado de "letra de música" encontrado na língua materna do falante.

Considerando a interlíngua e a $L_{2}$ das ocorrências selecionadas para nossos comentários, verificamos a presença de mistakes pela inadequação da escolha lexical, apesar da existência de uma constatada relação sêmica entre as palavras a qual facilitou a inferência da palavra mais pertinente ao texto.

3.1.9.2 Grupo B: relações sêmicas remotas

No Grupo B, devido a uma associação semântica remota, as dificuldades exigiram esforço para que se reconhecesse o sentido pretendido pelo falante.

Considerem-se as expressões:

$\begin{array}{lll}\text { F1 } & \mathrm{I} & \text { "Indentidade nacional" } \\ & \mathrm{L}_{2} & \text { "Independência política" }\end{array}$

F2 I "Fenômeno humano"

$\mathrm{L}_{2} \quad$ "Acontecimento natural (comum) no homem"

F3 I "Uma tipa de esport [...];"

$\mathrm{L}_{2} \quad$ "Um tipo de atividade recreativa (aula agradável);"

F4 I "Este tipo de curso [...]"

$L_{2} \quad$ "Este método de ensino [...]"

$\begin{array}{lll}\text { F5 } & \mathrm{I} & \text { "Narrativos (narrativas)" } \\ & \mathrm{L}_{2} & \text { "Redações" }\end{array}$

F6 I "As concepções da educación do Brasil"

$\mathrm{L}_{2} \quad$ "Os conceitos de cultura (conhecimento) no Brasil" 
Observando-se, em 1, a combinação lexical identidade nacional percebemos que ela aparece sem a devida caracterização e, portanto, sem a expressividade semântica reconhecida na composição independência política, um cunho já estabelecido e adotado nas áreas de História e Ciências políticas. Em 2, a expressão fenômeno humano se afasta consideravelmente de acontecimento natural (comum) no homem, correspondente à intenção do falante. Em 3, numa tentativa improcedente no emprego de uma locução adjetiva de esporte (prep+subst), funcionando como modificador para a caracterização improcedente de um tipo de aula, identifica-se a palavra esporte com "recreação", "lazer", "descontração", por inferência, o que causa na interlíngua 0 apagamento da idéia pretendida, adequadamente recuperada em $\mathrm{L}_{2}$. Também em 4, no registro tipo de curso por método de ensino, perde-se a idéia do falante devido à impropriedade das escolhas lexicais envolvidas no sintagma composto pelo núcleo tipo e seu modificador de curso mal representados. Em 5, a confusão se faz sentir na estruturação do texto (descrição $\mathrm{x}$ narração) relacionada agora com a terminologia própria da Teoria literária; emprega-se narrativas em lugar de redações. No registro 6 , em concepções de educación encontra-se um falso cognato, pois a palavra educación, em espanhol, está semanticamente relacionada à education, em inglês, que quer dizer "cultura", "conhecimento".

No conjunto seguinte temos:

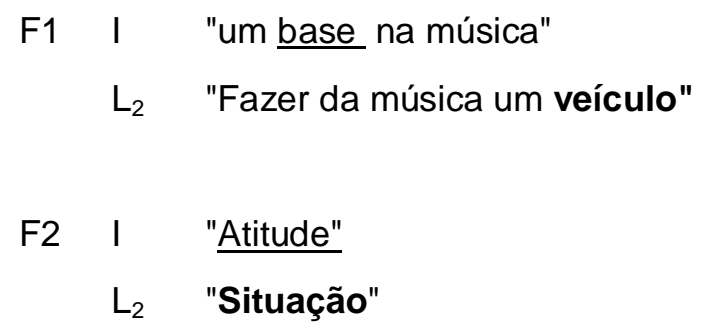

F3 I "[...] é o comida, o conceito de "por kilo" é muito bom [...]"

$\mathrm{L}_{2} \quad$ "[...] é a comida, o tipo (a espécie, a caracterização) de "por kilo" é muito bom $[\ldots]^{\prime \prime}$

\author{
F4 I "nossa figura" \\ $\mathrm{L}_{2} \quad$ "Nosso representante"
}


Em 1, verifica-se uma falha na estruturação sintática, considerando as relações semântico-contextuais aí implícitas: em um base na música, a palavra base substitui impropriamente veículo para que se entenda "fazer da música um veículo".

$\mathrm{Na}$ ocorrência 2, a inadequação decorre do uso de atitude em lugar de situação e na 3, na expressão o conceito de "por kilo", observa-se um neologismo que atua na morfologia; normalmente atribuímos a esse modificador preposicionado, por kilo, a função de adjunto adnominal - um epíteto para comida - mas aqui o falante "filosofou", considerando-o uma categoria abstrata; a palavra conceitos se presta a expressões como: "conceito de beleza, de bondade, de elegância", entre outros. Em 4, por seleção lexical inadequada, figura significa "representante".

Na última série das relações semânticas aqui apresentadas registramos:

\begin{tabular}{|c|c|c|}
\hline $\mathrm{F} 1$ & 1 & "Concepção do tempo" \\
\hline & $\mathrm{L}_{2}$ & "Compromisso com o horário" \\
\hline $\mathrm{F} 2$ & I & "Uma concepção fixa" \\
\hline & $\mathrm{L}_{2}$ & "Uma norma fixa" \\
\hline F3 & I & "Lista de regras" \\
\hline & $\mathrm{L}_{2}$ & "Norma pré-estabelecida" \\
\hline F4 & I & "Naturaleza" \\
\hline & $\mathrm{L}_{2}$ & "Ambiente natural (ar puro)" \\
\hline F5 & I & "[...] sinto falta da [...] transportación" \\
\hline & $\mathrm{L}_{2}$ & "[...] sinto falta de vias principais" \\
\hline F6 & 1 & "Um camino para correr" \\
\hline & $\mathrm{L}_{2}$ & "Uma pista de corrida" \\
\hline F7 & 1 & "Tenho uma conexão superlegal com minha família" \\
\hline & $\mathrm{L}_{2}$ & $\begin{array}{l}\text { "Tenho uma relação (um convívio, uma amizade) superlegal com } \\
\text { minha família" }\end{array}$ \\
\hline
\end{tabular}

Os registros de números 1, 3 e 6 apresentam problemas semelhantes.

Em 1, criou-se uma expressão original inédita, concepção de tempo para significar compromisso com horário, distanciando-se completamente do usual em $\mathrm{L}_{2}$ 
e bloqueando perceptivelmente qualquer possibilidade de decodificação concernente à intenção do falante. Nos casos 3 e 6, encontra-se um desvio que chamaríamos de uma outra alternativa de expressão, correspondendo, também, a formas inéditas de referência pela originalidade, distância do usual e um certo artificialismo, comparáveis ao caso 1, com uma diferença: não dificulta a compreensão do ouvinte: lista de regras e um camino para correr, respectivamente significando "norma préestabelecida" e "uma pista de corrida". Em 4, observa-se que ocorre analogia com palavras que apresentam semas comuns e alguma semelhança fonética, mas que soam inadequadas na expressão, do referido exemplo. Avalie-se a estrutura falta naturaleza onde o substantivo naturaleza usado indevidamente substitui "ar puro", "ambiente saudável". Em 5, a escolha apresentada se afasta da intenção do falante; alem de aparecer em espanhol, o substantivo transportación se nos afigura solto na frase atualizada para expressar a "dificuldade de locomoção", "dificuldade de acesso". Em 7, a palavra conexão traduz "relação", "convívio", "amizade".

Considerando a interlíngua e a $L_{2}$ das ocorrências exibidas no grupo $B$ com seus respectivos comentários, verificamos a inadequação na escolha lexical, apesar da existência de uma constatada relação sêmica entre os vocábulos, uma analogia bem remota, quase inaceitável da palavra ou da expressão selecionada. Neste caso, situações que ultrapassaram os limites da caracterização de mistakes chegando às raias da classificação de errors estão presentes nas falas 1, 2 e 4 do primeiro conjunto e um do 3, respectivamente: identidade nacional / independência política, fenômeno humano/ acontecimento natural, tipo de curso/método de ensino e concepçào de tempo/compromisso com o horário.

Conforme observado, a contaminação semântica apresentou casos com diferentes níveis de distanciamento nas relações sêmicas entre interlíngua e $L_{2} 0$ que gerou uma série de dificuldades caracterizadas como mistakes sendo que algumas beiraram as raias dos errors. ${ }^{36}$

\footnotetext{
${ }^{36}$ DULAY, H. afirma, diante da dificuldade de se estabelecer a diferença entre mistakes e errors, "usamos errors para nos referirmos a quaisquer desvios provenientes das realizações da linguagem, não importando a distância e as causas que esses desvios possam apresentar". 1974. p.139.
} 


\subsubsection{0 classes de palavras: entrelaçamentos}

Dada a importância da distinção entre as classes de palavras para a organização morfossintático-semântica nas falas dos entervistados, enumeraremos alguns casos relativos a essa problemática, pois dessa avaliação decorre a classificação dos errors e dos mistakes. Assim sendo, as classes serão apreciadas quanto às suas respectivas funções, flexões, incluindo abordagens semânticas e respectivas peculiaridades em dois grupos: um destinado aos entrelaçamentos lexicais entre palavras de diferentes classes e outro entre palavras da mesma classe gramatical.

3.1.10.1 Entrelaçamentos lexicais: palavras de diferentes classes

Neste item serão apresentados os entrelaçamentos de acordo com a classificação morfológica em adjetivos, substantivos, advérbios, verbos e construções (conjunções, preposições).

\subsection{Adjetivo/substantivo}

a) Comparemos a interlíngua e a $L_{2}$, no que se refere ao problema da caracterização:

F1 I "O dinâmico"

$\mathrm{L}_{2} \quad$ "O dinamismo"

Nominalizou-se o adjetivo dinâmico pelo acréscimo do determinante $\boldsymbol{o}$, devido à dificuldade em formar o substantivo através do sufixo -ismo.

Em: 
F1 I "uma coisa que dá bom para o corpo"

$\mathrm{L}_{2} \quad$ "Uma coisa que faz um bem ao corpo"

Registra-se nessa fala dá bom, devido ao desconhecimento da expressão fazer um bem formada pela substantivação do advérbio.

$\mathrm{Na}$ afirmação:

F1 I "eu sento triste, eu sento saudade"

$\mathrm{L}_{2} \quad$ "eu sinto tristeza, eu sinto saudade"

nota-se falta de paralelismo entre as classes de palavras. Ignora-se a derivação sufixal pelo acréscimo do sufixo -eza ao radical triste para formar o substantivo tristeza respeitando-se as respectivas funções desses componentes enquanto complementos do verbo sentir, restabelecendo a correspondência morfossintática.

Verifiquem-se agora as falas:

F1 I "um estrutura tópica"

$\mathrm{L}_{2} \quad$ "um tópico estrutural"

F2 I "aqui faz um quinte fenomenal"

$\mathrm{L}_{2} \quad$ "Aqui faz um calor fenomenal"

F3 I "[...] estudar vocabulário, estructurais verbais [...]"

$L_{2} \quad$ "[...] estudar vocabulário, estruturas verbais $[\ldots] "$

F4 I "[...] que tem tanta deferença que [...] exagerado, eu acho"

$\mathrm{L}_{2} \quad$ "[...] que tem tanta diferença que é um exagero, eu acho"

Em 1, constata-se a falta de conhecimento de que o núcleo da expressão é o substantivo tópico e não estrutura, que aparece modificada pela forma improcedente tópica, na função de adjetivo, e acabou gerando a confusão.

Em 2, quinte, por associação ao espanhol cuiente ou caliente procede-se à nominalização do adjetivo quente no lugar do substantivo adequado, $\underline{\text { calor }}$. 
Usa-se, em 3, o adjetivo estructurais pelo substantivo estruturas, devido à provável contágio por contaminação da terminação do adjetivo plural (verbais) para o substantivo, mantendo-se o $\boldsymbol{c}$ do Inglês structural .

O particípio exagerado, presente em 4, um adjetivo que substitui um sbustantivo, o deverbal exagero por desrespeito ao processo de derivação regressiva inerente e estabelicido para obtenção dessa forma.

A partir dessas falas verifica-se que o adjetivo vem preencher o espaço destinado ao substantivo, descaracterizando essa classe de palavras, tanto pelo uso indevido do artigo e pelo desconhecimento da possibilidade de substantivação de advérbio quanto pela impropriedade das nominalizações resultantes de processos de derivação (sufixal e regressiva), incluindo, ainda, a transferência de morfemas de uma para outra classe de palavras.

\subsection{Substantivo/adjetivo}

Observemos agora o uso dos substantivos nas falas:

$$
\begin{array}{lll}
\text { F1 } & \text { I } & \text { "[...] que são verdade" } \\
& L_{2} & \text { "[... que são verdadeiras (comuns)" }
\end{array}
$$

Ressalta-se, nesse caso, o desconhecimento do significado e do uso das palavras, cuja troca acarretou uma estranheza morfolexical.

Em F2:

$$
\begin{array}{lll}
\text { F2 } & \text { I } & \text { "Um estrutura tópica" } \\
& L_{2} & \text { "Um tópico estrutural" }
\end{array}
$$

usa-se o substantivo estrutura pelo seu correspondente adjetivo estrutural: desconsiderando-se as relações entre essas formas e suas respectivas funções na referida expressão. 


\section{Em F3:}

$$
\begin{array}{lll}
\text { F3 } & \text { I } & \text { "As coisas gramáticas" } \\
& \mathrm{L}_{2} \quad \text { "As coisas gramaticais" }
\end{array}
$$

emprega-se o substantivo pelo adjetivo por dificuldade na distinção entre as formas do substantivo gramática e do adjetivo gramaticallgramaticais ou por incapacidade na criação do adjunto adnominal preposicionado de gramática (gramaticais).

\section{Em F4:}

\section{F4 I "Um cidade assi grande, perículo [...]" $\mathrm{L}_{2} \quad$ "Uma cidade assim grande, com tanto perigo [...] (perigosa)."}

improvisa-se uma forma perículo, provavelmente inspirada no latim clássico periculum, graças a conhecimentos anteriores.

Nesse caso a expressão adjetiva com tanto perigo corresponderia também, ao adjetivo perigosa.

Em F5:

$$
\begin{array}{lll}
\text { F5 } \quad ~ & \text { I No sê que algo bobage" } \\
& \mathrm{L}_{2} \quad \text { "Não sei que coisa boba" }
\end{array}
$$

recorre-se à palavra bobage, um substantivo, para qualificar algo equivalente à palavra coisa subentendida em algo, conforme se lê em $\mathrm{L}_{2}$.

Em F6:

$$
\begin{array}{lll}
\text { F6 } & \mathrm{I} \quad \text { "Um esporte da riqueza" } \\
& \mathrm{L}_{2} \quad \text { "Um esporte de rico" }
\end{array}
$$

transfere-se, do espanhol para o português, a expressão esporte da riqueza, conforme registrada na interlíngua. Neste caso, o uso do substantivo tornou estranho o caracterizador do núcleo esporte. 


\section{Em F7:}
F7 I "[...] outro sistema de política" $\mathrm{L}_{2} \quad$ "[...] outro sistema político"

emprega-se uma locução adjetiva de política, sendo o uso do adjetivo político mais adequado à norma, nessa expressão.

Em F8 e F9:

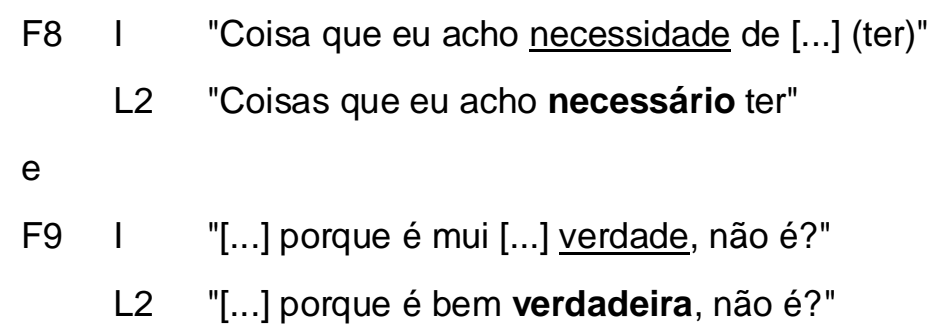

a impropriedade lexical decorre respectivamente do uso dos substantivos, necessidade e verdade ignorando-se as correspondentes formas adjetivas necessário e verdadeira registradas em $\mathrm{L}_{2}$.

Nas falas que seguem:

F10 I "Ele fuê realmente obsessão com o subjuntivo"

$\mathrm{L}_{2} \quad$ "Ela (a professora) era realmente obcecada pelo subjuntivo"

$\begin{array}{lll}\text { F11 } & \text { I } & \text { "... }] \text { o ano acadêmico na Inglaterra é diferência daqui" } \\ & L_{2} & \text { "[... }] \text { o ano acadêmico na Inglaterra é diferente daqui." }\end{array}$

F12 I "Eu acho que aprendendo uma língua está muito psicolôgia, muito [...]"

$\mathrm{L}_{2} \quad$ "Eu acho que aprender uma língua é muito psicológico, [...]"

usam-se, automaticamente, sem hesitar, mas de maneira imprópria, os substantivos obsessão, diferência e psicolôgia em lugar dos adjetivos correspondentes por desconhecimento do processo de derivação atralado a essas formas. 


\section{Em F13:}

F13 I " [...] os diplomáticos não está tramitado para com os coletivo"

$\mathrm{L}_{2} \quad$ "[...] os diplomatas não estão comprometidos com os problemas do povo, população (pessoas)."

observa-se uma forma inusitada e vaga de alusão ao povo (sociedade): os coletivo. Instaura-se uma nominalização duplamente anômala: o determinante no plural os em discordância com o núcleo coletivo no singular, uma escolha que atribuímos à incapacidade de criação do substantivo coletividade, caracterizando um problema de referência lexical paralelamente à mistura de classes. Observa-se ainda que o adjetivo diplomáticos substitui o substantivo diplomatas, ressaltando mais um caso de inacessibilidade às nominalização.

Ficou bem evidente na fala dos entrevistados uma dificuldade em nomear e caracterizar. Observou-se que as ocorrências do emprego do substantivo pelo adjetivo foram motivadas por problemas de derivação (nominalizações) e de escolha lexical.

\subsection{Adjetivo/advérbio}

Observemos agora o comportamento dos falantes, quanto ao uso de caracterizadores (adjetivos) e de circunstantes (advérbios):

F1 I "Essas escolas de comunicações [...] têm muito internacional"

$\mathrm{L}_{2} \quad$ "Essas escolas de comunicação têm (existem) muitas internacionalmente"

F2 I "Realmente pequeño"

$\mathrm{L}_{2} \quad$ "Realmente (na verdade) pouco" 
F3 I "[...] (é interessante) aprenda a História do Brasil porque eu conhece um menor.

$\mathrm{L}_{2} \quad$ "[...] (é necessário) aprender mais sobre a História do Brasil porque eu conheço um pouco"

F4 "Ele era um artista demais."

$\mathrm{L}_{2} \quad$ "Ele era um excelente artista."

F5 I "[...] aquele negócio onde [...] eu fico no cavalo bom."

$\mathrm{L}_{2} \quad$ "[...] aquele negócio onde eu fico bem no cavalo."

F6 I "[...] ajudar fazer compras, coisas assi, que eu fazia não bom, não é?"

$\mathrm{L}_{2} \quad$ "[...] que eu não fazia bem."

F7 I " "[...] é difícil achar uma coisa que dá bom para o corpo."

$\mathrm{L}_{2} \quad$ "[...] é difícil achar um coisa que faz bem à saúde."

F8 I "Se você não fala português bem, você não tem autoridade bem."

$\mathrm{L}_{2} \quad$ "Se você não fala bem (o) português, você não mantém uma boa autoridade."

F9 I "Eu não estou muito ruim da língua."

$\mathrm{L}_{2} \quad$ "Eu não estou muito mal na língua [Eu não sou muito ruim na língua (muito ruim em inglês)]."

Tem-se em 1, na interlíngua, a presença de um adjetivo internacional, absolutamente incompatível com o contexto que requer 0 advébio internacionalmente para representar a circunstância de modo.

Em 2 e 3 verifica-se, respectivamente, um problema de natureza morfossemântica. Questionado se havia sentido falta de sua alimentação, o falante se manifestou, conforme $\mathrm{F}_{2}$, com um Realmente pequeño. Registrou-se uma confusão entre o adjetivo pequeño (influência espanhola) e pouco um advérbio em $\mathrm{L}_{2}$. Em F3, outra confusão se verifica entre um menor e pouco uma forma adjetiva 
substantivada para suprir a falta do advérbio, gerando um problema especificamente semântico pelas referências mal estabelecidas.

Em 4, tem-se o problema entre o advérbio demais e o adjetivo excelente, aproximados pela noção de intensidade que os caracteriza.

Em 5, a mistura de classes bom/bem e o deslocamento delas nas expressões cavalo bom por fico bem, geram mudança de referência provocando ambigüidade e dificultando a compreensão da fala. A mesma mistura de classes, bem ( advérbio) por bom/boa (adjetivo) e vice-versa, se verifica em 6, 7 e 8.

Em 9, nota-se o item lexical impropriamente usado, o adjetivo ruim em lugar do advérbio mal; uso aceitável com o verbo ser em $L_{2}$ : sou ruim na língua.

Conforme verificado, o uso de adjetivos em lugar de advérbios e vice-versa, configura-se como um problema léxico-sintático.

\subsection{Advérbio / adjetivo / substantivo}

A mistura de classes gramaticais ainda se observa em:

F1 I "[...] um país interessante e fica culturalmente"

$\mathrm{L}_{2} \quad$ "[...] um país interessante e fica importante para a cultura"

F2 I "Paguei demais, exageradamente"

$\mathrm{L}_{2} \quad$ "Paguei demais, um exagero (uma quantia exagerada)"

F3 I " "[...] querem falar só Inglês. Só Inglês exagerado"

$L_{2} \quad$ "[...] querem falar só Inglês. Só Inglês a toda hora (a todo momento)"

F4 I " [... ] isso não quer dizer que você fala o máximo"

$\mathrm{L}_{2} \quad$ "[...] isso não quer dizer que você fala muito bem" 
F5 I "[...] não sê encontrar qualquer persoa dentro de meia hora o máximo aqui, não."

$\mathrm{L}_{2} \quad$ "[...] não sei encontrar uma pessoa dentro de meia hora no máximo aqui, não."

F6 I "Geralmente eu fiquei vontade aqui."

$\mathrm{L}_{2} \quad$ "Realmente eu fiquei à vontade aqui."

F7 I "Eu acho que eu deve fazer uma procuração muitos detalhes com professor."

$\mathrm{L}_{2} \quad$ "Eu acho que eu preciso fazer uma busca (procura) com muitos detalhes [bem (muito) detalhada] de (um bom) professor."

Em 1 e 2 nota-se que a inadequação no uso de advérbios culturalmente e exageradamente, exibindo um sufixo destonante ao contexto, em lugar dos respectivos substantivos cultura e exagero, desequilibra a estrutura sintática da frase.

Em 3, usou-se o adjetivo exagerado com valor de advérbio. A expressão adverbial formada por uma locução, a toda hora, encaixa-se melhor no contexto, desfazendo uma eventual ambigüidade.

Em 4, substantivou-se (nominalizou) o adjetivo máximo em lugar de uma expressão adverbial muito bem, afetando a harmonia sintática da frase.

Em 5, a confusão se dá entre substantivo o máximo e a locução adverbial no máximo com significado de "não além".

A mesma confusão na distinção das classes verifica-se em 6 e 7, respectivamente entre $\mathrm{o}$ uso do substantivo vontade pela locução adverbial à vontade e o da expressão muitos detalhes pela locução adverbial com muitos detalhes.

Em 7, a expressão muitos detalhes, além de ter sido usada em lugar da locução (sintagma) adverbial com muitos detalhes, evidencia a incapacidade do uso do particípio adjetivo detalhada.

Evidencia-se nos casos apresentados nesse item a dificuldade na distinção de relações entre advérbios, adjetivos e substantivos, configurando-se mais uma vez um problema léxico sintático. 


\subsection{Substantivos e verbos}

Passemos a apreciar o uso dos substantivos e dos verbos nas falas:

F1 I "[...] a poluição e as coisas que são verdade para toda centros urbanos do mundo."

$\mathrm{L}_{2} \quad$ "[...] a poluição e as coisas que existem em todos os centros urbanos do mundo."

F2 I "Senti uma falta nos coisas de comida."

$\mathrm{L}_{2} \quad$ "Senti falta das coisas de comer (alimentos)"

F3 I "Eu acho que falta primeira é na área comum, nos restaurantes."

$\mathrm{L}_{2} \quad$ "Eu acho que a falta principal se encontra nos locais públicos, nos restaurantes (comunicações fora da Embaixada)."

$\mathrm{Na}$ fala 1, o verbo existir foi substituído pelo verbo ser seguido pelo substantivo verdade. Registra-se nesse caso uma confusão entre esse substantivo e verbo existir, mais indicado para anunciar a presença de elementos da natureza urbana.

Dando seqüência às dificuldades, ressaltamos ainda as ocorrências 2 e 3 que concentram um problema de ordem sintático-morfológica: os falantes demonstram, como se acha implícito no contexto, a não identificação da função de uma palavra o verbo faltar, automatizado por eles como nome (substantivo). Por esse motivo, não percebem a possibilidade de uma mesma forma lexical poder exercer diferentes funções quando se lhes pergunta o que mais falta aqui no Brasil e o que mais falta nos Cursos de Português para Estrangeiros. Daí a resposta às respectivas perguntas: casualmente correta em 2 por demonstrar uma falha na distinção entre falta (verbo) e falta (substantivo), o que volta a se repetir em 3 pelo não reconhecimento das referidas classes.

Queremos crer que essa confusão se deva ao fato de os falantes não perceberem o tipo de flexão atrelada a essas respectivas classes de palavras separadamente: o substantivo se flexionando pelo acréscimo de morfemas de gênero e número em nível sintagmático e o verbo em nível paradigmático, através dos morfemas encontrados nas conjugações. 


\subsection{Conjunção e advérbio}

Comparemos a seguir as formas destacadas na interlíngua e na $L_{2}$ :

F1 I "[...] o gramática do português é difícil por as pessoas que fala inglês, mas eu acho que eu aprende português da rua com os lojas [...]"

$L_{2} \quad$ "[...]; infelizmente* eu fui aprender português coloquial com os lojistas $[\ldots] "$

$\mathrm{O}$ advérbio infelizmente sugerido em $\mathrm{L}_{2}$, está subentendido no contexto da interlíngua: ele representa bem a critica (o desabafo negativo) implícita na fala do entrevistado. Houve uma troca de classes gramaticais: usou-se a conjunção mas aleatoriamente escolhida para uma função que não corresponde à intenção do falante, portanto, sem procedência, pois acabou ficando isolada, sem relação com o restante do texto.

Para contestar uma idéia contida na oração anterior, usou-se mas, uma conjunção adversativa, cuja opção julgamos se deva ao fato de essa conjunção relacionar idéias opostas. Essa escolha acarretou infundadas interpretações: foi difícil, mas eu aprendi, para significar "apesar de ser difícil, eu aprendi", ambas incompatíveis com a intenção do falante que encontra correspondência em infelizmente, tive de encontrar outras alternativas para aprender. Acreditamos que se procurou encontrar em mas a idéia negativa contida em infelizmente, donde a inadequação atualizada.

Ressaltam-se, no caso, valores desconexos e incoerentes entre a conjunção e o advérbio e suas respectivas relações sintático-semânticas dentro de um contexto. Essas duas classes de palavras, a primeira responsável pela função de relacionar orações e a segunda, de caracterizar diferentes circunstâncias misturaram-se, gerando conflito na interpretação do texto. 


\subsection{Conjunção e preposição}

Ainda referente ao uso de instrumentos gramaticais, observemos:

F1 I "[...] eu deve dar os aulas pra você porque meu experiência aprendendo português."

$L_{2} \quad$ "[...] eu posso dar aulas para você pela minha experiência em aprender português."

F2 I "[...] eu não sube sobre entra aero."

$L_{2} \quad$ "[...] eu não sabia como entrar no aeroporto."

F3 I "Gentes como Estado de São Paulo não fizi nada especial para nós."

$\mathrm{L}_{2} \quad$ "Os representantes do Estado de São Paulo não fizeram nada especial para nós."

Constata-se em 1 uma confusão entre conjunção causal porque e preposição per (pela). Em 2 o problema se dá entre a preposição sobre e a conjunção como e em 3, entre a conjunção como e a preposição de.

Ressalta-se aqui a dificuldade na distinção entre os instrumentos gramaticais que ligam palavras estabelecendo, entre elas, uma relação de dependência (preposições) e aqueles que relacionam orações num mesmo enunciado (conjunções).

\subsection{Advérbio e indefinido}

Na seqüência dos problemas de uso das classes de palavras, encontramos:

F1 I " [...] e também nós aprendemos só gramática, sem vocabulário."

$\mathrm{L}_{2} \quad$ "[...] e também nós aprendemos muita gramática e pouco vocabulário." 
Uso indevido do advérbio só (somente) e da preposição sem, gerou alteração na mensagem por serem formas radicais e rígidas que o falante tentou usar para enfatizar a ineficiência do curso, em vez de palavras mais flexíveis: muito(a) e pouco(a). Tais escolhas, além de não se adequarem à realidade, deixam implícita uma confusão de classes de palavras vinculada aos pronomes indefinidos variáveis muito(a)/pouco(a), formas expressivas que teriam ficado semanticamente mais apropriadas ao tipo de informação por se aproximarem mais da expressão do pensamento e intenção do falante, dado o caráter semântico impreciso, indeterminado e genérico dos indefinidos.

3.1.10.1.9 Formas nominais: entrelaçamentos extensivos a outras classes de palavras

Apresentaremos, nesta parte, os registros relativos ao uso das formas nominais do verbo, a fim de dar continuidade ao trabalho que vimos realizando com as dificuldades reveladas pelas falas dos entrevistados.

\subsection{Deverbal e infinitivo}

Analisemos as falas:

$$
\begin{array}{llll}
\text { F1 } & \text { I } & \text { "[...] e também ele quis [...] } \text { ensaio }^{*} \text { gramática." } \\
& \mathrm{L}_{2} & \text { "[...] e também ela só queria treinar gramática," } \\
\text { F2 } & \text { I } & \text { '[...] se eu conseguia quero ir trabalho em [...] na hípica." } \\
& \mathrm{L}_{2} & \text { "[...] se eu conseguir quero trabalhar na hípica." }
\end{array}
$$

Usaram-se, na ordem da seqüência, falas 1 e 2 os verbos ensaiar com significado de "treinar" e o verbo trabalhar na $1^{\underline{a}}$ pessoa do singular do presente do indicativo, forma que coincide com os respectivos deverbais ensaio e trabalho, o que 
levanta a hipótese de o falante ter usado conscientemente os substantivos ensaio e trabalho (gramaticalmente deverbais) no lugar reservado ao infinitivo ensaiar e trabalhar - gerando uma mistura de classes entre os deverbais e o infinitivo.

\subsection{Infinitivo e deverbal}

F1 I I " [...] como eu não consegui bolsa estudar aqui no Brasil."

$L_{2} \quad$ "[...] uma bolsa de estudos aqui no Brasil."

Nesta fala, opera-se o mecanismo inverso ao anteriormente visto, uma confusão entre infinitivo e deverbal

\subsection{Infinitivo e gerúndio}

Ainda sobre o infinitivo temos a fala:

F1 I "[...] há que resolver aqui outro a sala que tá totalmente a ver com ninguém falar (tá lá, sem ninguém na sala ou em uma sala vazia)."

$L_{2} \quad$ "[...] tem de resolver isso (esse problema) em outra sala igual a esta, onde não há ninguém falando."

onde se usa sem procedência o infinitivo falar, uma forma mais pontual, com remotíssima probabilidade de se ter pensado na expressão a falar, caracterizando uma ação progressiva virtual, como acontece na linguagem em Portugal, em lugar do gerúndio falando, uma progressiva real. Registra-se assim a confusão entre o infinitivo e o gerúndio. 


\subsection{Gerúndio e infinitivo}

Situação inversa à anteriormente exposta ocorre em:

F1 I "[...] nós temos o tradição mudando sua nome com você tem um casamento [...]"

$\mathrm{L}_{2} \quad$ "[...] nós temos a tradição de mudar seu nome quando você se casa."

onde se encontra na interlíngua uma inadequação em que o gerúndio aparece erroneamente em lugar do infinitivo na função de complemento nominal; o modificador de mudar, constituído por prep+inf, conforme $L_{2}$, recupera a gramaticalidade da expressão.

\subsection{Gerúndio e particípio}

Ainda sobre o uso do gerúndio acrescente-se:

$$
\begin{array}{ccc}
\text { F1 } & \text { I } & \text { "Eu acho que a cultura aqui está muito relaxando." } \\
& \mathrm{L}_{2} \quad \text { "Eu acho que a cultura aqui está muito relaxada." }
\end{array}
$$

Nesta fala, atribui-se o uso inadequado de relaxando a uma influência direta do inglês com a tradução literal da palavra ralaxing, na função de predicativo do sujeito, em vez da forma consumada de particípio relaxada, flexionada no feminino.

\subsection{Gerúndio e deverbal}

Considere-se a ocorrência: 


\section{F1 I "Você vai aprender pelo falando." \\ $L_{2} \quad$ "Você vai aprender pela fala."}

Quanto a esta fala, ressalta-se na interlíngua um aspecto de nosso interesse, a nominalização do gerúndio verificada pela presença do determinante o em pelo falando, novamente por influência do inglês, by speaking, uma transferência negativa, em lugar do deverbal fala. Assinala-se assim o gerúndio e o deverbal.

\subsection{Locução prepositiva e gerúndio}

Note-se a influência da expressão inglesa together with em:

F1 I "[...] um sistema de governo muito complexo - junto com (together with) o nível federal, estadual [...]"

$\mathrm{L}_{2} \quad$ "[...] unindo* o nível federal, estadual [...]"

Emprega-se uma locução prepositiva junto com introduzindo uma informação que devia ser expressa por uma oração reduzida de gerúndio, unindo, que corresponde a uma oração adjetiva relativa , conforme sugerida em $L_{2}$.

\subsection{Infinitivo e substantivo}

Atente-se a seguir para o uso do infinitivo nas falas:

F1 I " [...] eu sou chorona qualquer ser eu vou chorar."

$\mathrm{L}_{2} \quad$ "[...] eu sou chorona por qualquer problema (acontecimento, notícia) eu choro." 
Evidencia-se aqui um uso inusitado, a nominalização do infinitivo do verbo ser pela presença do determinante qualquer, ignorando-se a forma usual da língua portuguesa, a expressão com o substantivo problema, ou mesmo coisa: qualquer problema ou qualquer coisa.

\subsection{Infinitivo e adjetivo}

Na fala:

$\begin{array}{lll}\text { F1 } & \text { I } & \text { "[...] cada processo estam diferência significar." } \\ & \mathrm{L}_{2} & \text { "[...] cada processo apresenta uma diferença significativa." }\end{array}$

emprega-se erroneamente o infinitivo significar para assumir a função de adjunto adnominal pelo adjetivo mais apropriado significativa.

\subsection{Infinitivo e particípio}

Em:

F1 I I[..] uma coisa bem legal para ajudar com escrever."

$\mathrm{L}_{2} \quad$ "[...] uma coisa bem legal para ajudar (desenvolver) a escrita."

constata-se novamente a opção errônea pelo infinitivo e, ainda, sem o determinante o em lugar da forma nominalizada do particípio flexionada no feminino: a escrita, conforme correspondência em $\mathrm{L}_{2}$. 


\subsection{Infinitivo verbo e infinitivo nominalizado}

Observa-se na fala

$\begin{array}{lll}\mathrm{F} 1 & \mathrm{I} & \\ & \mathrm{L}_{2} & \text { "...] até jantar nós fomos muito descansada }[\ldots] "\end{array}$

a falta de determinante na palavra jantar criando uma indefinição em sua função sintática, se um verbo ou se um nome. Na correspondência em $L_{2}$, a presença do determinante nominaliza o infinitivo, resgatando seu valor de substantivo logicamente implícito no discurso do falante e dissolvendo a ambigüidade,

3.1.10.2 Entrelaçamentos lexicais: palavras da mesma classe

Neste item a mistura de palavras da mesma classe gramatical será avaliada sob o ponto de vista morfológico, sintático e semântico, quando pertinentes, a começar pelo advérbio.

\subsection{Advérbio: problema morfológico e semântico}

Apreciemos, nas falas a seguir, o uso dos advérbios do ponto de vista morfológico e semântico.

\subsection{Problema morfológico}

Do ponto de vista morfológico registram-se: 
F1 I "[...] é verdademente uma, vou dizer, entropia nas ruas [...]"

$L_{2} \quad$ "[...] é na verdade um, vou dizer, entupimento (congestionamento) nas ruas $[\ldots]^{\prime \prime}$

F2 I "Eu vi uma professor aqui no USP. Este fato fuê acasomente (acaso + mente)."

$\mathrm{L}_{2} \quad$ "Eu vi uma professora aqui na USP. Esse fato aconteceu por acaso."

F3 I " "[...] pensa herado e derrepentemente tudo difícil."

$L_{2} \quad$ "[...] pensa errado e de repente (repentinamente) tudo fica difícil."

Encontramos nesses casos as chamadas "aberrações" cometidas pelos entrevistados. Em substituição às locuções adverbiais, na verdade, por acaso e de repente, observa-se o acréscimo aleatório do sufixo -mente ao substantivo, uma derivação própria dos adjetivos.

Verifique-se, agora, a fala:

F1 I "[...] um sistema bastantíssimo difícil se você não tem uma professor bem."

$\mathrm{L}_{2} \quad$ "[...] um sistema muitíssimo difícil se você não tem um bom professor."

Atribuímos o processo de derivação sufixal agramatical de bastantíssimo, por um processo de transferência, uma provável associação e confusão com o superlativo muitíssimo.

\subsection{Problema semântico}

Note-se o uso de geralmente e de realmente nas falas:

F1 I "Eu acho que geralmente não é possível ficar com uma vez até uma promoção."

$\mathrm{L}_{2} \quad$ Eu acho que na verdade não é possível ficar (permanecer) a primeira vez (no país) até (ganhar) uma promoção. 
F2 I "Geralmente eu fiquei vontade aqui."

$L_{2} \quad$ "Realmente eu fiquei à vontade aqui."

F3 I "Geralmente eu vi os filmes populares."

$L_{2} \quad$ "Algumas vezes eu vejo filmes populares (ela só vê filmes de arte)."

F4 I "Geralmente eu visitou as cidades [...]"

$\mathrm{L}_{2} \quad$ "As vezes eu visitava (outras) cidades (além das capitais) [...]"

F5 I "[...] o causa esta contratos, mas realmente .[...] geralmente tudos está tranqüilo, [...]"

$\mathrm{L}_{2} \quad$ "[...] Quanto a estes contratos realmente tudo está tranqüilo (decidido) $[\ldots] "$

Nos casos registrados, verifica-se uma dificuldade na distinção semântica entre geralmente, um advérbio de freqüência, e realmente, um advérbio de afirmação Geralmente aparece repetidas vezes nas falas de 1 a 5 , refletindo um hábito sem que se alcance pela sua incompatibilidade com o contexto a correspondência semântica pretendida pelo falante, esclarecida em $L_{2}$.

Acrescente-se a fala:

F1 I "Na Inglaterra, exclusivamente, português não é uma língua onde é fácil encontrar aulas."

$\mathrm{L}_{2} \quad$ "Na Inglaterra, especificamente, português não é uma língua fácil de se encontrar aulas."

Nota-se nela a estranheza semântica gerada pela escolha aleatória do advérbio exclusivamente na interlíngua em lugar do correspondente especificamente em $L_{2}$.

Cabe ressaltar que a falta de precisão ou adequação semântica da apresentação das circunstâncias, nas falas elencadas, provoca desvios, muitas vezes responsáveis pelo apagamento da intenção comunicativa do falante, como é o caso do emprego de exclusivamente por especificamente. 
3.1.10.2.2 Adjetivo: problema morfológico, semântico e morfossemântico

O uso dos adjetivos será aqui apreciado do ponto de vista morfológico, semântico e morfossemântico.

\subsection{Problema morfológico}

Considere-se

$\begin{array}{lll}\text { F1 I } & \text { "A burocracia aqui é muito demorosa } \\ & \mathrm{L}_{2} \quad \text { A burocracia aqui é muito demorada (morosa) }\end{array}$

Nesse caso, o uso da palavra demoroso em lugar do particípio demorado despertou em nós a possibilidade de os falantes estarem registrando falhas demonstradas por insuficiência de informação sobre o emprego de adjetivos relacionados com a forma de particípio, muitas vezes nominalizado no feminino. Se considerarmos a fala $A$ burocracia aqui é muito demorosa, observamos que demorosa poderia ser interpretada como uma mistura entre morosa, um adjetivo comum, e a forma demorada, um adjetivo derivado de particípio no feminino, que o falante não conseguiu construir, mas que teria dado legitimidade ao texto.

Quanto a forma demoroso pode ter surgido, também, através de uma provável e errônea associação com a derivação encontrada em cuidadoso: cuidado (substantivo)+ sufixo -oso.

Essas situações revelam um problema morfológico semelhante ao que observamos em outros casos, ainda, alicerçados no particípio, como em:

\footnotetext{
F1 I "Nós temos uma vida muito reanimada."

$\mathrm{L}_{2} \quad$ "Nós temos uma vida superanimada."

F2 I "Eu tenho uma vida muito confortada aqui."

$\mathrm{L}_{2} \quad$ "Eu tenho uma vida muito confortável aqui."
} 
Observe-se em 1 o problema morfossemântico decorrente da confusão entre o prefixo de repetição re- e o de intensidade super-.

Encontramos, agora, em 2 o problema morfossemântico, relacionado a uma mistura de -da (desinência do particípio, no feminino) e do sufixo -vel, em que se usa indevidamente, como vemos na interlíngua, a palavra confortada em lugar de confortável. Enquanto confortada corresponde a um fato ou ação consumada resultante de um processo, representado pelo particípio, o sufixo -vel significa "capaz de", "passível de", "propenso a". Na fala, o referente vida pede, por essa razão como atributo a forma confortável, que encontra respaldo lógico na explicação: "por ser confortável, a vida me conforta" (voz ativa) e, conseqüentemente: "eu sou confortada pela vida (voz passiva). Portanto, com o uso de confortada muda-se a referência de vida para eu, criando uma incongruência - um desencontro de referências causado pela troca de morfemas, alterando o teor da informação, pois a forma mais apropriada, como vimos, para se referir à vida é confortável, "que oferece conforto" e não confortada, que recebe conforto".

\subsection{Problema semântico}

Do ponto de vista semântico, encontramos, também dificuldades na escolha lexical relacionadas ao particípio:

F1 I " [...] até jantar nós fomos muito descansada."

$\mathrm{L}_{2} \quad$ "[...] até no jantar nós ficávamos muito calados (não sabiam se comunicar)."

F2 I "[...] mas agora uma das áreas onde inglês é conhecido." $\mathrm{L}_{2} \quad$ "[...] usado."

Em ambos os casos, a inadequação semântica se deve à escolha imprópria do verbo, como se observa nos pares: descansada por calados na fala 1 e conhecido por usado na fala 2, considerando-se que descansar e conhecer têm sentidos, respectivamente, diferentes de calar e usar. 
Ainda deixam transparecer uma relação indireta com o uso do particípio a fala 1, na interlíngua, e as falas 2 e 3 , nas correspondências em $L_{2}$.

$\begin{array}{lll}\text { F1 } & \text { I } & \text { "Eu estou muito complicada." } \\ & \mathrm{L}_{2} & \text { "Eu estou muito confusa (indecisa)." } \\ \text { F2 } & \text { I } & \text { "[...] e estou nervioso sobre o programa." } \\ & \mathrm{L}_{2} & \text { "[...] e estou preocupada com o programa." }\end{array}$

F3 I "[...] o causa esta contratos, mas realmente [...] geralmente tudos está tranqüilo, $[\ldots] "$

$L_{2} \quad$ "[...] Quanto a estes contratos, realmente tudo está tranqüilo (decidido, resolvido, definido), [...]"

Criaram-se nesses casos problemas de decodificação devido aos desvios e insuficiências semânticas em adjetivos complicada, nervioso e tranqüilo que poderiam colaborar com o texto na composição de uma estrutura mínima que lhe assegurasse comunicabilidade.

Outras referências a adjetivos, não necessariamente voltadas aos particípios, mas ainda relacionadas com a semântica, merecem consideração como:

\footnotetext{
F1 I " [...] talvez aprenda a História do Brasil é muito interessante."

$\mathrm{L}_{2} \quad$ "[...] talvez aprender a História do Brasil seja muito necessário."

F2 I "Esto uma história muito interessante."

$\mathrm{L}_{2} \quad$ "Está é uma história muito confusa (séria, problemática)."
}

O falante tanto explora o adjetivo interessante por necessário (caso 1) como até para representar um julgamento negativo algo confuso (caso 2). Esse uso vicioso do adjetivo estabelece relações semânticas inaceitáveis com seus respectivos referentes, provocando impactos contextuais - uma desarmonia de idéias - que sombreiam a mensagem a ser transmitida

No entanto, quando essa palavra garante adequação, não é usada como se observa em: 
F1 I "Às vezes eu tenho um livro muito engraçado."

$\mathrm{L}_{2} \quad$ "Às vezes eu leio um livro muito interessante."

De acordo com o contexto, nesse casso, o adjetivo interessante é o que mais se aproxima da intenção do falante.

Quanto às escolhas alternativas sem encaixe semântico, vejam-se ainda:

F1 I "Você tem uma reunião bem simpático."

$\mathrm{L}_{2} \quad$ "Você tem uma reunião (um encontro) muito agradável."

F2 I "Geralmente as pessoas, aqui no Brasil, está muito simpático."

$\mathrm{L}_{2} \quad$ "As pessoas, aqui no Brasil, são geralmente muito amáveis."

Observa-se, no primeiro caso, um exemplo de metonímia, o uso de simpático qualificando a reunião - uma qualidade humana se aplica a um objeto. No segundo, apesar de haver alguma semelhança entre simpático e amáveis, a opção do falante não corresponde à sua intenção, que se encontra bem caracterizada em $L_{2}$.

Outras ocorrências podem ilustrar ainda mais esses embaraços semânticos:

F1 I "Nós não temos uma pessoa regular."

$\mathrm{L}_{2} \quad$ "Nós não temos uma professora apropriada (especialista)"

F2 I "Você precisa usa palavras mais pequenas."

$\mathrm{L}_{2} \quad$ "Você precisa usar palavras mais simples (mais fáceis)."

F3 I "[...] eu trabalhava numa loja assi para ser a "woman" [...]; não foi uma coisa grande, não."

$\mathrm{L}_{2} \quad$ "[...] eu trabalhava numa loja para ser a "recepcionista" [...]; não foi uma coisa boa (vantajosa, útil, legal)"

F4 I "[...] eu tenho um camino muit [...].. pouco largo para seguir estes pensamentos [...]"

$\mathrm{L}_{2} \quad$ "[...] eu tenho uma caminho muito longo (extenso) para seguir e (conseguir, assim,) expressar meus pensamentos ... (tenho muito que aprender)" 
Em 1, o adjetivo regular cuja intenção é a de caracterizar uma pessoa - uma professora capaz, especializada, conforme se registra em $L_{2}$, se distancia da intenção do falante.

Considere-se em 2 o uso do adjetivo pequenas qualificando impropriamente palavras por atribuir-lhe uma característica física pequenas, em vez de buscar uma adjetivação voltada ao abstrato para veicular a interpretação lógica e natural que requer o contexto; é um desvio que causa estranheza até para os mais leigos em vista da adequação semântica registrada em $\mathrm{L}_{2}$ e em 3, a palavra grande cuja correspondência se estabelece com legal que, apesar de prosaico, caracteriza a intenção do falante, opção bastante registrada nos diálogos dos jovens.

Nota-se em 4 uma provável mistura fonética entre os adjetivos largo e longo, sendo que longo ( ou extenso) caracteriza melhor essa dimensão.

Digno de nota por sua originalidade é o caso:

F1 I "[...] não somos como eu disse antes dinâmico como os brasileiros [...] e não se estático como eu acho, algumas vezes, somos lá nos Estados Unidos."

$\mathrm{L}_{2} \quad$ "[...] não somos como já disse antes dinâmicos como os brasileiros [...], e não sossegados como eu acho que somos, algumas vezes, lá nos Estados Unidos ([...] eu sinto que, nós americanos, somos muitas vezes sossegados)."

Usou-se o adjetivo estático provavelmente pelo fato de ser contrário a dinâmico, uma inadequação lexical por escolha imprópria e estranha, pois a intenção é: caracterizar o americano de "parado", "sossegado", "tranqüilo".

\subsection{Problema morfossemântico}

Considere-se, a seguir, a fala: 
F1 I " [...] que é a coisa mais surpreendida sobre o Brasil."

$L_{2} \quad$ "[...] Qual é a coisa mais surpreendente no Brasil (pergunta indireta)."

Destaca-se nela a presença de uma das variantes lexicais correspondentes ao verbo surpreender. Para se estabelecer as relações entre forma e significado de algumas derivações sufixais oriundas desse verbo, torna-se necessária a compreensão do contexto, que vai definir a função exercida por essas respectivas formas, evitando possíveis confusões na interpretação do texto.

Há, contudo, uma relação bastante significativa entre os adjetivos surpreendente/surpreendida/surpresa, como percebemos em:

- A informação mais surpreendente ("que surpreende", "que causa surpresa" na forma ativa).

- Fui surpreendida pela informação (ser + particípio na forma passiva).

- Fiquei surpresa com a informação (ficar + adjetivo em que a forma adquire o significado de: "admirada", "perplexa").

\subsubsection{Instrumentos gramaticais}

A seguir, ocupar-nos-emos do uso das conjunções e das preposições.

Embora estas classes não exerçam propriamente uma função sintática, por serem meros conetivos, esses recursos lingüísticos respondem pelas relações sintático-semânticas estabelecidas no contexto em função da intenção dos falantes, evidenciando-as.

\subsection{Conjunção}

Considerem-se as falas da interlíngua e suas respectivas correspondências: 
F1 I "Não é possível aprender, mas durante o primeiro ano eu tentei bem escutar português."

$\mathrm{L}_{2} \quad$ "Não foi possível aprender, embora durante o primeiro ano eu tentasse bastante ouvir português."

ou

"Durante o primeiro ano eu tentei muito ouvir português, mas não foi possível aprender."

F2 I " [...] na Inglaterra os colégios ensina francês, alemão, espanhol porque [...] (português) [...] normalmente não [...]"

$\mathrm{L}_{2} \quad$ "[...] na Inglaterra os colégios ensinam francês, alemão, espanhol, mas português normalmente não [...]"

F3 I "[...] uma pessoa que vem aqui precisa o vocabulário porque as pessoas do Brasil estão muito simpático com estrangeiros."

$\mathrm{L}_{2} \quad$ "[...] uma pessoa que vem para cá (Brasil) precisa de vocabulário embora os brasileiros sejam muito amáveis com os estrangeiros."

F4 I "Seria ridículo que eu possa dissir ali (no Chile) se eu conheço América Latina e nunca passei nenhum forma de tempo aqui no Brasil."

$\mathrm{L}_{2} \quad$ "Seria ridículo se eu dissesse (fosse dizer) que eu conheço a América Latina e nunca passei nenhum período de tempo aqui no Brasil."

Em 1, a conjunção adversativa mas introduziu erroneamente uma oração coordenada adversativa em vez de uma subordinada adverbial concessiva com embora como encontramos na primeira opção em $L_{2}$.

Nota-se em 1 uma confusão entre conjunção adversativa e concessiva. Apesar de existir uma íntima relação entre essas conjunções mas e embora, elas se diferenciam na função de conectores: a primeira é coordenativa, enquanto a segunda, subordinativa. Portanto, as relações que se estabelecem entre as idéias é que vai determinar a escolha das conjunções em nível de coordenação ou de subordinação. Assim, mas relaciona, na seqüência da fala 1, uma idéia independente, contrária à que lhe precede, coordenando-se a ela e embora 
estabelece uma relação de dependência representando uma concessão em relação a uma oração principal, à qual se subordina.

Dessa forma, na interlíngua, o uso de mas se justificaria pela inversão das idéias, como se registra na opção 2 , em $L_{2}$, que representa adequadamente a intenção do entrevistado. Caso contrário, exigir-se ia o uso de embora de acordo com os preceitos da norma culta que nos serve de parâmetro, mantendo nossa atenção e respeito às possibilidades usuais em língua falada.

Em 2, usa-se uma conjunção subordinativa causal porque em lugar de mas, coordenativa adversativa, para relacionar as idéias opostas comprometendo as relações semânticas entre elas.

Em 3, comprometendo a natureza da informação, apresenta-se a conjunção causal porque em substituição à concessiva embora gerando um problema de ordem sintático-semântico e estrutural.

Em 4, a confusão se dá entre a conjunção integrante que e a condicional se e vice-versa.

Os casos apresentados evidenciaram o uso indevido das conjunções adversativas, causais e concessivas, integrantes e condicionais. Essa escolha inadequada dos conectivos desvirtua-lhes a própria natureza, função e, conseqüentemente, a informação do texto, pois estabelece relações semânticas diferentes das pretendidas, que acarretam idéias incongruentes pela falta de lógica e coerência de raciocínio, distorcendo as mensagens da fala.

\subsection{Preposição}

O item, a seguir, destina-se às relações estabelecidas pelas preposições:

F1 I "Eu gosto muito para* conversar, falar, aprender $\underline{\text { de }^{\star *}}$ outras persoas $[\ldots] "$

$\mathrm{L}_{2} \quad$ "Eu gosto muito de conversar, falar, aprender com outras pessoas [...]" 


\section{F2 I "[...] eu sento saudade muito forte para meu país [...]" \\ $\mathrm{L}_{2} \quad$ "[...] eu sinto saudade muito forte de meu país [...]"
F3 I "Eu tenho [...] e estou nevoso sobre o programa." $\mathrm{L}_{2} \quad$ "Eu estou nervosa por causa do programa."

De acordo com a seqüência das falas, na primeira delas as preposições para e de aparecem para introduzir os complementos exigidos pelos verbos transitivos indiretos: gostar (de) e aprender (com) que correspondem respectivamente a like to e learn from do inglês. A interferência de like to, como se observa em gostar para é bastante reconhecida e registrada, pois a partícula to do infinitivo inglês pode corresponder em português a: preposição a, para, em, de e por. Quanto à expressão inadequada aprender de, vemos que reflete bem a influência da expressão inglesa learn from, em que a preposição from denota origem, procedência para caracterizar a proveniência da aprendizagem, conforme raciocínio do falante que, nesse caso, corresponde a "outras pessoas".

As duas ocorrências que seguem ( 2 e 3 ) dão continuidade ao problema de ordem semântica mencionado na fala precedente; porém, com uma diferença, elas registram agora a escolha imprópria da preposição para introduzir um complemento nominal, respectivamente, saudade para meu país e nervioso sobre o programa Nota-se aí uma mudança no enfoque do problema: a inadequação da preposição na composição de um complemento verbal é transferida para os casos seguintes em que a referida impropriedade vem atuar na má composição de um complemento nominal. Os resultados, no entanto, são os mesmos: há um choque causado pelas divergências entre as preposições escolhidas (interlíngua) e as mais indicadas na língua portuguesas $\left(L_{2}\right)$ que garantem as referências semânticas necessárias a um compreensão legítima do texto.

As razões mais evidentes que resumem essas dificuldades apoiam-se em uma tendência comum: nas três ocorrências, mencionadas neste item, encontramos, como vemos nas respectivas interlínguas através das respectivas expressões, a aplicação de uma preposição pelo mecanismo falho da tradução literal que, ao gerar formas sem correspondência semântica em português, mostram-se inadaptadas ao contexto. Verificamos nessas traduções ao pé da letra um reflexo da língua materna, entendidas também como transferência negativa, causando interferências, o que 
deixa implícita uma desobediência à premissa já consagrada pela sua reconhecida funcionalidade: precisamos pensar na língua para nos comunicar adequadamente.

Observa-se em 2 um dos casos que exibem o resultado de uma tentativa sem êxito de adaptar ao texto português a tradução literal da expressão inglesa long for na composição do complemento nominal de saudade. Cria-se em para meu país um problema semântico oriundo de uma relação improcedente estabelecida entre a preposição for da referida expressão e a preposição para em português, em lugar da correta opção por de como se acha estabelecido em $\mathrm{L}_{2}$. Consideramos esse equívoco como algo atrelado à interpretação da expressão nessa estrutura, que denota "pensar no país, sentir saudade, aguardar a volta com ansiedade"; mais precisamente, inspirou-se na semântica da preposição for que representa a idéia de "objetivo", "intenção", "em busca de", para, uma ocorrência muitas vezes possível em português.

Na terceira ocorrência, o falante, provavelmente inspirado na expressão about the program, encontrou na preposição sobre - uma tradução literal de about - uma possível opção para introduzir em português o complemento nominal correspondente, mas equivocou-se; a correspondência descuidada e errônea em português sobre o programa causou interferência e acabou soando inadequada ao contexto. Em $\mathrm{L}_{2}$ encontramos o complemento nominal por causa do problema, introduzido por uma locução prepositiva.

As preposições em sua função precípua de conectores por estabelecerem relações de dependência entre as palavras aparecem escolhidas e usadas de maneira indevida, como comprovam os resgistros, respectivamente para por de, de por com e de sobre pela locução por causa de. Esse problema que atribuímos à contaminação e adoção do raciocínio semântico do inglês, influência manifestada através de transferências negativas de expressões verbais e nominais preposicionadas, se reflete nas falas desequilibrando a estrutura da língua portuguesa.

\subsection{Verbo}

Apresentam-se aqui os verbos do ponto de vista morfológico e do semântico. 
Quanto ao item morfológico, consideremos os morfemas gramaticais, as flexões de tempo e modo verbais em:

F1 I "Eu quero estudar lá no Salvador onde todo pode esperar até amanhã. Eu acho que a vida seja um poco mais tranqüila, que a gente não tinha tantas problemas da saúde se não fora a poluição [...]"

$\mathrm{L}_{2} \quad$ "[...] eu acho que a vida seria um pouco mais tranqüila, que a gente não teria tantos problemas de saúde se não fosse a poluição [...]"

F2 I "Se eu não pusei aceitar esso já está paciência sair do país."

$\mathrm{L}_{2} \quad$ "Se eu não puder aceitar isso, paciência, saio do país."

Pelo registro 1, observa-se que as maiores falhas na conjugação verbal recaem no uso dos tempos do futuro do pretérito do indicativo e nos tempos do modo subjuntivo.

Quanto à ocorrência 2, nota-se ainda a mistura de pôr e poder tendo o verbo sair, permanecido no infinitivo.

Observamos aqui dois problemas: o primeiro diretamente relacionado à estrutura da palavra, resultou da não coincidência do radical e desinência, verificada após um confronto com a composição correta dos respectivos tempo e pessoa verbal; em vez de puder, o falante usou pusei - provável mistura de pôr e poder; o segundo mostra o verbo sair erroneamente no infinitivo, sem a adequada flexão do presente do indicativo.

Do ponto de vista semântico, atente-se para a correlação da forma verbal da interlíngua e da interpretação sugerida em $\mathrm{L}_{2}$ :

F1 I "[...] eu conheci Paraguai. Nossa Senhora ichi Maria não é $\underline{e}^{\star}$ nada aqui no Brasil que pode ser tan estranho [...]"

$\mathrm{L}_{2} \quad$ "[...] não há nada aqui no Brasil que possa ser tão estranho [...]"

Revela-se nessa fala um erro quanto à escolha do verbo ser pelo haver causado pela mistura de semantemas. O uso de ser criou uma desarticulação léxicosemântica só recuperada na troca pelo haver, na respectiva pessoa e tempo verbal, como em $L_{2}$. Embora relacionado a verbos que apresentam semantemas diferentes 
(ser e haver), com atualizações diferentes nas estruturas frasais portuguesas, 0 problema concentra-se sobretudo na aplicação gramaticalmente improcedente da forma é ( verbo ser) confundida com há (verbo haver) o que revela incapacidade na distinção entre esses verbos, como comprovado na comparação interlíngua e $L_{2}$. Esse descontrole morfolexical leva-nos a supor que tenha havido, nesse caso, um embaraço de ordem fonética, resultante de uma confusão causada pela aproximação dos sons vocálicos entre as formas de terceira pessoa do singular do presente do indicativo, respectivamente é (ser) e há (haver)

As misturas lexicais quando acontecem numa mesma classe de palavras são caracterizadas por somarem formas com naturezas diferentes, ou em desacordo com as normas gramaticais estabelecidas, chegando a criar contextos que acabam por desvirtuar semanticamente a informação.

\subsubsection{Estrangeirismos}

Em continuidade à apresentação de recursos alternativos para fins de comunicação empregados pelos falantes, observemos nas falas a seguir a presença de componentes estrangeiros: o inglês e o espanhol

\subsection{Inglesismos}

Desse tipo de procedimento registramos:

$\begin{array}{ll}\text { INGLESISMOS } & \mathrm{L}_{2} \\ \text { "Rhyme pops" } & \text { "Fala de um menino (meninos) na entrada } \\ & \text { da adolescência" } \\ \text { "Exception" } & \text { "Exceção" } \\ \text { "Roads" } & \text { "Vias" } \\ \text { "Compliment" } & \text { "Cumprimento (dar parabens)" }\end{array}$




$\begin{array}{ll}\text { "Uma description"' } & \text { "Uma descrição" } \\ \text { "Coisa do means" } & \text { "Coisas do cotidiano (do meio)" } \\ \text { "[...] não educação como } & \text { "[...] não educação como comportamento" } \\ \text { manners" } & \\ \text { "[...] um super-star" } & \text { "Uma super-estrela " } \\ \text { "Eu tinha uma addiction" } & \text { "eu tinha uma veneração (obsessão)" } \\ \text { "O west"' } & \text { "O oeste" } \\ \text { "Para ser a woman" } & \text { "Para ser a recepcionista" } \\ \text { "[...] é mais show" } & \text { "[...] é mais encenação" } \\ \text { "Continuance" } & \text { "Continuidade (andamento)" } \\ \text { "Eu estava very unhappy" } & \text { "eu me sentia muito infeliz" } \\ \text { "Nós nunca [...] never found" } & \text { "Nós nunca encontramos (nunca foi } \\ \text { "Realmente I trust you" } & \text { encontrado)" } \\ \text { "It was terrible!" } & \text { "Realmente eu confio em você" }\end{array}$

Esse recurso aos inglesismos ou anglicanismos, para suprir uma dificuldade de vocabulário em português, pode ser atribuído à incapacidade de memorização, localização e seleção da palavra adequada ao contexto por parte do entrevistado, ou mesmo à sua falta de conhecimento daquela correspondente à de sua língua materna na língua-alvo em questão.

Os erros apontados não devem ser interpretados propriamente como informantes de influências estrangeiras, mas um recurso a outras fontes lingüísticas de comunicação, centralizadas, nesse caso, na exploração e adoção da língua materna para substituir palavras que os falantes não conseguem atualizar.

\subsection{Espanholismos}

Do uso de espanholismos registramos:

$\begin{array}{ll}\text { ESPANHOLISMO } & \mathrm{L}_{2} \\ \text { "Sangre" } & \text { "Sangue" }\end{array}$




$\begin{array}{ll}\text { "Camino" } & \text { "Caminho" } \\ \text { "Pensamiento" } & \text { "Pensamento" } \\ \text { "Espacio" } & \text { "Espaço" } \\ \text { "Conocimiento" } & \text { "Conhecimento" } \\ \text { "Percussión" } & \text { "Percussão" } \\ \text { "Transportación" } & \text { "Locomoção" } \\ \text { "Diferencia" } & \text { "Diferença" } \\ \text { "Policia" } & \text { "Polícia" } \\ \text { "questón (questión)" } & \text { "Questão" } \\ \text { "Seleción" } & \text { "escolha, citação, exemplo" } \\ \text { "Conversación" } & \text { "Conversação" } \\ \text { "Pronunciación" } & \text { "Pronúncia" } \\ \text { "Televisión" } & \text { "Televisão" } \\ \text { "Acción" } & \text { "Ação" } \\ \text { "[...] uma só presentación " } & \text { "[...] uma só apresentação" } \\ \text { "concepción da educación" } & \text { "conceito de cultura" } \\ \text { "siclo XXI" } & \text { "século XXI" }\end{array}$

Para nós, à presença dos espanholismos se deve à influência da língua espanhola por um processo de transferência.

A utilização bastante freqüente do Espanhol, uma aprendizagem anterior, corresponde a uma prática recorrente de compensações lexicais facilmente localizadas em uma língua que se torna disponível e favorece o falante pela sua grande semelhança com o português. $O$ desconhecimento das respectivas palavras em $L_{2}$ pode ser verificado em casos como o uso de presentación (presentation) por apresentação. Acreditamos que esse tipo de transferência seja um indício da facilidade em potencial de assimilação e enriquecimento do vocabulário do português.

Retomamos algumas justificativas alusivas à presença da língua materna, o inglês, na tentativa de se encontrar comunicação em português, para nos referirmos a essa nova situação em que o estrangeirismo se acha representado por uma língua de aprendizagem anterior à do português - o espanhol.

Atribuímos esse processo de busca e transferência de recursos para se suprirem dificuldades de expressão na língua-alvo a condicionamentos adquiridos 
durante a aprendizagem da língua anterior funcionando como automatismos que o falante aplica para acelerar sua comunicação, muitas vezes, inconscientemente. 0 conhecimento da língua anterior atua como portador de uma disponibilidade da qual os falantes se utilizam para compensarem sua falhas, mesmo acontecendo de maneira apelativa e improvisada.

Como se verificou, a presença da língua estrangeira na fala dos entrevistados configurou-se sob dois aspectos: uma transferência da língua materna do falante ou de uma outra língua de aprendizagem anterior à da língua portuguesa. Isso ocorre de maneira bem perceptível - uma transferência direta que deixa marca explícita, avaliada, no entanto, como recurso alternativo para garantir só ilusoriamente a representação do pensamento sem interromper a fluência da expressão.

A recorrência ao uso desses estrangeirismos na manifestação verbal dos falantes cria além de um certo artificialismo sinalizador da insuficiência de expressão também uma interferência que desestabiliza a normalidade da fala pela importação opcional de formas em vez da utilização das disponibilidades lexicais existentes na língua-alvo, que a tornariam mais genuína e natural.

A presença desses artifícios concorrem para desencadear a seqüência fonológica e semântica da língua portuguesa, chegando, em alguns casos, a descaracterizar sua própria natureza. 


\section{4: CONCLUSÃO}

Dando continuidade ao trabalho apresentado por ocasião de nossa Dissertação de Mestrado e preocupados em levantar as dificuldades dos falantes de português segunda língua, elaboramos esta tese com o objetivo de avaliar a escolha lexical desses falantes e suas respectivas implicações com as áreas lingüísticas: morfologia, sintaxe e semântica.

Para tanto, a partir da transcrição das entrevistas com falantes de inglês $\left(L_{1}\right)$, procedemos ao levantamento, seleção e tipificação dos erros que mais influenciaram negativamente na decodificação das mensagens, a fim de analisá-los e identificarIhes as causas, relacionando-as aos fenômenos de transferências e interferências, com base na análise contrastiva entre as duas línguas, o inglês e o português. Direcionamos nossa atenção ao problema dos nomes, formas nominais (gerúndio, infinitivo e particípio) e formas nominalizadas (derivações sufixais e deverbais)

Após examinar lado a lado, a interlíngua e a $L_{2}$ devidamente analisadas, e determinadas as possíveis causas dos desvios registrados, tendo em vista os processos morfossintático-semânticos dos errors e mistakes, apresentaremos o resultado de nossas investigações seguidas de sugestões pedagógicas com vistas a uma maior eficácia no ensino-apredizagem do português segunda língua.

Sempre voltados para nosso objetivo, em nossas conclusões, obedeceremos a seqüência dos temas correspondentes à tipificação estabelecida para nossas análises, reproduzidos na seguinte relação: uso do gerúndio, do infinitivo, sintagmas verbais, sintagmas nominais, recursos alternativos, inferência de dificuldades, recursos alternativos para as formas nominais e nominalizadas, lacunas sintáticas, uso de determinantes, inadequação lexical, inadequação de relações sintáticas, inglesismos e espanholismos.

Quanto ao uso do gerúndio, verificou-se que foi usado na $L_{2}$ tanto pelo infinitivo quanto pelo particípio. Substituiu a classe dos substantivos e de adjetivos participiais além de ser usado aleatoriamente, dificultando, muitas vezes, a compreensão das falas (cf.3.1.1).

No que se refere ao infinitivo, evidenciou-se um uso indiscriminado em português, recurso alternativo que atribuímos ao fato de esta única forma verbal corresponder a muitas formas do inglês, como é o caso das terminações em -ing 
encontradas no gerund e no participle da $\mathrm{L}_{1} \mathrm{O}$ uso abusivo dessa forma nominal cremos ainda se deva ao desconhecimento das transformações nominais correspondentes, em especial, às derivações de substantivos abstratos, a exemplo de, mudar por a mudança e de deverbais como falar por a fala. O infinitivo desempenha então, o papel de diversas classes gramaticais. Seu uso inadequado decorre tanto por não se flexionar o verbo em certas situações quanto por flexioná-lo em outras, Essa prática constante do uso do infinitivo representa um dos maiores problemas relacionados à Morfologia. Nota-se que os desvios no uso do infinitivo passoal não dificultaram a decodificação (cf. 3.1.2).

Da análise dos sintagmas verbais, observou-se a dificuldade dos falantes quanto à estruturação desses sintagmas. Além das inadequações semânticas tipo deve dar por possa, consiga dar, flexionam-se todos os componentes do sintagma como em preferimos tem, introduzem-se elos desnecessários desvirtuando a regência de verbo auxiliar, a exemplo de preciso estuda. Nesses casos também, não se constróem os tempos compostos resultando a mudança do aspecto do verbo regente tal como em li por conseguia ler, pontual por freqüentativo, adotam ir+gerúndio de forma viciosa ( vou ir), omitem o sintagma interrompendo a fala (uma vizinha também [...]), usam a preposição com para substituir as formas nominais do verbo (ficar com televisão por ficar assistindo à televisão), contaminação fonética (posso entendo), ausência do elo que relaciona os elementos do sintagma (gosto falar), não localização de sintagmas formados por ficar e/ou acabar+gerúndio responsáveis pela intencionalidade da fala (aprende português por acabei aprendendo). Portanto, os erros decorrem tanto pelas inadequações lexicais quanto pelas omissões de elementos necessários e pelo acréscimo aleatório de outros, prejudicando a comunicação.

Pela análise dos sintagmas nominais e adjetivais verificou-se não só a incapacidade de os falantes trabalharem com os mecanismos necessários a uma apropriada estruturação desses sintagmas, no sentido de estabelecer as relações sintático-semânticas apropriadas ao contexto como também a dificuldade de relacionarem núcleos (substantivos e adjetivos) e respectivos modificadores.

Tais dificuldades se evidenciam não só pela omissão das preposições, como também por questões relativas a problemas das contrações de preposições com artigos. Acrescente-se ainda além do uso indevido desses instrumentos gramaticais e de seu emprego incontrolado ocasionando construções inaceitáveis do ponto de 
vista da norma oficial da língua portuguesa, o fato de adulterarem suas relações sintáticas, gerando, muitas vezes, ambigüidades

A maneira anômala e estranha na criação e uso de alguns componentes em nível morfossintático-semântico, ou separadamente, colaboram ainda para bloquear a emissão espontânea e aceitável dos pensamentos, tornando-os incompreensíveis.

O uso dos recursos a diferentes classes de palavras, pela procura reincidente de expressões com um maior número de palavras - uma prolixidade na representação dos pensamentos, chegou, muitas vezes, a produzir redundâncias e até mesmo a estabelecer ambigüidades.

As estruturas criadas para substituir os verbos, outras vezes os adjetivos, os substantivos a até mesmo os advérbios não assimilados ou de difícil escolha ou mesmo de localização no inventário lexical dos falantes, levam a concluir que essa tendência de opção por formas analíticas se justifique pela insuficiência de treinamento relativo à derivação por sufixação - uma prática que se fez ausente, voltada à multiplicação de palavras pelo acréscimo de sufixos, portanto, funcional e recomendável pela colaboração com o enriquecimento do vocabulário, evitando assim paráfrases alternativas desnecessárias.

Verificamos, assim, uma dificuldade, que envolve a distinção entre as classes de palavras: substantivo, adjetivo, advérbio e respectivas inter-relações, para a criação de expressões compatíveis com o contexto (cf, 3.1.5).

Os problemas de nominalizações improcedentes concentram-se nas dificuldades que comprometem a comunicação; expõem com mais evidência as relações entre as formas verbais originais e as nominalizadas na criação dos nomessubstantivos.

Esses mecanismos de nominalização improcedentes decorrem de automatismos de criações lexicais inaceitáveis, geradas entre a forma verbal e a nominal latente. (cf. 3.1.6)

Sobre as falhas e as ausências lexicais, verificou-se que os entrevistados, algumas vezes, tentam suprir as necessidades de comunicação com expressões formadas por adjetivo; outras vezes, por verbos correspondentes às palavras adequadas, mas é grande o registro de lacunas, em que as palavras precisam necessariamente ser inferidas pelo contexto (cf. 3.7)

Quanto ao uso improcedente do determinante artigo verificou-se que este se caracteriza tanto pela sua ausência quando pela sua presença desnecessária ou 
indevida em função das normas gramaticalmente estabelecidas. Em ambos os casos observou-se que a generalização ou a particularização decorrente do emprego impróprio do artigo ocasionaram problemas por dificultarem a compreensão das reais mensagens emitidas pelos entrevistados.(cf. 3.8)

Tendo em vista a contaminação semântica, verificada na correspondência entre a interlíngua e a $L_{2}$ das ocorrências selecionadas para nossos comentários, em diferentes níveis de distanciamento, verificou-se a presença de mistakes pela inadequação da escolha lexical, apesar da existência de uma constatada relação sêmica entre as palavras a qual facilitou a inferência da palavra adequada ao texto. Entretanto, constatou-se que a inadequação da escolha lexical, apesar da existência de uma constatada relação sêmica entre os vocábulos, por uma analogia bem remota, quase inaceitável da palavra ou da expressão selecionada criou situações que ultrapassaram os limites da caracterização de mistakes chegando às raias da classificação de errors como nos casos do uso identidade nacional por independência política, fenômeno humano por acontecimento natural, tipo de curso por método de ensino e concepção de tempo por compromisso com o horário (cf. 3.9)

Da análise dos entrelaçamentos entre as classes de palavras (cf. 3.10), detectou-se uma dificuldade em nomear e caracterizar. Observaram-se ocorrências de falhas motivadas por problemas de derivação (nominalizações) e de escolha lexical entre substantivos e adjetivos, dificuldade na distinção de relações entre advérbios, adjetivos e substantivos, configurando-se mais uma vez um problema léxico-sintático, pelo fato de os falantes não perceberem o tipo de flexão atrelada às respectivas classes de palavras separadamente: o substantivo se flexionando pelo acréscimo de morfemas de gênero e número em nível sintagmático e o verbo em nível paradigmático, através dos morfemas encontrados nas conjugações.

Ainda sobre os entrelaçamentos assinalou-se a falta de precisão ou adequação semântica das circunstâncias, provocando desvios, muitas vezes responsáveis pelo apagamento da intenção comunicativa do falante, como é o caso do emprego de exclusivamente por especificamente. (cf. 3.10).

Considerando também a função precípua de conectores preposições, por estabelecerem relações de dependência entre as palavras, observamos seu uso indevido, problema que atribuímos muitas vezes à contaminação e adoção do raciocínio semântico do inglês, influência manifestada através de transferências 
negativas de expressões verbais e nominais preposicionadas, que se reflete nas falas desequilibrando a estrutura da língua portuguesa.

Concluiu-se que as misturas lexicais quando acontecem numa mesma classe de palavras são caracterizadas por somarem formas com naturezas diferentes, ou em desacordo com as normas gramaticais estabelecidas, chegando a criar contextos que acabam por desvirtuar semanticamente a informação.

O recurso aos inglesismos ou anglicanismos e aos espanholismos para suprir uma dificuldade de vocabulário em português, se deve à incapacidade de memorização, localização e seleção da palavra adequada ao contexto por parte do entrevistado, ou mesmo à sua falta de conhecimento da forma correspondente à de sua língua materna na língua-alvo em questão (cf. 3.10.4).

Os erros provenientes do emprego de inglesismos, entretanto, não devem ser interpretados propriamente como indicadores de influências estrangeiras, mas um recurso a outras fontes lingüísticas de comunicação, centralizadas, nesse caso, na exploração e adoção da língua materna para substituir vocábulos que os falantes não conseguem atualizar.

No emprego dos espanholismos acreditamos tratar-se de um processo de busca e transferência de recursos, para se suprirem dificuldades de expressão na língua-alvo, correspondentes a condicionamentos adquiridos durante a aprendizagem da língua anterior, automatizados pelo falante que as aplica para acelerar sua comunicação, muitas vezes, inconscientemente.

Como se verificou, a presença da língua estrangeira na fala dos entrevistados configurou-se sob dois aspectos: uma influência da língua materna do falante ou de uma outra língua de aprendizagem anterior à da língua portuguesa. Isto ocorreu de maneira bem perceptível - uma transferência direta que deixa marca explícita, avaliada, no entanto, como recurso alternativo para garantir palhativamente a representação do pensamento sem interromper a fluência da expressão.

A recorrência ao uso desses estrangeirismos cria além de um certo artificialismo sinalizador da insuficiência de expressão uma interferência que desestabiliza a normalidade da fala pela importação desnecessária de formas em vez de a utilização das disponibilidades lexicais existentes na língua-alvo, que a tornariam mais genuína e natural.

Em vista das dificuldades de interpretação das falas, concluiu-se que, em relação aos verbos, o semantema ou, conforme a tradição gramatical, a raiz — parte 
nominal do verbo - chegou a prejudicar a interpretação de algumas falas, mas as formas através de suas flexões (morfemas de modo, tempo, número e pessoa) apesar de contrariarem os conhecedores de língua, não chegaram a criar problemas de decodificação - foram, de uma forma geral compensados através de inferências pelo contexto.

Entretanto, os resultados referentes à escolha lexical inadequada gerou sérios problemas nas áreas de Morfologia, Sintaxe e Semântica. Os nomes, formas nominais e nominalizadas revelaram-se os maiores obstáculos na interpretação das falas dos entrevistados.

Tais resultados confirmam a hipótese inicial o que permite ressaltar a importância da seleção lexical para a viabilidade da efetiva interpretação dos textos dos falantes da $L_{2}$.

Com base nos resultados das investigações, sugere-se que, na elaboração de um projeto de português para estrangeiros, se

- considere, durante a seleção do material, a área de interesse do aprendiz, para a seleção do vocabulário a ser trabalhado, priorizando a freqüência a ela pertinente; uma atenção especial deverá ser dirigida às formas (derivações), significados básicos e possíveis variantes.

- crie o maior número de combinações, de acordo com os itens gramaticais estabelecidos. As transferências positivas poderão ser automaticamente apresentadas enquanto as transferências negativas (interferências) deverão ser ministradas utilizando-se a lógica existente no comportamento das palavras encontradas na língua-alvo $\left(L_{2}\right)$ - uma conscientização capaz de assegurar a retenção.

- cuide da abordagem e assimilação das variantes de nominalização, em se tratando de falantes ingleses aprendizes da língua portuguesa.

Satisfeitas essas condições, inferidas a partir dos resultados desta tese, acredita-se numa real possibilidade de tornar mais eficiente o ensino da língua portuguesa para estrangeiros. 


\section{REFERÊNCIAS}

ARONSON, B. R. Contrastive analysis revised obligatory, systematic and incidental differences between languages. Interlanguages Studies Bulletin, v. 3, p. 212-233, 1978.

CHOMSKY, N. Remarks on nominalization. Cambridge: M.I.T. Press, 1965. COSERIU, E. Teoria del lenguaje y lingüística general. Sistema, norma y habla. Madrid: Gredos, 1969.

CORDER, S.P. Introducing Applied Linguistics. London: Penguin, 1973.

CUNHA, C. Gramática moderna. Belo Horizonte: Bernardo Álvares, 1970.

DEBYSER, F. La linguistique contrastive et les interferences. In: WAGNER, E. (org.). Apprentissage du francais-langue étrangère. Paris: Larousse, 1970.

DULAY, H. C.; BURT, M. K. You can't without goofing. In: RICHARDS, J. C. (Ed.). Error analysis. London: Longman, 1974.

DULAY, H.; BURT, M.; KRASHEN, S. Language two. Oxford: Oxford University Press, 1974.

FRASER, B. The verb-particle combination in English. In $\underline{\text { JACOBS}}$, R. A.; Peter S. ROSENBAUM, P. S. (Ed.). Readings in English Transformational Grammar. New York: Academic Press, 1976.

JENSEN, J. G A Lingüística contrastiva: onde está hoje?. LITTERA Revista para Professor de Português e de Literaturas de Língua Portuguesa, v. 5, n. 13, p. 23-32, 1975.

KRASHEN, S. Second languages acquisition and second language Learning. Oxford: Pergamon, 1981.

LADO, R. Linguistics across cultures. $8^{\text {th }}$ printing, Ann Arbour: The Univiversit of Michigan Press, 1966.

LAPA, M. R. Estilística da língua portuguesa. 8. ed. rev. e acrescentada. Coimbra: Comibra, 1975.

LEES, R. B. The grammar or English moninalization. Bloomington: Indiana University/The Hague Mouton, 1960.

MARTINET, A. Elementos de lingüística geral. Trad. e adapt. de Jorge M. Barbosa. 2. ed. Lisboa: Sá da Costa, 1970. 
PAES, J. C.; LOMBELLO, E. C. (Org.). 0 ensino de português para estrangeiros - pressupostos para o planejamento de cursos e elaboração de materiais. 2. ed. Campinas: Pontes, 1997.

POTTIER, B. Linguistique générale. Paris: Klincksieck, 1974.

POTTIER, B.; AUDUBERT, A.; PAIS, C. P. Estruturas lingüísticas do português. São Paulo: Difusão Européia do Livro, 1972.

RICHARD, J. C. (Ed.). Error analysis perspectives on second language Learning. London: Longmans, 1974.

SELINKER, L. Interlanguage. In: RICHARDS, J. C. (Ed.). Erros analysis. London: Longmans, 1974.

SERAFINI, M. T. Como escrever textos. Tradução de Maria Augusta Bastos de Mattos e adaptação de Ana Luísa Marcondes Garcia. Rio de Janeiro: Globo, 1987.

THOMSON, A. J.; MARTINET, A. V. A Practical english grammar. 2nd ed. London: Oxford University Press, 1974.

ULLMANN, S. Semântica: uma introdução à ciência do significado. Tradução de J. A. de Osório Mateus. 3. ed. Lisboa: Fundação Calouste Gulbenkian, [s.d]. cap. III.

WAGNER, E. Apprentissage du français, langue étrangère. Paris: Larousse, 1970.

WEINREICH, U. Language in Contact. $6^{\text {th }}$ print. Paris: Mouton, 1968. cap. I a VI.

\section{CONSULTADAS}

ALLEN, J. P.; CORDER, S. P. Readings for applied linguistics. London: Oxford University Press, 1973.

ALLEN, W. S. Living English Structure. $4^{\text {th }}$ ed. London: Longmans, 1960.

ALVES, I. M. Neologismos. Criação lexical. São Paulo: Ática, 1990.

BASÍLIO, M. Teoria lexical. São Paulo: Ática, 1987 (Série Princípios, 88).

BECHARA, Evanildo. Moderna Gramática Portuguesa. São Paulo: Nacional, 1980. 
BECKER, B. A. Beyond translation: esthetics and language. Ed. Contemporany Perception of Language. 1995.

BIDERMAN, M. T. C. A estrutura mental do léxico. In: Estudos de filologia e lingüística. São Paulo: Queiroz/ EDUSP, 1981.

. Teoria lingüística: lingüística quantitativa e computacional. Rio de Janeiro: LTC, 1978.

BORBA F. da S. Introdução aos Estudos Lingüísticos. 2. ed. São Paulo: Nacional, 1970.

BRÉAL, M. Ensaio de semântica. Ciência da significação. São Paulo: Pontes/EDUC, 1992.

CABRÉ, M. T. La terminologia. Teoria, metodologia, aplicaciones. Barcelona: Antártida/Empúries, 1993.

CÂMARA, Jr., J. M. História e estrutura da língua portuguesa. Rio de Janeiro: Padrão, 1975.

. Princípio da lingüística geral. Rio de Janeiro: Acadêmica, 1969.

CARONE, F. B. Morfossintaxe. São Paulo: Ática, 1991.

CARVALHO, N. Empréstimos lingüísticos. São Paulo: Ática, 1989. Cap. II e III.

CASTILHO, A. T. de. Os sons. São Paulo: SE/ CENP/ UNICAMP, 1978.

Aspects of the theory of syntax. Cambridge: M.I.T. Press, 1966.

. Topics in the theory of generative grammar. Paris: University/The Hague Mouton, 1972.

. The Significance of Learner's Errors. In: RICHARDS, J. C. (Ed.). Error analysis. London: Longman, 1974.

. Gramática do português contemporâneo. 3. ed. Belo Horizonte: Bernardo Álvares, 1972.

DI PIETRO, R. Language structures in contrast. Rowley: Newbury House Publishers, 1971.

FERNANDES F. Dicionário de regimes de substantivos e adjetivos. 7. ed. Rio de Janeiro; Porto Alegre; São Paulo: Globo, 1957.

Some remarks on the action nominalization in English. New York: Academic Press, 1972, Cap. III.

FRIES, C. The structure of english. London: Longmans, 1957. 
GARCIA, O. M. Comunicação em prosa moderna. Rio de Janeiro: Fundação Getúlio Vargas, 1983.

GECKELER, H. Semântica estrutural y teoria del campo léxico. Madrid: Gredos, 1976. Cap. III, IV, VI.

Le Champ Lexical. Hier et Aujourd'hui. Westphalie:

Univiversidade de Münster, [s.d].

GENOUVRIER, E. ; PEYTARD, J. Lingüística e ensino do português. Coimbra: Livraria Almeida, 1974.

GREIMAS, A. J. Semântica estrutural. Pesquisa de Método. São Paulo: Cultrix/ EDUSP, 1973. p. 11-53.

GUIRAUD, P. A Semântica. Tradução e Adaptação de Maria Elisa Mascarenhas. São Paulo / Rio: DIFEL, 1980. cap. I a V.

JACOB, R. A.; ROSEMBAUM. Readings in englissh transformational grammar. Boston: Ginn and Company, 1970.

HEGENBERG, L. Definições. Termos teóricos e significado. São Paulo: Cultrix/EDUSP, 1974. cap. I - VII.

JAKOBOVITS, L. A. Second Language Learning and Transfer Theory: a Theoretical Assesment. Language Learning: A Journal of Applied Linguistics, v. 19, n. 1-2, p. 55-85, 1969.

JOHANSSON, S. The uses of error analysis and contrative analysis. English Language Teaching Journal, v. 29, n. 3, p. 246-53, 1975.

KATO, M. A semântica gerativa e o artigo definido. São Paulo: Ática, 1974. KEHDI, V. Morfemas de português. São Paulo: Ática,1990. (Série Princípios, 188).

LYONS, J. (Ed.). New horizons in linguistics. $3^{\text {rd }}$. ed. Great Britain: Penguin Books, 1972.

MACDONALD, C.; LEVESQUE, C. The ear of the others. Texts and discussions with Jacque Derrida. Otobiography, transference, translations. Montreal: University of Nebrasca Press, 1988.

MALMBERG, B. A Língua e o homem. São Paulo: Nórdica, 1976. cap. V.

MULLER, Ch. A Estatística lexical. O vocábulo, unidade do Léxico. In: Initiation à la statistique linguistique. Paris: Larousse, 1968. 
NASCIMENTO, E. L. Uma análise da polissomia de sistema, de universo de discurso e de discurso manifestado. In: X SEMINÁRIO DO CELLIP, 10., 1996, Londirna. Anais... 1996.

NIDA, E. A. Morphology. 2. ed. Ann Arbor: The University of Michigan Press, 1949.

POLITZER, R. L. The problem of the interference. In: Foreign language Learning. New Jersey: Prentice Hall, 1970.

PRETTI, D. Sociolingüística: os níveis de fala. São Paulo: Nacional, 1975.

QUIRK, R. A Grammar of contemporary english. London: Longmans, 1974.

RICHARD, J. C.; RODGES, T. Approach, design and procedure. TESOL Quartely, v. 16, n. 2, p. 153-168, 1982.

ROCHA LIMA, C. H. Gramática normativa da língua portuguesa. Rio de Janeiro: Briguiet, 1963.

SANDMANN, A. J. Formação de palavras no português brasileiro comtenporâneo. Curitiba: Scientia et Labor e Ícone, 1989.

SAVIGNON, S. Communicative competence: theory and classroom practice, reading. Mass, Addison: Wesley Publishing, 1983.

. Syntactic strutures. Paris: University/The Hague Mouton, 1966,

SWAN, M.; SMITH, B. Learner english. a teacher's guide to interference and other problems. Cambridge: Cambridge University Press, 1987.

VILELA, M. Estruturas léxicais do português. Coimbra: Almedina, 1979.

. Estudos de lexicologia do português. Coimbra: Almedina, 1994.

Cap. III.

- Tradução e análise contrastiva: Teoria e Aplicação. Lisboa :

Caminho, 1994.

WIDDOWSON, H. G. Teaching language as communication. Oxford: University Press, 1978.

WIERZBICHA, A. Semantics. Primes and universals. New York; Oxford: Oxford University Press, 1996. cap II e XII,

WHITMAN, L. R. Contrastive analysis: problems and procedures. Language Learning, v. 20, n. 2, p. 191-198, 1970. 


\section{TESES}

GALLEGO, M. R. A interlíngua na fala de adultos e jovens aprendizes da língua portuguesa. 2002. 177 f. Dissertação (Mestrado em Letras) Faculdade de Filosofia, Letras e Ciências Humanas, Universidade de São Paulo, São Paulo, 2002.

MACKEY, W. F. Language teaching analysis (Analyse de l'énseignement des langues). Thèse. - Faculté de Letres, Université de Génèbre. Londres: Longmans, 1965. n. 172.

MORAES FILHO, W. B. Uso denotativo das designações de cores em português e em inglês. 1995. Dissertação (Mestrado em Letras) - Faculdade de Filosofia, Letras e Ciências Humanas, Universidade de São Paulo, São Paulo,1995.

HARKOT, E. G. Emprego do computador no ensino da língua estrangeira inglês. 1990. Dissertação (Mestrado em Letras) - Faculdade de Filosofia, Letras e Ciências Humanas, Universidade de São Paulo, São Paulo, 1990 KINDERMANN, C. A. E. Polidez: uma análise contrastiva entre as línguas inglesa e portuguesa. 1993. Dissertação (Mestrado em Letras) - Faculdade de Filosofia, Letras e Ciências Humanas, Universidade de São Paulo, São Paulo, 1993.

TAVARES, J. G. Análise contrastiva das construções de classificadores em inglês e português. 1996. Dissertação (Mestrado em Letras) - Faculdade de Filosofia, Letras e Ciências Humanas, Universidade de São Paulo, São Paulo, 1996.

LAURO, I. C. A. Títulos de revistas: algumas estratégias de construção. um estudo contrastivo de revistas brasileiras e americanas. 1994. Dissertação (Mestrado em Letras) - - Faculdade de Filosofia, Letras e Ciências Humanas, Universidade de São Paulo, São Paulo, 1994. 


\section{ANEXOS}




\section{ANEXO A - Carta-convite}

A- Contato com estrangeiros para autorização da entrevista através de uma carta-padrão:

Este texto é dirigido a cada possível participante

Sra. Celina,

My MA research focuses upon problems native English speakers face while they try to get acquainted with Brazilian culture. Therefore, I would very much appreciate the opportunity of getting to know your experience regarding this issue.

Looking forward to hearing from you soon, I thank you in advance for your kind attention.

Sincerely.

Maria do Rosário

* My telephone number is 259-6913, but, never mind, I'll call you up later soon

Thank you,

Maria do Rosário 


\section{ANEXO B - Questionário de entrevista}

\section{Questionário}

O entrevistado estará livre para a escolha de somente algumas das perguntas.

1- Qual sua nacionalidade? (Em que país você nasceu?)

Qual é seu país de origem?

2- Qual é a nacionalidade de seus pais? (Onde nasceram seus pais?)

3- Qual é sua primeira língua? (Qual é a língua falada em sua casa, em família?)/(Qual é a língua ouvida e usada durante sua educação?)

4- Já conviveu ou aprendeu uma outra língua? (Fala outra língua?)

5- Fale sobre sua vida acadêmica - com quais áreas de conhecimento teve contato? (áreas de estudo ou trabalho).

6- Qual é sua profissão? Possui outra atividade?

7- Quando e por que veio para o Brasil? (Qual o tempo de permanência. Houve alguma interrupção?) (Há quanto tempo está no Brasil?)

8- Alguma coisa dificultou sua adaptação aqui no Brasil? Qual e por quê? E a comida? (What about the food?)

9- Pretende ficar? O que estimula (favorece) você (o Sr./Sra.) a permanecer no Brasil?

10- O que acha de mais interessante aqui no Brasil? ( $\mathrm{O}$ que mais desperta sua atenção?)

11- O que mais perturba (incomoda) você aqui? (O que não faz você se sentir à vontade no Brasil?)

12- Quais as vantagens e desvantagens de se viver no Brasil?)

13- Sente muita falta do seu país? Por quê?

- O que faz você (Sr./Sra.) sentir tanta falta?

- O que você faz para aliviar (diminuir) a saudade?

14- O que existe ou acontece no Brasil que faz você (Sr./Sra.) se lembrar de seu país? Cite alguma diferença e semelhança.

15- Onde costuma passar a maior parte do tempo?

16- De maneira geral, o que você costuma fazer (preencher) no seu tempo livre?

17- Na sua opinião, o que é mais valorizado pelo brasileiro? (O que o brasileiro mais valoriza?)

18- Cite um hábito brasileiro:

- engraçado

- estranho 
- diferente

- interessante (significativo)

- perigoso (ameaçador)

- elogioso

- crítico

19- Cite um governante que você admira, por quê?

- no seu país; depois, no Brasil.

20- Quais os desejos, ansiedades, necessidades e/ou obstáculos encontrados aqui no Brasil?

21- Qual mensagem, observação (reclamação ou elogio), sugestão ou conselho gostaria de dar ao brasileiro? (o que gostaria de dizer aos brasileiros?)

22- Qual a sugestão ou conselho você gostaria de dar a um estrangeiro que está chegando ao Brasil?

23- O que falta ao ensino de Inglês no Brasil?

24- Já estudou ou estuda Português? Se parou, por quê?

- O curso não atendeu(atendia) às suas necessidades de comunicação?

Ou seja,

- As informações não foram(eram) suficientes?

25- O que falta ao ensino de Português para falantes da Língua Inglesa?

26- Como e o que gostaria de aprender? Na sua opinião, o que um curso precisa ensinar para facilitar (tornar mais fácil) a aprendizagem e atender às necessidades e interesses de um estrangeiro que quer e precisa aprender Português?

- O que você sugere para conseguir se comunicar em Português? O que você espera de um curso de Língua Portuguesa para estrangeiros falantes da Língua Inglesa?

27- Qual a maior dificuldade de estrangeiro de Língua Inglesa ao aprender Português (quando está aprendendo Português?)

28- Quais as alternativas que você encontra para se comunicar quando the faltam as expressões e palavras adequadas em Português?

29- Você costuma ler? Tem hábito de ler? Que tipo de leitura você prefere?

30- Você gosta de alguma letra de música? Qual?

31- Por favor, sugira outras perguntas para serem incluídas na pesquisa.

Muito obrigada, Maria do Rosário 
Obs.: Farei pessoalmente as entrevistas no local, dia e hora sugeridos pela senhora: é um objetivo respeitar rigorosamente a disponibilidade dos entrevistados.

M.R.

Procuramos criar questões que estimulassem os entrevistados a fornecerem informações, emitir opiniões pertinentes à organização de pontos básicos como: deficiências didático-pedagógicas, dificuldades e inadequações lingüísticas que embasaram nosso projeto de ensino, garantindo a ele um cunho mais objetivo e funcional.

O material coletado foi transcrito e organizado de maneira formal e ordenada - um "corpus", que acabou sofrendo um recorte referente ao "subcorpos" (tabelas de correspondências). 
ANEXO - C - Transcrição das entrevistas

\section{1 - Grupo dos adultos}

\section{1 - ANDREW DEAN - DIPLOMATA}

Meu nome é Andrew Dean de Consulado Britânico. Eu já moro São Paulo quinze meses. Meu descendência é inglês, $100 \%$ inglês. Ambos minha mãe, meu pai são ingleses de norte de Inglaterra e meu pai de Londres.

Durante minha caria - a diplomata eu já aprendi três línguas estrangeiras: alemão, vietnamita, agora Português. Infelizmente essas três línguas têm um número conexões inter - intra nouns. Eu não estou especialista de línguas, mas nosso recado é aprender, então eu aprendo.

Minha formação foi na Universidade [...] na área de Administração das Empresas. No mês de maio 97, eu cheguei no Brasil, em São Paulo, depois de mais ou menos seis meses de estudante de Português em Londres e três semanas em Belo Horizonte.

Nós no Consulado não têm muitos dificuldades entra na vida no Brasil porque as funcionários de Consulado ajudam com o residência, uma casa; podemos comprar um carro, dois carros sem impostos, também porque nosso ministério ajuda com esses aulas de língua, mas existe muitos dificuldades, como nós somos de centro/isento, então não tem uma norma 6 [...] então a burocracia no Brasil muito difícil porque em São Paulo não existe muitos diplomatas. Em Brasília é diferente: o sistema de vida para diplomatas em Brasília é mais fácil porque a Itamarati organizam todos ns city-cidade, a prefeitura. Gentes como Estado de São Paulo não fizi nada especial para nós. Colabora sim mas não para vida privado. Colabora as coisas eficiais, apenas eficiais.

Então eu vou viver ou morar em São Paulo até três anos normalmente. Normalmente nossa caria tem períodos de 2 até 4 anos no país estrangeiro, mas no Brasil normalmente é três anos. É que eu gosto muito de cultura do Brasil: música bastante; é um pais muito interessante porque uma país de primeiro mundo [...] a gente está num país que é quarto mundo. Em São Paulo as pessoas vivem juntos ao lado do outro. Normalmente, claro nós moremos na área de 1 mundo como os [...] trânsito, hoteis, as conexões com pessoas de classe alta e classe média, mas é impossível não encontrar as pessoses pobre nas ruas do Brasil.

(O que mais o perturba?)

Acho que é uma destes - o medo de crime. Felizmente eu e minha família ainda não sufre algumas turmas de violência, mas eu vi uma vez 
uma solto na rua - o comercial de estrangeiros assuntos roubos possou uma dificuldade.

Gentes com - o fato de que poucos brasileiros da área do comércio conhece a língua inglês bem. Para mim não é muito problema: eu conseguio entender; para os membros da família é mais difícil.

(vantagens)

Claro, o clima é melhor do que na Inglaterra: gente tem mais paz; são mais felizes. Só eu estivesse não cassado (casado) esse [...] lindas mulheres [...] muito fantástico.

Mas realmente nós temos um trabalho muito sérios aqui para desenvolver o área do comércio entre os dois paises.

Um vantagem grande - o entusiasmo dos brasileiros conhece outros países para fazer mais ligações como fazem outros partes incluindo a Inglaterra.

Um desvantagem - poucos brasileiros conhece a Inglaterra bem como a Itália, os EEUU, mas esso é uma parte de Consulado como ter mais conhecimento da Inglaterra.

Eu tinha com minha mulher no supermercado Brasil mais ou menos todas os coisas a gente precisa, mas eu senti uma falta dos coisas de comida como [...] café da manhã, outros coisas. Uma falta de pequenas coisinhas, mas aqui no Brasil temo frutas tropicais, outras [...] bons; para mim acho que muitos coisas falta, além de teatro britâni [...] inglês; os filmes, por exemplo, em São Paulo normalmente igual ao original [...] por exemplo, isso [...] bom.

Existe muitas semelhanças entre a Inglaterra e o Brasil, especificamente em São Paulo e Londres. Os duas cidades são grande demais: tem muitos transtornos do trânsito, de áreas de violência, bairros pobres, bairros ricos. Os motoristas de taxi aqui em São Paulo não conhece as ruas de São Paulo - um problema, mas justo como os motoristas de taxi em Londres, algumas vezes tem dificuldades também. São muitos semelhanças.

As diferenças que tem mais normalmente na área de propriedade público como os calçados os buracos no rua, os qualidade de transporte coletivo; metrô é bom, os ônibus infelizmente ruins - é preciso fazer uma melhoramento dentro desses áreas do público.

A maior parte de meu tempo passo no trabalho. Outros áreas além do trabalho: tenho um filho. Nós gostamos aproveitar os parques como Ibirapuera [...] Sampaio - esse coisas de crianças. Mas para as crianças? Que não conhece Português bem é pouco [...] é difícil entender a criança como as crianças brasileiros - mas esso coisas o mundo inteiro.

Os brasileiros - [...] meu filho atende a Escola Saint Paul, a escola britânica nos jardins. Os pais dos crianças brasileiros lá são de classe 
alta. Acho que eles valorizam os condições [...] ambas no Brasil estes estrangeiros também [...] os carros, as casas, prédios.

E que os brasileiros geralmente são pessoas honestos, pessoas de gran humor. Acho, mas é difícil pra mim entrar na coração da alma brasileira.

A minha vida aqui no Consulado uma ilha de inglês; em casa também, na escola mais ou menos. Eu tenho amigos brasileiros, claro que os brasileiros que conhece os países estrangeiros, então [...]

(Algo crítico)

Normalmente não. Eu gosto dos brasileiros.

Felizmente aqui no São Paulo nós somos especialistas na área do comércio, não na área política, mas o Fernando Henrique parece como um homem honesto que quer fazer uma trabalho bom para alcançar o país do Brasil. Acho que muitos outros políticos façam o mesmo, mas claro porque o Brasil tem um sistema de governo muito complexo - junto com o nível federal, estadual, municipal. Existem políticos demais, por exemplo, Câmara dos deputados, os congressos, a gente com todos os vinte e sete Estados. Então parece a Austrália. A Austrália tem uma população de dezessete milhões, talvez dezoito milhões; também tem esse sistema estadual (federal), estadual, municipal. Gastam muito dinheiro a administração deste tipo de arranja. Nosso sistema na Inglaterra foi mais simples como um governo nacional e um governos municipal. Mas o político de nosso governo e a muitos partes governo da Escócia, o governo do país de Gales, grande parte da Inglaterra [...] Acho que nós, no futuro, nós vamos ter um sistema pouco mais semelhante como no Brasil.

[...] (seus desejos)

Mas, eu ainda não ler todas as perguntas. Meus desejos aqui são simples: trabalho sem disturbance, sem dificuldades, juntos com viver sem dificuldades.

(Problema)

A burocracia do Brasil. Recentemente Distrito Federal dificulta nosso trabalho o coisas da alfândega, e com as coisas simples, parece simples, como expectar carro, expectar things pessoais. Nós não temos isto podido interces [...] nesta área.

A étima aqui [...] nós temos poder para alcançar o Distrito Federal liberar nossos bens rapidamente, mas demora muito na área de importação e exportação dos bens pessoais. Eu não falo sobre as coisas comerciais. É muito mais difícil do que nossos na Inglaterra. Então renovar esta burocracia, uma parte desta burocracia para seletar a educação de estrangeiros no Brasil. Os homens de negócio estrangeiro passam muito tempo achando uma casa, carro, funcionários, escritório, coisas de taxas de impostos. Este custo Brasil parece 
atrasado, eu acho [...] procura trabalho nas outros países para evitar essas dificuldades. Eu não posso quantificar essas coisas mas todo mundo sabe da burocracia Brasil é uma lião.

Este coisa de Ensino Inglês no Brasil é interessante porque o Cultura Inglesa, outras escolas de língua são cheio dos estudantes, mas eu acho que muitos destes estudantes não continuam com este curso. Depois do curso, têm um certificado, esquece todos, possivelmente porque até agora não existe um médio, por exemplo, a coisas internacionais para eles trabalham e usam esta língua. Então o país do Brasil perder estes students de línguas. A falta é na área comum, nas ruas, como nos cafés, nos restaurantes, em tudos detais na área turístico, porque estes únicos estam interessados, normalmente estam ensinando Inglês, curiosamente os bancos, esses [...] coisas de seguro, outro tanto [...] conhecimento de Inglês. Acho que nos próximos anos esta situação está melhor, mas agora uma das áreas onde Inglês é conhecido, outras áreas [...]

Eu não conheço estes cursos em detalhes, mas essas escolas de comunicações - Quick English - de language usando de Cultura Inglesa têm muitas internacional. O problema é na aula de alunos: um pouco de modo, este [...] verbos - o sucesso aulas de Inglês [...] , para encontrato outros alunos, essa é uma coisa social, não uma coisa que [...] de entender.

Eu estudei a português Londres com uma professora brasileira, que mora em Londres. Eu parei de estudar quando passa uma prova, uma coisa de nível intermediário. É suficiente para comunicar esses pessoas área comercial, mas é uma aula de Português para ajuda o trabalho. Não Português para ajuda a vida social. Então na área de bares, restaurantes encontra outras pessoas fora da área do trabalho (ele diz) eu não entendo estas palavras - não, não - não sei nada.

Nosso escritório, o governo britânico pagou para mim aprender para trabalhar até fazer um vida social. $\mathrm{Na}$ Inglaterra exclusivamente, Português não é uma língua onde é fácil encontrar aulas. Normalmente na Inglaterra os colégios, as escolas ensina Francês, Alemão, Espanhol, possivelmente Italiano, porque (Português) normalmente não.

Português do Portugal e Português do Brasil é mais ou menos iguais.

Normalmente os brasileiros são bons, porque o Portugal do Brasil o povo aqui fala devagar normalmente e também eles querem os estrangeiros entender. Não é como os franceses, Paris, por exemplo, sem conhecimento cem por cento, os franceses não querem comunicar nada. No Brasil, os brasileiros ajudam. Mas a maioria dos estrangeiros uma dividio que cinqüenta por cento Inglês, cinqüenta por cento Português - uma conversa pouco estranha, mas usando as duas línguas 
$[\ldots]$

A maior dificuldade para mim da Língua é uma gramática. Mesmo que Português é uma língua tan lógica, a gramática é difícil - ter mais tipos de presente, futuro [...] mas eu pego.

Então [...]

(O que gosta de ler)

Tudos. Eu normalmente leio o jornal, a Folha de São Paulo, a revista Veja. Às vezes eu tenho um livro muito engraçado: "A comédia do Vida Privada" - muito engraçado. 


\section{2 - VICE- CÔNSUL COMERCIAL}

(Conhecimento de Línguas)

Si. Já aprendi Espanhol, Árabe, Holandês e agora Português.

Para meu [...] mim é mais importante o interesse pessoal. Eu aprendi Árabe - não encontrei nenhuma dificuldade porque nós temos [...] sei que é uma língua difícil. Agora Espanhol e Português era para mim fácil; eu também gostei muito. Só Holandês que foi difícil, eu não gosto esse tipo de língua germânica.

(Seus pais)

Inglês

(Dificuldades no Brasil)

Eu só cheguei em junho. A mais difícil é o burocracia, especialmente do lado de alfândega porque todas minhas coisas pessoais estar esperando ser liberados ainda em Santos. Eu não vi essas coisas desde setembro do ano passado [...] demora muito tempo a burocracia aqui; só para pedir aduana liberar as coisas [...] finalmente chegou esse dia, mas aduana está entraso. Estou aqui dois meses num apartamento vazio: não tem móveis, não tem coisas pessoais; eu fico esperando as coisas preocupado também. Não dá para assimilar como um trabalho o resto aqui. Isso é só um exemplo. Acho que a burocracia aqui é [...] todo é muito devagar; todo anda muito devagar para obter um documento, para abrir conta bancária, para fazer qualquer coisa. Falando pessoalmente, eu sou piloto particular; piloto avião por lazer, tenho um brevê/brevet holandês e um brevê inglês. Dá para voar em todo o parte do mundo fora do Brasil. Aqui ainda estou esperando. Muito obstáculo neste instante.

Tem que reformar a cultura aqui, não só as leis, mas a cultura inteiro. Precisa uma revolução: cultura-política [...]

(Dificuldade em Português)

Para mim foi esse coisa de todas palavras Português têm muito diferente sentido, então um vocabulário acho que não é tão grande quanto o vocabulário Inglês ou de outro língua que eu conhece, mas tem poucas palavras, mas saber como usar e qual entender o que nós estão falando, usando um palavra que é num contexto tem um sentido, num outro sentido (contexto) tem outro sentido totalmente diferentes e isso es muito diferente - pode ser para atrapalhar muito. Eu não encontrê isso tanto com Espanhol, mais com Português.

(Gosta de ler-?)

Gosto. Os escritores favoritos são Gabriel Garcia Marquês e Graham Greene).

(Sobre o Brasil)

Eu tem muito que eu gosto de Brasil; eu realmente quis vir aqui. 
Eu [...] tem o seguinte que tem muito que para gostar, pode ser um gosto muito bom, mas tem que ter paciência, especialmente no início com tudo isso de burocracia. Tem que manter um sentido de humor, paciência que todo, todo se resolve. Eu com experiência de morar num país árabe, onde também tem esse problema - de burocracia, paciência, mas acho [...] aqui é pior [...] infelizmente.

(Para continuar a entrevista)

A menos que queira falar perguntando [...]

(Sobre sua permanência no Brasil)

Eu gostaria, mas com meu trabalho só posso ficar aqui dois anos; é um posto diplomático - terminado o tempo, depois de três anos, quatro anos, tenho de ir para outro país, mas eu gostaria de ficar.

(Se algo Ihe incomoda)

Realmente não porque eu gosto de se meter num país, comer a comida deles, se adaptar, então isso de não poder comprar um tipo de comida não me interessa, não me incomoda. Só esse problema de [...] quando chega aqui, toda essa coisa de burocracia para obter permissão de dirigir, de pilotar, de ter as coisas da alfândega. Acho que depois será muito melhor.

(Sua profissão)

Sou diplomata. Sou vice-cônsul de Comercial e Informatíon relações com a MEDIA.

Tenho dois filhos. Eles estam na Faculdade na Inglaterra.

(Permissão para continuar a entrevista)

Se você perguntar mais um pergunta [...]

(Vida acadêmica)

Bom, eu segui um caminho acadêmico um pouco menos convencional e depois do Colégio, em Academia Naval. Fiquei seis anos na Marinha Guerra prestando serviço.

(Onde passa a maior parte do tempo?)

Infelizmente temos que passar maior parte do tempo trabalhando. Ah! Quando finalmente eu tenho brevê, será voar pilotando.

Eu não gosto muito de praia. Eu prefero muito as montanhas, de ficar voando, conhecendo lugar desde (from) o ar.

(Conhece muitos lugares?)

Conhece muitos. Vou dizer quais: fui a Manaus, Belém, São Luís do Maranhão, Fortaleza, Recife, Salvador, Brasília, Rio de Janeiro, São Paulo, Foz do Iguaçu, Florianópolis [...] só.

Só que eu acho São Paulo é muito diferente das outras cidades que eu conhece do Brasil. Acho que São Paulo não é tipicamente Brasil. Eu acho que Rio de Janeiro é Brasil. Florianópolis é outro Brasil e as cidades no resto - de norte, acho que são cidades do Brasil. Acho que São Paulo, brasileiros completamente diferente. Eu gosto mais do norte: 
de Belém e Manaus, das cidades que já conhece.

(Invasão da língua inglesa no Brasil)

Eu não ouço muito pessoas falando Inglês - muito pouco.

Iso só acontece em outros países também. Estam aprendendo as palavras do momento, da cultura mais dominante, que é dos Estados Unidos através dos filmes, das culturas moderna dos Estados Unidos(Sobre Graham Greene)

Quer dizer [...] Eu não me preparei para das resposta uma pergunta assim. Eu gosto este tipo de linha porque dá para pensar - não é menos [...] sempre é mais profunda.

(Filme interessante)

Tem muito. Nem pensei ante da entrevista.

(Quer responder mais?) (Quer outras perguntas??) trabalho.

Infelizmente não tenho muito mais tempo. Estou com muito 


\section{3 - WINDY JORDAN - DIRETORA DO CONSELHO BRITÂNICO}

Eu tenho um processo da alfândega muito complicada. Durante três anos eu tinha bastante processos, mas cada processo estam pequeninho diferência, mas estam diferência significar, muito significar... significante. Você não tem uma sistema regular. $E$ talvez as pessoas do Alfândega mudou também. Você tem uma relação muito simpático com uma funcionário da aeroporto. Você tem uma re(ú)nião bem simpático. "Deixe-me ver, a pessoa não está" um pessoa diferente. Uma burocracia dos instituições - geralmente as pessoas está muito simpático, mas o processo [...] e também o sistema político, porque na Inglaterra quando o governo mudar, os serviços civilia fica, mas aqui todas as pessoas dos funcionários do governo mudam também; p. ex. agora eu estou falando com uma museum aqui. A diretora depois dos eleições vai sair. Nós não conhemos a próxima diretora. Eu estou falando com uma [...] com pessoa com certeza não vai estar lá durante noventa e nove. Eu estou picando/aplicando os projetos dos Artes agora, mas realmente eu não espero o projeto vai mudar, mas talvez nós não temos certeza. Esta é uma [...] Eu tenho [...] e estou nervoso sobre o programa, porque eu preciso fazer os contratos na Inglaterra agora com [...] o ano que vem.

Eu estou [...] eu acho que o causa esta contratos, mas realmente [...] geralmente tudos está tranqüilo, mas o processo talvez [...] não está confirmado. Mas, geralmente nós temos um relação com muito sucesso, mas é tan (tem um) pequenho parte - mas [...] de novo é significante.

Eu cheguei depois do início do plano real. Eu não tinha as problemas com inflação é [...] realmente eu acho que está muito dific(í)l; eu não tenho problemas com mia moeda [...] not/nada. Sim, sim, noventa e cinco. O plano real foi durante noventa e quatro; eu não tenho experiência dos outras [...]

Eu acho que os grupos do políticos têm as campeonatos muito professional, mas eu acho que é como o sistema das Estados Unidos e tanbém a diferência é muito interessante porque na Inglaterra nós temos os partidos e as pessoas da Inglaterra têm uma [...] os policials [...] pólices, "parties", políticas; as pessoas não está mais importante, eu acho que aqui a/os pessoa é muito importante, p. ex. Avenida Rebouças está aqui; aí nos temos o sedes dos partidos; eles têm "outdoors" da pessoa, "outdoors" [...] os caminhoneiros, cabos/carros com os "logotipos", mas realmente eu não conheço os políticos das partidos; eu conheço as pessoas. Na Inglaterra nós temos uma base muito diferente mas, eu acho que a maior/maioria das eventos no Brasil tem sem violência, sem [...] com alegria. Eu acho que a cultura aqui está muito relaxada [...] relaxado. Eu acho que a sistema [...] e talvez você tem uma 
sistema diferente com [...]. Você tem um presidente [...]

Brasil está [...] Brasil é uma República; Inglaterra está [...] é Monarquia. Nós temos os diferências de Constituição [...] interessante.

Quatro ou cinco anos eu acho que eu vou ficar aqui. Meu coração quer, mas realmente o Conselho Britânico tem uma policia do mudar as pessoas depois de 4 ou 5 anos. E também realmente eu preciso dum promoção. Eu acho que geralmente não é possível ficar com/uma vez até uma promoção. Eu acho que eu vou voltar para a Inglaterra durante noventa e nove, outra país, mas não é... eu estou muito complicada (seu marido).

Não, não, não, ele trabalha com teatro na Estados Unidos, Canadá por quatro e seis meses cada ano. Quando ele está aqui, ele tem os amigos, mas ele não tem uma trabalho aqui.

Sim, com certeza: ele gosta do sol, é [...] do ambiente, o litoral. Com certeza, o litoral de São Paulo é linda. Realmente nós temos uma vida cultural muito bom aqui; eu tenho os convites para filmes, festival de filmes, os concertos, você tem cultura artística e também nós temos o mundo diplomático; nós temos os eventos com os vips da Inglaterra; eu tenho oito, nove eventos do Conselho cada ano. Nós temos uma vida muito ranimada/reanimada realmente eu tenho uma vida muito confortada aqui; eu tenho uma faxineira em casa; o tempo com certeza, o sol; eu gosto bem dos pessoas do brasileiro e também o país é lindo; você tem litoral muito lindo, os cidades fenominal, o Amazona natural, o mundo natural.

Geralmente eu visitei [...] eu visitou as cidades, mas eu conheço que eu tive Belo Horizonte, Rio, Manaus, Recife, Fortaleza, Brasília, mas geralmente as cidades, mas nós ficamos por dois ou três dias em Paraíba, o e Rio Grande do Norte, Campos de Jordão, (gostou ?) sim, gosto bem - como Inglaterra.

Às vezes eu tenho decepção/frustação com os telecomunicações, com certeza; o "internet" porque em moro em Higienópolis e agora nós temos uma sistema de telefonar muito bom, mas, por exemplo, quanto meu marido trabalho em Londres, nós tínhamos três telefones: uma linha do fax, uma linha do telefone, e uma celular e não foi caro, uma linha segunda em casa é [...] realmente cinqüenta dollares; aqui é três mil dollares; realmente eu acho que a Economia do Brasil está sofrendo pelos telecomunicações, eu tenho certeza; e, estou confiança [...] porque os motoristas do Brasil também é muito perigoso; os caminhões também é muito perigoso. Eu não dirijo aqui. Em Londres eu tenho um carro, com certeza, mas aqui os ônibus ser [...] iso, trânsito é assim [...] você não tem no sistema do transportiva público, mas realmente eu moro em Londres: nós temos uma sistema muito sofisticado, do maior do mundo: não tem uma sistema só [...] por comparação não está justa 
às vezes porque o Inglaterra tem trens pequenhos, temos uma rede dos trens, rede dos ônibuses, mas Inglaterra está o mesma tamanho do São Paulo. Geralmente eu fiquei vontade aqui.

Realmente p(é)quenho; talvez os alimentações, mas eu volto para a Inglaterra duas vezes para o ano; eu levo chá Inglês, com certeza: eu preciso chá Inglês. $\mathrm{E}$ também os livros, às vezes, os livros, mas nós temos as jornais da Inglaterra no Escritório. Eu tinha [...] Eu tenho as revistas, dois ou três revistas da Inglaterra. Às vezes eu tenho saudades do [...] mudar os tempos: mudar [...] nós temos quatro [...] mudar (estações) e, também, por exemplo, o ano acadêmico na Inglaterra é diferêncie daqui: durante setembro as escolas volt(á)m e os arv(ó)res está [...] vivem caiô e o ambiente está uma início do escola - uma ambiente do poucas, mas aqui está uma [...] você tem dois semestres: durante setembro nós estamos tendo primavera.

Não (conselho) ficar demais formal. Eu acho que, por exemplo, o Conselho está uma Instituição com um cultura mais formal, mais formação [...] . os sistemas do mundo e eu acho que a Conselho tem [...] nós preferimos tem contratos, papel, mas aqui quando uma pessoa de [...] é possível ter uma concorda verbal [...] fica bobage [...] não tem preocupação, talvez aprenda uma [...] a História do Brasil é muito interessante. As sistema, você tem agora está uma resultado do História recente. Eu acho que é muito interessante se divertir [...]

A litoral (tempo quando não está trabalhando) - quando eu tenha a oportunidade, eu viajar para o litoral, porque [...] sim Juqueí, Barra do Uma, nós temos as amigos lá [...] Anglo-Brasileiros.

Realmente a família está [...] o marido está Inglês, a esposa está é brasileira.

Os filmes, também, porque eu acho que Brasil tem uma seleção dos filmes muito bom (filme brasileiro?). Às vezes, com certeza, mas geralmente eu vi os filmes populares, mas não é esta verdade, porque, por exemplo, São Paulo tem o festa do filmes jurídica muito interessante. Cine-Sesc tem uma seleção dos filmes, dos artes. Você tem Vídeo-Brasil, Festival dos Curtas Metragens. Eu gosto bem do Mis. A MIS tem uma programação [...]

Eu acho que Francisco Befforte, o ministério da Cultura, [...] eu acho que ele tinha uma trabalho muito interessante, [...] com certeza. Eu acho que os movimentos populares é muito interessante também, os/alguns movimentos dos sem-terras. Eu conheço o movimento tem problemas com certeza; tem um mistura da pessoas, mas em geral eu acho que os povos têm os/uns idéias muito interessante, com certeza. Eu acho que é feitichi estão liderando/idéia do mundo e tem uma lugar na mesa do mundo.

Tony Blair - Eu acho que os diplomáticos não está tramitado para 
com os coletivo em detalhes, mas o Conselho Britânico está [...] mas eu acho que umas duas dos políticos do diretas têm idéias bom, eu acho que mas realmente eu prefero o "[...] party", mas agora é muito dific(í)! porque todos os políticos têm [...] o [...] centro, talvez direto do centro, esquerda de centro, mas os políticos do mundo têm o mesmo situação. E Clinton, por exemplo, ele é o democrático, mas ele precisa os pessoas "Republicans" (Ensino antes de vir para o Brasil) do - da Foi/Fui herado também.

(Programa de Ensino formal e informal conviver com a família). Eu acho que você precisa os dois. Eu preciso de explicar para vocês. Quando eu cheguei no Brasil, eu não tinha bastante tempo aprender Português. Eu quis com certeza, mas eu tinha uma mês somente. Geralmente as pessoas do Conselho têm uma programa do Português bom, Francês, o Espanhol, antes do viajando e depois da [...] (acabou a fita) [...] bem vai chegar, você tem outro curso. Realmente a família do Rio (família Grande??) [...] nós aprendemos como vivar no Brasil. Dois filhos: filha, filho; mas dentro o mesmo prédio e uma da esposa, so [...] depois da jantar, a família, a uma fica com televisão, com o novela das oito. Uma vizinha, também; nós tínhamos um grande grupo, mas [...] nós fomos pra terra da rua, supermercado, aeroporto.

Eu li realmente os palavras (como ia aprendendo?) dos anúncios; realmente eu tinho umas ou duas disastres, com certeza, no supermercado com cheque primeiro vez - a línea. Foi ra(í)va - porque eu preenche meu cheque errado. A menina do supermercado não entende eu sou inglesa e não tenho um sistema de cheque [...] mas você precisa continuar [...]

Com um táxi (outro episódio) porque [...] tem diferência da Inglaterra. Em Londres nós temos um sistema do táxi [...] motoristas do táxi têm bem conhecimento da Londres. Aqui uma pessoa com táxi não tem nada, por exemplo, durante o copa do mundo eu fiquei aqui mais tarde uma dia. Eu peguei um táxi e: eu moro perto de Pacaembu - de Estado de Pacaembu - por favor, o rua Conselheiro Brotero o Higienópolis. Quem? Perto do Hospital do Samaritano. O mundo conheço. Quem? Pacaembu? Você conhece o Estado do Futebol? Não? Eu acho que ele cheguei [...] chegou do entero - enterior do São Paulo. Eu não saber contar o motorista do táxi meu endereço [...] mas [...] os pequeños desastres, com certeza. Eu senti muito estúpido. E também outra exemplo: pra aeroporto quando meu [...] minha primeira vez com um VIP. Agora Guarulhos estam bem organizado. Eles tem bastante informações mas três anos passado eles não têm uma sistema bem. Quando eu cheguei no aeroporto, o vôo não foi anunciado; eu não sube sobre entra aero. Realmente eu tinha um motorista nova também. Nós fomos pra aeroporto sabendo nado conjunto. Meu VIP foi muito 
atrasado; ele perdia os/as [...] malas; este uma grande problema. Onde estava a bagagem?

Miami. Nós nunca procurar (never found). Mas Varig - a linha do avião pegou bastante dollares para VIP. Esta um história muito interessante porque eu fiquei aqui seis meses mais ou menos. Meu VIP, senhor John, chegou aqui atrasado com conferência sem os roupas formals. Nós tínhamos uma re(ú)niõn com o governador do Estado de São Paulo, poxa!! [...] Por favor, eu [...] não é possível para mim encontrar o governo do Estado com os roupas informais. Nós fomos pra Iguatemi. E também ele fuê uma homem muito mais alto com ombres [...] eles não estam uma tamanho brasileiro, com certeza. Nós fomos pra Iguatemi; uma loja alto niv(é)l. Felizmente o menino da loja falou um pouco Inglês e nós realmente nós tem bem sucesso com os roupas formal, meo, gravatos, camisetas. O! experiência! Meu nome é Sra. Jordão [...] A história do nome está muito interessante. Como os cruzadas foram pra rio Jordão e travessa - eles tinha o permissão do rei de Fitzgerald - trocar a nome da Jordão. A nome está do meu marido porque na Inglaterra nós temos o tradição - mudando sua nome com você tem um casamento.

Meu nome é Coss Também do [...] as vezes a nome Gordan tem uma outra letra $\mathrm{J}$ - e está Jordan, mas eu prefero a história do rei Ricard.

Eu sou a diretor ajudar. Eu tenho a responsabilidade das Artes do Conselho no Brasil. Nós temos quatro escritórios no Brasil: Brasília, Recife, Rio e São Paulo e cada escritório tem uma responsabilidade única. Rio tem uma/a responsabilidade dos assuntos educação, informações. Recife tem a responsabilidade dos projetos com a meio ambiente. Realmente eu tenho os projetos do meio-ambiente aqui, mas eles tem os exportis; Brasília tem a responsabilidade do todos os mundo diplomático.

Três anos e meia. Até cinco horas - eu acho que [...] cinco anos, desculpe. Geralmente a Conselho Britânico, os funcionários do Conselho ficar em peís por até cinco horas. Eu gostaria ficar com certeza, mas eu preciso dum promoção. Geralmente não é possível ter um promoção dentro o país. E talvez eu vou voltar pra Inglaterra por três anos ou talvez um outro país (sua formação em Artes?).

Sim. Teatro. Eu trabalhei por um mês em Moscou. Eu aprendi a língua da França na escola. Fala bem Francês?). Eu acho que é mesmo niv(é)l do meu Português realmente. Eu tinha a responsabilidade dos país do América Latina. Eu visitei Brasil durante o ano noventa e um. (Fiquei) três semanas somente - período pequeno. Sim (pediu para vir?), porque eu gostei bem do Brasil; quando eu ouvi a [...] sobre o trabalho aqui eu falei com meu chefe: Por favor, eu gostaria ter um trabalho no 
Brasil, com certeza.

(Aprendizagem da Língua Portuguesa) Aprendeu no Rio? Sim. Meu marido e eu fomos pra Rio por três semanas; nós ficamos com uma família no Rio. Esta [...] foi a família da professora. Nós ficar com o apartamento deles. Ela foi uma professora bem, com certeza, mas eu acho que o situação foi tudos dific(í)l porque quando vocêm fale Português o dia com uma pessoa durante a noite é muito dific(í)l, até jantar nós fomos muito descansada; nós não tínhamos outro palavras e também nós aprendemos só gramática, sem vocabulário. Realmente eu acho que uma pessoa que vem aqui precisa o vocabulário porque as pessoas do Brasil estão muito simpático com estrangeiros. Eu acho que se você tem o vocabulário bem, a gramática, com certeza, é necessário, mas a início eu acho que o vocabulário é melhor.

(A habilidade com mais dificuldade? Listening?) Sim. Eu tinha uma problema com compreensão. Todos os professoras me diz: Fala Português, fala português! Você vai aprender pelo falando, mas não é verdade. Eu acho que você precisa escutar porque o radio, por exemplo, agora eu posso entendo as notícias. Eldorado, por exemplo, tem os destaques às sete horas. Eu ouça, destaques: Manaus paaparaparaparaparaparapara. Não é possível aprender, mas durante o primeiro ano eu tentei bem escutar? Português.

(Depois dessa família, voltou a estudar Português?). Ah! Um pequeño. Eu tinha um professora por duas horas cada semana. Mas eu acho que não está bastante e também ele quis [...] er [...] ensaio gramática; ele tem uma obsessão com o subjuntivo; ele realmente obsessão. Esta parte do gramática do Português é mais dific(í)l por as pessoas que fala Inglês porque nós não temos uma estrutura ou forma, mas eu acho que eu aprende Português da rua com os lojas, os motoristas do táxi, os meninos no escritório. Mas [...] realmente eu gosto fala Português, mas it's

(Como se sentiu na entrevista?) Ah! Eu não tenho/tem certeza. Eu estou nervioso você vai usar por uma outra assunto.

Realmente eu estou contente por falar com você, porque eu fui (I was very unbappy) o primeiro ano aqui. Realmente eu quiser voltar pra Inglaterra; eu tinha uma sentido isolação; eu me sinto estúpido; eu [...] foi muito dific(í)I ter uma re(ú)nião fácil. And so/Esso [...] Realmente I trust you.

Realmente, em confiança: eu acho que os professoras de Português [...] está muito difícil procurar uma professor bem de Português; geralmente eles estam professoras da Inglês e eles gostaria falar Inglês. É muito dific(í)l, muito dific(î)l. E também eu tinha uma professor que aprendo Inglês na Estados Unidos e [...] as línguas têm diferências significante. Eu acho que de novo eu vou fazer, eu deve 
fazer uma procuração muitos detalhes, com muitos detalhes com professor porque eu acertei/aceitei uma pessoa que fala [...] que falo o Inglês bem, mas eu acho que é melhor procurar um pessoa que tem as habilidades da línguas. Uma outro observação: as pessoas que têm um talento das línguas não está as pessoas melhores ensaia língua. Eu acho que se eu tinha o tempo, eu gostaria escrever uma livra: "Language for clutses" - Como ensinar/aprender uma língua se você não tem talento da língua? Porque esta o problema: os pessoas que têm o talento da língua não tem o não percebem o potencial, a capacidade individual/ não consegue perceber a limitação de cada um como eu [...] imaginação por pessoas como eu. Eu não estou muito ruim da línguas, com certeza, mas nem eu não tenho um conhecimento/talento bem da língua. Eu acho que eu perdi uma ano, porque eu não tinha uma técnica/sistema. Realmente as aulas não têm [...] não tinha um tema; eu sugeria/falei com o professor: hoje eu acho que nós vamos falar com o vocabulário do aeroporto, o vocabulário dos carros. Mas, eu [...] eu tinho, tinha a responsabilidade por o desenvolvimento das aulas. (It was terrible! Awful!) Porque você precisa [...] por exemplo, você gostaria aprender Inglês, você vai ficar lá uns seis meses; eu acho que agora eu deve dar os aulas pra você porque meu experiência aprendendo Português. Eu acho que também aprendendo uma língua está muito psicol(ô)gia, muito [...] Uma outra "fact" da [...] Quando eu cheguei aqui, eu não sou chefe bem, mas eu tenho uma quadro, um quadro [...] eles têm uma "advantage" avantage porque as pessoas da escritório fala Inglês bem, fala Português bem. Eu precisei ter uma autoridade. Se você não fala Português bem você não tem autoridade bem, então eu falo/ei(?) Inglês porque eu precisei ter uma posição do chefe. Talvez [...] é muito dific(í)l admitir: você tem um língua fraca ou você não tem conhecimento com sua quadra. Eu me lembro o processo agora. Mas [...] e talvez eu me penso: ah! Eu não tenho talento dos línguas, eu não tenho talento dos vivar estrangeiro, mas agora realmente eu estou muito contente aqui, mas, o primeiro ano foi dific(í)l, foi dific(í)l. (Conselho para professor para estrangeiro).

Nós não temos uma pessoa regular e também porque eu tinha dois colegos; ele falam Português muito bom. Ele não tinha [...] sim, nós temos [...] o escritório tinha três pessoas Inglês, Ingleses, mas os dois outros falam Português muito bom. So, de novo eles não tinha um percepção; nós não tínhamos cultura. Se eu vou ir pra outra país, agora eu vou desenvolver uma sistema muito bom. 


\section{2 - Grupo dos jovens}

\section{1 - BENJAMIM - Texas (EE.UU)}

\section{Benjamim [...] (Sua descendência)}

Boa pergunta. De verdade não sei exatamente de onde sou. Eu acho que eu tengo sangre de Irlanda, da Scotland também, não sei a palavra para Scotland, mas um pouco de de [...] um pouco britânica de todas maneiras e acho um pouco alemã também e talvez, talvez cinco por cento algo assi de índio americano, mas não sê com certeza; eu tengo que perguntar para miu avô porque ele já fiz este pesquisa. E a origem de meu nome também eu seu que "Philips" quer [...] significa "lover of horses" ou uma persoa/pessoa que adora os cavalos, mas eu sei que Benjamim quer dizer em [...] sus raízes lá tem eu acho que "little king" que é rei pequeno, algo assim, mas sei não [...] não falamos muito sobre esso nos Estados Unidos, do [...] sobre origens e origem dos nomes porque a maioria são um mechlado, né [...] som mechlados assi.

(nacionalidade da mãe e pai) Mas [...] materna e paterna que quer dizer esso? Mesma coisa [...] mesma coisa. Nasceram nos Estados Unidos mesmos com os seus pais e seus pais, e antes de esso não sei, mas meu pai nasceu na Estado de Ayo; minha mãe em Forwad Texas duas horas de onde eu cresci, tá?

(Já aprendeu outra língua?) Já. Jo/Eu viajei por só seis semanas na Alemanha e depois dezesseis semanas eu falei mais ou menos um pouco de Alemão para conversar, algo assi, mas agora já esqueci; pelo menos fica na, nas [...] como se diz, atrás de minha mente. Jo/Eu morei dois, três meses em Venezuela e aprendei mais ou menos como falar Espanhol e eu estudei dois anos na Escola também, por isso eu falo mais ou menos Espanhol e eu cheguei aqui no Brasil com uma conhecimento da Língua Espanhola.

(Vida acadêmica) Eu cresci em Denessec - Texas - um cidade pequena de vinte e três mil persoas e eu fui a uma "Elementary School", Escola Elementário dizem lá, se chama mesma "Elementary Scholl" com não sê deve ser trezentos outros estudantes. Mudei para Middli/Merow School com vamos dizer mil estudantes e depois High School com mil e poucos estudantes e um [...] uma [...] um classe e um grupo de colegas de doiscentos/duzentos e vinte algo assi. Eu me graduei com este grupo de doiscentos/duzentos e pouco e em Denessec Texas mesmo, Denessec High School e depois eu fui para a Universidade de Texas, que fica Austin, Texas, a capital de Texas, com um milhão, populación de um milhão de estudantes e tem esta [...] esta Universidade tem cinqüenta mil estudantes, é muito. E o mais grande nos Estados Unidos, eu acho. 
(Gostou de todo esse curso?) Gostei muito. Parabéns tudo.

Quando e porque veio para o Brasil? Algum/Algumas razões: primeiro eu queria [...] já formei na Universidade de Texas; acabei com minha [...] meu curso lá; eu queria fazer uma coisa antes de começar com a Pós-Graduação. Eu vou estudar Medicina quando eu volto, se Deus, como se diz, se Deus quiser, não? Mas, primeiro razon eu queria uma descansa não, mas uma coisa deferente, um ano de enriquecimen algo assim, não? Outra razon para aprender a Língua, para meu [...] porque eu falo meio Espanhol; eu queria aumentar um pouco mia conocimiento das Línguas românticas, ou Romanças, não sê a palavra; por isso que eu estou aqui; além de isso eu queria estudar a Saúde Pública do Brasil; a Saúde Pública [...] eu vou também conseguir um Maestro na Saúde Pública e ser um especialista na Saúde Pública, Saúde Internacional especialmente e como todo mundo sabe, Brasil tem su [...] seus problemas neste, [...] este campo, por isso eu estou [...] eu pretendo voltar depois de estudar um pouco mais e talvez ajudar [...] ajudar um pouco, não? Jo estudei Economia enpolque na Universiade Latio-América por isso eu estudei muito os países hispânicas, mas [...] 0 Brasil foi um pouco ao lado porque uma exception, é deferente, não, por isso eu estou aqui também para completar minha educación sobre este continente, sabe? E a última razão foi porque eu recebi uma bolsa que foi especificamente para um país que tem uma língua que é pouco conhecido, por isso eu estou aqui. Essas quatro cinco razões, sabe?

Há quanto tempo no Brasil? Eu cheguei faz [...] hoje, que é hoje exatame [...] quase exatamente três meses. Sim, faz três meses, na [...] isso assi, exato.

(Sua profissão) Eu estou um estudante mais que tudo; como eu disse, eu estou estudando [...] vou estudar Medicina e vou ser médico e também uma especialista em/na Saúde Pública que quiere dizer que eu quiero fabiar com policia da Saúde Internacional, coisas assi.

(Outra atividade?) Coisas afora de estudar este campo, este sujecto, eu gosto da literatura, filosofia, questões filosóficas, especialmente sobre o campo de medicina; este, de verdade, é uma outra atividade que eu faz quando eu não tenho que estudar, sabe? Eu gosto da Antropologia médica também. São coisas acadêmicas, mas para mim são outras atividades. Além das coisas acadêmicas, eu gosto de [...] dos desportes, especialmente correr e tênis; também esquiar na água e também neve que temos lá nos Estados Unidos, neve; há possibilidade para fazer este em Colorado, outros estados, mas este mas o menos; atividades físicos e atividades mentais.

(dificuldades de adaptação) Does/Duas coisas: primeiro a língua; este [...] esse é lógico, não? Ah! mas eu não [...] eu estou falando agora mas eu estou falando com uma [...] como uma outra persoa/pessoa que 
é um rhyme polps, eu estou falando como uma rhyme polps de doze anos es mia/minha capacidade lingüística é assi e eu estou pensando coisas, mas eu tenho um camino muit [...] pouco largo para seguir estes pensamientos se você entende esse. Por isso, conversação e relações entre as persoas/pessoas que são muito importantes para todos especialmente para mim. Eu gosto muito para conversar, falar, aprender de outras persoas e com uma língua limitada é um problema. A segunda pers [...] coisa sobre o Brasil é uma coisa especificamente de São Paulo que é a estilo de vida urbana; este inclui poluição, este inclui transportação, este inclui falta de naturaleza e algumas vezes falta de alsêdino mesmo, não? É difícil de ser muito saudável quando você [...] estou respirando fumo muito tempo; você tem que passar uma hora para chegar dois quilômetros por ação do trânsito e você não pode passear uma parque, porque só parque que fica na Birapuera é uma hora e meia, duas horas da minha casa e não vale a pena e eu só tenho uma sala de exercícios para tentar mater/manter minha saúde e esso. Esse eu não estou acostumado de esse; não sei como as persoas aqui sobrevivem assi, mas é uma dificuldade mesmo.

(Pretende ficar?) Eu vou [...] minha programa dura até o dezembro, e depois talvez eu vou voltar, mas provavelmente eu vou ir para Santiago ou Buenos Aires para estudar mais Espanhol para equilibrar um pouco porque já esqueci um pouco de minha Espanhol neste mudança para Português, mas eu vou voltar; estou [...] não estou aqui para aprender a Língua e sair depois.

(o que estimula sua permanência?) Bom. Vão primeiro [...] primeiro as necessidades do país; primeir [...] tem coisas [...] tem tarefas aqui que precisam ser feitos e eu quero estudar para chegar a um nível de entendimento que eu preciso para ajudar. Segundo é uma cultura muito engraçado e também é tanto [...] tão engraçado como é bom de ajudar, não? para ser aqui.

(Por que é engraçado?) Porque é engraçado. O povo brasileiro são muito abertos e divertidos. Mui , mui [...] Eles ajuda quando uma persoa/pessoa perdido como eu a maioria dos tempos precisa [...] precisa ajuda e é uma país tão diverso quanto interessante e fica culturalmente.

(O que há de mais interessante no Brasil?) Mais interessante. OK Eu [...] sobre [...] sobre as coisas interessantes no Brasil. Vou falar mais sobre o povo brasileiro. Eu acho que primeiro: são um povo muito dinâmico; dinâmico quer dizer que são muito diverso e também integrado por ação de espacio e também coisas práticas que [...] que se juntam, sabe. Mas este tipo de dinamismo, quando eles [...] eles têm que trabalhar juntos, eles [...] classe sociais raciais/reciais etc [...] etc [...] tá, tá, tá, sempre estão [...] são interacting, não sê/sei a palavra, mas [...] 
mexendo mesmo. É esse tipos de interações entre pobres, ricos, negros, brancos, etc, etc. dá contraste des que não temos nos Estados Unidos. Segunda coisa sobre as pessoas aqui são as conversações; o dinâmico das conversações mesmo são diferentes: são mais vivos, são mais animados e esse quer dizer que todo mundo está falando mesmo tempo, mas tem ordem também; é muito difícil entender e seguir que está passando, mas é muito engraçado porque tem muito energia e esse tipo de não se/você ficar numa atitude onde todo mundo ficar uma mesa falando sobre três coisas ao mesmo tempo, mas todo mundo falando em sua vez, é muito interessante.

A primeira coisa que é interessante, mas não sei se é bom é a relação entre os sexos aqui no Brasil. É interessante para ver porque e/eu acho que existe mais machismo e mais sexismo aqui no Brasil e os papéis dos sexos são um pouco mais fixos e pelo menos, em minha concepção di fimamismo e igualidade entre os sexos é um pouco mais atrasado que eu acho ótimo, o melhor possível, sabe. Isso é interessante - essas três coisas sobre o povo brasileiro - me [...] me, como se diz, impressionou, sabe.

(O que perturba você aqui?) O.K. Um coisa que me incomoda aqui é a concepção do tempo e não é como tem uma concepção fixa; é uma concepção que muda depende na situação, por exemplo, as aulas podem començar vinte minuto atrasado, mas se eu vou encontrar com um professor, eu preciso chegar na hora, mas talvez ele não vai chegar na hora e não tem uma lista de regras para saber como, quando, para, que exemplos, que tempos você deve chegar na hora. Outro exemplo: eu cheguei dois, três minutos atrasado para uma cinema, um filme e não me deixou entrar, mas eu posso esperar uma hora numa café para encontrar com um amigo e este tipo de [...] de que eu tenho que chutar para saber quando chegar um lugar, para situações diferentes - é um pouco difícil e não - e este require muito - require muita paciência e flexibilidade que eu acho que brasileiros têm, mas como americano porque temos uma não sê concepção de tempo mais fixo, mais rígido, regular; e, talvez, eu prefero, prefiro a coisa que eu posso predicar, como se disse, prevenir, isso; isso! Uma coisa que eu não siento muita vantagem aqui no Brasil é como estou falando agora: tentar expressar mios, mias opiniões; como eu falei antes, é um pouco difícil para sentir como estou me presentando, como jo estou, sabe; não é que eu não [...] que eu mudo aqui; mas é a Língua não dá para expressar claramente como eu estou pensando e as coisas que são importantes para mim e este é um obstáculo para conhecer outra persoas; esse é uma grande desvantagem - comunicação de ser aqui, de vivir aqui no Brasil. E este desvantagem é quase [...] é, sem dúvida, para mim o mais grave, o mais importante, o mais difícil - es/é comunicar - es/é uma coisa fundamental 
para nós, nossos humanos, seres humanos e quando este tem uma obstáculo de língua é verdademente um pouco difícil.

Vantagens de ser em Brasil - de estar em Brasil, pode ser: são o povo porque são muito interessantes, abertos, engraçados e muito fácil para conhecer e formar amistagem. Outros vantagens são os [...] aqui no São Paulo, no São Paulo especialmente recursos culturais - tem coisas de todo mundo aqui e eu tenho acesso a comida de todo mundo: eu tenho do-nuts como lá, eu tenho também sushi que não tenho lá no Texas; eu tenho [...] já assisti uma teatro de um grupo de percussion da Índia; não tem [...] não temos na Austin, que é a centro cultural de Texas. Outro desventagem é a dificuldade de transportar-me em São Paulo e a poluição e as coisas que são verdade para toda centros urbanos do mundo. Outra vantagem é a flexibilidade porque tem menos regras sobre coisas como tempo, como que é ligal, que é não ligal, as regras culturais e regras ligais, também, são pouco mais flexíveis; se eu tenho acesso, eu posso entrar pronto-socorro aqui e fazer um estágio; eu posso ter acesso as cadáveres, mio exemplo, como médico, para cortar, para dissecar; e nos Estados Unidos porque temos muitos advogados que têm que ser, quem/têm que ser fazendo algo; temos muitos regras que [...] e enquanto existe muito burocracia aqui, talvez algumas vezes seja mais fácil de fazer algumas coisas, depende, depende na nivel de burocracia, mas burocracia aqui também é um desvantagem; existe - é uma coisa que demora muito e nós não somos acostumados a esso nos Estados Unidos e, por isso, este demora, estes [...] es para esperar para coisas que parece sempre ser pouco complicado [...] isso!

(Do que você sente falta?) Eu sinto falta de algumas forças/coisas: primeiro a minha família; este é típico, não? Eu gosto muito de mios pais, mia irmã, irmão; somos cinco e eu sinto falta de eles; também amigos. Em quatro anos, eu tinho [...] , eu estava estudando, eu tinha amigos da Faculdade que já são [...] alguns estão estudando, alguns como eu são no mundo fazendo alguma coisa e eu sinto falta de estas persoas importantes na minha vida. Sinto falta da [...] para ser fluente quanto estou falando e expressando mios pensamentos; sinto falta da [...] do meu carro, transportación, a palavra, es auto-pista em espanhol, que é aqui? highway, né? mas os caminos, os "roads" mesmo são [...] são um pouco melhor por ação de menos trânsito e também são mais, não sei, plano lá e por isso eu posso chegar em qualquer lugar e pegar qualquer coisa, comprar qualquer comida, fazer qualquer [...] não sê encontrar qualquer persoa dentro de meia hora o máximo; aqui não, aqui não. Eu acho que ess [...] e também eu sento falta de água clara, rios limpos, ar limpo também, um camino para correr, para fazer exercícios, coisas assi. 
Uma diferência muito grande aqui é o comida, especificamente, o conceito de "por kilo" é muito bom porque é muito saudável, tem todos os grupos de comida, de legumes, etc. Nos Estados Unidos é evidentemente mais difícil de comer comida saudávels - saudáveis - é difícil cheg [...] é difícil achar uma coisa que dá bom para o corpo; aqui todo "por kilo" tem salada, tem coisas assi - é muito mais fácil. Esta é um diferência que favorece o Brasil, sabe.

Semelhança entre [...] eu vou falar um pouco sobre os sociedades, entre os dois países: bom, tem uma diferência na Língua; tem uma diferência no estilo de vida e out [...] coisas culturais também, mas é engraçado, é interessante como os estudantes aos [...] pelo menos os na USP que eu tenho conhecido, eles têm uma desejo de aprender e entender e lutar para coisas que eles acham importantes e este tipo de energia que talvez é uma diferência também porque talvez existe aqui este dinamismo - dinamismo é talvez um pouco maior aqui que nos Estados Unidos; os jovens, eles vêem os problemas, os meninos na rua, eles sabem que têm problemas nos políticos; su país mesmo es uma época muito importante e muito [...] é um sentido novo economicamente; eles sabem que este é muito importante; eles sentem uma responsabilidade de ser envolvidos em este processo de melhorar o Brasil. Este; esse atitude não existe tanto nos Estados Unidos.

(Onde passa a maior parte do tempo?) Eu passo a maioria de meu tempo aqui em a USP e passando entro de a [...] da USP e a USP quer dizer a Cidade Universitária e também Saúde Pública e Medicina aonde estou fazendo coisas também e passa [...] eu acho que três horas por dia é passado transportando entre os lugares e o resto é só estudando, lendo, ou tendo aula. E quando não estou na USP, ni passando para a USP, estou em casa usualmente [...] e si estou em casa, estou lendo ou fazendo exercícios nossa sala de ginástica ou dormiendo, sabe. E quando não estou em casa, a USP ou passando entre casa e a USP eu estou num café ou restaurante com amigos brasileiros ou americanos falando.

Eu acho que o brasileiro andão mais, valoriza mais as relações entre as persoas e, amigos, família especialmente, mais que tudo talvez a família, eu acho que toda a vida, talvez, relata o tem que ser com um aspecto da família e as [...] o únito familiar eu acho fundamental para a cultura brasileira.

Vou falar brevemente sobre dois hábitos: o primeiro engraçado, este é o hábito de dar beijos no rosto e é muito engraçado; não fazemos lá e eu acho que a cultura americana nunca vai fazer, mas é uma coisa que é bem valorizado aqui e é bem engraçado. Talvez deve ser implementado em todo o mundo, não? Uma outro hábito perigloso que eu veo nas ruas são as [...] a métoda de dirigir aqui, especialmente os 
motorciclistas é uma loucura; muito perigloso e eu imagino que tem muitos acidentes que podem ser evitados [...] fatais e também evitados com, com um [...] um [...] algum tipo de, algumas regras de tráfico um pouco mais rígidos e talvez um pouco so [...] algumas policias bem reforçado a essas regras; é verdademente uma, vou dizer, entropria nas ruas, é um [...] falta de ordem e este [...] funciona um nivel e também outro nivel é muito perigloso.

O.K. Um governante que eu admiro aqui é axualmente Fernando Henrique Cardoso porque eu estava lendo hoje mesmo sobre seu policia equenômica e que, de verdade, ele não é perfeito, mas sua policia equenômica tinha ajudado muito para a estabilização da currencia brasileira, da fiá mesmo e agora tem [...] temos algumas mae [...] agora temo [...] Brasil e nós também temos alguma problema com a economia mundial, mas ele é a autoridade de este país e neste question e est [...] e neste problema sério sobre a economia e a corrente, a moeda, moeda de [...] do Brasil; e eu acho, eu admiro sua conhecimento econômico mesmo. Nos Estados Unidos é um dific [...] é um pouco difícil porque estava passando um econge nossas [...] nossa figura, nossa chefe, nossa presidente mesmo (es)tá tendo algumas problemas e eu posso citar algumas coisas que eu admiro sobre ele, sua estilo de falar e de ganhar os amor da [...] do povo, mas quando este está baseado em mentiras, é um pouco difícil de dizer que eu admiro a ele, sabe. Por isso, vou deixar este [...] este parte da pergunta ao lado.

O grande desejo aqui em Brasil que eu acho que existe em tudos lugares é o desejo de melhorar e ser um país, um dos líderes dos país que [...] no sê a palavra [...] que Brasil para na cabeça; este é o desejo mesmo para entrar na [...] no primeiro mundo, para desenvolver.

Necessidades são óbvios: falta dinheiro, tem favelos, tem meninos da rua, falta saúde, tem uma expectativa da vida muito curto, não? tem problemas médicos muito sérios, problemas com literacia, alfabetismo muito sérios, educación, temo uma falta de confiança nos políticos é [...] que é muito sério e é um obstáculo mesmo de formar que [...] a coisa que Brasil precisa mais e é uma identidade nacional. Essa identidade pode ser baseado na diversidade, mas este é o [...] eu acho o grande desafio agora em [...] no Brasil e eu estou falando completamente de [...] do ponto de visto americano em todos esses pressupostos, viu? Eu gostaria dizer a [...] o, esta é uma de/seleción, mas mais uma "complement" aos brasileiros e uma coisa que eles devem saber sobre se mesmo e o brasileiro tem um capacidade que não temos muito nos Estados Unidos; é uma capacidade de identificar as falhas que eles têm, as coisas que eles precisam melhorar. Nos Estados Unidos somos tranqüilos: achamos que estamos muito legal e corretos e o problema é que o brasileiros, algumas vezes, eles assumem esse também; eles 
acham que somos civilizados, quando temos um problema grave de [...] que não podemo [...] Somos um poucos cegos a nossos próprios problemas e coisas [...] porque somos tan cômodos também; não somos como eu disse antes dinâmico como os brasileiros e este força, este vantagem que Brasil tem pode ser usado para melhorar e não se estático como eu acho, algumas vezes, somos lá nos Estados Unidos.

\section{A sugestão a o [...]}

$[\ldots]$ ir [...] estudantes estrangeiro inglês que vêm aqui para 0 , ao Brasil, é o seguinte:

Quando coisas são difíces e vão ser difíces, quando você não so [...] pode comunicar, quando você fica um pouco doente, porque você comeu alguma coisa que passou mal, só esperar um pouco porque vai, vai melhorar; este é uma, é um fenômeno humano, não? que tão [...] que temos um mau humor e ou quando estamos pegando um época difícil, é [...] parece [...] nos parece como [...] nos parecemos como vai durar sempre, mas eu, eu aprendi aqui que quando eu sento triste, mal, eu sento saudade muito forte para meu país, eu espero um dia, vinte e quatro horas e coisas melhorar, cois [...] de verdade e este tipo de paciência [...] você tem que dar tempo para ajuscar [...] ajuscar a palavra? [...] ajustar à cultura e coisas não periora [...] como se diz? não vai piorar, vai melhorar; este, este eu falo com certeza que coisas são mais e mais fáceis; não são mais e mais difíceis aqui e est [...] a época quand [...] começar não é difí [...] ; é difícil este tip [...] este periodo de ajustar; é verdademente pouco traumático, mas passa com certeza e estou saindo agora e eu sei que a meu [...] melhora, sabe?

Eu acho que falta primeira sobre a Inglês aqui no Brasil pelo menos eu não tenho falado muito com, com os estudantes que falam Inglês, mas eu acho que a Inglês aqui deve focar mais na conversacion e a pronunciacion e menos nas regras porque talvez com sua exposto a television e Inglês falado, os estudantes, eles conseguem entender os ordens das palavras; eles conseguem entender a gramática, mas eles não [...] eles estão escutando e aprendendo; eles não estão falando e aprendendo; eles não estão falando e aprendendo [...] por isso [...] não estão praticando e por isso eles podem, eu acho que eles podem conseguir escrever ou pelo menos construir uma com frase, mas eles não podem enunciar, falar esse frase.

O.K. Eu tenho alg [...] uma idéia talvez que pode ajudar para formar uma, uma tipa de esport [...] , uma aula de Português bem legal; eu estou fazendo agora uma aula assi que é legal, mas de essa aula eu [...] eu [...] como se diz [...] eu saquei algumas coisas que pode ajudar, não?

Primeiro, eu acho que conversações na aula são bons; conversações sobre coisas brasileiros que são importantes para os 
americanos e brasileiros também; mas o problema e se [...] eu acho que este pode ser o método de ensinar Português e as regras podem seguir em sua vez quando, quando são, quando surgem no [...] na conversaçasion. Este pode ser 0 [...] aos estrutura, pode ser um estrutura tópica mesmo, de [...] topical, beseada em essas conversações e a fundo de essa presenta as regras e as coisas gramáticas, mas o problema com esse é que usualmente representantes da cultura brasileira é a professora, o professor e este dá um pouco, é um pouco difícil porque se quando os estudantes estão falando sobre coisas que são importantes e o professora não concorda, ela pode com um português melhor, com um conhecimento melhor, ela pode negar 0 estudante sem realizar que ele está tentando primeiro aprender Português e também expressar seus [...] seus, seu ponto de vista numa língua que é muito difícil para ele; este décico livre do poder pode ser um problema e este precisa ser evitado; os professores precisam saber que os estudantes têm sus problemas para expressar e têm, sus limitações de [...] de [...] culturais e ele, e este uma obstáculo, um desvantagem de este tipo de curso [...] e também não chegam a falar exatamente a coisa que eles querem falar e eles podem sentir um pouco, talvez um pouco inteligente quando a professora usa sua ventagem de língua para negar as coisas culturais que achem verdademente as opiniões dos estudantes ingles ou americanos que são fundados na outra cultura deferente, sabe.

Eu acho que falamos sobre que está faltando no ensino de Português; pode ser vocabulário porque depois de aprender as regras, você pode notar as regras nas conversações que você escuta e fica mais e mais claro depois de uma só presentacion; o vocabulário porque é tan amplio, um pouco mais difícil; eu acho que cada dia, cada aula deve ser, deve ter dez palavras de vocabulário para aumentar ao vocabulário dos estudante e deve usar, deve ser um aprendimento visual porque são, a maioria vão ser verbos ou substantivos; pode usar um fotogra [...] foto, foto, um foto ou uma pintura, uma description visual de uma acción, uma coisa que fica mais clero, não? [...] (repete a sugestão:) ilustrar que é mais fácil aprender assim.

Falando sobre metodologia, eu acho que temos muito convers [...], temos conversacion, usamos a aula para conversar, falar sobre canciões, falar sobre uma coisa cultural; talvez fazemos exercícios na apostila, mas eu acho uma coisa bem legal para ajudar com escrever que talvez falta um pouco, é dar a liberdade para estudante escrever sobre uma coisa que ele quer escrever e não estou falando sobre um diário porque esse é demais, aberto demais e também um pouco [...] algumas, algumas persoas não gostam de escrever cada dia sobre que eles fez cada dia; talvez uma question aberto sobre a cultura, uma coisa 
sobre a [...] intercâmbio mesmo, este cult [...] coisas, compliques culturais que pode surgir, coisas assi. Narrativos para tarefa que pode ajudar com a língua, com escrito da estudante, também para processo de ajustamento, mesmo tempo.

Eu acho que é fundamental que os estudantes que têm uma fundacion, uma [...] em uma outra língua, usa esta fundación para construir o Português; eu falei Espanhol e eu estou fazendo uma aula com uma professora que fala Espanhol e ajuda as coisas que sabemos para ajudar com [...] para aprender a Português e não deve botar para fora as coisas que os estudantes já sabem e se é possível vincular também as [...] a estrutura Inglês com a estrutura Português, com a fundación de algumas regras para relatar e comparar também as coisas que ficam completamente diferente e também semejantes.

Bom, sobre [...] para conseguir comunicar, se comunicar Português, precisa falar devagar e esse é um problema meu; eu sempro tento falar o velocidade que eu penso e não posso falar em Português este de velocidade, é impossível; e talvez vocês notaram que eu falo talvez demais, demais rápido considerando minha habilidade de pronúncia, sabe. Mas, eu esperei, eu queria chegar e aprender a Língua Português uma mês, eu queria estudar todo tempo vocabulário, estructurais verbais, coisas estructurais verbais, coisas assi para falar perfeitamente dentro de um [...] uma semana; é impossível! A Língua são para estudantes como eu, estudantes de [...] eu estou estudantes das Humanidades e uma língua , uma [...] um grupo de regras e um pouco seca, não?; é difícil sentar e estudar um dicionário; é demais, por isso, a língua tem que ser intrigado com coisas que são interessantes, dependem [...] que dependem nas necessidades e interesses de cada estudante. Cientistas pode ser assignado, pode ser dado artigos científicos, coisas assi. Tem que vincular as coisas que estudantes sabem com a coisa que eles estão aprendendo, que é a língua Português.

A maior dificuldade para um estrangeiro é gênero, deve ser. não temos, não temos [...] nossos sujeitos, nossos substantivos não têm sexo; também nós [...] bom não temos que é futuro de subjuntivo, essas coisas quando cad [...] , como o tempo, cada tempo que se você está fazendo alguma coisa, mas não sabe; existem dúvida, não existem dúvida, pode ser; é [...] são coisas muitos "intengible", não sê a palavra, mas abstractos para a mente americano ou para o falante de Inglês, porque não temos essa tipo de coisa.

Subjuntivo, pode ser subjuntivo e gênero como as maiores dificuldades para o estrangeiro e também a quantidade de [...] das palavras novas, sabe.

(Gostaria de fazer alguma pergunta?) Talvez uma pergunta pode 
ser, qual, qual hora da dia é melhor para aprender uma língua, a manhã, a tarde, durante o armarço, durante a noite, com que freqüência, quantos [...] quanto tempo dura a aula, coisas assi; precisa um intervalo?

Uma pergunta que seria interessante é perguntar que é a coisa mais, mais surpreendida sobre o Brasil, mas também que é a coisa que, que ainda fica misterioso sobre o país, que, não que pode conseguir entender embora você tenta entender, sabe.

Uma outra pergunta possível é que são [...] que eram os preconcepções sobre o Brasil e também a Língua Portuguesa porque alguma [...] alguma persoas acham que [...] fica igual que Espanhol; a outras persoas acham que [...] são um pouco ignorantes e não sabem que Brasil falam Português; acham que falam Espanhol ou outra língua assi. Você pode incluir a palavra recurso na [...] devo gravar esse? [...] você deve incluir a palavra recurso porque este é um grande diferência recurso sobre informação - como computadores bibliotecas [...] é um mundo deferente aqui que lá. E este fato de facilidade deve ser, não sei, expressado.

Por que a propósito [...] , o produto final de este pesquisa vai ser uma coisa para o país e não só para São Paulo; talvez deve, não sê a palavra extrapolar um pouco na entrevista sobre as diferências entre São Paulo; que os estudantes acham mais fácil aqui em São Paulo para aprender a língua e para ora - a cultura entre [...] e outro lugares; se eles conhecem outros lugares ou se não ou pode ser as concepções da educacion do Brasil do difer [...] , partes diferentes do Brasil. O problema é que não acho que os estudante americano vai, vai saber muito sobre esso.

O.K. Uma coisa que eu falei sobre uma semelhança [...] semelhante entre [...] uma coisa que fica mais ou menos igual eu disse faz tempo entre os estudantes brasileiros e americanos e sua nivel de, sua curiosidade; mas uma diferência é que os estudantes americanos [...] os estudantes brasileiros são mais [...] são muitos ligados e dedicados a questões sociais, mas os estudantes americanos são muitos ligados a [...] ao educacion mesmo. E este tem excepções; eu estou pensando uma discussión que eu tinha uma aula aqui que [...] que foi muito legal, mas o nível de respeito e de atencion na [...] nos cursos aqui e a concepcion da educacion que é como uma coisa que é muito importante foi pelo menos superficialmente eu não notou aqui como eu notei or notava lá nos Estados Unidos. Este dá para entender? mais ou menos? 


\section{2 - CAROLINE - Ohio (EE.UU)}

CAROLINE from Cincinate, Ohio, mas agora eu estou estudando em Madison, Kansas.

Ambos são americanos, e acho que meu pai tem um pouco de sangue, acho que irlandesa, mas só isso.

(Sua mãe) Também, só americana.

(Outra língua) Espanhol e estudei Francês uns dois anos, mas mesmo assim não falo muito bom. E estudei Sueco e também Japonês, mas para falar mesmo, é só Inglês, Português, Espanhol.

(Vida acadêmica) - (quais as áreas?) Mais sociologia e idioma. Também [...] (algum instrumento) não. Só coisas assi eu acho: História, um pouco; Sociologia, muito a literatura, também, demais; literatura: brasileira, portuguesa, espanhola, latino-americana, demais! Demais.

$\mathrm{Eu}$, gente, quando eu tinha uns quinze anos, conheci um brasileiro, que chegou a ser muito amigo meu, então ele me ensinou, que me [...] primeiras palavras de Português, a samba, coisas assi. Adorei demais, então queria estudar Português, mas não é muito bom lá, então precisava esperar até faculdade. Comensei a estudar e amei a cultura, amo a cultura, as pessoas assi; acho que o idioma é muito bonito. Então, por esso vim aqui e quando eu comencei a estudar com isso, faz dois anos, assi [...] eu tinha uns dezoito anos; agora tenho vinte!

(Pretende ficar no Brasil?) Agora vou ficar uns seis meses, não sei. Probles [...] não sei se posso ficar mais por causa de problema de dinheiro, e coisas assi com a Faculdade também; porque a Faculdade tem que aceitar tudo, todo curso assi; é complicado mesmo; tem muito burocracia; esse é problema, né?

(Sua profissão?) Sou estudante e também ensino Inglês. (Inglês?) $\mathrm{Si}$

Outra atividade?) Para trabalhar? Antes eu trabalhava numa loja Kenmart assi para ser a woman, as coisas assi, com supermercado, assi, bem chato, mesmo. Não foi uma coisa grande, não.

(Adaptação) O Idioma? Ah! Difícil? Uhm!! Vamos ver. Em São Paulo? [...] eu acho que as pessoas são muito frias; são [...] é difícil conhecer pessoas; é difícil fazer amizade; e São Paulo é tão grande que é difícil chegar a um lugar; sempre fico perdido; porque, Cincinati não é tão grande, não; tem uns dois milhões que não é pequeno, mas também não é grande como São Paulo; então, foi um choque para mim, São Paulo. Ah! Que mais ?! Acho que o brasileiro é bem deferente que o americano, assi [...] coisas assi [...] coisas culturais assi e, também, por exemplo, no Brasil uma coisa pode ser a sacanagem, mas para mim não é; e também a/o contrário , uma coisa/para mim é sacanagem, mas não 
é, para eles. Então a gente fica chateada sem saber por/que. Eu machuquei alguém sem saber porquê e alguém faz uma coisa terrível comigo que não consigo entender por/que eles são capazes de fazer isso. Coisas assi.

(Pretende ficar aqui?) Permanente, assi? Acho que não. (Quanto tempo pretende ficar?) Seis meses. (O que te estimula aqui?) As pessoas. Tinha que ter umas conexões mais fortes. Agora tenho uma conexão superlegal com minha família hospedeira, mas é a única coisa que eu tenho aqui. Não tenho outra coisa, não. Não tenho amigos, né. $E$ lá tenho muitos amigos; já estava acostumada ter amigos, assi. Aqui não tenho; não consigo ter amizade aqui em São Paulo; só com americano; aqui com americano, estrangeiro, Inglês, gente demais. Mas eu quero amizade brasileira; conhecer brasileiros, e não dá; sempre não dá. $E$ sabe o problema? É que [...] o bra [...] parece, heim? Porque não quero ofender ninguém. Mas parece que os brasileiros têm muito interesse em ser meu amigo quando vão aproveitar alguma coisa, quando vão ganhar. Por exemplo, como eu vou ensenhar Inglês para eles e passar o tempo todo falando Inglês, eles saem assi: Esta é minha amiga Carol; ela não fala Português, eu falo Inglês; sou o máximo [...] legal com ela, assi; é mais show, mas uma coisa verdadeira não, não tá. Inclusive que nos Estados Unidos eu tinha um amigo brasileiro, paulista, paulistano. E ele morou lá uns três meses; a gente foi muito amigo; ele não conhecia ninguém; sempre saía com ele: levava ele para lugar, para sair, conhecer pessoas e quando eu cheguei aqui em São Paulo, você acredita que ele saiu comigo só uma vez; nem liga para mim e quando saiu só para falar Inglês; para para me levar a lugar e ele só falava em Inglês, [...] isso, para se mostrar e [...] eu estava passei um tempo muito ruim; estava muito doente mesmo; ele nem [...] não ligou nada, nada, nem taí, nem taí, nem liga nada e ele mora aqui num/uns dez minutinhos da minha casa; ele tem carro, dez minutinhos, fala que ta longe, num sei quê que tava tão ocupado, que não tem tempo. (Você liga pra ele?) Já não; já era. Porque [...] é porque [...], que é falsidade. Você não acha que é falsidade? Fiquei chateada demais.

Interessante [...] ( $\mathrm{O}$ que você acha de mais interessante aqui no Brasil?) Tem muito coisa. Eu gosto muito das religiões populares como Candomblé, coisas assi, que aqui o brasileiro é muito espiritualista, assi. Também gosto muito da música que é [...] muito legal e eu acho muito interessante a sexualidade no Brasil, porque tem muito ênfase a sexualidade, que a mulher sempre vai tan bonita, se assi arrumado com, a roupa chique, bem pintado e, muitas vezes, em saia bem curtinho, coisas assi. Eu acho interessante ver a relação entre homem e mulher, o machismo. Sei lá, é bem diferente, assi. A coisa que homem fala na rua que lá a gen [...] homem não fala essas coisas assi: gostosa, lindeza, ih 
[...] tá [...] ce sabe como são os homens, né? Mas lá, nossa, a gente não fala es muito mal visto, Todo/Só latino chega e falam isso. Então, a primeira vez que eu saí na rua fiquei bem impressionada. Que falou?

(O que mais perturba, incomoda) Falsidade. A falsidade mesmo e também tem muito brasileiro que non [...] que parece impaciente com o Português da gente, assi [...] non vai, nunca vai falar alguma coisa fea, mas fica um pouco frustrado: O que? Você não entendeu? Ah! Deixa eu te explicar, esquece, deixa lá. Oh! Muitas vezes só querem falar Inglês. Você chega, pergunta alguma coisa [...] responde em Inglês e eu pergunto alguma coisa, por exemplo na rua, por favor, cadê esta rua, me poder explicar chegar lá; não sei quê [...] Ah! You are American. You speak English! Assi e para a gente, quando você contesta, responde ou demanda da pessoa é comen su - ta [...] encho [...] que você não sabe falar direitinho; que eu tenho que sabe dizer porque você nem/é que não sabe. Acho que aqui não é isso mesmo, mas para a gente foi um grande sacanagem; agora estou acostumada, mas [...].

Vantagem: é um país super lindo, né? Tropical, assi, coisas bem bonitas aqui que eu gosto muito. Também tem outra comida, frutas, demais, demais [...] isso, legal, né? Também para conhecer outra cultura, outra maneira de ser - (the landscape) bonito mesmo (and the weather) ah! Eu gosto muito, gosto muito aqui o tempo.

(As desvantagens - o que não é legal, por exemplo) que não é legal, ai gente eu acho que [...] , aqui em São Paulo, não sei de outras parte, mas é difícil fazer amizade, mesmo, assi um [...] São Paulo é uma cidade muito fria, sinto muito sozinha, sinto muito, muito solidão desde que eu cheguei aqui em São Paulo; todo mundo tem muito pressa; só corre para ii pua aiã; ninguém tem tempo para nada e também tem muito pobreza que é [...] é demais, que não tem esperança para melhorar e também que eu acho complicado mesmo é que tem pessoas muito ricas e pessoas muito pobres e assi que tem tanta deferença que [...] exagerado, eu acho, mesmo que a família minha hospedeira brasileira tem tantos problemas de dinheiro; todo dia um problema e ver o sofrimento é difícil, é duro para a gente; é frustrante também porque não tem esperança; também o governo não tem problem [...] não tem, também não tem programa social para ajudar o político não faz nada; só chega lá na televisão na hora certa para parecer o máximos, mas quando tem problem, quando precisar de algo, não tá lá; não tá nem aí.

(Saudade dos EE.UU - o que te faz lembrar - alguma coisa que faz lembrar) A música; escuto muito música americana, também tem muito MacDonalds e [...] que mais [...] (The behaviour?). Acho que não porque é muito deferente, deferente mesmo eu acho, mas São Paulo lembra, São Paulo lembra porque é mais parecido a cultura, eu acho, porque é metrópolo aqui em São Paulo. 
(maior parte do tempo?) Na casa, com minha família hospedeira.

(Mais valorizado pelo brasileiro?) Se divertir: sair, ir à praia, tomar cerveja, descans [...] Se divertir assi: sair com amigos, tomar cerveja, relaxar e não pensar nos problemas; eles não querem pensar no mal, coisas assi diria.

(Cite hábitos engraçados) Essa de beijar. Eu acho engraçado; você não conhece a persoa e querem te beijar; assim [...] acho deferente mesmo.

(E estranho?) Estranho [...] huumm estranho estranho acho que na [...] (e diferente?) Diferente tem demais. Esse de beijar de novo. É [...] também que, que eles quando falam com você, muitas vezes não falam a verdade, que eles sentem não é?, que em vez de falar assi a coisa certa, por exemplo, to com fome; fala um muito de coisa e faz um círculo... E, você tá com fome? Assi [...] Ah! Essa comida é boa? Você não gostaria provar, experimentar? Em vez de falar "tô com fome". Faz muito seco, assi. Entendeu?

(Algumas reclamações) Ah! É demais, demais, com isso. Esse de banco, é ridículo! Que o estrangeiro não pode abrir conta. Imagina! Eu cheguei aqui; trouxe um traveler-cheque por mês, porque eu estava esperando abrir uma conta e depois transferir o dinheiro e ninguém, inclusive o Cônsul, que é a organização da gente, não falou nada, que estrangeiro não pode abrir conta. Imagina! Chego aqui, eu tenho dinheiro? Imagine! Discrinin [...] minação? Que eu faço? Fui a muito banco, Ah! Mas você não pode! Por que? Me explica por que eu não posso. Ah! Porque é assi. Como que é assi? Isso é discriminação. Eles falam, sei lá, que tem estrangeiro que vem aqui, escreve um cheque que não tem fundo, mas, mesmo assi, não é justo porque lá nos Estados Unidos qualquer estrangeiro vai lá e abre uma conta, acabou o problema. Imagina, inclusive, ninguém queria trocar meus "travelercheques" que são Visa, não são American Express. Tanto problema e agora acho outra maneira mais [...] eu acho injusto. Imagina um estrangeiro que vai vi vir aqui um ano, dois anos, como que faz? $\mathrm{E}$ se tem problema de ladrão assi [...] como que eu ando assi com muito dinheiro em minha bolsa; eu vou com medo; eu acho injusto mesmo.

(E biblioteca?) Ah! É demais esta USP. Que injusticia! Porque aqui estrangeiro não pode tirar livro da biblioteca; pode entrar e usar, mas eu preciso levar um livro a minha casa, não sabe? Usar dicionário, coisa assi. Não consigo ler nessa biblioteca. E além disso nem está aberto fim de semana. Eu não tenho tempo durante a semana; tenho aula e também dou aula. Como é possível fico lá na biblioteca lendo? Todo brasileiro pode tirar livro; eu não. Dou aula. Então [...] não tenho tempo: eu chego aqui bem cedo, tenho minhas aulas depois tive que sair correndo para chegar a outro lado da cidade para dar aula de Inglês. E 
outro brasileiro? Por que brasileiro? Usa biblioteca e sabe que estrangeiro pagou para vir aqui. Paguei demais, exageradamente, e eu recibo nada. Só problema recebi com esse de biblioteca. Você não tem direito a nada. Eu acho discriminação. Como é possível? Você não pode tirar livro porque você não é estrangeiro. Fala que a gente não tem número de USP e por isso, mas não dão número de USP ao estrangeiro. Se isso realmente fosse o problema, daria o número da USP e cabou o problema, não é verdade? Então me explica por que não dão o número da USP? Imagine.

(E os amigos, querem falar Inglês ou Português?) Ai, menina, só Inglês. Só Inglês exagerado. Eu, eu vim aqui né? Para praticar meu Português; eu chego aqui tem pessoas que nem querem falar, que nem sabem falar Inglês e querem praticar, mas não sabem, não entendem quando eu falo e eles muito menos conseguem falar; então, porque eu tenho que me sacrificar para ensenhar Português; se querem tem um curso que Viagem não sei quê, não é, não é minha responsabilidade. E, puxa, inclusive, tem um amigo aqui, eu cheguei aqui, não é? e ele só queria falar Inglês, desde o primeiro momento, não é? e ele não entendia nada, não falava nada e eu falei: meu amigo acho um estúpido, não é? por favor, estou aqui para aprender Português, me ajude, assi, tenho pouco tempo. Não seria melhor falar Português? Ele falou que eu sou egoísta, porque eu não quero ensenhar Inglês para ele. Eu falei: não, eu acho injusto. Lá nos Estados Unidos, só falam Inglês com brasileiro, não fala Português, não porque tem que ajudar as pessoas. Eu estou no Brasil, não estou lá; não quero falar Inglês e ele que falou que eu sou egoísta. Eu acho egoísmo mesmo de uma pessoa; assi eu acho egoísmo de insistir fazer questão de falar Inglês comigo, inclusive uma vez alguém acho que lá na rua queria falar comigo, assi fazer uma entrevista lá na MASP. Eu não queria; eu estava com muita pressa Falei Ah! não fala Português e ela: Ah! Você fala Inglês? Começou a falar Inglês comigo. Falei. Muito menos queria falar Inglês com ela, né? Então falei não, não falo Inglês, também não. E ela: de onde você é? Falei: Suécia, que é mentira, né? Só para não falar Inglês com ela, e ela: mas/[...] se você é Sueca tem que falar Inglês, ficou insistindo para falar Inglês. Comecei a falar Sueco com ela: (começa a falar alguma coisa em Sueco com a entrevistadora) e comecei falar com ela e eu [...] ah! Que isso e foi embora, graças a Deus. Mas, coisas assi que eles não acreditam assi. Inclusive, agora não/nem vou falar que sou Americana, viu? Vou falar que sou Sueca. E [...] eu falo. Ah! Eu falo Sueco, desculpe não falo. O meu sotaque, o Sueco é parecido a Inglês, viu? e por isso tenho sotaque, mas nem quero falar que sou americana porque as pessoas abusam.

(Sobre o amigo em Ouro Preto) Mas, mas ele é americano, essa 
es [...] É. Pois eu ouvi falar de uma amiga, não é? que ele [...] ele foi um jantar, assi. Todo mundo estava jantando e ele de repente queria ir embora. E todo mundo falou, "mas como que você vai embora, esse é impossível, né? Você pediu comida já". E ele falou: "mas tenho que ir; vocês podem comer minha comida". E minhas amigas falaram: "não, a gente não quer comer a sua comida. Você tem que pagar. A gente não tem dinheiro". E ele: "tudo bem, eu pago", mas não queria. Mas ele saiu; ninguém sabia onde ele estava e ele tinha a chave do hotel, né? Então, ele chegou uma hora assi da noite. Todo mundo lá esperando ele. Nem podia subir a hotel, porque o hotel não tinha outra chave para deixar a gente subir. Então, a gente ficou lá esperando. Acredita?

(Um governante que admira) No Brasil, puxa! Acho que não. E [...] não é porque a político aqui culto, assi. Não é isso. Não conhece muito a política daqui, mas eu acho que Lula tem umas idéias boas, mas ele também exagera, eu acho. Então, realmente não conheço bem a política.

(E na América?) Sei não. Sei não.

(Fale sobre seus desejos e necessidades) No Brasil? É [...] eu preciso melhorar meu Português demais. É [...] mas gostaria falar ainda melhor, sabe? É difícil achar um bom curso. E, além disso, achar ninguém que quer falar Português com você. Isso é difícil para a gente. É [...] também, acho que eu preciso mais direito no Brasil, eu acho: as coisas do Banco, biblioteca. E muito difícil! Ah! Inclusive outra coisa que eu esqueci de falar, que é demais. Aqui a [...] o estudante da USP pode pegar pas do ônibus para [...] em vez de pagar um real para usar ônibus, é cinqüenta centavos, e [...] para o ano todo, o semestre, né? Olha aqui, o estrangeiro não pode! Eu tenho que pagar um real, mas o brasileiro paga cinqüenta centavos que é estudante. Você não acha injustícia? Eu acho demais, porque além disso que eu fui e comprei a semana/o semestre - paguei para usar USP. Brasileiro não pagou; paguei e que que eu tenho aqui? Que que eu tenho? Não tenho nada. Não tenho biblioteca, não tenho Banco. Não tenho nenhum [...] direitos. Eu acho injusto, coisa assi que eu acho necessidade de [...] de enquanto eu estou aqui que me trate como brasileiro, que eu tenho a direito, a acesso às coisas que brasileiro tem.

(Conselho a um amigo que esteja chegando) De [...] que tem que ser paciente, assi, no Brasil, que as coisas tomam mais tempo para acontecer; tem muito burocracia no Brasil; você chega lá uma coisa simples como, por [...] por exemplo, abrir uma conta no Banco. Coisas assi que são simples, que devem ser simples e não são e tem que ficar paciente e não ficar com raiva; ficar calma, tentar entender coisas assi, que é frustrante para a gente porque o $E$ [...] lá é outro sistema de vivir, outro sistema de política, coisas assi; é diferente mesmo para a gente; 
para não ficar frustrado e também, olha aqui, também eu diria para dizer que não é, que não fala Inglês, que vem de outro país, para não falar Inglês.

(fale sobre o Ensino de Inglês aqui no Brasil) Ah! É absurdo é terrível, TER-RÍ-VEL; eu acho uma vergonha, mesmo. Eu posso dissir si que professor muitas vezes não sabe; não fala Inglês. Eu fui a uma aula de Inglês na Yazi [...] Yasigi, é. Fui lá com meu amigo e essa mulher que é uma nível alta de Inglês com meu amigo, fui lá. A aula foi terrível; [...] isso "advanced" é/e ela falou terrível; a pronúncia dela não foi boa; ela usava palavra incorreta; não sabia [...] poucas coisas e gramática estava ensinando mal; como uma professora vai ensinar mal? Eu queria fa [...] acho que não falei nada, mas pensei: como é possível? E todo mundo ficava falando besteira na aula dela, porque ela que [...] lá ensinando besteira. E eu acho absurdo e, muitas vezes, esse/isso que eu notei do Brasil, né? Aqui ensina muito palavra, ensina muito! O Brasileiro conhece muito palavra e até expressões, mas não sabe conectar as palavras, fazer uma boa frase; não sabe a gramática; não sabe a deferença entre, sei lá, "eu fui" e "eu vou", coisas assi que faz err [...] erro qui simples, esse de "I am going" em vez de "I go", não sabe deferença;esse é coisa básica, puxa! E o "past perfect", "present perfect", "continuance", isso. Não sabe nada; e mesmo o professor não sabe ensinar. E [...] eu acho, tudo bem, saber palavras, que brasileiro sabe monte de palavras, mas não sabe fazer uma frase; então essas palavras não sirvem para nada, que não sabem gramática básica. (e os professores? Não estão preparados?) Não, não, emagine, não! Porque é uma coisa: ah! eu vivi nos Estados Unidos um ano, assi seis meses, mas isso não quer dizer que você fala o máximo, que você sabe tudo, não! De jeito nenhum. Que tem que saber tudo; acho que tem que estudar, assi [...] (História do país, origem das palavras) isso. Eu acho isso, que tem que estudar mais, tem uma de $F[. .$.$] graduar de uma Escol$ [...] uma Faculdade que ensine o idioma. Assi estudar só lá no "Wizard", assi um ano, dois anos, depois vocé viaja dois meses, assi não, esse/assi não dá para ficar lá ensinando tudo, porque você fica ensinando mal e acho que isso é só para dinheiro, mesmo, não é? $\mathrm{E}$ essas muitas escolas parece que só querem dinheiro, que cobram muito, e [...] mas não ensinam nada, então pegam qualquer pessoa.

(Está estudando Português? Está gostando? O que precisa ser ensinado?) Tô. Tô si. Que eu preciso aprender mais? Eu acho que é a pronúncia, que eles não ensinam assi falar mesmo como a "r", falar cachorro; e ensinam falar a "r", a "ão" como São Paulo e a "l", legal, né? a olha, coisas assi, que é difícil demais para a gente.

(E a respeito de temas?) Uhm [...] mais coisas, mais pra cultura, assi coisas como festas, assi, coisas culturais assi, como, sei lá, 
candomblé, coisas assi futebol também. Também música, não é? Que sempre é bom você comensar bater um papo com música, legal. Também política, também, porque você sempre pode falar sobre política, né? Um pouco, coisas assi.

(Cite alguma coisa sobre vocabulário) Talvez [...] acho que uma combinação; falta palavras, mas acho que falta gíria, assi: "idiomatic expressions" esse de feitos [...] frases já feitas, assi maneiras de expressar, coisas assi que [...] que todo mundo fala como, sei lá, não [...] não posso pensar em nada mais.

(E sobre "lyrics"?) Inglês? Não. Assim como? Mas de qualq [...] qualquer co [...] Ah! Torry Eimals. Inglês. Linda demais. Porque muito espiritual. Ela explora a alma humana, que acho lindo demais.

(E a Madonna? Você gosta dela?) Gosto sim. É [...] ein [...] ela, ela é um pouco mais superficial, que a lírica dela não é boa, mas eu sempre gostava dela, não sê, porque quando eu era criança, comecei a escutar a música dela, assi "Like a virgin" e crescia com ela e gostava porque ela foi muito rebelde e ele [...] ela falava contra a sociedade; ela fazia 0 que ela queri [...] ela queria; ela, muitas vezes, só fazia escândalo, mas eu nem acho que as coisas que ela [...] sempre queria, por exemplo, essa de [...] ess [...] essa, né? muito sexo, assi, sexo duro, coisa assi. Eu duvido que ela realmente faça essas coisas; acho que foi um show, sim, para fazer as pessoas pensar um pouco, que lá nos Estados Unidos a sexualidade é mais fechada que no Brasil. Acho que ela fazia isso para abrir as mentes das pessoas, para aceitar mais, coisas assi e por esso gosto dela. A música, tudo bem, né? mas prefiro mais do espírito dela que ele sempre vai lá em frente, lá em frente com as idéias, com a maneira de expressar.

(E aqui no Brasil?) Aí! Paulinho Pedro Azul, nordestino, conhece? Ah! é demais essa música, esse [...] esse cançon sobre falso carinho, lembra? Sobre falso carinho; ai, amo essa canção. (Por que?) Ah! porque é mui [...] verdade, não é? Tem muito carinho falso, acho eu. Ele falou não machuca quando você aprende; não é? E a outra é pra essa canção que "todo mundo quer voar nas costas deste beija-flor". Amo essa canção.

(Você se preocupa muito com a falsidade das pessoas, não é?) Demais, demais. Porque fui muito machucada por brasileiros. Já era. Nos Estados Unidos conheci muitos brasileiros e comecei a namorar com um brasileiro sin saber nada da cultura, asi. Só um pouco, né? $\mathrm{Na}$ Faculdade quando eu comeci [...] comecei a estudar Português. Ele me machucou demais; quebrou meu coração. Fui muito inocente; não sabia esse de malandragem, coisa assi. E o Brasil tem muito malandro. Ele foi muito falso comigo e foi muito, muito mal, inclusive que eu era amiga de todos os amigos deles que chegavam lá, não falavam Inglês, então foi 
muito ajudado, vai pra supermercado ajudar fazer compras, coisas assi, que eu fazia não bom, não é? porque queria ajudar, assi; quando a gente parou de sair, não é? Ele foram embora; nem olhavam para mim, nem queriam saber de mim, nem queriam falar oi?, nem, nem nada; machucou demais essa falsidade e depois outros 


\section{3 - FELICE - Nevada (EE.UU)}

Eu falo Espanhol, mas não é um Espanhol assim Espanhol da Espanha e México e Argentina. Eu aprendi falar Espanhol no Paraguai. Então eu falo um Espanhol Guaraniol. Eu falo mais Guarani que Espanhol de que Português.

Nossa todo todo; eu gosto demais estudar. Eu estudei [...] - Lá nos EE.UU eu estou estudando Nacionais e Internacionais e por esso aqui no Brasil eu estou estudando Antropologia. Conhecer a cultura brasileira, línguas brasileiras?, assi mais cultura.

Eu esteve - estou aqui sete semais. Eu veio para Brasil porque eu estou estudando América Latina. Para estudar América Latina hai que conhecer as duas lados: a da Espanhol e da Portuguesa.

Eu estudei Flauta. Mais a coisas esportistas. Eu sou esportista. Eu esqui quase todo dia de vida inteira. Eu fiz equitação - quase dezesseis anos e da natação eu fiz muitas muitas competições - quase toda minha vida eu tinha que estar na água às seis da manhã.

Nossa, claro a língua - é difícil, mas já consegui. Eu entendo tudo eu falo assi meio Portinhol, mas já pacência.

Eu vou ficar um ano e se eu consigo matricular no USP o ano que vem eu vou ficar mais tempo.

Nossa, os fanáticos de futebol. Eu conheço lá no Paraguai todo mundo fanático assim. Mas eu tinho um sorte fenominal estar aqui durante o - Copa do mundo e eu acho que uma coisa interessante porque não só fanáticos de futebol, mas da Xuxa, carneval; [...] é impressionante.

Eu sempre fosse [...] fui aventureira. Eu falo com mio mãe na Internet e com minha família lá, mas [...] Eu estou aqui só um año até agora eu seu que eu estou aqui um año só, por esso non é tempo para ficar com sodade; claro que algumas vezes lembro da coisas, mas já tranqüila, paciência [...] um año.

Tudo é diferente [...] a semelhança é que eu estou com outros espécies humanos, mas da cultura, da comida, da temporada [...] Nossa, quando eu saí dos EE.UU estava nevando na minha casa. E aqui faz um calor, um quinte que fenomenal.

Ai no meu quarto estudando. Fico lá vinte e quatro horas a dia.

Brasileiro ama su país, brasileiro ama su futebol, brasileiro ama su cafezinho [...]

Beijos - eu adoro beijos - não es fácil percibir é que não existe forma ninguna a primeira vez que eu sai os Estados Unidos que eu viajei a estrangeiro, eu conheci Paraguai. Nossa Senhora ichi Maria não é nada aqui no Brazil que pode ser tan estranho como lá no Paraguai.

Aqui no USP eu fico boba como todos os estudantes têm interessa 
na matéria. Lá nos EE.UU tem essos alunos que são interessados, mas aqui todo mundo tem um coragem para aprender, ficar [...] sempre tan perguntando coisas sobre esso, e esso e, esso [...] é impressonante.

(Perigosa) Depende esso também é um questión de que se a pessoa é novinha.

Eu conheci Paraguai e me conteci coisas que perigosíssimos. Mas hai sempre hai que estar alerta né - sempre hai que estar olhando as cosas. Não é como lá onde a policia som policia performados. Hai que tomar cuidado, claro!

O tempo - feo - feo - feo - assim da manhã faz um frio finominal e da repente pois uma duas horas um calor, um quinte.

São Paulo não é Brasil. São Paulo é São Paulo. Resto do Brasil é outra coisa, né?

Aqui no São Paulo é São Paulo. Se não fosse e citar eu não vou conseguir aproveitar a cultura. Não é critico - claro que hai coisas que me dam raiva que [...] ah. Tráfico - questión da trânsito - esso - claro, claro, claro, mas já pacência é São Paulo.

Não fosse São Paulo se não fuera por coisas assim, né?

Todo mundo sabe que F. H. vai ganhar mas é um questión de que ele vai ganhar por $1^{\circ}$ (turno) [...].

E questión de governador é um vergonha. São três mas ninguém serve. Aqui em São Paulo tem tan puder - São Paulo ano passado 200 bilhões dollares fueram investados no São Paulo - cidade São Paulo.

$E$ aqui temos Maluf que é um fanático mas ele fala de qualquer cosa mas não lembra di a próxima.

Rossi mas Rossi como evangelista tem um pouco méruco. Ele tem uns ideas que eu acho não vai servir para nada [...].

Eu não tenho nada que falar desso. Eu sou Americana. Nossa Eu to só que eu tinha visto.

(mensagem) $80 \%$ do poblação é considerada pobre, mas pobre dimais. Só 15 que são classe média e 5 classe que é população alta alta, né?

Você tem um país riquíssima - o da cultura da gente, da população e da coisas da natureza, mas como faz pouco tempo que Brasil conhesque a democracia. E já sei que eu sou assim totalmente imperialista dos EEUU, mais há que tomar cuidado porque estamos entrando no siclo XXI e assi a gente não pode conseguir aceptar o mercado global, aceita a educação por todo mundo, como na favela - já se que é algo feo, feo, feo. Mas, há que aceptar, há que faz força para mudar, né? É difícil. É todo uma questión da cultura também que o favela. Deus quise assi, já pacência, mas estamos entrando em mercado global, né? Com $80 \%$ do população que quase [...] quase alfabetizado, mas tudo não serve para nada. 
Como aqui estamos no tempo de eleições e até $80 \%$ vai votar, mas vai votar se saber nada de que está votando. Eu me parece um vergonha como $80 \%$ do população não sabe como leer. Aqui é queston de vamo votar mais e para quem porque não sabe nada de nada ai um vergonha.

(Conselho) Uma coisa só: hai que ter paciência.

(Curso de Inglês) É um bobagem, bobagem demais. Qualquer pessoa; Ah quero aprender Inglês. E vai estudar assi seis semanas não consegui nada. Se você quer aprender um idioma há que estudar, há que estudar direitinho por lo menos uma hora a dia - por dia. Assim qualquer pessoa que fala Inglês pode ter um des coisinha de Inglês, mas ninguém vai aprender meior oportunidade - aportunidade aprender idioma - outras línguas - vai estudar lá mas es todo um queston de dinheiro e poder e isso já entendo totalamente, mas a question de curso de Inglês aqui no Brasil é um absurdo.

(E sobre curso de Português?) Nossa eu adoro. Eu sei que eu não falo super bem, mas eu esteve - eu estou aqui sete semães e já está estou falando Português - eu acho que to bom, né? Eu adoro, eu apaixonei com a professora aqui com o grupo - somos quatro - todo mundo fala, todo mundo gracinha.

(O que falta?) Tempo. Não é nada que me falta. Eu acho que é um queston da pecência do tempo, como já eu consegui falar Português, mas é todo queston de como coisas da gíria - essa a gente aprende na rua, né? Aqui na aula a gente vai aprende como falar direitinho se forma, mas na rua é onde a gente aprende falar assi brasileiro, brasileiro. Eto eu acho.

Eu estou aqui para conhecer a cultura o que é/ e qual é a cultura? Cultura é Antropologia. Eu posso estudar Economia, mas Economia vou estudar coisas internacionais; é question da Antropologia eu sei que eu vou aprender coisas - eu vou tocar, eu vou saborear; vou ter conhecimento de coisas culturais aqui no Brasil.

(Brasil?) Porque eu estou aqui estudando América Latina.

Já passei tiempo na Paraguai. A volta eu vou astudar no Chile, mas a quem estudar no Brasil? Seria ridículo que eu possa dissir ah se eu conheço América Latina e nunca passei nenhum forma de tiempo aqui no Brasil.

Diverte. No hai tiempo para diverter-me. Eu fico lá estudando o dia inteiro.

- O sistema de coreo funciona. Esso só. Estava falando da cosa totalmente diferente. Eu não posso dissir que lá melior que aqui. Estamos falando de outros mundos. Eu não posso dissir nada di isso. Seu eu não pusei aceitar esso já está paciência sair do país. E eu estou aqui no Brasil estudando Brasil. Se eu quero estudar Estados Unidos já 
está eu moro lá.

Nossa (?) ah gente! Eu adoro o Brasil. Mas aqui no São Paulo como todo mundo trabalha, viva para trabalhar. Eu acho um absurdo, assim São Paulo totalmente industrializada, europeizada. Todo mundo coriendo. Todo tem que ser terminado ontem.

Eu quero estudar lá no Salvador onde todo pode esperar até amanhã e si non até semana que vem. Eu acho que a vida seja um poco mais tranqüila, que a gente não tinha tantas problemas da saúde se não fora - fosse a poluição, question da agitação, eu acho.

É uma pena porque assi Brasil tan lindo e da repente un cidade assi grande, perículo, da poluição e todo mundo agitado.

(Você tem religião?) Eu não.

Depende da persoa. Como eu sou uma [...] eu sou câncer, eu sou chorona qualquer ser eu vou chorar.

Eu preciso um "vai ser forte" para funcionar/continuar. Eu preciso um cassa, um família que ligará porque é forte. Aqui no São Paulo eu consegui sorte - Graças a Dios. Eu sei que eu non tenho religion mas graças a Deus. Eu conseguio um família maravilhosa. Eu vá ser forte onde eu posso sair daí e sabendo que qualquer cosa me acontece eu tenho um lugar para voltar.

Rio. Rio. Mas eu tivê lá poco tiempo. No se, esto é uma coisa bruta ninguém teve forma hot, né? (fomos interrompidos de forma brutal).

Ah! Eu quero disser que eu fico brava mas estava falanda da cultura. Seu eu vou a conseguir funcionar aqui no Brasil eu tenho que acitar a coisas assi. A respeito o espaço profissional aqui no Brasil não existe, forma ninguma. Se você não acha esso, proveita tomar, pegar um ônibus, né? Aqui no Brasil, coisas assi os duos homens - duos moços entrou assi todo professional como tien algo que fazer importantíssima e que fizeram? Tomaram a altura da janela no sê quer algo bobage, mas aqui na janela. Aqui em esta sala a janela é igual que qualquer outra janela de edifício. Porque entrar aqui? Com gente que a porta fechada, né?, fechada. Com qualquer há que resolver aqui outro a sala que tá totalmente a ver com ninguém falar (tá lá). Por que há que entrar aqui?

Beleza natural, mas você sabe como é aqui em Brasil que você tem você deixa agradesco Ihes deram, Ihe apresentaram um beleza fenomenal. Mas a ver que tá passando lá no parque Ibirapuera. Todos os peixes está morta, né? Que beleza né? Que beleza fenomenal! Puxa, nossa Senhora! Os rios. Eu ando a casa. Eu cruzo o rio Pinheiros todo dia duas vezes, faz uma semana eu tava cruzando e da repente, né? Por que é? Puxa! Foi um vaca. Mas foi metade um vaca, cabeça e o perna, né? Mas total velha, velha, deve ser que é de vaca muerta sabe lá não sei quanto tempo não sei se no que vocês mudam dirigindo ou 
que tá um trânsito que cruza pelo rio mas é algo Nossa Senhora Vixi Maria.

Acho que o mundo tem pouco paciência. Quando eu cheguei aqui a primeira dias, ah! Somente saí com mia mãe, a minha mãe hospedeira, mas ela é mia mãe. E da esso todo mundo me conhecia lá perto da mia bairo, lá farmácia ah americana, tudo bem? Gente me fala Inglês, todo bem, paciência, lá na padaria todo, mundo lá me conhece como Americano. Oh Americana.

Eu qual time melhor, Corinthians? Eu tenho que responder: não, São Paulo, São Paulo. Todo mundo já gracinha.

Moro com minha mãe.

(Morar sozinho) Depende totalmente da personas. Haí personas que son totalmente independente lá da sociedade já esta. Hay outros que precisam não sei que por que ni como mas precisam gente para brigar. Ficar assi poco agitada, nervoso, non funciona fora da sua identidade e por esso pegam ao lado de alguma persoa.

(No Paraguay) Um ano. Eu fui idade de 15 anos. E fuera um prazer fico.

Qualquer cidade maior grande do mundo hay perigro, e por esso a gente sempre tem que tomar cuidado, juízo, estar alerta, porque estamos é/a 20 milhões das pessoas e hay mito probeza aqui, probeza é uma forma da, é um semente da violência, né? Hay que tomar cuidado. Eu sê/sei que não vou andar sozinha nun favela, mas depois da 9 e meia da noite não vou tomar, pegar ônibus. Hay que tomar cuidado, hay que estar alerta. A gente pode funcionar, existir aqui no São Paulo, mas com inteligência.

Expressão americana não é tan lindo como expressão Guarani.

Eu acho que [...] é gracinha - todo mundo asi - olá, brother! Como vai? Esso gracinha, gracinha. Mas eu acho que Guarani é melior.

Vou voltar para os EE.UU. Se eu consigo um bolsa vou estudar a Universidade Católica no Chile. Se eu não consigo já paciência, vou trabalhar, ganhar mais dinheiro e com esso vou estudar no Chile.

Aqui no Brasil eu estou estudando, eu sou estudante.

Tenho duas [...] um irmão mais um irmã. Estan lá. Meu irmão está estudando Física e Filosofia. Este - um combinação um pouco rara, já paciência. Minha irmã - ela iva ser famosa. Ela está entrenimiento para esquiar. Ela vai [...] di inverno que vem o próximo que vem. Agora ela está si entrenimientos.

Puxa, eu estou tan feliz, já se que não é feliz; por esso eu sou feliz, mas eu estou feliz. Aqui no Brasil eu estou conseguiendo cosas maravilhosas: amigos, gente boa, coisas do means; eu estou conhecendo cafezinho, io nossa, nossa, chá, café nos Estados Unidos $[\ldots]$. 
Ae! Os cantores. Eu fui assistir de Caetano Veloso no parque Ibirapuera. Não vi nada mas gostê. Eu posso dessir que eu estava lá Música Brasileira é gostoso. Eu adoro. Eu tinha uma aula de música popular do Brasil que ficou um pouco duro, com gente falou dos anos sessenta, da Al cinco o question da falar contra govierno com música e coisas da arte e lá esso os brasileiros conseguiram um basse na [...] da música que é forte aqui no Brasil. A música tem um significado importante no brasileiro. Ah Eu adoro, samba, Nossa Senhora, eu adoro. Pagode.

(A Madona merece toda essa fama?) Sei lá, tabém, tabém. Madona é uma madona, né?, assi italiane, bambina. Ela é inteligente esso claro, claro, claro. Ela é inteligente. Eu tinha o vivo entrevistas com ela e eu fiquei meio boba com ela [...] da música não parece tan inteligente e como ela nunca estudar no Faculdade não tinha assi cultura, question na educação, não o que educação como "manneris", mas educação como estudos. Mas ela tem um cabeça que funciona.

Como faz, nossa! Faz uma semana. Tem um música aqui. Ficar na minha cabeça que eu não posso tirar, e [...] mas eu não sei nada, somente duas palavras. No sê di que e ni nada, mas é [...] preciso de você [...] e não sê como fica mais assi [...] como uma semana eu tenho essas duas líricas, duas palavras só. Assi ficar na minha cabeça.

Eu [...] não, não nos Estados Unidos, não, acho que não espera. Não sê [...] tan pouco.

Ai! Foi um cantor que foi lançado a [...] como uma semana acho que eu saí dali. Que foi [...] foi um filme que um filme, como se chama, no me lembra o nome do filme, mas era um pouco gracinha: um govierno, um governador lá no quiso ser governador da classe alta e já quiso tomar um [...] assi um, a cultura [...] a cultura negra da [...] dos Estados Unidos. Da ripente um canción foi escrito pra aquele inferno, que tem um lírico super, super - gracinha porque etá falando da alguém [...] da cultura, da [...] da classe alta, né? E os líricos são [...]

"Get a super-star, that is what you are" (começa a cantar alguns versos em Inglês) e que significa:

Aquela criou num favela, né? [...] e um super-star com super - não sê como [...] estrela super, né? [...] i me parece um pouco gracinha.

Eu estava [...] iva falando porque como eu sou estudante pobre, que eu tenho que trabalhar e como [...] se eu conseguia, quero ir trabalho em [...] na hípica porque eu com dezesseis anos eu andei [...] E para [...] como eu não consegui bolsa estudar aqui no Brasil, eu tinha que vender meu cavalo, mas foi uma cosa [...] ai [...] eu tenho lágrimas de esso, eu vou ficar assi um pouco trista. Lá nos Estados Unidos meu cavalo eu esteve com [...] eu sempre esteve com ele como três horas a dia e da ripente dentro uma mês, um mês para vir/ver por aqui no Brasil 
eu vou vender ele para conseguir dinheiro suficiente estudar aqui no Brasil. Então eu vendi. Mas também eu tenho uma história tem/assim um pouco gracinha. Eu estive, eu sempre estou falando com minha mãe aqui no Brasil. Que eu tenho tão saudade da mio cavalo [...] é estranho [...] ele, ai nossa, como quero ver-la. Ela consiguiô um direción de um fazenda aqui/que tem cavalos para alugar. Eu fui. Nossa Senhora Ishi Maria. Fuê uma coisa [...] Eu fiquei doente, eu fiquei doente da saudade e da lástima. Lá os cavalos eram magros, doente, tem brilhos e o dono era do interior, de Minos Gerais; ele era uma artista demais e como aqui eu sou uma Americana magrinha, assim jovem, tan mulherzinha. "Eu quero andar cavalo" - Este sinhor ficou - ele não falou comigo, não me mirou, não me falou direito. Ela falou com um senhor que me levou. $E$ ele foi um artista dimais mas eu [...] Eu fui procurar o um cavalo que eu quiser andar. Eu coloquei o mais gran [...] o mais melior do estava/estábulo, né? Não sê consegui esso, mas [...] Eu quero andar a esta. "Mas, não", porque ela é brava; ela não posso, não pode [...] não deixa. Eu quero andar a esta".

Da repente - num cila, cel [...] cila [...] coisa onde [...] cila - aquele negócio onde [...] eu quero [...] fico no cavalo bom; então eu disse: deixa, deixa. Mas o senhor ficou [...] Não, essa menina, ela não pode, ela não sabe nada; não é como os filmes americano. O West - nada é assim. Não é como quando isto, nada, nada.

Eu: não, deixa, eu sei como, eu tenho saudade; somente quero assi tocar o cavalo, quero andar pouquinho. E, bom, o cavalo, o cavalo fuê brava; ela ficou assi totalmente agitada; quiso correr até não sei onde mais. Foi super, super divertido. Eu fiquei lá todo, todo gracinha.

De repente, quando eu voltei para o estavo/estábulo, o senhor estava lá. Ele ficou bobo; ele não podria dizer nada. Como, Nossa Senhora, esta/essa menina sabe como andar. E eu fiquei assi tan orgulhosa.

(Fez equitação nos EE.UU?) Si, dezisseis anos. Dezesseis anos eu sempre, eu teve fazendo esto. Eu acho que é uma coisa maravilhosa; eu sei que una [...] um esporte da riqueza; esso já paciência; mas eu traveio muito. Eu tinha travaiodo muito para pagar para meu cavalo. Meus pais nunca me ajudaram com o coisa da cavalo, o coisa [...] depois estudos, né? Mas eu tinha [...] una adictação - addiction - fuê [...] eu tinha doze anos e eu conheci o savor quando os dos cabeças funcionam juntos. Como eu tengo dentro mia cabeça, tengo tanta preocupas porque eu salto.

E com, [...] Ti [...] , tal altura, assi, no sê, será que vamos chegar por outro lado, coisas assi. Imaginar como é para o cavalo e quando os doas cabeças funciona juntas, alguma coisa maravilhosa; é um sabor melhor que chocolate, já está pico/fico lá. Está cierto, siempre amei e, 
por esso, fui aquele fazenda, porque eu tinho saudade eu quiso saborear, eu consegui, eu fiquei feliz, né?

(Pretende voltar a um haras?) No sê. Demais eu quero conhecer a uma persoa que me pode, não sei, indicar [...] como para conhecer a hípica, porque lá é como eu fez: assi [...] equitaçón clássica da [...] da [...] da [...] não é assi como fazenda, qualquer cavalo magro, doente não! Assi, cavalos altos, forte, educados, né? Essos que eu gosto. Mas, como [...] é super difícil e também eu estou aqui somente por um año, já paciência; posso voltar, faz de novo, né? 
ANEXO D - Tabela De Correspondências (interlíngua e língua 2)

1 Dificuldades relativas aos substantivos

\begin{tabular}{|c|c|}
\hline Interlíngua & Língua 2 \\
\hline Gente tem mais paz. & As pessoas têm mais paz. \\
\hline $\begin{array}{l}\text { Para fazer mais ligações como fazem } \\
\text { outros partes, incluindo a Inglaterra. }\end{array}$ & $\begin{array}{l}\text { para fazer mais contatos como fazem } \\
\text { outras partes do mundo (outros } \\
\text { países), incluindo a Inglaterra. }\end{array}$ \\
\hline Mas esso é uma parte de Consulado & $\begin{array}{l}\text { Mas isso é um problema (uma } \\
\text { responsabilidade) do Consulado }\end{array}$ \\
\hline $\begin{array}{l}\text { Uma parte de Consulado como ter mais } \\
\text { conhecimento da Inglaterra. }\end{array}$ & $\begin{array}{l}\text { um problema do } \begin{array}{l}\text { Consulado } \\
\text { despertar mais } \\
\text { Inglaterra. }\end{array} \\
\text { Ingleresse pela } \\
\end{array}$ \\
\hline $\begin{array}{l}\text { (propriedade público) como os calçados, } \\
\text { os buracos no rua. }\end{array}$ & $\begin{array}{l}\text { (propriedade pública) como as } \\
\text { calçadas, os buracos na rua. }\end{array}$ \\
\hline Outras áreas além do trabalho $[\ldots]$ & outras atividades além do trabalho $[\ldots]$ \\
\hline $\begin{array}{l}\text { é difícil entrar na coração da alma } \\
\text { brasileira }\end{array}$ & $\begin{array}{l}\text { é difí́il } \begin{array}{l}\text { entrar no fundo da alma } \\
\text { brasileira } \\
\text { ir até o fundo da alma } \\
\text { brasileira }\end{array} \\
\begin{array}{l}\text { (entender o que se passa na alma } \\
\text { brasileira) }\end{array}\end{array}$ \\
\hline a administração deste tipo de arranja & $\begin{array}{l}\text { a administração deste tipo de } \\
\text { organização (sistema de Governo) }\end{array}$ \\
\hline $\begin{array}{l}\text { Mas } \frac{o \text { político de nosso Governo }}{\text { (Inglaterra) }} \\
\end{array}$ & $\begin{array}{l}\text { mas a política de nosso Governo } \\
\text { (Inglaterra) }\end{array}$ \\
\hline $\begin{array}{l}\text { Trabalho sem "disturbance", } \\
\text { dificuldades, juntos com viver } \\
\text { dificuldades }\end{array}$ & $\begin{array}{l}\text { trabalho sem perturbação, sem } \\
\text { dificuldades, (além de) assim como } \\
\text { viver sem problemas }\end{array}$ \\
\hline Nosso trabalho 0 coisas da alfândega & $\begin{array}{l}\text { nosso trabalho com os serviços da } \\
\text { alfândega }\end{array}$ \\
\hline
\end{tabular}




\begin{tabular}{|c|c|}
\hline $\begin{array}{l}\text { O problema é na aula de alunos: um } \\
\text { pouco de modo, este }[. . .] \text { verbos. }\end{array}$ & $\begin{array}{l}\text { O problema está na aula com alunos: } \\
\text { um está no ensino dos modos, este } \\
\text { (problema que ocorre com as formas } \\
\text { variadas dos) verbos. }\end{array}$ \\
\hline $\begin{array}{l}\text { Não dá para assimilar como um trabalho } \\
\text { o resto aqui }\end{array}$ & $\begin{array}{l}\text { Não dá para assumir como um trabalho } \\
\text { o restante das coisas aqui }\end{array}$ \\
\hline Dá para voar em todo o parte do mundo & Dá para voar por toda a parte do mundo \\
\hline Eu tem muito que eu gosto de Brasil & $\begin{array}{l}\text { Existem muitas coisas de que eu gosto } \\
\text { no Brasil }\end{array}$ \\
\hline $\begin{array}{l}\text { Eu e minha família ainda não sufre } \\
\text { algumas turmas de violência }\end{array}$ & $\begin{array}{l}\text { Eu e minha família ainda não } \\
\text { enfrentamos nenhum grupo de } \\
\text { assaltantes }\end{array}$ \\
\hline $\begin{array}{l}\text { É muito mais difícil do que nossos na } \\
\text { Inglaterra }\end{array}$ & $\begin{array}{l}\text { É muito mais difícil do que nossos } \\
\text { trâmites na Inglaterra }\end{array}$ \\
\hline Conhecendo lugar desde o ar & $\begin{array}{l}\text { Conhecendo lugares lá de cima (lá do } \\
\text { alto) }\end{array}$ \\
\hline $\begin{array}{l}\text { Então renovar esta burocracia para } \\
\text { seletar a educação de estrangeiros no } \\
\text { Brasil }\end{array}$ & $\begin{array}{l}\text { Então aperfeiçoar esta burocracia para } \\
\text { facilitar a adaptação de estrangeiros no } \\
\text { Brasil }\end{array}$ \\
\hline$\frac{\text { Os homens de negócio }}{\text { passam muito tempo achando uma casa }}$ & $\begin{array}{l}\text { Os estrangeiros, homens de negócio, } \\
\text { passam muito tempo para achar } \\
\text { (procurando) uma casa (para alugar ou } \\
\text { comprar). }\end{array}$ \\
\hline $\begin{array}{l}\text { Curiosamente os bancos, esses }[\ldots] \\
\text { coisas de seguro, outro tanto } \\
\text { conhecimento de Inglês }\end{array}$ & $\begin{array}{l}\text { curiosamente os bancos, com essas } \\
\text { coisas (assuntos) de seguro, e outras } \\
\text { coisas do tipo (semelhantes) exigem } \\
\text { conhecimento de Inglês }\end{array}$ \\
\hline $\begin{array}{l}\text { o sucesso aulas de Inglês }[\ldots] \text { para } \\
\underline{\text { encontrato outros alunos }[\ldots]}\end{array}$ & $\begin{array}{l}\text { o sucesso das aulas de Inglês para se } \\
\text { conseguir (obter) inscrição (ou } \\
\text { matrícula) de outros alunos }\end{array}$ \\
\hline Eu estudei a português Londres & Eu estudei Português em Londres \\
\hline $\begin{array}{l}\text { Eu parei de estudar quando passa uma } \\
\text { prova, uma coisa de nível intermediário }\end{array}$ & $\begin{array}{l}\text { Eu parei de estudar quando ela passou } \\
\text { uma prova, uma prova de nível } \\
\text { intermediário }\end{array}$ \\
\hline Existe uma precisa de mudar os coisas & $\begin{array}{l}\text { Existe uma necessidade de mudar as } \\
\text { coisas }\end{array}$ \\
\hline
\end{tabular}




\begin{tabular}{|c|c|}
\hline Pode ser um gosto muito bom & Pode ser uma coisa muito agradável \\
\hline Você não uma sistema regular & Você não tem uma sistemática regular \\
\hline $\begin{array}{l}\text { Você tem uma relação muito simpático } \\
\text { com uma funcionário da aeroporto }\end{array}$ & $\begin{array}{l}\text { Você tem um relacionamento muito } \\
\text { simpático com um funcionário do } \\
\text { aeroporto }\end{array}$ \\
\hline Eu tenho um processo da alfândega & $\begin{array}{l}\text { Eu tenho um processo (problema) na } \\
\text { alfândega }\end{array}$ \\
\hline $\begin{array}{l}\text { Aqui todas as pessoas dos funcionários } \\
\text { do governo mudam também }\end{array}$ & $\begin{array}{l}\text { Aqui todos os funcionários do } \\
\text { governo mudam também }\end{array}$ \\
\hline $\begin{array}{l}\text { Nós temos um relação com muito } \\
\text { sucesso }\end{array}$ & $\begin{array}{l}\text { Nós temos (tido) relacionamento com } \\
\text { muito sucesso }\end{array}$ \\
\hline $\begin{array}{l}\text { Mas é tan pequenho parte }[. . .] \text {, mas }[. . .] \\
\text { de novo, é significante }\end{array}$ & $\begin{array}{l}\text { mas existe uma parte tão pequena, } \\
\text { mas [...] volto a dizer, é significativa } \\
\text { (merece atenção) }\end{array}$ \\
\hline $\begin{array}{l}\text { O Conselho Britânico tem um policia do } \\
{[\ldots] \text { mudar as pessoas }}\end{array}$ & $\begin{array}{l}\text { O Conselho Britânico tem uma política } \\
\text { de mudar as pessoas (de mudança do } \\
\text { pessoa) }\end{array}$ \\
\hline$\underline{\text { O ambiente está uma início do escola }}$ & A época é de início das aulas \\
\hline Uma ambiente do poucas $[\ldots]$ & Uma época de poucas folhas (flores) \\
\hline $\begin{array}{l}\text { Francisco Weffort, o } \underline{\text { Ministério }} \text { da } \\
\text { cultura, }[\ldots]\end{array}$ & $\begin{array}{l}\text { Francisco Weffort, o ministro da } \\
\text { cultura, }[. . .]\end{array}$ \\
\hline$\frac{\text { os povos }}{\text { interessante }}$ têm uns idéias muito & $\begin{array}{l}\text { as pessoas têm (umas) idéias muito } \\
\text { interessantes }\end{array}$ \\
\hline $\begin{array}{l}\text { os diplomáticos não está tramitado para } \\
\text { com os coletivo em detalhes, }[\ldots]\end{array}$ & $\begin{array}{l}\text { os diplomatas não estão preocupados } \\
\text { (atuando em favor) com os problemas } \\
\text { do povo em detalhes, [...] }\end{array}$ \\
\hline $\begin{array}{l}\text { todos os políticos têm o centro, talvez } \\
\text { direto do centro, esquerda do centro, } \\
\text { mas os políticos do } \\
\text { têm o mesmo situação }[. . .]\end{array}$ & $\begin{array}{l}\text { todos os políticos são de centro, talvez } \\
\text { de centro-direita, centro-esquerda, } \\
\text { mas os políticos de todo o mundo se } \\
\text { encontram na mesma situação [...] }\end{array}$ \\
\hline $\begin{array}{l}\text { E Clinton, por exemplo, ele é } \underline{0} \\
\text { democrático, mas ele precisa } \underline{\text { os }} \\
\underline{\text { pessoas "Republicans" }}\end{array}$ & $\begin{array}{l}\text { E Clinton, por exemplo, é um } \\
\text { democrata, mas precisa dos } \\
\text { Republicano }\end{array}$ \\
\hline
\end{tabular}




\begin{tabular}{|c|c|}
\hline $\begin{array}{l}\text { Nós fomos pra terra da rua, } \\
\text { supermercado, aeroporto }[\ldots]\end{array}$ & $\begin{array}{l}\text { Nós íamos para a calçada da praia } \\
\text { (areia da praia), supermercado, } \\
\text { aeroporto }[. . .]\end{array}$ \\
\hline $\begin{array}{l}\text { A filha }[. . .] \text { a menina do supermercado } \\
\text { não entende eu sou inglesa } \\
\text { e não tenho um sistema de cheque. }\end{array}$ & $\begin{array}{l}\text { A menina do supermercado } \\
\text { não entendeu (percebeu) que eu sou } \\
\text { inglesa e não tenho hábito de cheque } \\
\text { (de pagar com cheque). }\end{array}$ \\
\hline $\begin{array}{llll}\text { motoristas } & \text { do taxi } & \text { têm } & \text { bem } \\
\text { conhecimento da Londres } & & \end{array}$ & $\begin{array}{l}\text { motoristas de táxi têm um bom } \\
\text { conhecimento da cidade de Londres }\end{array}$ \\
\hline $\begin{array}{l}\text { Aqui uma pessoa com taxi não tem } \\
\text { nada }\end{array}$ & $\begin{array}{l}\text { Aqui um motorista de táxi não tem } \\
\text { conhecimento nenhum }\end{array}$ \\
\hline $\begin{array}{l}\text { Eu moro perto de Pacaembu - de } \\
\text { Estado de Pacaembu }\end{array}$ & $\begin{array}{l}\text { Eu moro perto do Pacaembu - do } \\
\text { Estádio do Pacaembu }\end{array}$ \\
\hline [...] O! experiência ! & $\begin{array}{l}{[\ldots] \text { Oh! Que sufoco! Foi uma boa }} \\
\text { (bela) experiência }\end{array}$ \\
\hline $\begin{array}{l}\text { Eu tinha a responsabilidade dos país do } \\
\text { América Latina }\end{array}$ & $\begin{array}{l}\text { Eu tinha a responsabilidade } \\
\text { (incumbência dos) pelos países da } \\
\text { América Latina }\end{array}$ \\
\hline Eu tinha uma sentido isolação & $\begin{array}{l}\text { Eu tinha uma sensação de isolamento } \\
\text { (Eu tinha um sentimento de solidão = } \\
\text { sentia solidão) }\end{array}$ \\
\hline Eu me sinto estúpido & Eu me sentia uma idiota \\
\hline Foi muito difícil ter uma reunião fácil & $\begin{array}{l}\text { Foi muito difícil presidir a uma reunião } \\
\text { com facilidade } \\
\text { (Foi muito difícil comunicar-me durante } \\
\text { uma reunião com facilidade) }\end{array}$ \\
\hline $\begin{array}{l}\text { As pessoas que têm um talento das } \\
\text { línguas, não está as pessoas melhores } \\
\text { ensaia língua. }\end{array}$ & $\begin{array}{l}\text { As pessoas que têm conhecimento de } \\
\text { línguas (facilidade para línguas) não } \\
\text { são (necessariamente) as melhores } \\
\text { para ensinar (uma língua). }\end{array}$ \\
\hline $\begin{array}{l}\text { Eu acho que se eu tinha o tempo, eu } \\
\text { gostaria escrever uma livra: "Language } \\
\text { for clutches" }\end{array}$ & $\begin{array}{l}\text { Se eu tivesse tempo, eu gostaria de } \\
\text { escrever um livro: "Língua e os } \\
\text { caminhos adequados para } \\
\text { aprendizagem". } \\
\text { (Eu gostaria de, se eu tivesse tempo, } \\
\text { escrever um livro: [...]) }\end{array}$ \\
\hline
\end{tabular}




\begin{tabular}{|c|c|}
\hline $\begin{array}{l}\text { Como aprender uma língua se você não } \\
\text { tem talento da língua? }\end{array}$ & $\begin{array}{l}\text { Como ensinar uma língua se você não } \\
\text { tem competência didática? (não sabe } \\
\text { ensinar a língua) } \\
\text { (Como aprender uma língua se você } \\
\text { não tem facilidade para línguas?) }\end{array}$ \\
\hline $\begin{array}{l}\text { Os pessoas que têm o talento da língua } \\
\text { não têm o imaginação por pessoas como } \\
\text { eu }\end{array}$ & $\begin{array}{l}\text { As pessoas que têm habilidade para } \\
\text { línguas não têm capacidade de } \\
\text { perceber a limitação de pessoas como } \\
\text { eu }\end{array}$ \\
\hline Realmente as aulas não tinha um tema & $\begin{array}{l}\text { Realmente as aulas não tinham um } \\
\text { plano (de ensino) }\end{array}$ \\
\hline Eu me lembro o processo agora & $\begin{array}{l}\text { Eu me lembro de toda a seqüência (de } \\
\text { dificuldades) agora }\end{array}$ \\
\hline $\begin{array}{l}\text { Ah! eu não tenho talento dos línguas, eu } \\
\text { não tenho talento dos vivar estrangeiro }\end{array}$ & $\begin{array}{l}\text { Ah! Eu não tenho capacidade } \\
\text { (tendência) para línguas, eu não } \\
\text { tenho habilidade para viver no } \\
\text { estrangeiro }\end{array}$ \\
\hline $\begin{array}{l}\text { Você tem litoral muito lindo, os cidades } \\
\text { fenomenal, o Amazonas, o mundo } \\
\text { natural. }\end{array}$ & $\begin{array}{l}\text { Vocês têm (o Brasil tem), um litoral } \\
\text { muito lindo, cidades fenomenais, o } \\
\text { Amazonas, com todo seu ambiente } \\
\text { natural. }\end{array}$ \\
\hline $\begin{array}{l}\text { Como os cruzadas foram pra o rio } \\
\text { Jordão e travessa - eles tinha } \underline{0} \\
\text { permissão do rei de Fitzgerald - trocar a } \\
\text { nome da Jordão }\end{array}$ & $\begin{array}{l}\text { Como as cruzadas foram para a } \\
\text { direção do rio Jordão, na travessia } \\
\text { eles tinham por ordem do rei de } \\
\text { Fitzgerald trocar o nome para Jordão } \\
\text { (trocar seu nome pelo do rio; tornar } \\
\text { para si o nome do rio com a travessia) }\end{array}$ \\
\hline $\begin{array}{l}\text { Às vezes eu tenho frustração com os } \\
\text { telecomunicações. }\end{array}$ & $\begin{array}{l}\text { Às vezes eu tenho decepcão com as } \\
\text { telecomunicações. }\end{array}$ \\
\hline $\begin{array}{l}\text { Agora nós temos uma sistema de } \\
\text { telefonar muito bom }\end{array}$ & $\begin{array}{l}\text { Agora nós temos um sistema de } \\
\text { telefonia muito bom }\end{array}$ \\
\hline $\begin{array}{l}\text { Você não tem uma sistema do } \\
\text { transportivo público }\end{array}$ & $\begin{array}{l}\text { Vocês não têm um sistema de } \\
\text { transportes público(s) }\end{array}$ \\
\hline $\begin{array}{l}\text { Em Londres nós temos uma sistema } \\
\text { muito sofisticado, do maior do mundo. }\end{array}$ & $\begin{array}{l}\text { Em Londres nós temos um sistema } \\
\text { muito sofisticado, o melhor do mundo. }\end{array}$ \\
\hline $\begin{array}{l}\text { Quando uma pessoa de }[\ldots] \text { é possível } \\
\text { ter uma concorda verbal }[\ldots] \text { fica bobage }\end{array}$ & $\begin{array}{l}\text { Quando uma pessoa é responsável } \\
\text { (íntegra), é possível ter com ela um } \\
\text { acordo verbal, mas fica tudo sem }\end{array}$ \\
\hline
\end{tabular}




\begin{tabular}{|c|c|}
\hline [...] não tem preocupação. & $\begin{array}{l}\text { valor }[\ldots] \text { ela não tem preocupação } \\
\text { nenhuma. }\end{array}$ \\
\hline $\begin{array}{l}\text { São Paulo tem o festa do filmes jurídica } \\
\text { muito interessante. }\end{array}$ & $\begin{array}{l}\text { São Paulo tem o festival de filmes } \\
\text { para crítica dos mesmos, o qual é } \\
\text { muito interessante. } \\
\text { (São Paulo tem o festival, muito } \\
\text { interessante, para julgamento de } \\
\text { filmes). }\end{array}$ \\
\hline $\begin{array}{l}\text { Às vezes eu tenho saudades do }[\ldots] \\
\text { mudar os tempos. }\end{array}$ & $\begin{array}{l}\text { Às vezes eu tenho saudades da } \\
\text { mudança das estações. }\end{array}$ \\
\hline Nós temos quatro $[\ldots]$ mudar estações & $\begin{array}{l}\text { Nós temos quatro mudanças visíveis } \\
\text { (nítidas) de estações. }\end{array}$ \\
\hline $\begin{array}{l}\text { Cine Sesc tem uma seleção dos filmes } \\
\text { das artes. }\end{array}$ & $\begin{array}{l}\text { O Cine-Sesc tem uma seleção de filmes } \\
\text { de arte. }\end{array}$ \\
\hline $\begin{array}{l}\text { As pessoas do Conselho têm uma } \\
\text { programa do Português bom, Francês, o } \\
\text { Espanhol antes do viajando e depois da } \\
{[\ldots] \text { bem vai chegar você tem outro }} \\
\text { curso. }\end{array}$ & $\begin{array}{l}\text { O pessoal do Conselho tem um bom } \\
\text { programa de Português, Francês ou } \\
\text { Espanhol antes da viagem (vir para cá) } \\
\text { e depois de chegar eles têm outro curso } \\
\text { (o pessoal do Conselho). }\end{array}$ \\
\hline Dois filhos: filha, filho. & Dois filhos: uma filha e um filho. \\
\hline $\begin{array}{l}\text { [...] mas dentro o mesmo prédio a erma } \\
\text { da esposa. }\end{array}$ & $\begin{array}{l}\text { [...] mas no mesmo prédio mora a irmã } \\
\text { da esposa. }\end{array}$ \\
\hline $\begin{array}{l}\text { Eu tinho umas ou duas desastres no } \\
\text { supermercado com cheque primeiro vez } \\
\text { a línea. }\end{array}$ & $\begin{array}{l}\text { Eu tive algumas dificuldades [Eu } \\
\text { cometi alguns enganos (absurdos, } \\
\text { burradas)] no supermercado, na } \\
\text { primeira vez que preenchi um cheque } \\
\text { (quando fui preencher a linha do } \\
\text { cheque). }\end{array}$ \\
\hline $\begin{array}{l}\text { Perto do Hospital do Samaritano. } \underline{\mathrm{O}} \\
\underline{\text { mundo conheço. }}\end{array}$ & $\begin{array}{l}\text { Perto do Hospital Samaritano. Todo } \\
\text { mundo conhece. }\end{array}$ \\
\hline $\begin{array}{l}\text { Eu acho que ele cheguei [...] chegou do } \\
\text { entero - enterior do São Paulo. }\end{array}$ & $\begin{array}{l}\text { Eu acho que (parecia que) ele chegou } \\
\text { do interior de São Paulo. }\end{array}$ \\
\hline Eu senti muito estúpido. & Eu me senti uma grande idiota. \\
\hline $\begin{array}{l}\text { quando meu }[\ldots] \text { minha primeira vez } \\
\text { com um VIP. }\end{array}$ & $\begin{array}{l}\text { quando fui me encontrar pela primeira } \\
\text { vez com um VIP. }\end{array}$ \\
\hline Eu não sube sobre entra aero & Eu não sabia como entrar no aeroporto \\
\hline
\end{tabular}




\begin{tabular}{|c|c|}
\hline $\begin{array}{l}\text { Nós fomos pra aeroporto sabendo nado } \\
\underline{\text { conjunto }}\end{array}$ & $\begin{array}{l}\text { Nós fomos para o aeroporto mas } \\
\text { nenhum dos dois sabia (conhecia) } \\
\text { nada }\end{array}$ \\
\hline $\begin{array}{l}\text { Felizmento o menino da loja falou um } \\
\text { pouco Inglês }\end{array}$ & $\begin{array}{l}\text { Felizmente o vendedor falava um } \\
\text { pouco de Inglês }\end{array}$ \\
\hline $\begin{array}{l}{[\ldots] \text { quando vocêm fale Português tudos }} \\
\underline{\text { o dia com um pessoa }}\end{array}$ & $\begin{array}{l}\text { [...] quando a gente fala Português o } \\
\text { dia inteiro (todo o dia) com uma } \\
\text { pessoa }\end{array}$ \\
\hline $\begin{array}{l}{[\ldots] \text { até jantar nós fomos muito }} \\
\text { descansada }\end{array}$ & $\begin{array}{l}{[\ldots] \text { até no jantar nós ficávamos muito }} \\
\text { quietos (mudos) }\end{array}$ \\
\hline $\begin{array}{l}{[\ldots] \text { porque as pessoas do Brasil estão }} \\
\text { muito simpático com estrangeiros }\end{array}$ & $\begin{array}{l}{[\ldots] \text { embora os brasileiros sejam muito }} \\
\text { atenciosos com os estrangeiros }\end{array}$ \\
\hline $\begin{array}{l}\text { Sim. Eu tinha uma problema com } \\
\text { compreensão }\end{array}$ & $\begin{array}{l}\text { Sim. Eu tinha dificuldade para } \\
\text { entender (compreender) }\end{array}$ \\
\hline $\begin{array}{l}\text { Você vai aprender pelo falando, mas não } \\
\text { verdade }\end{array}$ & $\begin{array}{l}\text { Você vai aprender falando (através da } \\
\text { fala, pela fala), mas (isso) não é } \\
\text { verdade }\end{array}$ \\
\hline Eu acho que você precisa escutar & Eu acho que a gente precisa escutar \\
\hline [...] agora eu posso entendo as notícias & $\begin{array}{l}{[. . .] \text { agora eu posso entender as notícias }} \\
\text { (do rádio) }\end{array}$ \\
\hline $\begin{array}{l}\text { Eu ouço }[\ldots] \text { destaques: Manaus } \\
\text { parrrrrrrrr }[\ldots]\end{array}$ & $\begin{array}{l}\text { Eu ouvia notícias em destaque: } \\
\text { Manaus (usa sons para representar a } \\
\text { dificuldade de compreensão) }\end{array}$ \\
\hline $\begin{array}{l}\text { [...] mas eu acho que eu aprende } \\
\text { Português da rua com os lojas, os } \\
\text { motoristas do táxi, os meninos no } \\
\text { escritório. }\end{array}$ & $\begin{array}{l}\text { [...] infelizmente eu acho que eu acabei } \\
\text { aprendendo Português coloquial } \\
\text { (cotidiano) com os lojistas, os } \\
\text { motoristas de táxi, os meninos do } \\
\text { escritório. }\end{array}$ \\
\hline $\begin{array}{l}\text { Eu estou nervioso você vai usar por uma } \\
\underline{\text { outra assunto }}\end{array}$ & $\begin{array}{l}\text { Eu estou preocupada porque você vai } \\
\text { usar (está entrevista) para uma outra } \\
\text { finalidade. } \\
\text { (Eu estou achando que vocês vão usar } \\
{[\ldots] \text { ) }}\end{array}$ \\
\hline $\begin{array}{l}\text { E também eu tinha uma professor que } \\
\text { aprendo Inglês na Estados Unidos e [...] } \\
\text { as línguas têm diferências significante. }\end{array}$ & $\begin{array}{l}\text { E, além disso, eu tive uma professora } \\
\text { que aprendeu Inglês nos Estados } \\
\text { Unidos e [...] as línguas têm diferenças } \\
\text { significativas. }\end{array}$ \\
\hline
\end{tabular}




\begin{tabular}{|c|c|}
\hline $\begin{array}{l}{[. . .] \text { mas eu acho que é melhor procurar }} \\
\text { um pessoa que tem as habilidades da } \\
\text { línguas. }\end{array}$ & $\begin{array}{l}\text { [...] mas eu acho que é melhor procurar } \\
\text { uma pessoa (alguém) que tem } \\
\text { competência pedagógica para } \\
\text { línguas (e lingüística = conhecimento } \\
\text { científico da Língua) }\end{array}$ \\
\hline $\begin{array}{l}\text { Mas nem eu não tenho um talento bem } \\
\text { da língua }\end{array}$ & $\begin{array}{l}\text { Mas também eu não tenho um bom } \\
\text { conhecimento (desempenho) da } \\
\text { língua }\end{array}$ \\
\hline $\begin{array}{l}\text { Eu acho que eu perdi um ano, porque eu } \\
\text { não tinha uma sistema. }\end{array}$ & $\begin{array}{l}\text { Eu acho que (eu penso, eu concluo) eu } \\
\text { perdi um ano, porque eu não tinha uma } \\
\text { técnica (na aprendizagem) } \\
\text { (não havia uma técnica adequada de } \\
\text { ensino) }\end{array}$ \\
\hline $\begin{array}{l}\text { Mas, eu }[\ldots] \text { eu tinho, tinha a } \\
\text { responsabilidade por o desenvolvimento } \\
\text { das aulas. }\end{array}$ & $\begin{array}{l}\text { Mas eu é que tinha a responsabilidade } \\
\text { pelo andamento (desenvolvimento) } \\
\text { das aulas. }\end{array}$ \\
\hline $\begin{array}{l}{[\ldots] \text { mas eu tenho uma Quadro, um }} \\
\text { quadro }[\ldots] \text { eles têm uma } \\
\text { "advantage"avantage, porque } \\
\frac{\text { pessoas da escritório fala Inglês bem, }}{\text { fala Português bem. }}\end{array}$ & $\begin{array}{l}\text { [...] mas (felizmente) eu tenho um } \\
\text { quadro (de funcionários) e eles têm } \\
\text { uma vantagem (sobre mim), pois o } \\
\text { pessoal do escritório fala Inglês e } \\
\text { Português bem. }\end{array}$ \\
\hline $\begin{array}{l}{[\ldots] \text { então eu falei Inglês porque eu }} \\
\text { precisei ter uma posição do chefe }\end{array}$ & $\begin{array}{l}\text { [...] eu falava, então, Inglês (então, eu } \\
\text { tinha de falar Inglês) porque eu } \\
\text { precisava assumir uma postura } \\
\text { (comportamento, atitude) de chefe. }\end{array}$ \\
\hline
\end{tabular}

\begin{tabular}{|l|l|}
\hline Eu acho que eu tengo sangre de Irlanda. & $\begin{array}{l}\text { Eu acho que eu tenho sangue da } \\
\text { Irlanda. }\end{array}$ \\
\hline Não sei a palavra para Scotland. & Não sei a palavra para Escócia. \\
\hline $\begin{array}{l}\text { Eu tenho um pouco de [...] britânica de } \\
\text { todas as maneiras. }\end{array}$ & $\begin{array}{l}\text { Eu tenho um pouco de característica } \\
\text { (origem, ascendência) britânica de } \\
\text { todas as maneiras. }\end{array}$ \\
\hline $\begin{array}{l}\text { Sei que Philips (o nome) significa uma } \\
\text { persoa que adora cavalos. }\end{array}$ & $\begin{array}{l}\text { Sei que Philips (o nome) significa uma } \\
\text { pessoa que adora cavalos. }\end{array}$ \\
\hline $\begin{array}{l}\text { Eu estou falando com uma [...] como } \\
\text { uma outra persoa. }\end{array}$ & $\begin{array}{l}\text { Eu estou falando como uma outra } \\
\text { pessoa. }\end{array}$ \\
\hline $\begin{array}{l}\text { Nos EE.UU. não falamos muito sobre a a } \\
\text { origens dos nomes, porque a maioria são }\end{array}$ & $\begin{array}{l}\text { Nos EE.UU. não falamos muito sobre a } \\
\text { origens dos nomes, porque a maioria é }\end{array}$ \\
\hline
\end{tabular}




\begin{tabular}{|c|c|}
\hline um mexilado (mechlado). & uma mistura (mesclado). \\
\hline $\begin{array}{l}\text { [...] completar minha educación sobre } \\
\text { este continente. }\end{array}$ & $\begin{array}{l}{[\ldots] \quad \text { completar meu conhecimento }} \\
\text { (meus estudos) sobre este continente. }\end{array}$ \\
\hline $\begin{array}{l}\text { Eu quero fabiar com Policia da Saúde } \\
\text { Internacional. }\end{array}$ & $\begin{array}{l}\text { Eu quero trabalhar com Política da } \\
\text { Saúde Internacional. }\end{array}$ \\
\hline $\begin{array}{l}\text { Coisas afora de estudar este campo, } \\
\text { este subjecto, eu gosto da literatura }[\ldots]\end{array}$ & $\begin{array}{l}\text { Outras coisas além do estudo relativo a } \\
\text { esta área e a este assunto: eu gosto de } \\
\text { literatura. }\end{array}$ \\
\hline $\begin{array}{l}\text { Mas eu tenho um camino pouco largo } \\
\text { para seguir estes pensamientos. }\end{array}$ & $\begin{array}{l}\text { Mas eu tenho um caminho um pouco } \\
\text { longo para seguir estes pensamentos. }\end{array}$ \\
\hline $\begin{array}{l}\text { Por isso, conversação e relações entre } \\
\text { as pessoas. }\end{array}$ & $\begin{array}{l}\text { Por isso, conversa (bate-papo) e } \\
\text { relações entre as pessoas. }\end{array}$ \\
\hline $\begin{array}{l}\text { Segunda coisa sobre as pessoas aqui } \\
\text { são as conversações. }\end{array}$ & $\begin{array}{l}\text { A segunda coisa sobre as pessoas } \\
\text { daqui são os bate-papos. }\end{array}$ \\
\hline $\begin{array}{l}{[\ldots] \text { sobre o povo brasileiro eu acho que }} \\
{[\ldots] \text { são um povo muito dinâmico }[\ldots] \text { e }} \\
\text { também integrado por ação de espacio. }\end{array}$ & $\begin{array}{l}{[\ldots] \text { sobre o povo brasileiro eu acho que }} \\
{[\ldots] \text { é um povo muito dinâmico }[\ldots] \text { e }} \\
\text { também integrado em conseqüência de } \\
\text { (devido ao) espaço. }\end{array}$ \\
\hline $\begin{array}{l}{[\ldots] \text { o dinâmico das conversações mesmo }} \\
\text { são diferentes. }\end{array}$ & $\begin{array}{l}{[\ldots] \text { o dinamismo dos bate-papos }} \\
\text { mesmo é diferente. }\end{array}$ \\
\hline $\begin{array}{l}\text { e esse tipo de você ficar numa atitude } \\
\text { onde todo mundo ficar uma mesa falando } \\
\text { sobre três coisas ao mesmo tempo. }\end{array}$ & $\begin{array}{l}\text { e esse modo de você ficar (encontrar- } \\
\text { se) numa situação em que todo mundo } \\
\text { fica em uma mesa falando sobre três } \\
\text { coisas ao mesmo tempo. }\end{array}$ \\
\hline $\begin{array}{l}\text { eu acho que existe mais machismo e } \\
\text { mais sexismo aqui no Brasil. }\end{array}$ & $\begin{array}{l}\text { eu acho que existe mais machismo e } \\
\text { mais sexualidade aqui no Brasil. }\end{array}$ \\
\hline $\begin{array}{l}\text { [...] em minha concepção de fimanismo e } \\
\text { igualidade entre os sexos. }\end{array}$ & $\begin{array}{l}{[\ldots] \text { em minha concepção de feminismo }} \\
\text { e igualdade entre os sexos. }\end{array}$ \\
\hline $\begin{array}{l}{[\ldots] \text { uma coisa que me incomoda aqui é a }} \\
\text { concepção do tempo; e não é como tem } \\
\text { uma concepção fixa [...] uma lista de } \\
\text { regras [...] que tempos você deve chegar } \\
\text { na hora. }\end{array}$ & $\begin{array}{l}\text { [...] uma coisa que me incomoda aqui é } \\
\text { o compromisso com o horário; é } \\
\text { como não tivesse (porque não tem) uma } \\
\text { norma fixa } \quad[. .] \text { regras pré- } \\
\text { estabelecidas }[\ldots] \text { em que situações } \\
\text { (momentos, ocasiões) você deve } \\
\text { chegar na hora. }\end{array}$ \\
\hline $\begin{array}{l}{[\ldots] \text { são o povo porque são muito }} \\
\text { interessantes e muito fácil para conecer }\end{array}$ & $\begin{array}{l}\text { [...] é o povo (brasileiro) porque é muito } \\
\text { interessante, muito fácil de conhecer e }\end{array}$ \\
\hline
\end{tabular}




\begin{tabular}{|c|c|}
\hline e formar amistagem. & fazer amizade. \\
\hline $\begin{array}{l}{[\ldots] \text { com mil estudantes e depois High }} \\
\text { School com [...] um classe e um grupo de } \\
\underline{\text { colegas de doiscentos e vinte. }}\end{array}$ & $\begin{array}{l}\text { [...] com mil estudantes e depois High } \\
\text { School com uma turma de duzentos e } \\
\text { vinte (estudantes, alunos). }\end{array}$ \\
\hline $\begin{array}{l}{[\ldots] \text { Austin, a capital de Texas, com um }} \\
\text { milion, populación de um milion }[\ldots]\end{array}$ & $\begin{array}{l}\text { [...] Austin, a capital do Texas, com uma } \\
\text { população de um milhão (de pessoas). }\end{array}$ \\
\hline $\begin{array}{l}{[\ldots] \text { primeiro razón eu queria } \underline{\text { uma }}} \\
\text { descansa não, mas uma coisa deferente, } \\
\text { um ano de enriquecimen [...] algo assim. }\end{array}$ & $\begin{array}{l}\text { [...] a primeira razão não era que eu } \\
\text { queria dar uma descansada (uma } \\
\text { relaxada, um descanso) não, mas uma } \\
\text { coisa diferente, um ano de } \\
\text { enriquecimento [...] algo assim. }\end{array}$ \\
\hline $\begin{array}{l}{[\ldots] \text { eu queria aumentar um pouco mia }} \\
\text { conocimiento das Línguas românticas, ou } \\
\underline{\text { Romanças. }}\end{array}$ & $\begin{array}{l}\text { [...] eu queria aumentar um pouco } \\
\text { (melhorar) meu conhecimento sobre as } \\
\text { Línguas Românicas. }\end{array}$ \\
\hline $\begin{array}{l}\text { [...] além de isso, eu queria estudar } \\
\text { Saúde Pública do Brasil [...] eu vou, } \\
\text { também, conseguir um Maestro na } \\
\text { Saúde Pública. }\end{array}$ & $\begin{array}{l}\text { [...] além disso, eu queria estudar Saúde } \\
\text { Pública do Brasil [...] eu vou, também, } \\
\text { obter um Mestrado em Saúde Pública. }\end{array}$ \\
\hline $\begin{array}{l}{[\ldots] \text { eu estudei muito os países }} \\
\text { hispânicas, mas o Brasil foi um pouco ao } \\
\text { lado porque uma exception, é deferente. }\end{array}$ & $\begin{array}{l}{[\ldots] \text { eu estudei muito os países }} \\
\text { hispânicos, mas o Brasil ficou um pouco } \\
\text { de lado (excluído) porque é uma } \\
\text { exceção, é diferente. }\end{array}$ \\
\hline $\begin{array}{l}\text { [...] uma coisa especificamente de São } \\
\text { Paulo que é a estilo de vida urbana; este } \\
\text { inclui poluição, este inclui transportação, } \\
\text { este inclui falta de naturaleza e, algumas } \\
\text { vezes, falta de alsêdino mesmo. }\end{array}$ & $\begin{array}{l}\text { [...] um coisa especificamente de São } \\
\text { Paulo que é o estilo (modo) de vida } \\
\text { urbano; que inclui poluição, que inclui } \\
\text { transporte (locomoção), que inclui falta } \\
\text { de ambiente natural e, algumas vezes, } \\
\text { falta de asseio (higiene) mesmo. }\end{array}$ \\
\hline $\begin{array}{l}{[\ldots] \text { Brasil tem su }[\ldots] \text { seus problemas }} \\
\text { neste }[. . .] \text { este campo. }\end{array}$ & $\begin{array}{l}{[\ldots] \text { Brasil tem seus problemas nessa }} \\
\text { área. }\end{array}$ \\
\hline $\begin{array}{l}\text { Você tem que passar uma hora para } \\
\text { chegar dois quilômetros por ação do } \\
\text { trânsito. }\end{array}$ & $\begin{array}{l}\text { Você tem que gastar (levar) uma hora } \\
\text { para percorrer dois quilômetros devido } \\
\text { ao (pelo congestionamento do) } \\
\text { trânsito. }\end{array}$ \\
\hline É difícil de ser muito saudável. & É difícil ter boa saúde. \\
\hline $\begin{array}{l}\text { Você não pode passear uma parque, } \\
\text { porque só parque que fica na Birapuera é } \\
\text { uma hora e meia da minha casa. }\end{array}$ & $\begin{array}{l}\text { Você não pode passear num parque, } \\
\text { porque só o parque do Ibirapuera fica a } \\
\text { uma hora e meia da minha casa. }\end{array}$ \\
\hline Eu só tenho uma sala de exercícios para & sala de ginástica para \\
\hline
\end{tabular}




\begin{tabular}{|c|c|}
\hline tentar manter minha saúde. & tentar manter minha forma física. \\
\hline Minha programa dura até o dezembro. & $\begin{array}{l}\text { Meu curso vai até (termina em) } \\
\text { dezembro. }\end{array}$ \\
\hline $\begin{array}{l}{[\ldots] \text { tem coisas }[\ldots] \text { tem tarefas aqui (no }} \\
\text { Brasil) que precisam ser feitos. }\end{array}$ & $\begin{array}{l}{[\ldots] \text { tem coisas }[\ldots] \text { tem serviços }} \\
\text { (trabalhos) aqui (no Brasil) que } \\
\text { precisam ser feitos (executados). }\end{array}$ \\
\hline $\begin{array}{l}{[\ldots] \text { e eu quero estudar para chegar a um }} \\
\text { nível de entendimento que eu preciso } \\
\text { para ajudar ... }\end{array}$ & $\begin{array}{l}{[\ldots] \text { e eu quero estudar para chegar a }} \\
\text { um nível de conhecimento } \\
\text { (compreensão) que eu preciso para } \\
\text { ajudar (as pessoas) [...] }\end{array}$ \\
\hline É uma cultura muito engraçado. & É um povo muito engraçado. \\
\hline $\begin{array}{l}\text { Eles (o povo brasileiro) ajuda Quando } \\
\text { uma persoa perdido como eu a maioria } \\
\text { dos tempos precisa [...] precisa ajuda. }\end{array}$ & $\begin{array}{l}\text { Eles (os brasileiros) ajudam quando } \\
\text { uma pessoa se encontra perdida como } \\
\text { eu, na maior parte do tempo (na } \\
\text { maioria das vezes), e precisa de ajuda. }\end{array}$ \\
\hline $\begin{array}{l}{[\ldots] \text { é um país tão diverso Quanto }} \\
\text { interessante e fica culturalmente. }\end{array}$ & $\begin{array}{l}{[\ldots] \text { é um país tão diverso quanto }} \\
\text { interessante e fica importante } \\
\text { culturalmente. } \\
{[\ldots] \text { é um país tão diverso quanto }} \\
\text { interessante e fica importante para a } \\
\text { cultura. } \\
{[\ldots] \text { é um país tão diverso quanto }} \\
\text { interessante e ganha importância } \\
\text { cultural. }\end{array}$ \\
\hline $\begin{array}{l}\text { [...] já assisti uma teatro de um grupo de } \\
\text { percussión da Índia. }\end{array}$ & $\begin{array}{l}{[\ldots] \text { já assisti a uma apresentação de um }} \\
\text { grupo de percussão da Îndia. }\end{array}$ \\
\hline $\begin{array}{l}\text { Outro desventagem é a dificuldade de } \\
\text { transportar-me em São Paulo. }\end{array}$ & $\begin{array}{l}\text { Outra desvantagem é a dificuldade de } \\
\text { locomoção em São Paulo. }\end{array}$ \\
\hline $\begin{array}{l}{[\ldots] \text { e a poluição e as coisas que são }} \\
\text { verdade para toda centros urbanos. }\end{array}$ & $\begin{array}{l}\text { [...] a poluição e as coisas que são } \\
\text { realidade (verdadeiras, comuns, } \\
\text { normais, estão presentes) em todos os } \\
\text { centros urbanos. }\end{array}$ \\
\hline $\begin{array}{l}\text { Outra vantagem é a flexibilidade porque } \\
\text { têm menos regras sobre coisas como } \\
\text { tempo. }\end{array}$ & $\begin{array}{l}\text { Outra vantagem é a facilidade para as } \\
\text { coisas (liberdade) porque têm (existem) } \\
\text { menos controle (normas) para as } \\
\text { coisas como o horário. }\end{array}$ \\
\hline $\begin{array}{l}{[\ldots] \text { as regras culturais são pouco mais }} \\
\text { flexíveis. }\end{array}$ & $\begin{array}{l}{[\ldots] \text { as normas (padrões) culturais são }} \\
\text { um pouco mais flexíveis. }\end{array}$ \\
\hline
\end{tabular}




\begin{tabular}{|c|c|}
\hline $\begin{array}{l}{[\ldots] \text { eu posso ter acesso ao cadáveres }} \\
{[\ldots] \text { e nos Estados Unidos porque temos }} \\
\text { muitos advogados que têm que ser, tem } \\
\text { que ser fazendo algo. }\end{array}$ & $\begin{array}{l}\text { [...] (no Brasil) eu posso ter acesso aos } \\
\text { cadáveres [...] mas nos Estados Unidos } \\
\text { não porque temos muita fiscalização } \\
\text { (normas, exigências, controle) que } \\
\text { precisa existir (que é necessária) } \\
\text { quando se está fazendo algo. }\end{array}$ \\
\hline $\begin{array}{l}{[\ldots] \text { alguns estão estudando, alguns }} \\
\text { como eu são no mundo fazendo alguma } \\
\text { coisa. }\end{array}$ & $\begin{array}{l}{[\ldots] \text { alguns (amigos) estão } \text { ainda }} \\
\text { estudando (na Faculdade), outros } \\
\text { (estudantes) como eu estão pelo } \\
\text { mundo fazendo alguma coisa. }\end{array}$ \\
\hline $\begin{array}{l}{[\ldots] \text { e eu sinto falta de estas persoas }} \\
\text { importantes. }\end{array}$ & $\begin{array}{l}{[\ldots] \text { e eu sinto falta dessas pessoas }} \\
\text { importantes. }\end{array}$ \\
\hline $\begin{array}{l}\text { Sinto falta da [...] para ser fluente quando } \\
\text { estou expressando mios pensamientos. }\end{array}$ & $\begin{array}{l}\text { Sinto falta de fluência, de ser fluente } \\
\text { quando estou expressando meus } \\
\text { pensamentos. }\end{array}$ \\
\hline $\begin{array}{l}{[\ldots] \text { sinto falta da }[\ldots] \text { do meu carro, }} \\
\text { transportación; a palavra es auto-pista } \\
\text { em espanhol, highway (em Inglês), né? }\end{array}$ & $\begin{array}{l}{[\ldots] \text { sinto falta do meu carro, de vias }} \\
\text { principais; a palavra é auto-pista em } \\
\text { espanhol }[\ldots]\end{array}$ \\
\hline $\begin{array}{l}{[\ldots] \text { mas os caminos, os "roads" mesmo }} \\
\text { são [...] são um pouco melior por ação de } \\
\text { menos trânsito. }\end{array}$ & $\begin{array}{l}{[\ldots] \text { mas os caminhos, as estradas }} \\
\text { mesmo são um pouco melhores devido } \\
\text { a (por causa de) menos trânsito. }\end{array}$ \\
\hline $\begin{array}{l}\text { Eu sento falta de um camino para correr, } \\
\text { para fazer exercícios } \frac{}{[\ldots]}\end{array}$ & $\begin{array}{l}\text { Eu sinto falta de uma pista de corrida, } \\
\text { (um lugar) para fazer exercícios [...] }\end{array}$ \\
\hline $\begin{array}{l}\text { Uma diferência muito grande aqui é o } \\
\text { comida, especificamente, o conceito de } \\
\text { "por kilo" é muito bom [...] }\end{array}$ & $\begin{array}{l}\text { Uma diferença muito grande aqui é a } \\
\text { comida, especificamente, } \\
\text { caracterização (a idéia, o tipo) de "por } \\
\text { kilo" é muito bom [...] }\end{array}$ \\
\hline $\begin{array}{l}{[\ldots] \text { tem todos os grupos de comida, de }} \\
\text { legumes, etc. }\end{array}$ & $\begin{array}{l}{[\ldots] \text { tem todos os tipos (espécies) de }} \\
\text { comida, de legumes, etc. }\end{array}$ \\
\hline $\begin{array}{l}\text { Nos Estados Unidos [...] é difícil achar } \\
\text { uma coisa que dá bom para o corpo. }\end{array}$ & $\begin{array}{l}\text { Nos Estados Unidos [...] é difícil achar } \\
\text { uma coisa que faz bem ao corpo. }\end{array}$ \\
\hline $\begin{array}{l}\text { Semelhança entre }[. . .] \text { eu vou falar um } \\
\text { pouco sobre os sociedades, entre os dois } \\
\text { países. }\end{array}$ & $\begin{array}{l}{[\ldots] \text { eu vou falar um pouco sobre os }} \\
\text { ovos, (para mostrar) a semelhança } \\
\text { entre os dois países. }\end{array}$ \\
\hline [...] tem uma diferência na Língua. & [...] tem uma diferença na Língua. \\
\hline $\begin{array}{l}{[\ldots] \text { eles têm uma desejo de aprender e }} \\
\text { entender e lutar para coisas. }\end{array}$ & $\begin{array}{l}{[\ldots] \text { eles (os estudantes) têm vontade }} \\
\text { de aprender, entender e lutar pelas } \\
\text { coisas. }\end{array}$ \\
\hline
\end{tabular}




\begin{tabular}{|c|c|}
\hline $\begin{array}{l}{[\ldots] \text { e este tipo de energia que talvez é }} \\
\text { uma diferência também. }\end{array}$ & $\begin{array}{l}{[\ldots] \text { e este tipo de interesse }} \\
\text { (disposição, garra) que talvez seja uma } \\
\text { diferença também. }\end{array}$ \\
\hline $\begin{array}{l}\text { [...] este dimanismo é talvez um pouco } \\
\text { maior aqui que nos Estados Unidos. }\end{array}$ & $\begin{array}{l}{[\ldots] \text { este dinamismo é talvez um pouco }} \\
\text { maior aqui que nos Estados Unidos. }\end{array}$ \\
\hline $\begin{array}{l}\text { [...] su país mesmo es uma época muito } \\
\text { importante e muito [...] é um sentido novo } \\
\text { economicamente. }\end{array}$ & $\begin{array}{l}\text { [...] seu país mesmo vive um período } \\
\text { (uma fase) muito importante é uma } \\
\text { visão nova economicamente. }\end{array}$ \\
\hline $\begin{array}{l}{[\ldots] \text { eles sentem uma responsabilidade }} \\
\text { de ser envolvidos em este processo de } \\
\text { melhorar o Brasil. }\end{array}$ & $\begin{array}{l}{[\ldots] \text { eles sentem uma necessidade de }} \\
\text { ficar envolvidos neste processo de } \\
\text { evolução do Brasil. }\end{array}$ \\
\hline $\begin{array}{l}\text { Este, esse atitude não existe tanto nos } \\
\text { Estados Unidos. }\end{array}$ & $\begin{array}{l}\text { Esta postura } \text { (tendência, } \\
\text { característica) não é comum } \\
\text { (freqüente) nos Estados Unidos. } \\
\text { Esta postura não se encontra com } \\
\text { facilidade nos Estados Unidos. }\end{array}$ \\
\hline $\begin{array}{l}\text { Eu passo a maioria de meu tempo aqui } \\
\text { em a USP. }\end{array}$ & $\begin{array}{l}\text { Eu passo a maior parte do meu tempo } \\
\text { aqui na USP. }\end{array}$ \\
\hline $\begin{array}{l}\text { Eu acho que o brasileiro dão mais [...] } \\
\text { valoriza mais as relações entre as } \\
\text { persoas. }\end{array}$ & $\begin{array}{l}\text { Eu acho que o brasileiro dá mais valor, } \\
\text { valoriza mais as relações entre as } \\
\text { pessoas. }\end{array}$ \\
\hline $\begin{array}{l}{[\ldots] \text { eu acho que toda a vida, talvez, }} \\
\text { relata o tem que ser com um aspecto da } \\
\text { família. }\end{array}$ & $\begin{array}{l}{[\ldots] \text { eu acho que todas as vezes, }} \\
\text { talvez, quando desenvolve um tema } \\
\text { (fala sobre um assunto), tem de ser com } \\
\text { um aspecto da família. }\end{array}$ \\
\hline $\begin{array}{l}{[\ldots] \text { e as }[\ldots] \text { o únito familiar eu acho }} \\
\text { fundamental para a cultura brasileira. }\end{array}$ & $\begin{array}{l}{[\ldots] \text { e eu acho fundamental a união }} \\
\text { familiar para a cultura brasileira. }\end{array}$ \\
\hline $\begin{array}{l}{[\ldots] \text { e eu acho que a cultura americana }} \\
\text { nunca vai fazer. }\end{array}$ & $\begin{array}{l}{[\ldots] \text { e eu acho que o povo americano }} \\
\text { numa vai fazer. } \\
{[\ldots] \text { e eu acho que a sociedade }} \\
\text { americana nunca vai adotar. }\end{array}$ \\
\hline $\begin{array}{l}\text { Uma outro hábito perigloso que eu veo } \\
\text { nas ruas são as [...] a métoda de dirigir } \\
\text { aqui, especialmente os motorciclistas. }\end{array}$ & $\begin{array}{l}\text { Um outro hábito perigoso que eu vejo } \\
\text { nas ruas é o modo (a maneira) de } \\
\text { dirigir aqui, especialmente os } \\
\text { motociclistas. }\end{array}$ \\
\hline $\begin{array}{l}{[\ldots] \text { têm muitos accidentes que podem }} \\
\text { ser evitados com um [...] un [...] algum } \\
\text { tipo de, algumas regras de tráfico um }\end{array}$ & $\begin{array}{l}{[\ldots] \text { têm muitos acidentes que podem }} \\
\text { ser evitados com algum tipo de norma, } \\
\text { algumas normas de trânsito um pouco }\end{array}$ \\
\hline
\end{tabular}




\begin{tabular}{|c|c|}
\hline pouco mais rígidos. & mais rígidas. \\
\hline $\begin{array}{l}{[\ldots] \text { e talvez um pouco so }[\ldots] \text { algumas }} \\
\text { policias bem reforçado a essas regras. }\end{array}$ & $\begin{array}{l}{[\ldots] \text { e talvez um pouco mais de controle }} \\
\text { policial (comando policial, policiamento) } \\
\text { bem reforçado (atento) para obediência } \\
\text { (respeito, cumprimento) a essas } \\
\text { normas. } \\
{[\ldots] \text { e talvez um pouco mais (um número }} \\
\text { maior) de policiais bem reforçados } \\
\text { (atentos) a essas normas. } \\
\text { [...] e talvez alguns policiais bem } \\
\text { reforçados (atentos) a essas normas. } \\
{[\ldots] \text { e talvez uma polícia bem reforçada }} \\
\text { (atenta) a essas normas. }\end{array}$ \\
\hline $\begin{array}{l}{[\ldots] \text { é verdademente uma, vou dizer, }} \\
\text { entropia nas ruas. }\end{array}$ & $\begin{array}{l}{[\ldots] \text { é na verdade um, vou dizer, }} \\
\text { congestionamento (entupimento) nas } \\
\text { ruas. }\end{array}$ \\
\hline $\begin{array}{l}{[\ldots] \text { e este }[\ldots] \text { funciona um nivél e }} \\
\text { também outro nivél é muito perigloso. }\end{array}$ & $\begin{array}{l}{[\ldots] \text { e este funciona por um lado, por }} \\
\text { outro lado é muito perigoso. }\end{array}$ \\
\hline $\begin{array}{l}\text { eu estava lendo hoje mesmo sobre seu } \\
\text { policia equenômica }\end{array}$ & $\begin{array}{l}\text { eu estava lendo hoje mesmo sobre sua } \\
\text { política econômica. }\end{array}$ \\
\hline $\begin{array}{l}{[\ldots] \text { seu policia equenômica tinha }} \\
\text { ajudado muito para a estabilização da } \\
\text { currencia brasileira. }\end{array}$ & $\begin{array}{l}{[\ldots] \text { sua política econômica tinha }} \\
\text { ajudado muito a estabilização da moeda } \\
\text { brasileira. }\end{array}$ \\
\hline $\begin{array}{l}{[\ldots] \text { ele é a autoridade de este país e }} \\
\text { neste questión }[\ldots] \text { questón }[\ldots]\end{array}$ & $\begin{array}{l}{[\ldots] \text { ele é a autoridade deste país e }} \\
\text { nesta questão }[\ldots]\end{array}$ \\
\hline $\begin{array}{l}{[\ldots] \text { e neste problema sério sobre a }} \\
\text { economia e a corrente, a moeda, } \underline{\text { moeda }} \\
\text { de }[. . .] \text { do Brasil }[\ldots]\end{array}$ & $\begin{array}{l}{[\ldots] \text { e nesse problema sério sobre a }} \\
\text { economia e a moeda corrente do } \\
\text { Brasil }[\ldots]\end{array}$ \\
\hline $\begin{array}{l}\text { Nos Estados Unidos é um dific }[. . .] \text { é um } \\
\text { pouco difícil }[\ldots]\end{array}$ & $\begin{array}{l}\text { Nos Estados Unidos é uma dificuldade; } \\
\text { é um pouco difícil }[\ldots]\end{array}$ \\
\hline $\begin{array}{l}\text { [...] porque estava passando um econ-je; } \\
\text { nossas [...] nossa figura, nossa chefe, } \\
\text { nossa presidente mesmo etá tendo } \\
\text { algumas problemas. }\end{array}$ & $\begin{array}{l}{[\ldots] \text { porque estava passando um }} \\
\text { noticiário (uma reportagem, um } \\
\text { programa econômico) "economia } \\
\text { mundial hoje"; nosso representante, } \\
\text { nosso chefe, nosso presidente mesmo } \\
\text { está tendo alguns problemas. }\end{array}$ \\
\hline $\begin{array}{l}{[\ldots] \text { algumas coisas que eu admiro sobre }} \\
\text { ele, sua estilo de falar e }[\ldots]\end{array}$ & $\begin{array}{l}{[\ldots] \text { algumas coisas que eu admiro nele, }} \\
\text { seu modo de se expressar }\end{array}$ \\
\hline
\end{tabular}




\begin{tabular}{|c|c|}
\hline & (comunicar) e $[\ldots]$ \\
\hline $\begin{array}{l}{[\ldots] \text { vou deixar este }[\ldots] \text { este parte da }} \\
\text { pergunta ao lado. }\end{array}$ & $\begin{array}{l}{[\ldots] \text { vou deixar esta parte da pergunta }} \\
\text { de lado. }\end{array}$ \\
\hline $\begin{array}{l}\text { O grande desejo }[\ldots] \text { é o desejo de } \\
\text { melhorar e ser um dos líderes dos país } \\
\text { que }[\ldots]\end{array}$ & $\begin{array}{l}\text { O grande desejo [...] é o desejo de } \\
\text { melhorar e ser um dos países líderes, } \\
\text { que }[\ldots . .\end{array}$ \\
\hline $\begin{array}{l}{[\ldots] \text { que }[\ldots] \text { no sê a palavra }[\ldots] \text { que }} \\
\text { Brasil pára na cabeça; este é o desejo } \\
\text { mesmo para entrar na }[\ldots] \text { no primeiro } \\
\text { mundo, [...] }\end{array}$ & $\begin{array}{l}{[\ldots] \text { que }[\ldots] \text { não sei a expressão [...] }} \\
\text { que o Brasil fica na mente (dos } \\
\text { brasileiros); esse é o desejo mesmo de } \\
\text { entrar para o primeiro mundo, }[. . .]\end{array}$ \\
\hline $\begin{array}{l}\text { Necessidade são óbvios: falta dinheiro, } \\
\text { têm favelos, tem meninos da rua }[\ldots]\end{array}$ & $\begin{array}{l}\text { As necessidades são óbvias: falta } \\
\text { dinheiro, têm favelas, têm meninos de } \\
\text { rua [...] }\end{array}$ \\
\hline $\begin{array}{l}{[\ldots] \text { tem uma expectativa da vida muito }} \\
\text { curto. }\end{array}$ & $\begin{array}{l}{[\ldots] \text { tem uma expectativa de vida muito }} \\
\text { curta. }\end{array}$ \\
\hline $\begin{array}{l}{[\ldots] \quad \text { (têm) problemas com literacia, }} \\
\text { educación, temo uma falta de confiança } \\
\text { nos políticos. }\end{array}$ & $\begin{array}{l}{[\ldots] \text { (têm) problemas com alfabetismo, }} \\
\text { estudos (formação), temos um } \\
\text { descrédito (uma desconfiança) nos } \\
\text { políticos. }\end{array}$ \\
\hline $\begin{array}{l}{[\ldots] \text { é um obstáculo mesmo de formar }} \\
\text { que }[\ldots]\end{array}$ & $\begin{array}{l}{[\ldots] \text { é um problema (uma dificuldade) }} \\
\text { mesmo de entender que }[\ldots]\end{array}$ \\
\hline $\begin{array}{l}{[\ldots] \text { a coisa que Brasil precisa mais e é }} \\
\text { uma identidade nacional. }\end{array}$ & $\begin{array}{l}{[\ldots] \text { a coisa de que o Brasil mais precisa }} \\
\text { é uma independência política } \\
\text { (nacional). }\end{array}$ \\
\hline $\begin{array}{l}{[\ldots] \text { eu estou falando completamente de }} \\
{[\ldots] \text { do ponto de visto americano }[\ldots]}\end{array}$ & $\begin{array}{l}{[\ldots] \text { eu estou falando especificamente }} \\
\text { do ponto de vista americano }[\ldots]\end{array}$ \\
\hline $\begin{array}{l}\text { Eu gostaria dizer a }[\ldots] \text { o, esta é uma } \\
\text { seleción, mas mais uma "compliment" } \\
\text { aos brasileiros }[\ldots]\end{array}$ & 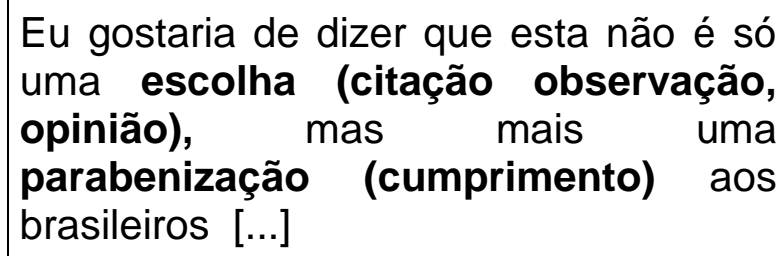 \\
\hline $\begin{array}{l}{[\ldots] \text { e este força, este vantagem que }} \\
\text { Brasil tem pode ser usado para melhorar } \\
{[\ldots]}\end{array}$ & $\begin{array}{l}\text { - (referindo-se ao dinamismo dos } \\
\text { brasileiros) [...] e esta força de } \\
\text { vontade, esta vantagem que o Brasil } \\
\text { tem pode ser usada para melhorar }[\ldots]\end{array}$ \\
\hline $\begin{array}{l}{[\ldots] \text { este é uma, é um fenômeno }} \\
\text { humano, não? }\end{array}$ & $\begin{array}{l}\text { - (comeu alguma coisa e fez mal) }[\ldots] \\
\text { esse é um acontecimento natural do } \\
\text { (comum no) homem, não? }\end{array}$ \\
\hline
\end{tabular}




\begin{tabular}{|c|c|}
\hline $\begin{array}{l}{[\ldots] \text { quando eu sento triste, eu sento }} \\
\text { saudade muito forte para meu país }[\ldots]\end{array}$ & $\begin{array}{l}{[\ldots] \text { quando eu sinto tristeza, eu sinto }} \\
\text { uma saudade muito forte de meu país } \\
{[\ldots]}\end{array}$ \\
\hline $\begin{array}{l}{[\ldots] \text { você tem que dar tempo para }} \\
\text { ajuscar }[. . .] \text { ajuscar à cultura. }\end{array}$ & $\begin{array}{l}\text { [...] você tem de dar tempo para se } \\
\text { adaptar (ajustar) aos hábitos (aos } \\
\text { costumes) do país. }\end{array}$ \\
\hline $\begin{array}{l}\text { este, este eu falo com certeza que coisas } \\
\text { são mais e mais fáceis. }\end{array}$ & $\begin{array}{l}\text { Isto eu falo com segurança que as } \\
\text { coisas ficam mais e mais (cada vez } \\
\text { mais) fáceis. }\end{array}$ \\
\hline $\begin{array}{l}{[\ldots] \text { é difícil este tip }[\ldots] \text { este periodo de }} \\
\text { ajustar. }\end{array}$ & $\begin{array}{l}{[\ldots] \text { é difícil este período (fase) de }} \\
\text { adaptação. }\end{array}$ \\
\hline $\begin{array}{l}{[\ldots] \text { e estou saindo agora e eu sei que a }} \\
\text { meu }[. . .] \text { meliora, sabe? }\end{array}$ & $\begin{array}{l}{[\ldots] \text { e estou saindo agora (dessa }} \\
\text { depressão) e eu sei que o meu estado } \\
\text { de espírito (humor) vai melhorar, } \\
\text { sabe? }\end{array}$ \\
\hline $\begin{array}{l}\text { Eu acho que falta primeira sobre a Inglês } \\
\text { aqui no Brasil }[\ldots]\end{array}$ & $\begin{array}{l}\text { Eu acho que o que mais falta nos } \\
\text { cursos de Inglês aqui no Brasil }[. . .]\end{array}$ \\
\hline $\begin{array}{l}{[\ldots] \text { eu acho que a Inglês aqui deve focar }} \\
\text { mais na conversación e a pronunciación. }\end{array}$ & $\begin{array}{l}{[\ldots] \text { eu acho que os cursos de Inglês }} \\
\text { aqui devem enfocar mais a } \\
\text { conversação e a pronúncia. }\end{array}$ \\
\hline $\begin{array}{l}{[\ldots] \text { porque talvez com sua exposto à }} \\
\text { televisión e Inglês falado, os estudantes, } \\
\text { eles conseguem entender os ordens das } \\
\text { palavras. }\end{array}$ & $\begin{array}{l}\text { [...] porque talvez com sua exposição à } \\
\text { televisão e Inglês falado (ouvindo } \\
\text { Inglês), os estudantes conseguem } \\
\text { entender a seqüência (a ordem) das } \\
\text { palavras. }\end{array}$ \\
\hline $\begin{array}{l}\text { eu acho que eles podem conseguir } \\
\text { escrever ou, pelo menos, construir uma } \\
\text { com-frase ("confrase"), mas eles não } \\
\text { podem enunciar, falar esse frase. }\end{array}$ & $\begin{array}{l}\text { eu acho que eles conseguem aprender } \\
\text { (assimilar) a escrita ou, pelo menos, } \\
\text { construir (criar) uma frase (um período, } \\
\text { um texto), mas eles não podem } \\
\text { enunciar, falar essa frase (esse } \\
\text { período, esse texto). }\end{array}$ \\
\hline $\begin{array}{l}{[\ldots] \text { as regras podem seguir em sua vez }} \\
\text { quando, quando são, Quando surgem no } \\
{[\ldots] \text { na conversaçación. }}\end{array}$ & $\begin{array}{l}\text { [...] as regras podem ser ensinadas por } \\
\text { vez (uma a uma, uma de cada vez) } \\
\text { quando (à medida que) aparecem no } \\
\text { diálogo (na conversação). }\end{array}$ \\
\hline $\begin{array}{l}\text { Este pode ser } 0[\ldots] \text { aos estrutura, pode } \\
\text { ser um estrutura tópica mesmo, de }[\ldots] \\
\text { topical. }\end{array}$ & $\begin{array}{l}\text { Este pode ser um tópico relativo à } \\
\text { estrutura da Língua, pode ser um } \\
\text { tópico estrutural mesmo. }\end{array}$ \\
\hline [...], besseado em essas conversações e & (tópico estrutural) baseado nessas \\
\hline
\end{tabular}




\begin{tabular}{|c|c|}
\hline $\begin{array}{l}\text { a fundo de essa presenta as regras e as } \\
\text { coisas gramáticas. }\end{array}$ & $\begin{array}{l}\text { conversações e, paralelamente (às } \\
\text { vezes) a elas, apresenta as regras e os } \\
\text { itens (os tópicos) gramaticais. }\end{array}$ \\
\hline $\begin{array}{l}{[\ldots] \text { usualmente representantes da cultura }} \\
\text { brasileira é a professora. }\end{array}$ & $\begin{array}{l}{[\ldots] \text { usualmente os conhecedores da }} \\
\text { cultura brasileira são os professores. } \\
{[\ldots] \text { usualmente a conhecedora da }} \\
\text { cultura brasileira é a professora. }\end{array}$ \\
\hline $\begin{array}{l}{[\ldots] \text { e também expressar seus }[. . .] \text { seus, }} \\
\text { seu ponto de vista. }\end{array}$ & $\begin{array}{l}{[\ldots] \text { e também expressar seus }} \\
\text { pensamentos, seu ponto de vista. }\end{array}$ \\
\hline $\begin{array}{l}\text { [...] este décico livre do poder pode ser } \\
\text { um problema. }\end{array}$ & $\begin{array}{l}{[\ldots] \text { este gesto (atitude) livre do poder }} \\
\text { pode ser um problema. }\end{array}$ \\
\hline $\begin{array}{l}\text { os professores precisam saber que os } \\
\text { estudantes têm sus limitações de [...] } \frac{\text { de }}{\text { [...] culturais. }}\end{array}$ & $\begin{array}{l}\text { os professores precisam saber que os } \\
\text { alunos têm suas limitações de língua, } \\
\text { de referências (abordagens) culturais. }\end{array}$ \\
\hline $\begin{array}{l}{[\ldots] \text { e este }[\ldots] \text { uma obstáculo, }} \\
\text { desvantagem de este tipo de curso } \\
\underline{\text { um }}\end{array}$ & $\begin{array}{l}{[\ldots] \text { e isto se torna um problema, uma }} \\
\text { desvantagem neste (deste) método de } \\
\text { ensino }[. . .]\end{array}$ \\
\hline $\begin{array}{l}{[\ldots] \text { quando a professora usa sua }} \\
\text { ventagem de língua para negar as coisas } \\
\text { culturais. }\end{array}$ & $\begin{array}{l}{[\ldots] \text { quando a professora usa seu }} \\
\text { domínio de } \begin{array}{l}\text { língua } \\
\text { conhecimento) para contestar as } \\
\text { coisas culturais. }\end{array}\end{array}$ \\
\hline $\begin{array}{l}\text { [...] e fica mais e mais claro depois de } \\
\text { uma só presentación. }\end{array}$ & $\begin{array}{l}{[. . .] \text { e fica cada vez mais claro depois de }} \\
\text { uma só apresentação. }\end{array}$ \\
\hline $\begin{array}{l}{[\ldots] \text { cada aula deve ser, deve ter dez }} \\
\text { palavras de vocabulário para aumentar } \\
\text { ao vocabulário dos estudante. }\end{array}$ & $\begin{array}{l}{[\ldots] \text { cada aula deve ter dez palavras }} \\
\text { para aumentar o vocabulário dos } \\
\text { estudantes. }\end{array}$ \\
\hline $\begin{array}{l}{[\ldots] \text { e deve usar, deve ser um }} \\
\text { aprendimento visual. }\end{array}$ & $\begin{array}{l}{[\ldots] \text { e deve usar (adotar) uma }} \\
\text { aprendizagem visual. }\end{array}$ \\
\hline $\begin{array}{l}{[\ldots] \text { a maioria vão ser verbos ou }} \\
\text { substantivos; pode usar um fotogra [...], } \\
\text { foto, foto, um foto ou uma pintura, uma } \\
\text { description visual de uma acción. }\end{array}$ & $\begin{array}{l}\text { [...] a maioria vai (vão) ser verbo(s) ou } \\
\text { substantivo(s); pode usar uma } \\
\text { fotografia, uma foto, ou uma pintura, } \\
\text { uma descrição (uma representação) } \\
\text { visual de uma ação (a gravura de uma } \\
\text { ação). }\end{array}$ \\
\hline $\begin{array}{l}{[\ldots] \text { eu acho que temos muito convers }} \\
{[\ldots] \text {, temos conversación. }}\end{array}$ & $\begin{array}{l}{[\ldots] \text { eu acho que temos muita }} \\
\text { conversação. }\end{array}$ \\
\hline $\begin{array}{l}{[\ldots] \text { usamos a aula para conversar, falar }} \\
\text { sobre canciões. }\end{array}$ & $\begin{array}{l}{[\ldots] \text { usamos a aula para conversar, falar }} \\
\text { sobre canções. }\end{array}$ \\
\hline
\end{tabular}




\begin{tabular}{|c|c|}
\hline $\begin{array}{l}{[\ldots] \text { mas eu acho uma coisa bem legal }} \\
\text { para ajudar com escrever que talvez falta } \\
\text { um pouco, é dar a liberdade para } \\
\text { estudante escrever }[\ldots]\end{array}$ & $\begin{array}{l}{[\ldots] \text { mas eu acho que uma coisa bem }} \\
\text { legal, para ajudar (n)a escrita, e que } \\
\text { talvez falte um pouco, é dar a liberdade } \\
\text { para o estudante escrever }[. . .]\end{array}$ \\
\hline $\begin{array}{l}{[\ldots] \text { talvez uma questión aberto sobre a }} \\
\text { cultura. }\end{array}$ & $\begin{array}{l}{[\ldots] \text { talvez uma questão aberta sobre a }} \\
\text { cultura. }\end{array}$ \\
\hline $\begin{array}{l}{[\ldots] \text { uma coisa sobre a }[\ldots] \text { intercâmbio }} \\
\text { mesmo, este cult }[\ldots] \text { coisas, } \underline{\text { compliques }} \\
\text { culturais. }\end{array}$ & $\begin{array}{l}{[\ldots] \text { uma coisa sobre o intercâmbio }} \\
\text { mesmo, coisas culturais, essas } \\
\text { implicações (questões, confusões, } \\
\text { complicações) culturais. }\end{array}$ \\
\hline $\begin{array}{l}\text { Narrativos para tarefa que pode ajudar } \\
\text { com a língua, com escrito da estudante. }\end{array}$ & $\begin{array}{l}\text { Redações para tarefa que podem } \\
\text { ajudar na aprendizagem da língua, na } \\
\text { escrita do estudante. }\end{array}$ \\
\hline $\begin{array}{l}{[\ldots] \text { também para processo de }} \\
\text { ajustamento, mesmo tempo. }\end{array}$ & $\begin{array}{l}{[\ldots] \text { também no processo de }} \\
\text { adaptação, ao mesmo tempo. }\end{array}$ \\
\hline $\begin{array}{l}{[\ldots] \text { é fundamental que os estudantes }} \\
\text { que têm uma fundación, uma [...] em } \\
\text { uma outra língua, usa esta fundación } \\
\text { para construir o Português. }\end{array}$ & $\begin{array}{l}{[\ldots] \text { é fundamental que os estudantes }} \\
\text { que têm uma base, uma experiência } \\
\text { (um conhecimento) em uma outra } \\
\text { língua, usem esta base para aprender } \\
\text { (dominar) o Português. }\end{array}$ \\
\hline [...] para aprender a Português. & $\begin{array}{l}{[\ldots] \text { para aprender Português (a língua }} \\
\text { portuguesa, o idioma português). }\end{array}$ \\
\hline $\begin{array}{l}{[\ldots] \text { vincular a estrutura Inglês com a }} \\
\text { estrutura Português, com a fundación de } \\
\text { algumas regras. }\end{array}$ & $\begin{array}{l}{[\ldots] \text { comparar a estrutura do Inglês }} \\
\text { (inglesa) com a estrutura do } \\
\text { Português (portuguesa), com o } \\
\text { (através do) estabelecimento de } \\
\text { algumas regras. }\end{array}$ \\
\hline $\begin{array}{l}\text { [...] e talvez vocês notaram que eu falo } \\
\text { talvez demais, demais rápido } \\
\text { considerando minha habilidade de } \\
\text { pronúncia. }\end{array}$ & $\begin{array}{l}{[\ldots] \text { e talvez vocês notaram que eu falo }} \\
\text { rápido demais considerando minha } \\
\text { dificuldade (falta de habilidade, pouca } \\
\text { habilidade) de pronúncia. }\end{array}$ \\
\hline $\begin{array}{l}{[\ldots] \text { eu queria estudar todo tempo }} \\
\text { vocabulário, estructurais verbais }[. . .]\end{array}$ & $\begin{array}{l}{[\ldots] \text { eu queria estudar o tempo todo: }} \\
\text { vocabulário, estruturas verbais }[. . .]\end{array}$ \\
\hline $\begin{array}{l}{[\ldots] \text { uma língua é uma }[\ldots] \text { um grupo de }} \\
\text { regras. }\end{array}$ & $\begin{array}{l}{[\ldots] \text { uma língua é um conjunto de }} \\
\text { regras. }\end{array}$ \\
\hline $\begin{array}{l}\text { Não temos, não temos }[\ldots] \text { nossos } \\
\text { sujeitos não têm sexo. }\end{array}$ & $\begin{array}{l}\text { Não temos gênero; } \\
\text { substantivos não têm gênero. }\end{array}$ \\
\hline emos que é & \\
\hline
\end{tabular}




\begin{tabular}{|c|c|}
\hline $\begin{array}{l}\text { essas coisas quando cad }[\ldots] \text {, como o } \\
\text { tempo, cada tempo. }\end{array}$ & $\begin{array}{l}\text { essas coisas como formas verbais } \\
\text { diferentes, relacionadas com cada } \\
\text { tempo e modo. }\end{array}$ \\
\hline $\begin{array}{l}{[\ldots] \text { qual, qual hora da dia é melhor para }} \\
\text { aprender uma língua, a manhã, a tarde } \\
{[\ldots] \text { ? }}\end{array}$ & $\begin{array}{l}{[\ldots] \text { qual a melhor hora do dia (o }} \\
\text { melhor horário, o melhor período) para } \\
\text { aprender uma língua, de manhã, à tarde } \\
{[\ldots] ?}\end{array}$ \\
\hline $\begin{array}{l}{[\ldots] \text { durante o armorço, durante a noite, }} \\
\text { com que freqüência }[\ldots] \text { ? }\end{array}$ & $\begin{array}{l}{[\ldots] \text { durante o almoço, durante a noite, }} \\
\text { com que freqüência }[. . .] ?\end{array}$ \\
\hline $\begin{array}{l}{[\ldots] \text { que eram os preconcepções sobre o }} \\
\text { Brasil e também a Língua Portuguesa [...] } \\
?\end{array}$ & $\begin{array}{l}\text { [...] Quais eram os preconceitos } \\
\text { (idéias erradas, as más impressões) } \\
\text { sobre o Brasil e também sobre a Língua } \\
\text { Portuguesa [...]? }\end{array}$ \\
\hline $\begin{array}{l}{[\ldots] \text { alguma persoas acham que }[. . .] \text { fica }} \\
\text { igual que Espanhol. }\end{array}$ & $\begin{array}{l}{[\ldots] \text { algumas pessoas acham que é }} \\
\text { igual ao Espanhol. }\end{array}$ \\
\hline $\begin{array}{l}\text { [...] é um mundo deferente aqui que lá. E } \\
\text { este fato de facilidade deve ser } \\
\text { expressado. }\end{array}$ & $\begin{array}{l}{[\ldots] \text { aqui é um mundo diferente de lá. E }} \\
\text { esta questão de facilidade (este fator } \\
\text { "facilidade") deve ser expressada. }\end{array}$ \\
\hline $\begin{array}{l}\text { você deve incluir a palavra "recurso" } \\
\text { porque este é um grande diferência. }\end{array}$ & $\begin{array}{l}\text { Você deve incluir a palavra "recurso" } \\
\text { porque esta é uma grande diferença. }\end{array}$ \\
\hline $\begin{array}{l}{[\ldots] \text { o produto final de este pesquisa vai }} \\
\text { ser uma coisa para o país. }\end{array}$ & $\begin{array}{l}{[\ldots] \text { o resultado final desta pesquisa vai }} \\
\text { ser uma coisa boa (fator importante) } \\
\text { ao país. }\end{array}$ \\
\hline $\begin{array}{l}{[\ldots] \text { talvez deve extrapolar um pouco na }} \\
\text { entrevista sobre as diferências entre São } \\
\text { Paulo; }\end{array}$ & $\begin{array}{l}\text { [...] talvez deva extrapolar (estender-se) } \\
\text { um pouco na entrevista sobre as } \\
\text { diferenças entre São Paulo e outros } \\
\text { estados; }\end{array}$ \\
\hline $\begin{array}{l}{[\ldots] \text { ou se não ou pode ser as }} \\
\underline{\text { concepções da educación do Brasil. }}\end{array}$ & $\begin{array}{l}{[\ldots] \text { ou senão podem ser o(s) }} \\
\text { conceito(s) de cultura do (no) Brasil. }\end{array}$ \\
\hline $\begin{array}{l}\text { [...] uma coisa que fica mais ou menos } \\
\text { igual entre os estudantes brasileiros e } \\
\text { americanos é sua nivel de }[\ldots] \text {, sua } \\
\text { curiosidade; }\end{array}$ & $\begin{array}{l}\text { [...] uma coisa que fica mais ou menos } \\
\text { igual (é bem semelhante) entre os } \\
\text { estudantes brasileiros e americanos é } \\
\text { seu nível de interesse, sua curiosidade; }\end{array}$ \\
\hline $\begin{array}{l}{[\ldots], \text { mas os estudantes americanos são }} \\
\text { muitos ligados a [...] ao educación } \\
\text { mesmo. }\end{array}$ & $\begin{array}{l}{[\ldots], \text { mas os estudantes americanos são }} \\
\text { muito mais ligados ao conhecimento (à } \\
\text { cultura) mesmo. }\end{array}$ \\
\hline $\begin{array}{l}\text { E este tem excepções; eu estou } \\
\text { pensando uma discussión que eu tinha }\end{array}$ & $\begin{array}{l}\text { E isto tem exceções; (eu) estou } \\
\text { pensando numa (me lembrando de uma) } \\
\text { discussão que eu tive aqui durante uma }\end{array}$ \\
\hline
\end{tabular}




\begin{tabular}{|c|c|}
\hline uma aula aqui $[\ldots]$ & aula. \\
\hline $\begin{array}{l}{[\ldots], \text { mas o nível de respeito e de }} \\
\text { atención na }[\ldots . .] \text { nos cursos aqui e a } \\
\frac{\text { concepción da educación }[\ldots] \text { foi pelo }}{\text { menos superficialmente; }}\end{array}$ & $\begin{array}{l}{[\ldots], \text { mas o nível de respeito e (de) }} \\
\text { atenção nos cursos (às aulas) aqui e o } \\
\text { conceito (visão, sentido, significado, } \\
\text { valor) de cultura }[\ldots] \text { foi } \\
\text { superficialmente } \\
\text { (colocado). }\end{array}$ \\
\hline Eu estou aqui sete semais. & Eu estou aqui há sete semanas. \\
\hline $\begin{array}{l}\text { Eu falo assi meio Portinhol, mas já } \\
\text { pacência. }\end{array}$ & $\begin{array}{l}\text { Eu falo assim meio Portunhol, mas [...] } \\
\text { paciência. }\end{array}$ \\
\hline $\begin{array}{l}{[\ldots] \text { fanáticos de futebol, carneval, }[\ldots] \text { é }} \\
\text { impressionante. }\end{array}$ & $\begin{array}{l}{[\ldots] \text { fanáticos por futebol, carnaval, }[\ldots]} \\
\text { é impressionante. }\end{array}$ \\
\hline Eu estou aqui só um año. & Eu estou aqui somente há um ano. \\
\hline [...] non é tempo para ficar com sodade. & $\begin{array}{l}{[\ldots] \text { não é tempo suficiente para ficar }} \\
\text { com saudade. }\end{array}$ \\
\hline [...] estou com outros espicies humanos. & $\begin{array}{l}{[\ldots] \text { estou com outros espécimes }} \\
\text { humanos (outros tipos de pessoas). }\end{array}$ \\
\hline $\begin{array}{l}\text { Tudo é diferente }[\ldots] \text { mas da cultura, da } \\
\text { comida, da temporada }[\ldots]\end{array}$ & $\begin{array}{l}\text { Tudo é diferente }[\ldots] \text { quanto à cultura, à } \\
\text { comida, ao } \quad \text { clima } \\
\text { meteorológico) }[. . .]\end{array}$ \\
\hline E aqui faz um quinte fenomenal. & E aqui faz um calor fenomenal. \\
\hline $\begin{array}{l}\text { Aqui na USP eu fico boba como todos os } \\
\text { estudantes têm interessa na matéria. }\end{array}$ & $\begin{array}{l}\text { Aqui na USP eu fico boba como todos } \\
\text { os estudantes têm interesse pela } \\
\text { matéria (em estudo } \rightarrow \text { disciplina). }\end{array}$ \\
\hline $\begin{array}{l}{[\ldots] \text { aqui todo mundo tem um coragem }} \\
\text { para aprender. }\end{array}$ & $\begin{array}{l}\text { [...] aqui todo mundo tem uma vontade } \\
\text { de aprender. }\end{array}$ \\
\hline [...] é um questión [...] & {$[\ldots]$ é uma questão $[\ldots]$} \\
\hline $\begin{array}{l}{[\ldots] \text { lá onde a policia som policia }} \\
\text { performados. }\end{array}$ & $\begin{array}{l}{[\ldots] \text { lá onde a polícia é composta por }} \\
\text { policiais qualificados. }\end{array}$ \\
\hline $\begin{array}{l}\text { São Paulo é São Paulo, resto do Brasil é } \\
\text { outra coisa. }\end{array}$ & $\begin{array}{l}\text { São Paulo é São Paulo, o restante do } \\
\text { Brasil é outra coisa. }\end{array}$ \\
\hline não é critíco [...] & não é uma crítica. \\
\hline $\begin{array}{l}{[\ldots] \text { coisas que me dan raiva que }[\ldots] \text { ah }} \\
{[\ldots] \text { tráfico - questión da trânsito. }}\end{array}$ & $\begin{array}{l}{[\ldots] \text { coisas que me dão raiva como o }} \\
\text { tráfego - questões de trânsito. }\end{array}$ \\
\hline
\end{tabular}




\begin{tabular}{|c|c|}
\hline Aqui em São Paulo tem tan puder [...] & Aqui em São Paulo tem tanto poder [...] \\
\hline $\begin{array}{l}\text { Maluf fala de qualquer cosa, mas não } \\
\text { lembra di a próxima. }\end{array}$ & $\begin{array}{l}\text { Maluf fala de qualquer coisa, mas não } \\
\text { se lembra do próximo. }\end{array}$ \\
\hline Rossi tem um pouco méruco. & Rossi tem um pouco de mérito. \\
\hline $80 \%$ do poblação é considerada pobre. & $\begin{array}{l}80 \% \text { da população é considerada } \\
\text { pobre. }\end{array}$ \\
\hline [...] estamos entrando no siclo XXI & [...] estamos entrando no século XXI \\
\hline $\begin{array}{l}\text { Como aqui estamos no tempo de } \\
\text { eleições [...] }\end{array}$ & $\begin{array}{l}\text { Como aqui estamos na época de } \\
\text { eleições [...] }\end{array}$ \\
\hline $\begin{array}{l}\text { Qualquer pessoa [...] vai estudar (Inglês) } \\
\text { seis seminas. }\end{array}$ & $\begin{array}{l}\text { Qualquer pessoa [...] vai estudar (Inglês) } \\
\text { por seis semanas. }\end{array}$ \\
\hline meior aportunidade aprender idioma. & $\begin{array}{l}\text { a melhor oportunidade (possibilidade) } \\
\text { de aprender um idioma. }\end{array}$ \\
\hline Eu estou aqui sete semães. & Eu estou aqui há sete semanas. \\
\hline Já passei tiempo no Paraguai. & Já passei algum tempo no Paraguai. \\
\hline $\begin{array}{l}\text { Nunca passei nenhum forma de tiempo } \\
\text { aqui no Brasil. }\end{array}$ & $\begin{array}{l}\text { Nunca passei nenhuma parcela de } \\
\text { (porção de, pouco, período de) tempo } \\
\text { (nenhum tempinho ou, ainda, nem } \\
\text { pouco tempo) aqui no Brasil. }\end{array}$ \\
\hline O sistema de coreo funciona. & O sistema de correios funciona. \\
\hline $\begin{array}{l}\text { Estava falando da cosa totalmente } \\
\text { diferente. }\end{array}$ & $\begin{array}{l}\text { Estava falando de uma coisa totalmente } \\
\text { diferente. }\end{array}$ \\
\hline $\begin{array}{l}{[\ldots] \text { Brasil tan lindo e da repente um }} \\
\text { cidade assi grande, perículo }[\ldots]\end{array}$ & $\begin{array}{l}{[\ldots] \text { Brasil tão lindo e de repente (tem) }} \\
\text { uma cidade assim grande, com tanto } \\
\text { perigo [...] (perigosa, periculosa, com } \\
\text { periculosidade) }\end{array}$ \\
\hline Eu preciso um cassa, um família [...] & $\begin{array}{l}\text { Eu preciso de uma casa, de uma } \\
\text { família }[\ldots . .]\end{array}$ \\
\hline No sê que algo bobage $[\ldots]$ & $\begin{array}{l}\text { Não sei Qual a bobagem (a que se } \\
\text { destina) }[. . .] \\
\text { ou } \\
\text { Não sei a que coisa boba (isto se } \\
\text { destina) [...] }\end{array}$ \\
\hline
\end{tabular}




\begin{tabular}{|c|c|}
\hline $\begin{array}{l}\text { Em esta sala a janela é igual que } \\
\text { qualquer outra janela do edifício. }\end{array}$ & $\begin{array}{l}\text { Nesta sala a janela é igual a qualquer } \\
\text { outra do prédio. }\end{array}$ \\
\hline $\begin{array}{l}\text { Beleza natural }[. . .] \text {, aqui em Brasil, que } \\
\text { você tem }[. . .] \text {, agradesco lhes deram. }\end{array}$ & $\begin{array}{l}\text { Beleza natural }[\ldots] \text {, aqui no Brasil, que } \\
\text { vocês têm }[\ldots] \text {, um agradecimento } \\
\text { (que todos deveriam fazer) pela dádiva } \\
\text { (graça) que lhes deram. }\end{array}$ \\
\hline Acho que o mundo tem pouco paciência. & $\begin{array}{l}\text { Acho que todo mundo tem pouca } \\
\text { paciência. }\end{array}$ \\
\hline $\begin{array}{l}\text { Todo mundo me conhecia lá perto da mia } \\
\text { bairo. }\end{array}$ & $\begin{array}{l}\text { Todo mundo me conhecia lá perto do } \\
\text { meu bairro. }\end{array}$ \\
\hline $\begin{array}{l}([\ldots] \quad \text { morar sozinha?) Depende } \\
\text { totalmente da personas. }\end{array}$ & Depende totalmente da pessoa. \\
\hline $\begin{array}{l}\text { Ficar assi poco agitado, nervoso, non } \\
\text { funciona fora da sua identidade. }\end{array}$ & $\begin{array}{l}\text { Ficar assim um pouco agitado, nervoso, } \\
\text { não funciona (não dá certo), (pois você } \\
\text { está) fora de seu juízo perfeito. }\end{array}$ \\
\hline $\begin{array}{l}\text { Qualquer cidade maior grande do mundo } \\
\text { hay perigro. }\end{array}$ & $\begin{array}{l}\text { Qualquer grande cidade do mundo tem } \\
\text { perigo. }\end{array}$ \\
\hline $\begin{array}{l}{[\ldots] \text { a gente siempre tem que tomar }} \\
\text { cuidado, juízo, estar alerta. }\end{array}$ & $\begin{array}{l}{[\ldots] \text { a gente sempre tem de tomar }} \\
\text { cuidado, ter responsabilidade } \\
\text { (atenção), estar alerta. }\end{array}$ \\
\hline Ela está entrenimiento para esquiar. & $\begin{array}{l}\text { Ela está em treinamento para esquiar } \\
\text { (para tornar-se profissional). }\end{array}$ \\
\hline $\begin{array}{l}\text { Estou conseguiendo [...] amigos, gente } \\
\text { boa, coisas do means. }\end{array}$ & $\begin{array}{l}\text { Estou conseguindo }[\ldots] \text { amigos, gente } \\
\text { boa, coisas do cotidiano. }\end{array}$ \\
\hline $\begin{array}{l}{[\ldots] \text { o questión da falar contra govierno }} \\
\text { com música. }\end{array}$ & $\begin{array}{l}{[\ldots] \text { a questão de falar contra o }} \\
\text { governo através da música. }\end{array}$ \\
\hline $\begin{array}{l}\text { Lá esso os brasileiros conseguiram um } \\
\text { basse na [...] da música. }\end{array}$ & $\begin{array}{l}\text { Lá (no show) os brasileiros conseguiram } \\
\text { isso: fazer da música um veículo } \\
\text { (liberdade para fazer denúncias políticas } \\
\text { através da música). }\end{array}$ \\
\hline $\begin{array}{l}\text { Madona não tinha educação, não } \\
\text { educação como "manners", mas como } \\
\text { estudos. }\end{array}$ & $\begin{array}{l}\text { Madona não tinha educação, não } \\
\text { educação como comportamento, mas } \\
\text { como cultura. }\end{array}$ \\
\hline $\begin{array}{l}\text { Tem uma música aqui. Ficar na minha } \\
\text { cabeça. }\end{array}$ & $\begin{array}{l}\text { Há uma música aqui, que ficou na minha } \\
\text { mente (memória). }\end{array}$ \\
\hline $\begin{array}{l}{[\ldots] \text { como uma semana eu tenho essas }} \\
\text { duas líricas só. Assi ficar na minha }\end{array}$ & $\begin{array}{l}{[\ldots] \text { há uma semana eu estou com }} \\
\text { essas duas palavras, que ficaram na }\end{array}$ \\
\hline
\end{tabular}




\begin{tabular}{|c|c|}
\hline cabeça. & minha mente. \\
\hline $\begin{array}{l}{[\ldots] \text { um govierno }[\ldots] \text { um governador lá }} \\
\text { no quiso ser governador }[\ldots]\end{array}$ & $\begin{array}{l}{[\ldots] \text { um (chefe de) governo }[\ldots] \text { um }} \\
\text { governador lá não quis governar }[\ldots]\end{array}$ \\
\hline $\begin{array}{l}{[\ldots] \text { um governador lá no quiso ser }} \\
\text { governador da classe alta e ja quiso } \\
\text { tomar um }[\ldots] \text { assi um, a cultura }[\ldots] \text { a } \\
\text { cultura negra da [...] dos Estados Unidos. }\end{array}$ & $\begin{array}{l}\text { [...] um governador (uma pessoa) lá não } \\
\text { quis ser governador da classe alta e } \\
\text { então quis atender (dedicar-se à) a } \\
\text { sociedade negra dos Estados Unidos. }\end{array}$ \\
\hline 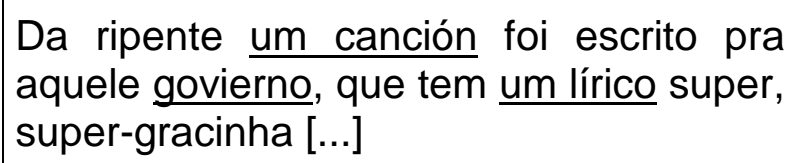 & $\begin{array}{l}\text { De repente uma canção foi escrita para } \\
\text { aquele governo, que tem uma letra } \\
\text { super, super-gracinha }[\ldots]\end{array}$ \\
\hline $\begin{array}{l}{[\ldots] \text { porque etá falando da alguém }[\ldots] \text { da }} \\
\text { cultura, da }[\ldots . .] \text { da classe alta, né? E os } \\
\text { líricos são (começa a cantar }[\ldots]) \text {. }\end{array}$ & $\begin{array}{l}\text { [...] porque está falando de alguém da } \\
\text { sociedade, da classe alta (alta } \\
\text { sociedade), né? E os versos são } \\
\text { (começa a cantar }[\ldots]) \text {. }\end{array}$ \\
\hline $\begin{array}{l}{[\ldots] \text { num favela, né? [...] e um super-star }} \\
\text { com super - no sê como }[\ldots] \text { estrela } \\
\text { super, né? }\end{array}$ & $\begin{array}{l}{[\ldots] \text { (alguém) da favela, né? e (se }} \\
\text { transformou) em uma super-estrela, } \\
\text { não sei como (formar, traduzir uma } \\
\text { palavra) com super }[. . .] \text { estrela super, } \\
\text { né? }\end{array}$ \\
\hline $\begin{array}{l}\text { E para [...] como eu não consegui bolsa } \\
\text { estudar aqui no Brasil, eu tinha que } \\
\text { vender meu cavalo. }\end{array}$ & $\begin{array}{l}\text { E como eu não consegui uma bolsa de } \\
\text { estudos aqui no Brasil, eu tive de } \\
\text { vender meu cavalo. }\end{array}$ \\
\hline $\begin{array}{l}{[\ldots] \text { mas foi una cosa }[\ldots] \text { ai }[\ldots]} \\
\text { lágrimas de esso, eu vou ficar assi um } \\
\text { pouco trista. }\end{array}$ & $\begin{array}{l}{[\ldots] \text { mas foi uma coisa }[\ldots] \text { ai }[\ldots] \text { isso }} \\
\text { me faz chorar; eu vou ficar assim um } \\
\text { pouco triste. } \\
{[\ldots] \text { mas foi uma coisa }[. . .] \text { ai }[\ldots] \text { isso }} \\
\text { me dá vontade de chorar; eu vou ficar } \\
\text { assim um pouco triste. } \\
{[\ldots] \text { mas foi uma coisa }[. . .] \text { ai }[. . .] \text { eu }} \\
\text { começo a chorar (começam a sair } \\
\text { lágrimas) por isso; eu vou ficar assim } \\
\text { um pouco triste. }\end{array}$ \\
\hline $\begin{array}{l}{[\ldots] \text { eu esteve com }[\ldots] \text { eu simpre esteve }} \\
\text { com ele como três horas a dia }[\ldots]\end{array}$ & $\begin{array}{l}{[\ldots] \text { eu sempre ficava com ele três }} \\
\text { horas por dia }[\ldots]\end{array}$ \\
\hline $\begin{array}{l}\text { Ela consiguiô um direción de um fazenda } \\
\text { aqui que tem cavalos para alugar. }\end{array}$ & $\begin{array}{l}\text { Ela conseguiu um administrador de } \\
\text { uma fazenda aqui, que tem cavalos } \\
\text { para alugar. }\end{array}$ \\
\hline [...] eu fiquei doente da saudade e da & [...] eu fiquei doente de saudade e de \\
\hline
\end{tabular}




\begin{tabular}{|c|c|}
\hline lástima. & tristeza (de dor). \\
\hline $\begin{array}{l}\text { Lá os cavalos eram magros, doente, têm } \\
\text { bichos }[. . .]\end{array}$ & $\begin{array}{l}\text { Lá os cavalos eram magros, doentes, } \\
\text { têm bichos (micróbios) [...] }\end{array}$ \\
\hline $\begin{array}{l}{[\ldots] \text { e o dono era do interior, de Minos }} \\
\text { Gerais; ele era uma artista demais. }\end{array}$ & $\begin{array}{l}{[\ldots] \text { e o dono era do interior, de Minas }} \\
\text { Gerais; ele era um grande (excelente) } \\
\text { artista. }\end{array}$ \\
\hline $\begin{array}{l}\text { Eu coloquei o mais gran }[\ldots] \text {, o mais } \\
\text { melior do estavo. }\end{array}$ & $\begin{array}{l}\text { Eu coloquei o maior, o melhor do } \\
\text { estábulo. }\end{array}$ \\
\hline $\begin{array}{l}\text { Da ripente }- \text { num cila, cel }[\ldots] \text { cila }[\ldots] \\
\text { coisa onde }[\ldots] \text { cila }- \text { aquele negócio } \\
\text { onde }[\ldots] \text { eu quero }[\ldots] \text { fico no cavalo } \\
\text { bom. }\end{array}$ & $\begin{array}{l}\text { De repente - numa cela, a coisa onde } \\
{[\ldots] \text { - aquele negócio onde eu fico bem }} \\
\text { no cavalo. }\end{array}$ \\
\hline $\begin{array}{l}{[\ldots] \text { não é como os filmes americano. O }} \\
\underline{\text { West }- \text { nada é assim. }}\end{array}$ & $\begin{array}{l}{[\ldots] \text { não é como os filmes americanos - }} \\
\text { o oeste - não é nada assim. }\end{array}$ \\
\hline $\begin{array}{l}\text { (falando sobre equitação). Eu acho que é } \\
\text { uma coisa maravilhosa; eu sei que una } \\
\text { [...] um esporte da riqueza; }\end{array}$ & $\begin{array}{l}\text { Eu acho que é uma coisa maravilhosa; } \\
\text { eu sei que é um esporte de rico (da } \\
\text { classe alta); }\end{array}$ \\
\hline $\begin{array}{l}\text { Meus pais nunca me ajudaram com } \underline{0} \\
\text { coisa da cavalo }[\ldots]\end{array}$ & $\begin{array}{l}\text { Meus pais nunca me ajudaram com } \\
\text { essa coisa de cavalo }[. . .]\end{array}$ \\
\hline $\begin{array}{l}{[\ldots] \text { o coisa }[\ldots] \text { depois estudos, né? Mas }} \\
\text { eu tinha una adictação }-\underline{\text { addiction }[\ldots]}\end{array}$ & $\begin{array}{l}{[\ldots] \text { (eu colocava) essa coisa (em }} \\
\text { primeiro lugar), depois estudos, né? Mas } \\
\text { eu tinha uma adoração (veneração, } \\
\text { apego, vício, paixão, obsessão) [...] }\end{array}$ \\
\hline $\begin{array}{l}{[\ldots] \text { eu tinha doze anos e eu conheci } \underline{0}} \\
\text { savor quando os dos cabeças funcionam } \\
\text { juntos. }\end{array}$ & $\begin{array}{l}\text { [...] eu tinha doze anos e eu conheci o } \\
\text { sabor (o prazer, a realização, a } \\
\text { satisfação) quando as duas cabeças } \\
\text { (a dela e a do cavalo) funcionam juntas. }\end{array}$ \\
\hline $\begin{array}{l}\text { Como eu tengo dentro mia cabeça }[. . .] \\
\text { tengo tanta preocupas porque eu salto. }\end{array}$ & $\begin{array}{l}\text { Como eu tenho (trago) isso na minha } \\
\text { mente (no meu pensamento) [...] tenho } \\
\text { muita preocupação porque eu salto. } \\
\text { Isso se torna uma idéia fixa; me dá } \\
\text { muita preocupação porque eu salto. }\end{array}$ \\
\hline $\begin{array}{l}{[\ldots] \text { e quando os doas cabeças funciona }} \\
\text { juntos, alguma coisa maravilhosa; é um } \\
\text { sabor melhor que chocolate. }\end{array}$ & $\begin{array}{l}{[\ldots] \text { e quando as duas cabeças }} \\
\text { funcionam juntas, é alguma coisa } \\
\text { maravilhosa; é um sabor (prazer) } \\
\text { melhor que chocolate. }\end{array}$ \\
\hline $\begin{array}{l}\text { Demais eu quero conhecer a uma persoa } \\
\text { que me pode, não sei, indicar [...] }\end{array}$ & $\begin{array}{l}\text { Eu quero muito conhecer uma pessoa } \\
\text { que me possa, não sei, indicar [...] }\end{array}$ \\
\hline
\end{tabular}




\begin{tabular}{|c|c|}
\hline $\begin{array}{l}{[\ldots] \text { porque lá é como eu fez: assi }[\ldots]} \\
\text { equitaçón clássica }[\ldots]\end{array}$ & $\begin{array}{l}{[\ldots] \text { porque lá é como eu fiz: assim }[\ldots]} \\
\text { equitação clássica }[\ldots]\end{array}$ \\
\hline Essos que eu gosto. & Disso (dessas coisas) que eu gosto. \\
\hline $\begin{array}{l}{[\ldots] \text { meu pai tem um pouco de sangue, }} \\
\text { acho que irlandesa. }\end{array}$ & $\begin{array}{l}\text { Acho que meu pai tem um pouco de } \\
\text { sangue irlandês. }\end{array}$ \\
\hline Estudei mais sociologia e idioma. & $\begin{array}{l}\text { Estudei mais sociologia e idiomas } \\
\text { (línguas). }\end{array}$ \\
\hline $\begin{array}{l}\text { (Estudei) sociologia, muito a literatura, } \\
\text { também, demais, [...] }\end{array}$ & $\begin{array}{l}\text { (Estudei) sociologia, muito literatura } \\
\text { (bastante literatura), também, demais, } \\
{[\ldots]}\end{array}$ \\
\hline $\begin{array}{l}{[\ldots] \text { então ele me ensinou, que me }[\ldots]} \\
\text { primeiras palavras de Português, a } \\
\text { samba }[\ldots]\end{array}$ & $\begin{array}{l}{[\ldots] \text { então ele me ensinou, as primeiras }} \\
\text { palavras do Português, o samba }[. . .]\end{array}$ \\
\hline $\begin{array}{l}{[\ldots] \text { então precisava esperar }} \\
\text { atéFaculdade. }\end{array}$ & $\begin{array}{l}{[\ldots] \text { então precisava esperar até a }} \\
\text { Faculdade. }\end{array}$ \\
\hline $\begin{array}{l}\text { [...] porque a Faculdade tem que aceitar } \\
\text { tudo, todo curso assi; }\end{array}$ & $\begin{array}{l}\text { [...] porque a Faculdade tem de aceitar } \\
\text { (reconhecer) tudo, todos os cursos } \\
\text { assim (necessários, exigidos); }\end{array}$ \\
\hline [...] tem muito burocracia. & [...] há muita burocracia. \\
\hline $\begin{array}{l}\text { Antes eu trabalhava numa loja K-mart } \\
\text { assi para ser a woman. }\end{array}$ & $\begin{array}{l}\text { Antes eu trabalhava numa loja K-mart } \\
\text { assim para ser a recepcionista. }\end{array}$ \\
\hline $\begin{array}{l}{[\ldots] \text { no Brasil uma coisa pode ser a }} \\
\underline{\text { sacanagem, mas para mim não é; }}\end{array}$ & $\begin{array}{l}{[\ldots] \text { no Brasil uma coisa pode ser uma }} \\
\text { malandragem (uma safadeza), mas } \\
\text { para mim não é; }\end{array}$ \\
\hline $\begin{array}{l}\text { Tinha que ter umas conexões mais } \\
\text { fortes. }\end{array}$ & $\begin{array}{l}\text { Tinha de ter umas amizades mais } \\
\text { fortes. }\end{array}$ \\
\hline $\begin{array}{l}\text { Agora tenho uma conexão superlegal } \\
\text { com minha família hospedeira, }[. . .]\end{array}$ & $\begin{array}{l}\text { Agora tenho uma relação (um } \\
\text { convívio, uma amizade) superlegal } \\
\text { com minha família hospedeira. }\end{array}$ \\
\hline $\begin{array}{l}{[\ldots] \text { parece que os brasileiros têm muito }} \\
\text { interesse em ser meu amigo Quando [...] }\end{array}$ & $\begin{array}{l}{[\ldots] \text { parece que os brasileiros têm muito }} \\
\text { interesse em ser meus amigos (pela } \\
\text { minha amizade) quando }[. . .]\end{array}$ \\
\hline $\begin{array}{l}{[\ldots] \text { é mais show, mas uma coisa }} \\
\text { verdadeira, não. }\end{array}$ & $\begin{array}{l}\text { [...] é mais encenação e não uma coisa } \\
\text { verdadeira. }\end{array}$ \\
\hline [...] sempre saía com ele: levava ele & [...] sempre saía com ele: levava-o para \\
\hline
\end{tabular}




\begin{tabular}{|c|c|}
\hline para lugar, para sair [...] & (os) lugares, para sair [...] \\
\hline $\begin{array}{l}{[\ldots] \text { e quando saiu só para falar Inglês; }} \\
\text { para [...] para me levar a lugar e ele só } \\
\text { falava em Inglês }[\ldots]\end{array}$ & $\begin{array}{l}{[\ldots] \text { e quando saiu foi só para falar }} \\
\text { Inglês; para me levar a um lugar e ele } \\
\text { só falava em Inglês [...] }\end{array}$ \\
\hline Interessante [...] tem muito coisa. & Interessante $[\ldots]$ tem muita coisa. \\
\hline $\begin{array}{l}{[\ldots] \text { e eu acho muito interessante a }} \\
\text { sexualidade no Brasil, porque tem muito } \\
\text { ênfase a sexualidade [...] }\end{array}$ & $\begin{array}{l}{[\ldots] \text { e eu acho muito interessante a }} \\
\text { Sexualidade no Brasil, porque dão muito } \\
\text { valor a ela [...] }\end{array}$ \\
\hline $\begin{array}{l}{[\ldots] \text { e, muitas vezes, em saia bem }} \\
\text { curtinho. }\end{array}$ & $\begin{array}{l}{[\ldots] \text { e, muitas vezes, com saia bem }} \\
\text { curtinha. }\end{array}$ \\
\hline$\underline{\text { A coisa que homem fala na rua }[\ldots]}$ & $\begin{array}{l}\text { As coisas que os homens falam na rua } \\
{[\ldots]}\end{array}$ \\
\hline Só latino chega e falam isso. & Só os latinos chegam e falam isso. \\
\hline $\begin{array}{l}\text { Que } \\
\text { Que injustiça }\end{array}$ & Que injustiça \\
\hline Paguei demais, exageradamente & $\begin{array}{l}\text { Paguei demais, um exagero (uma } \\
\text { quantia exagerada) }\end{array}$ \\
\hline $\begin{array}{l}\text { [...] querem falar só Inglês. Só Inglês } \\
\text { exagerado }\end{array}$ & $\begin{array}{l}\text { [...] querem falar só Inglês. Só Inglês a } \\
\text { toda hora (a todo momento) }\end{array}$ \\
\hline [...] tem um curso que viagem & $\begin{array}{l}\text { há um curso sobre viagem (para } \\
\text { viagens) }\end{array}$ \\
\hline Então a gente ficou lá esperando & $\begin{array}{l}\text { Então o pessoal (as pessoas) ficou lá } \\
\text { esperando }\end{array}$ \\
\hline $\begin{array}{l}\text { [...] não é porque a político aqui culto, } \\
\text { âssi }\end{array}$ & $\begin{array}{l}{[\ldots . .] \text { não é porque o político aqui é }} \\
\text { inculto, não }\end{array}$ \\
\hline $\begin{array}{l}{[\ldots] \text { achar } \underline{\text { ninguém }} \text { que quer falar }} \\
\text { Português com você }\end{array}$ & $\begin{array}{l}{[\ldots] \text { achar alguém que queira falar }} \\
\text { Português com você }\end{array}$ \\
\hline$[\ldots]$ as coisas do Banco & [...] (as) coisas de Banco \\
\hline [...] e comprei a semana & {$[\ldots]$ e comprei o semestre } \\
\hline Brasileiro não pagou & O brasileiro não pagou \\
\hline não tenho nenhum [...] direitos & não tenho nenhum direito \\
\hline coisa que eu acho necessidade de $[. .$.$] de$ & Coisas que eu acho necessário ter \\
\hline
\end{tabular}




\begin{tabular}{|c|c|}
\hline $\begin{array}{l}\text { (ter) } \\
\text { coisas que eu acho necessário Ter }\end{array}$ & \\
\hline $\begin{array}{l}{[\ldots] \text { que eu tenho a direito, a acesso às }} \\
\text { coisas }[\ldots]\end{array}$ & $\begin{array}{l}{[\ldots] \text { que eu tenha direito, acesso às }} \\
\text { coisas }[\ldots] \\
{[\ldots] \text { que eu tenha direito de acesso às }} \\
\text { coisas }[\ldots]\end{array}$ \\
\hline $\begin{array}{l}\text { [...] outro sistema de vivir, outro sistema } \\
\text { de política }\end{array}$ & $\begin{array}{l}{[\ldots] \text { outro sistema de vida, outro }} \\
\text { sistema político }\end{array}$ \\
\hline $\begin{array}{l}{[\ldots] \text { essa mulher que é uma nível alta de }} \\
\text { Inglês }\end{array}$ & $\begin{array}{l}{[\ldots] \text { essa mulher que dava um curso de }} \\
\text { Inglês de nível alto (avançado) }\end{array}$ \\
\hline o brasileiro conhece muito palavra & $\begin{array}{l}\text { o(s) brasileiro(s) conhece }(\mathrm{m}) \text { muitas } \\
\text { palavras }\end{array}$ \\
\hline $\begin{array}{l}\text { [...] que brasileiro sabe monte de } \\
\text { palavras, mas }[\ldots]\end{array}$ & $\begin{array}{l}{[\ldots] \text { que o brasileiro sabe (conhece) um }} \\
\text { monte de palavras, mas }[\ldots]\end{array}$ \\
\hline $\begin{array}{l}{[\ldots] \text { mas isso não quer dizer que você }} \\
\text { fala o máximo }\end{array}$ & $\begin{array}{l}{[\ldots] \text { mas isso não quer dizer que você }} \\
\text { fala muito bem }\end{array}$ \\
\hline $\begin{array}{l}{[\ldots] \text { tem que estudar mais, tem uma de } F} \\
{[\ldots] \text { graduar de uma Escola }[\ldots]}\end{array}$ & $\begin{array}{l}{[\ldots] \text { tem de estudar mais, tem de ter }} \\
\text { uma graduação (um certificado, } \\
\text { diploma) de Faculdade }\end{array}$ \\
\hline [...] acho que uma combinação & $\begin{array}{l}\text { [...] acho que os dois (uma soma: } \\
\text { vocabulário e gramática) }\end{array}$ \\
\hline [...] a lírica dela não é boa [...] & {$\left[\begin{array}{l}{[\ldots]} \\
{[\ldots]}\end{array}\right]$ letra das músicas dela não é boa } \\
\hline $\begin{array}{l}\text { (Eu duvido que ela realmente faça essas } \\
\text { coisas); acho que foi um show }[\ldots]\end{array}$ & $\begin{array}{l}\text { (Duvido que ela realmente faça essas } \\
\text { coisas); acho que era uma encenação } \\
{[\ldots]}\end{array}$ \\
\hline $\begin{array}{l}{[\ldots] \text { mas prefiro mais do espírito dela (ele }} \\
\text { sempre vai lá em frente) }\end{array}$ & $\begin{array}{l}\text { [...] mas gosto mais de suas idéias } \\
\text { (avançadas) }\end{array}$ \\
\hline Ah! porque é mui [...] verdade, não é? & $\begin{array}{l}\text { Ah! Porque é uma realidade, não é? } \\
\text { Ah! Porque é bem verdadeira, não é? }\end{array}$ \\
\hline sin saber nada da cultura $[\ldots]$ & $\begin{array}{l}\text { sem saber nada dos (sobre os) hábitos } \\
\text { e costumes }[\ldots]\end{array}$ \\
\hline $\begin{array}{l}\text { Fui muito inocente; não sabia esse de } \\
\text { malandragem }[\ldots]\end{array}$ & $\begin{array}{l}\text { Eu era muito inocente; não conhecia } \\
\text { essa história (essas coisas) de }\end{array}$ \\
\hline
\end{tabular}


malandragem

\subsubsection{Dificuldades relativas aos adjetivos}

\begin{tabular}{|c|c|}
\hline Interlíngua & Língua 2 \\
\hline Demora muito a burocracia aqui. & $\begin{array}{l}\text { A burocracia aqui é muito morosa } \\
\text { (demorada). }\end{array}$ \\
\hline [...] colabora as coisas eficiais. & $\begin{array}{l}{[\ldots] \text { colabora (conosco) para as coisas }} \\
\text { oficiais. }\end{array}$ \\
\hline $\begin{array}{l}{[\ldots] \text { poucos brasileiros conhece a língua }} \\
\text { inglês bem. }\end{array}$ & $\begin{array}{l}{[\ldots] \text { poucos brasileiros conhecem bem a }} \\
\text { língua inglesa'. }\end{array}$ \\
\hline Espanhol e português era para mim fácil & $\begin{array}{l}\text { Espanhol e português foram fáceis } \\
\text { para mim. }\end{array}$ \\
\hline $\begin{array}{l}\text { Acho que São Paulo brasileiros } \\
\text { completamente diferente. }\end{array}$ & $\begin{array}{l}\text { Acho que em São Paulo os brasileiros } \\
\text { são completamente diferentes }\end{array}$ \\
\hline $\begin{array}{l}{[\ldots] \text { os filmes normalmente igual do }} \\
\text { original. }\end{array}$ & $\begin{array}{l}{[\ldots] \text { os filmes são, normalmente, iguais }{ }^{*}} \\
\text { ao original. }\end{array}$ \\
\hline $\begin{array}{l}\text { A falta é em tudos detais na área } \\
\text { turístico. }\end{array}$ & $\begin{array}{l}\text { A falta está em todos os setores } \\
\text { (pontos, locais, contextos) da área } \\
\text { turística. }\end{array}$ \\
\hline $\begin{array}{l}\text { Este coisa de Ensino Inglês no Brasil é } \\
\text { interessante. }\end{array}$ & $\begin{array}{l}\text { A questão (o problema) do Ensino de } \\
\text { Inglês no Brasil é interessante (curiosa, } \\
\text { estranha, confusa, complicada). }\end{array}$ \\
\hline A falta é na área comum, nas ruas. & $\begin{array}{l}\text { A falta está no uso comum (coloquial, } \\
\text { informal, diário), nas ruas (fora da } \\
\text { Embaixada). }\end{array}$ \\
\hline […] só eu estivesse não cassado. & $\begin{array}{l}{[\ldots] \text { (faria isso) só se eu não fosse }} \\
\text { casado. }\end{array}$ \\
\hline $\begin{array}{l}\text { É preciso fazer uma melhoramento } \\
\text { dentro desses áreas do público. }\end{array}$ & $\begin{array}{l}\text { É preciso fazer um melhoramento } \\
\text { (reforma, mudança) nessas áreas } \\
\text { públicas. }\end{array}$ \\
\hline $\begin{array}{l}{[\ldots . .] \text { um sistema pouco mais semelhante }} \\
{[\ldots]}\end{array}$ & {$[\ldots]$ um sistema mais próximo $[\ldots]$} \\
\hline Na alfândega tudo muito demoroso. & $\mathrm{Na}$ alfândega tudo é muito demorado. \\
\hline [...] mas aduana está entraso. & $\begin{array}{l}{[\ldots] \text { mas a aduana esta em atraso }} \\
\text { (atrasada). }\end{array}$ \\
\hline $\begin{array}{l}\text { Todas palavras português têm muito } \\
\text { diferente sentido. }\end{array}$ & $\begin{array}{l}\text { Todas as palavras do português têm } \\
\text { sentidos muito diferentes. }\end{array}$ \\
\hline
\end{tabular}




\begin{tabular}{|c|c|}
\hline Pode ser um gosto muito bom. & Pode ser muito agradável (gostoso). \\
\hline$[\ldots]$ & $\begin{array}{l}\text { [...] e as cidades restantes (no resto do } \\
\text { Brasil) }\end{array}$ \\
\hline $\begin{array}{l}{[\ldots] \text { das culturas moderna dos Estados }} \\
\text { Unidos. }\end{array}$ & $\begin{array}{l}{[\ldots] \text { das culturas modernas dos }} \\
\text { Estados Unidos. }\end{array}$ \\
\hline $\begin{array}{l}\text { Não } \\
\text { pergi }\end{array}$ & $\begin{array}{l}\text { Não } \\
\text { uma }\end{array}$ \\
\hline $\begin{array}{l}\text { Dura } \\
\text { aprer }\end{array}$ & $\begin{array}{l}\text { Durante minha } \\
\text { aprendi três líng }\end{array}$ \\
\hline as pessoas vivem juntos & $\begin{array}{l}\text { Em São Paulo as pessoas são (mais) } \\
\text { unidas (são mais accessíveis, mais } \\
\text { solidárias). }\end{array}$ \\
\hline As 0 & $\begin{array}{l}\text { As c } \\
\text { (bem }\end{array}$ \\
\hline $\begin{array}{l}{[\ldots] \text { pessoas } d e} \\
\text { humor. }\end{array}$ & {$[\ldots]$} \\
\hline sado. & $\begin{array}{l}\text { Este } \\
\text { (inad }\end{array}$ \\
\hline quer fazer uma & $\begin{array}{l}\text { (um } h \\
\text { bom }\end{array}$ \\
\hline $\begin{array}{l}{[\ldots] \text { mas agora uma das áreas onde }} \\
\text { inglês é conhecido. }\end{array}$ & $\begin{array}{l}{[\ldots] \text { mas agora (somente) nas áreas }} \\
\text { onde inglês é necessário. }\end{array}$ \\
\hline $\begin{array}{l}\text { Às vezes eu tenho um livro muito } \\
\text { engraçado. }\end{array}$ & $\begin{array}{l}\text { Às vezes eu leio um livro muito } \\
\text { engraçado } \\
\text { diferente). }\end{array}$ \\
\hline $\begin{array}{l}{[\ldots] \text { cada processo estam pequenho }} \\
\text { diferência. }\end{array}$ & $\begin{array}{l}{[\ldots] \text { cada processo apresentava uma }} \\
\text { pequena diferença. }\end{array}$ \\
\hline $\begin{array}{l}{[\ldots] \text { mas estam diferência significar, }} \\
\text { muito significar }[\ldots]\end{array}$ & $\begin{array}{l}{[\ldots] \quad \text { mas são diferenças muito }} \\
\text { significativas. }\end{array}$ \\
\hline $\begin{array}{l}\text { - geralmente as pessoas está muito } \\
\text { simpático. }\end{array}$ & $\begin{array}{l}\text { - geralmente as pessoas são muito } \\
\text { simpáticas (amáveis, agradáveis, } \\
\text { gentis). }\end{array}$ \\
\hline $\begin{array}{l}\text { Eu tenho }[\ldots] \text { e estou nervioso sobre o } \\
\text { programa. }\end{array}$ & $\begin{array}{l}\text { Eu estou nervosa (preocupada, } \\
\text { apreensiva) com o programa. }\end{array}$ \\
\hline $\begin{array}{l}{[\ldots] \quad \text { o causa esta contratos, mas }} \\
\text { realmente }[\ldots] \text { geralmente tudos está } \\
\text { tranqüilo, }[\ldots]\end{array}$ & $\begin{array}{l}\text { [...] quanto a estes contratos realmente } \\
\text { tudo está tranqüilo (decido, definido, } \\
\text { sem problemas, em ordem). }\end{array}$ \\
\hline $\begin{array}{l}\text { Eu acho que a cultura aqui está muito } \\
\text { relaxando. }\end{array}$ & $\begin{array}{l}\text { Eu acho que a c } \\
\text { relaxada. }\end{array}$ \\
\hline o tem [...] nós preferimos & nós do Conselho $p$ \\
\hline
\end{tabular}




\begin{tabular}{|c|c|}
\hline tem contratos papel. & contratos por escrito (assinados). \\
\hline Esto uma história muito interessante. & $\begin{array}{l}\text { Esta é uma história muito complicada } \\
\text { (problemática). }\end{array}$ \\
\hline $\begin{array}{l}{[\ldots] \text { aprendendo uma língua está muito }} \\
\text { psicolôgia, muito [...] }\end{array}$ & $\begin{array}{l}{[\ldots] \text { aprender uma língua é muito }} \\
\text { psicológico, muito [...] }\end{array}$ \\
\hline $\begin{array}{l}{[\ldots] \text { nós tínhamos uma linha segunda em }} \\
\text { casa. }\end{array}$ & $\begin{array}{l}{[\ldots] \text { nós tínhamos uma segunda linha }} \\
\text { em casa. }\end{array}$ \\
\hline $\begin{array}{l}{[\ldots] \text { os motoristas do Brasil também é }} \\
\text { muito perigoso. }\end{array}$ & 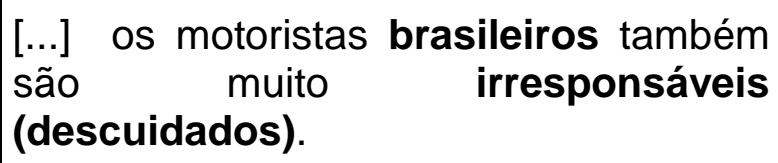 \\
\hline Aqui os ônibus ser [...] & $\begin{array}{l}\text { Aqui os ônibus são incômodos } \\
\text { (problemáticos). }\end{array}$ \\
\hline [...] trânsito é assim [...] & [...] o trânsito é assim confuso \\
\hline $\begin{array}{l}\text { Em Londres nós temos uma sistema } \\
\text { muito safisticado, do maior do mundo. }\end{array}$ & $\begin{array}{l}\text { Em Londres nós temos um sistema } \\
\text { muito sofisticado, o melhor do mundo. }\end{array}$ \\
\hline $\begin{array}{l}{[\ldots] \text { do maior do mundo }[\ldots] \text { por }} \\
\text { comparação não está justaas vezes. }\end{array}$ & $\begin{array}{l}{[\ldots] \text { o melhor do mundo }[\ldots] \text { esta }} \\
\text { comparação não é adequada } \\
\text { (procedente) às vezes. }\end{array}$ \\
\hline $\begin{array}{l}{[\ldots] \text { Inglaterra tem uma rede dos trens, }} \\
\text { rede dos ônibus }[\ldots]\end{array}$ & $\begin{array}{l}{[\ldots] \text { a Inglaterra tem uma rede de trens, }} \\
\text { uma rede de ônibus }[. . .]\end{array}$ \\
\hline $\begin{array}{l}\text { São Paulo tem o festa do filmes jurídica } \\
\text { muito interessante. }\end{array}$ & $\begin{array}{l}\text { São Paulo tem o festival de filmes para } \\
\text { julgamento (crítica) dos mesmos, o } \\
\text { qual é muito interessante. }\end{array}$ \\
\hline $\begin{array}{l}\text { Eu acho que ele tinha uma trabalho muito } \\
\text { interessante. }\end{array}$ & $\begin{array}{l}\text { Eu acho que ele fez um trabalho muito } \\
\text { bom (atuante, significativo). }\end{array}$ \\
\hline $\begin{array}{l}{[\ldots] \text { mas três anos passado eles não têm }} \\
\text { numa sistema bem. }\end{array}$ & $\begin{array}{l}{[\ldots] \text { mas há três anos eles não tinham }} \\
\text { uma bom sistema (de informação). }\end{array}$ \\
\hline $\begin{array}{l}\text { (ele perdió as malas); este uma grande } \\
\text { problema. }\end{array}$ & $\begin{array}{l}\text { (ele perdeu as malas); isto foi um } \\
\text { problema sério. }\end{array}$ \\
\hline $\begin{array}{l}\text { Meu VIP chegou atrasado, sem os } \\
\text { roupas formals. }\end{array}$ & $\begin{array}{l}\text { Meu VIP chegou atrasado, sem as } \\
\text { roupas formais. }\end{array}$ \\
\hline $\begin{array}{l}{[\ldots] \text { ele fuê uma homem muito mais alto }} \\
\text { com ombres }[\ldots]\end{array}$ & $\begin{array}{l}{[\ldots] \text { ele era um homem muito mais alto }} \\
\text { com ombros [...] (largos). }\end{array}$ \\
\hline $\begin{array}{l}{[\ldots] \text { e nós realmente nós tém bem }} \\
\text { sucesso com os roupas formal, meo }[\ldots]\end{array}$ & $\begin{array}{l}{[\ldots] \text { e nós realmente fizemos um }} \\
\text { sucesso total com as minhas (nossas) } \\
\text { roupas formais. }\end{array}$ \\
\hline $\begin{array}{l}{[\ldots] \text { até jantar nós fomos muito }} \\
\text { descansada. }\end{array}$ & $\begin{array}{l}{[\ldots] \text { até no jantar nós ficávamos muito }} \\
\text { quietos (mudos, calados). }\end{array}$ \\
\hline $\begin{array}{l}{[\ldots] \text { nós aprendemos só gramática, sem }} \\
\text { vocabulário. }\end{array}$ & $\begin{array}{l}\text { [...] nós aprendíamos muita gramática, } \\
\text { pouco vocabulário (insuficiente). }\end{array}$ \\
\hline [...] porque as pessoas do Brasil estão & [...] embora os bras \\
\hline
\end{tabular}




\begin{tabular}{|c|c|}
\hline muito simpático com estrangeiros. & $\begin{array}{l}\text { amáveis (atenciosos) } \\
\text { estrangeiros. }\end{array}$ \\
\hline$[\ldots]$ se você tem o vocabulário bem $[\ldots]$ & $\begin{array}{l}{[\ldots] \text { se a gente tem (conhece) um bom }} \\
\text { vocabulário }[\ldots]\end{array}$ \\
\hline $\begin{array}{l}{[\ldots] \text { a gramática é necessário, mas a }} \\
\text { início o vocabulário é melhor. }\end{array}$ & $\begin{array}{l}\text { [...] a gramática é necessária, mas no } \\
\text { início o vocabulário é mais importante. }\end{array}$ \\
\hline $\begin{array}{l}{[\ldots] \text { (por duas horas cada semana) mas }} \\
\text { eu acho que não está bastante. }\end{array}$ & $\begin{array}{l}{[\ldots] \text { (duas aulas por semana) mas eu }} \\
\text { acho que não era (é) suficiente. }\end{array}$ \\
\hline $\begin{array}{l}{[\ldots] \text { ele realmente obsessão com o }} \\
\text { subjuntivo. }\end{array}$ & $\begin{array}{l}{[\ldots] \text { ela era realmente obcecada pelo }} \\
\text { subjuntivo. }\end{array}$ \\
\hline $\begin{array}{l}{[\ldots] \text { eu aprende português da rua com os }} \\
\text { lojas }[\ldots]\end{array}$ & $\begin{array}{l}{[\ldots] \text { eu aprendi português coloquial }} \\
\text { (cotidiano, diário) com os lojistas, etc. }\end{array}$ \\
\hline $\begin{array}{l}\text { Eu não tem certeza }[\ldots] \text { Eu estou } \\
\text { nervioso você vai usar por uma outra } \\
\text { assunto }[\ldots]\end{array}$ & $\begin{array}{l}\text { Eu não estou segura (tranqüila, à } \\
\text { vontade) [...] Eu estou preocupada } \\
\text { porque você pode usar (esta entrevista) } \\
\text { para uma outra finalidade [...] }\end{array}$ \\
\hline $\begin{array}{l}{[\ldots] \text { mas cada processo estam }} \\
\text { pequeninho diferência, mas estam } \\
\text { diferência significar, muito significar }[\ldots]\end{array}$ & $\begin{array}{l}{[\ldots] \text { mas cada processo apresentava }} \\
\text { pequenina diferença significativa, } \\
\text { muito significativa }[. .]\end{array}$ \\
\hline $\begin{array}{l}\text { Se você não fala português bem, você } \\
\text { não tem autoridade bem. }\end{array}$ & $\begin{array}{l}\text { Se você não fala bem o português, você } \\
\text { não mantém uma boa autoridade } \\
\text { (autoridade real, firme). }\end{array}$ \\
\hline $\begin{array}{l}{[\ldots] \text { talvez aprenda uma [...] a História do }} \\
\text { Brasil é muito interessante. }\end{array}$ & $\begin{array}{l}{[\ldots] \text { talvez aprender a História do Brasil }} \\
\text { seja muito necessário. }\end{array}$ \\
\hline Você tem uma re & $\begin{array}{l}\text { Você tem um encontro (reunião) muito } \\
\text { agradável. }\end{array}$ \\
\hline Eu estou muito $\underline{\mathrm{C}}$ & $\begin{array}{l}\text { Eu estou muito confusa (indecisa } \rightarrow \\
\text { tenho dúvidas a respeito do futuro). }\end{array}$ \\
\hline O litoral de São Paulo é linda. & O litoral de São Pau \\
\hline $\begin{array}{l}\text { Nós temos uma vida cultural muito bom } \\
\text { aqui. }\end{array}$ & $\begin{array}{l}\text { Nós temos uma vida cultural muito boa } \\
\text { aqui. }\end{array}$ \\
\hline Nós temos uma vida muito reanimada. & $\begin{array}{l}\text { Nós temos uma vida superanimada } \\
\text { (muito animada, movimentada, } \\
\text { intensa, ativa). }\end{array}$ \\
\hline Eu tenho uma vida muito confortada aqui. & $\begin{array}{l}\text { Eu tenho uma vida muito confortável } \\
\text { aqui. }\end{array}$ \\
\hline Eu gosto bem dos pessoas do brasileiro. & $\begin{array}{l}\text { Eu gosto bastante das pessoas do } \\
\text { Brasil (das pessoas brasileiras ou dos } \\
\text { brasileiros). }\end{array}$ \\
\hline $\begin{array}{l}\text { ano acadêmico na Inglaterra é } \\
\text { diferência daqui. }\end{array}$ & $\begin{array}{l}\text { O ano acadêmico na Inglaterra é } \\
\text { diferente daqui. }\end{array}$ \\
\hline
\end{tabular}




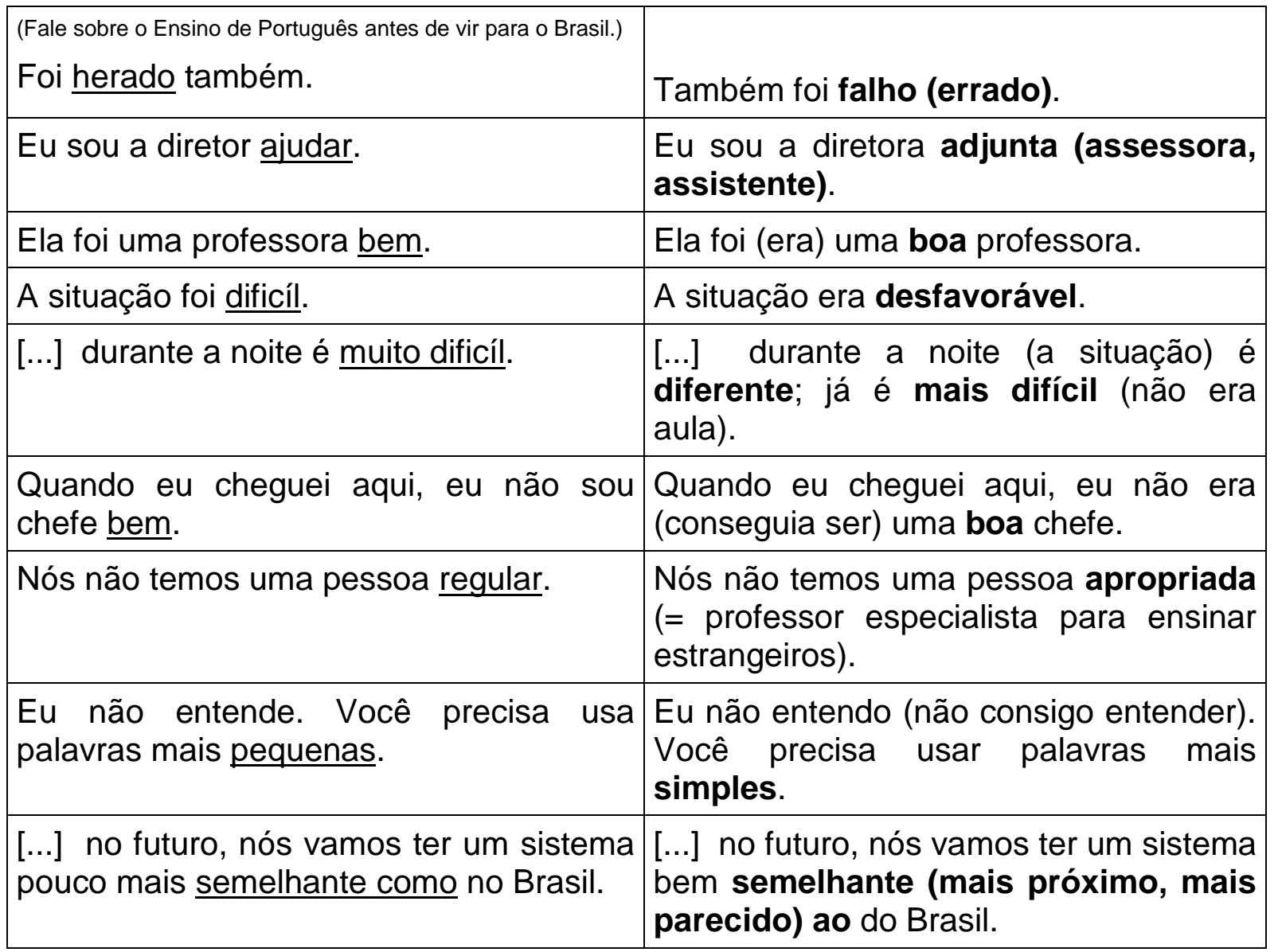

\subsubsection{Dificuldades relativas aos verbos}

\begin{tabular}{|l|l|}
\hline \multicolumn{1}{|c|}{ Interlíngua } & \multicolumn{1}{|c|}{ Língua 2 } \\
\hline Demora muito a burocracia aqui. & $\begin{array}{l}\text { A burocracia aqui é muito morosa } \\
\text { (demorada). }\end{array}$ \\
\hline $\begin{array}{l}\text { Não dá para assimilar como um trabalho } \\
\text { o resto aqui. }\end{array}$ & $\begin{array}{l}\text { Não dá para assumir (encarar) como } \\
\text { um trabalho o restante das coisas aqui. }\end{array}$ \\
\hline Isso es muito diferente. & Isso é muito diferente. \\
\hline (Isso) pode ser para atrapalhar muito. & $\begin{array}{l}\text { (E isso) serve para atrapalhar (acaba } \\
\text { atrapalhando) muito. }\end{array}$ \\
\hline A menos que queira falar perguntando. & $\begin{array}{l}\text { A menos que queira continuar } \\
\text { perguntando. }\end{array}$ \\
\hline Acho que depois será muito melhor. & $\begin{array}{l}\text { Acho que depois tudo ficará muito } \\
\text { melhor. }\end{array}$ \\
\hline Se você perguntar mais uma pergunta. & Se você fizer mais uma pergunta. \\
\hline
\end{tabular}




\begin{tabular}{|c|c|}
\hline [...] dificuldades entra na vida no Brasil. & $\begin{array}{l}\text { [...] dificuldades para começar a vida } \\
\text { no Brasil. }\end{array}$ \\
\hline A Itamarati organizam todos na cidade. & O Itamarati acomoda todos na cidade. \\
\hline $\begin{array}{l}\text { Nós moremos na área de primeiro } \\
\text { mundo. }\end{array}$ & $\begin{array}{l}\text { Nós moramos na área de primeiro } \\
\text { mundo. }\end{array}$ \\
\hline $\begin{array}{l}\text { Eu e minha família ainda não sufre } \\
\text { algumas turmas de violência. }\end{array}$ & $\begin{array}{l}\text { Eu e minha família } \begin{array}{l}\text { ainda } \\
\text { enfrentamos não } \\
\text { assaltantes. }\end{array} \\
\end{array}$ \\
\hline Meu filho atende a Escola Saint Paul. & Meu filho freqüenta a Escola Saint Paul. \\
\hline $\begin{array}{l}\text { [...] trabalho bom para alcançar o país do } \\
\text { Brasil. }\end{array}$ & $\begin{array}{l}{[\ldots] \text { bom trabalho para engrandecer }} \\
\text { (elevar) o Brasil. }\end{array}$ \\
\hline $\begin{array}{l}{[\ldots] \text { parece simples, como expectar }} \\
\text { carro, expectar things pessoais. }\end{array}$ & $\begin{array}{l}\text { [...] que parecem simples, como } \\
\text { aguardar um carro (a liberação de um } \\
\text { carro pela alfândega), aguardar as } \\
\text { coisas pessoais. }\end{array}$ \\
\hline $\begin{array}{l}\text { Nós temos poder para alcançar o Distrito } \\
\text { Federal. }\end{array}$ & $\begin{array}{l}\text { Nós temos poder para solicitar ao } \\
\text { (requerer ao) Distrito Federal. }\end{array}$ \\
\hline $\begin{array}{l}\text { Essas escolas de comunicações - Quick } \\
\text { English - de "language", usando de } \\
\text { Cultura Inglesa, têm muito internacional. }\end{array}$ & $\begin{array}{l}\text { Essas escolas de comunicação - Quick } \\
\text { English - (escolas) de língua, usando } \\
\text { (apoiando-se, explorando) o nome } \\
\text { (marca) de "Cultura Inglesa", existem } \\
\text { muitas internacionalmente (pelo mundo). }\end{array}$ \\
\hline $\begin{array}{l}{[\ldots] \text { é difícil entrar na coração da alma }} \\
\text { brasileira. }\end{array}$ & $\begin{array}{l}\text { [...] é difícil entrar até o fundo da alma } \\
\text { brasileira (penetrar fundo na alma ou no } \\
\text { coração; entender o que se passa na } \\
\text { alma brasileira). }\end{array}$ \\
\hline $\begin{array}{l}\text { Acho que muitos destes estudantes não } \\
\text { continuam com este curso (de inglês). }\end{array}$ & $\begin{array}{l}\text { Acho que muitos destes estudantes não } \\
\text { continuam (não completam o curso, } \\
\text { não permanecem no curso) com o } \\
\text { curso (de inglês). }\end{array}$ \\
\hline $\begin{array}{l}\text { (o que falta para aperfeiçoarem os cursos de inglês?). } \\
\text { A falta é na área comum, nas ruas. }\end{array}$ & $\begin{array}{l}\text { A falta está no uso comum (diário ou } \\
\text { cotidiano) e nas ruas (fora da } \\
\text { embaixada). }\end{array}$ \\
\hline $\begin{array}{l}\text { As diferenças que têm mais normalmente } \\
\text { na área se propriedade público. }\end{array}$ & $\begin{array}{l}\text { As (maiores) diferenças se encontram } \\
\text { (se concentram, acontecem) mais } \\
\text { normalmente na área da propriedade } \\
\text { pública. }\end{array}$ \\
\hline [...] mas esso coisas o mundo inteiro. & $\begin{array}{l}{[\ldots] \text { mas isso são coisas do (acontece }} \\
\text { no) mundo inteiro. }\end{array}$ \\
\hline Nós não temos isto podido $[. .]$. & $\begin{array}{l}\text { Nós (ainda) não pudemos (resolver) } \\
\text { isso [...] }\end{array}$ \\
\hline
\end{tabular}




\begin{tabular}{|c|c|}
\hline & $\begin{array}{l}\text { ou } \\
\text { Nós (ainda) não conseguimos isso [...] }\end{array}$ \\
\hline$[\ldots]$ interces [...] esta área [...] & [...] para interceder nessa área. \\
\hline [...] para alcançar o Distrito Federal [...] & $\begin{array}{l}{[\ldots] \text { para interceder (chegar até) junto }} \\
\text { ao Distrito Federal [...] }\end{array}$ \\
\hline $\begin{array}{l}\text { (permissão) de ter as coisas da } \\
\text { alfândega. }\end{array}$ & $\begin{array}{l}\text { (permissão) para obter (conseguir) as } \\
\text { coisas da alfândega. }\end{array}$ \\
\hline $\begin{array}{l}{[\ldots] \text { essas três línguas têm um número }} \\
\text { conexões }[\ldots]\end{array}$ & $\begin{array}{l}{[\ldots] \text { essas três línguas têm (permitem, }} \\
\text { admitem) um número de conexões } \\
\text { (ligações, junções) [...] }\end{array}$ \\
\hline $\begin{array}{l}{[\ldots . .] \text { os funcionários de Consulado }} \\
\text { ajudam com o residência. }\end{array}$ & $\begin{array}{l}\text { [...] os funcionários do Consulado nos } \\
\text { ajudam a encontrar uma residência. }\end{array}$ \\
\hline Eu vou viver em São Paulo até três anos. & $\begin{array}{l}\text { Eu vou ficar (morar) em São Paulo por } \\
\text { três anos. }\end{array}$ \\
\hline [...] e derrepentemente tudo difícil. & [...] e de repente tudo fica difícil. \\
\hline $\begin{array}{l}\text { Então renovar esta burocracia para } \\
\text { seletar } \\
\text { Brasil. }\end{array}$ & $\begin{array}{l}\text { Então aperfeiçoar esta burocracia para } \\
\text { facilitar (melhorar) a adaptação de } \\
\text { estrangeiros no Brasil. }\end{array}$ \\
\hline $\begin{array}{l}\text { Os homens de negócio estrangeiro } \\
\text { passam muito tempo achando uma casa } \\
{[\ldots]}\end{array}$ & $\begin{array}{l}\text { Os estrangeiros, homens de negócio, } \\
\text { passam muito tempo procurando (para } \\
\text { achar) uma casa }[\ldots]\end{array}$ \\
\hline $\begin{array}{l}{[\ldots] \text { o sucesso aulas de inglês }[\ldots] \text { para }} \\
\text { encontratooutros alunos }[\ldots]\end{array}$ & $\begin{array}{l}{[\ldots] \text { o sucesso das aulas de inglês para }} \\
\text { encontrar (atrair, interessar) outros } \\
\text { alunos [...] }\end{array}$ \\
\hline Tem muito que para gostar & Tem muita coisa para se apreciar. \\
\hline $\begin{array}{l}\text { Eu estou picando/aplicando os projetos } \\
\text { das Artes agora. }\end{array}$ & $\begin{array}{l}\text { Eu estou implementandoprojetos de } \\
\text { Artes agora. }\end{array}$ \\
\hline $\begin{array}{l}{[\ldots] \text { mas eu volto para a Inglaterra duas }} \\
\text { vezes para o ano; eu levo chá inglês, } \\
\text { com certeza. }\end{array}$ & $\begin{array}{l}{[\ldots] \text { mas eu vou para a Inglaterra duas }} \\
\text { vezes por ano e eu trago chá inglês, } \\
\text { com certeza. }\end{array}$ \\
\hline $\begin{array}{l}\text { Eu conheço o movimento dos sem-terras } \\
\text { tem problemas com certeza. }\end{array}$ & $\begin{array}{l}\text { Eu sei que o movimento dos sem-terra } \\
\text { tem (traz, cria, provoca) problemas } \\
\text { com certeza. }\end{array}$ \\
\hline $\begin{array}{l}\text { A menina do supermercado não entende } \\
\text { eu sou inglesa. }\end{array}$ & $\begin{array}{l}\text { A menina do supermercado não } \\
\text { percebeu que eu sou inglesa. }\end{array}$ \\
\hline $\begin{array}{l}\text { Meu VIP foi muito atrasado: ele perdió os } \\
{[\ldots] \text { as malas. }}\end{array}$ & $\begin{array}{l}\text { Meu VIP se atrasou muito (estava } \\
\text { muito atrasado): ele tinha perdido as } \\
\text { malas. }\end{array}$ \\
\hline $\begin{array}{l}\text { Nós nunca procurar (a bagagem) }[\ldots] \\
\text { never found. }\end{array}$ & $\begin{array}{l}\text { Nós nunca achamos (a bagagem } \\
\text { perdida) [...] nunca foi achada } \\
\text { (encontrada, localizada). }\end{array}$ \\
\hline
\end{tabular}




\begin{tabular}{|c|c|}
\hline $\begin{array}{l}{[\ldots] \text { Varig - a linha do avião pegou }} \\
\text { bastante dollars para o VIP. }\end{array}$ & $\begin{array}{l}{[\ldots] \text { a Varig - a companhia de aviação }} \\
\text { pagou (reembolsou) muitos dólares } \\
\text { para o VIP. }\end{array}$ \\
\hline $\begin{array}{l}\text { Eu falei com o professor: hoje eu acho } \\
\text { que nós vamos falar com o vocabulário } \\
\text { do aeroporto. }\end{array}$ & $\begin{array}{l}\text { Eu sugeria ao professor: hoje eu quero } \\
\text { aprender (usar, trabalhar com) } 0 \\
\text { vocabulário do aeroporto. }\end{array}$ \\
\hline $\begin{array}{l}\text { Eu acho que agora eu deve dar os aulas } \\
\text { pra você }[\ldots]\end{array}$ & $\begin{array}{l}\text { Eu julgo que agora eu deva dar aulas } \\
\text { para você }[\ldots]\end{array}$ \\
\hline Não é como os franceses $[\ldots]$ & (Eles) não são como os franceses [...] \\
\hline $\begin{array}{l}{[\ldots] \text { os brasileiros ajudam, mas a maioria }} \\
\text { dos estrangeiros uma dividio }[\ldots]\end{array}$ & $\begin{array}{l}{[\ldots] \text { os brasileiros ajudam, pois a }} \\
\text { maioria dos estrangeiros usa } \\
\text { (apresenta) uma mistura (na fala) }[. . .]\end{array}$ \\
\hline $\begin{array}{l}{[\ldots] \text { - uma conversa pouco estranha, }} \\
\text { mas usando as duas línguas }[\ldots]\end{array}$ & $\begin{array}{l}{[\ldots] \text { - fica (torna- se }{ }^{*} \text { ) uma conversa um }} \\
\text { pouco estranha, pois estão usando as } \\
\text { duas línguas }[\ldots]\end{array}$ \\
\hline $\begin{array}{l}\text { Mesmo que português é uma língua tan } \\
\text { lógica. }\end{array}$ & $\begin{array}{l}\text { Mesmo que o português seja uma } \\
\text { língua tão lógica. }\end{array}$ \\
\hline $\begin{array}{l}{[\ldots] \text { a gramática é difícil - ter mais tipos }} \\
\text { de presente, futuro [...] mas eu pego. }\end{array}$ & $\begin{array}{l}{[\ldots] \text { a gramática é difícil - tem mais }} \\
\text { tipos de presente, futuro [...] mas eu } \\
\text { aprendo (assimilo). }\end{array}$ \\
\hline $\begin{array}{l}\text { Eu estou falando com uma pessoa com } \\
\text { certeza não vai estar lá durante } 99 .\end{array}$ & $\begin{array}{l}\text { Eu estou falando com uma pessoa que, } \\
\text { com certeza, não vai continuar } \\
\text { (permanecer) lá (no mesmo cargo) até } \\
99 .\end{array}$ \\
\hline $\begin{array}{l}\text { Não é possível ficar com uma vez até } \\
\text { uma promoção. }\end{array}$ & $\begin{array}{l}\text { Não é possível ficar (permanecer) a } \\
\text { primeira vez no mesmo país até obter } \\
\text { (ganhar) uma promoção. }\end{array}$ \\
\hline $\begin{array}{l}{[\ldots] \text { quando meu marido trabalho em }} \\
\text { Londres, nós tínhamos [...] }\end{array}$ & $\begin{array}{l}{[\ldots] \text { quando meu marido trabalhava em }} \\
\text { Londres, nós tínhamos [...] }\end{array}$ \\
\hline $\begin{array}{l}{[\ldots] \text { uma linha segunda em casa é }} \\
\text { cinqüenta dólares }[\ldots]\end{array}$ & $\begin{array}{l}{[\ldots] \text { uma segunda linha em casa custa }} \\
\text { (vale) cinqüenta dólares. }\end{array}$ \\
\hline $\begin{array}{l}\text { Geralmente eu vi os filmes populares, } \\
\text { mas não é esto verdade. }\end{array}$ & $\begin{array}{l}\text { Algumas vezes eu vi filmes populares, } \\
\text { mas não retratam (correspondem à) a } \\
\text { verdade. }\end{array}$ \\
\hline Nós aprendemos como vivar no Brasil. & Nós aprendemos como viver no Brasil. \\
\hline $\begin{array}{l}{[\ldots] \text { mas dentro o mesmo prédio a erma }} \\
\text { da esposa }[\ldots]\end{array}$ & $\begin{array}{l}{[\ldots] \text { mas no mesmo prédio mora a irmã }} \\
\text { da esposa }[\ldots]\end{array}$ \\
\hline $\begin{array}{l}\text { [...] depois do jantar, a família, e erma } \\
\text { fica com televisão, coma novela das oito. }\end{array}$ & $\begin{array}{l}\text { [...] depois do jantar, a família toda e a } \\
\text { irmã (inclusive a irmã) ficavam } \\
\text { assistindo à televisão, à novela das } \\
\text { oito. }\end{array}$ \\
\hline Uma vizinha também [...] & Uma vizinha também participava (fazia \\
\hline
\end{tabular}




\begin{tabular}{|c|c|}
\hline & parte) $[\ldots]$ \\
\hline $\begin{array}{l}{[\ldots] \text { porque eu preenche meu cheque }} \\
\text { errado. }\end{array}$ & $\begin{array}{l}{[\ldots] \text { porque eu preenchi meu cheque }} \\
\text { errado. }\end{array}$ \\
\hline$[\ldots]$ mas você precisa continuar $[\ldots]$ & $\begin{array}{l}{[\ldots] \text { mas a gente precisa entender }} \\
\text { (aceitar, relevar), já que temos de } \\
\text { continuar aqui. }\end{array}$ \\
\hline $\begin{array}{l}\text { Eu não saber contar o motorista do táxi } \\
\text { meu endereço. }\end{array}$ & $\begin{array}{l}\text { Eu não soube dizer (informar) ao } \\
\text { motorista do táxi o meu endereço. }\end{array}$ \\
\hline $\begin{array}{l}\text { (ele perdió as malas); este uma grande } \\
\text { problema. }\end{array}$ & $\begin{array}{l}\text { (ele perdeu as malas); isto foi uma } \\
\text { problema sério. }\end{array}$ \\
\hline $\begin{array}{l}\text { Felizmente o menino da loja falou um } \\
\text { pouco inglês. }\end{array}$ & $\begin{array}{l}\text { Felizmente o vendedor falava um pouco } \\
\text { de inglês. }\end{array}$ \\
\hline Esta [...] foi a família da professora. & Esta era a família da professora. \\
\hline $\begin{array}{l}{[\ldots] \text { e também ele quis }[\ldots] \text { ensaio }} \\
\text { gramática. }\end{array}$ & $\begin{array}{l}{[\ldots] \text { e também ela queria só (somente) }} \\
\text { treinar (exercitar) gramática. }\end{array}$ \\
\hline $\begin{array}{l}\text { Eu fui [...] "I was very unhappy" o primeiro } \\
\text { ano aqui. }\end{array}$ & $\begin{array}{l}\text { Eu me senti muito infeliz (eu sofri } \\
\text { muito) no primeiro ano aqui. }\end{array}$ \\
\hline $\begin{array}{l}\text { Eu achó que está muito dificíl procurar } \\
\text { uma professor bem de português. }\end{array}$ & $\begin{array}{l}\text { Eu acho que é muito difícil encontrar } \\
\text { um bom professor de português. }\end{array}$ \\
\hline $\begin{array}{l}{[\ldots] \text { eles estam professoras da inglês e }} \\
\text { eles gostaria falar inglês. }\end{array}$ & $\begin{array}{l}{[\ldots] \text { eles são professores de inglês e }} \\
\text { eles gostariam de (querem) praticar } \\
\text { inglês. }\end{array}$ \\
\hline $\begin{array}{l}{[\ldots] \text { eu perdi uma ano porque eu não }} \\
\text { tinha uma sistema. }\end{array}$ & $\begin{array}{l}{[\ldots] \text { eu perdi um ano porque eu não }} \\
\text { recebia (eles não aplicavam) uma } \\
\text { técnica (uma metodologia) adequada de } \\
\text { ensino. }\end{array}$ \\
\hline $\begin{array}{l}\text { Se você não fala português bem, você } \\
\text { não tem autoridade bem. }\end{array}$ & $\begin{array}{l}\text { Se você não fala bem o português, você } \\
\text { não mantém uma boa autoridade. }\end{array}$ \\
\hline $\begin{array}{l}\text { [...] é muito dificíl admitir: você tem um } \\
\text { língua fraca ou você não tem } \\
\text { conhecimento com sua quadra. }\end{array}$ & $\begin{array}{l}\text { [...] é muito difícil admitir (reconhecer) } \\
\text { que você tem dificuldade de expressão } \\
\text { ou que você não tem (não consegue) } \\
\text { boa comunicação com seu quadro (de } \\
\text { funcionários). }\end{array}$ \\
\hline
\end{tabular}

\subsubsection{Dificuldades relativas aos advérbios.}

\begin{tabular}{|l|l|}
\hline \multicolumn{1}{|c|}{ Interlíngua } & Língua 2 \\
\hline Eu prefero muito as montanhas. & Eu prefiro muito mais (bem mais) as \\
\hline
\end{tabular}




\begin{tabular}{|c|c|}
\hline & has. \\
\hline $\begin{array}{l}\text { O fato de que poucos brasileiros conhece } \\
\text { a língua inglês bem. }\end{array}$ & $\begin{array}{l}\text { O fato é que poucos brasileiros } \\
\text { conhecem bema língua inglesa. }\end{array}$ \\
\hline is especificamente & $\begin{array}{l}{[\ldots] \quad \text { muitas }} \\
\text { particularmente entre São Paulo e } \\
\text { Londres. }\end{array}$ \\
\hline $\begin{array}{l}{[\ldots] \text { na área turís }} \\
\text { únicos estam interes } \\
\text { estam ensinando ing }\end{array}$ & $\begin{array}{l}{[\ldots] \text { da área turística, porque estas }} \\
\text { (pessoas) são as únicas que estão } \\
\text { interessadas, e conseqüentemente, } \\
\text { estão ensinando inglês; [...] }\end{array}$ \\
\hline jações $[. .$.$] , têm$ & $\begin{array}{l}\text { Essas escolas de comunicação [...], } \\
\text { existem muitas internacionalmente } \\
\text { (pelo mundo). }\end{array}$ \\
\hline $\begin{array}{l}\text { (O que } \\
\text { A fa }\end{array}$ & $\begin{array}{l}\text { A falta está no uso comum (diário, } \\
\text { cotidiano), fora da embaixada. }\end{array}$ \\
\hline$\underline{\text { almente }}$ & $\begin{array}{l}\text { As diferenças existem mais } \\
\text { especificamente } \\
\text { comumente) na área da }[. . .]\end{array}$ \\
\hline ha pouco mais semelhante & $\begin{array}{l}{[\ldots] \text { um sistema bem (muito) }} \\
\text { semelhante (mais próximo) ao do Brasil. }\end{array}$ \\
\hline voando, conhecendo & $\begin{array}{l}\text { Eu prefiro ficar voando, conhecendo } \\
\text { lugares lá de cima (lá do alto). }\end{array}$ \\
\hline $\begin{array}{l}\text { Isso só acontece em outros países } \\
\text { também. }\end{array}$ & $\begin{array}{l}\text { Isso acontece em outros países } \\
\text { também. } \\
\text { Isso também (igualmente) acontece } \\
\text { em outros países. }\end{array}$ \\
\hline $\begin{array}{l}\text { Poucos brasileiros conhece a Inglaterra } \\
\text { bem. }\end{array}$ & $\begin{array}{l}\text { Poucos brasileiros conhecem bem a } \\
\text { Inglaterra. }\end{array}$ \\
\hline $\begin{array}{l}\text { - um problema, mas justo como os } \\
\text { motoristas de táxi. }\end{array}$ & $\begin{array}{l}\text { (a) - um problema, mas isto acontece } \\
\text { exatamente com os motoristas de táxi. } \\
\text { (b) - um problema, mas (isto) é } \\
\text { exatamente como acontece com os } \\
\text { motoristas de táxi. }\end{array}$ \\
\hline $\begin{array}{l}{[\ldots] \text { no futuro, nós vamos ter um sistema }} \\
\text { pouco mais semelhante como no Brasil. }\end{array}$ & $\begin{array}{l}\text { [...] no futuro, nós vamos ter um sistema } \\
\text { bem semelhante (mais próximo, mais } \\
\text { parecido) ao do Brasil. }\end{array}$ \\
\hline $\begin{array}{l}{[\ldots] \quad \text { com as coisas simples, parece }} \\
\text { simples, }[\ldots]\end{array}$ & $\begin{array}{l}{[\ldots] \text { com coisas simples, aparentemente }} \\
\text { simples, }[\ldots]\end{array}$ \\
\hline Eu prefero o "[...] party", mas agora é & Eu prefiro o "[...] partido", mas hoje em \\
\hline
\end{tabular}




\begin{tabular}{|c|c|}
\hline $\begin{array}{l}\text { muito dificíl porque todos os políticos têm } \\
\text { o Centro, }[. . .]\end{array}$ & $\begin{array}{l}\text { dia isso é muito difícil porque todos os } \\
\text { políticos são de Centro, [...] }\end{array}$ \\
\hline$[\ldots]$ e derrepentemente tudo difícil [...] & [...] e de repente tudo fica difícil. \\
\hline Eu teve Campinas acasomente. & Eu estive em Campinas por acaso. \\
\hline $\begin{array}{l}\text { Não é possível ficar com uma vez aqui } \\
\text { até uma promoção }[\ldots]\end{array}$ & $\begin{array}{l}\text { Não é possível ficar (permanecer) a } \\
\text { primeira vez no mesmo país até obter } \\
\text { (ganhar) uma promoção [...] }\end{array}$ \\
\hline$\frac{\text { Geralmente }}{\text { cidades }[\ldots]}$ eu visitei $[\ldots]$ eu visitou os & Realmente eu visitei as cidades [...] \\
\hline $\begin{array}{l}\text { Eu acho que geralmente não é possível } \\
\text { ficar com uma vez aqui até uma } \\
\text { promoção }[\ldots]\end{array}$ & $\begin{array}{l}\text { Eu acho que na verdade (realmente) } \\
\text { não é possível ficar a primeira vez no } \\
\text { mesmo país até obter uma promoção }\end{array}$ \\
\hline (Gostou de Campos do Jordão?) & \\
\hline Gosto bem - como Inglaterra. & Gostei bastante - é como a Inglaterra. \\
\hline Eu gostei bem ${ }^{*}$ do MIS. & Eu gostei bastante $^{* *}$ do MIS. \\
\hline $\begin{array}{l}{[\ldots] \text { durante o primeiro ano eu tentei bem }} \\
\text { escutar português. }\end{array}$ & $\begin{array}{l}{[\ldots] \text { durante o primeiro ano eu tentei }} \\
\text { bastante }{ }^{* *} \text { ouvir português. }\end{array}$ \\
\hline 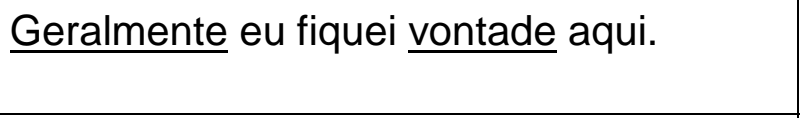 & $\begin{array}{l}\text { Realmente eu fiquei à vontade aqui } \\
\text { (para dizer tudo isso). }\end{array}$ \\
\hline (O que acha dos filmes brasileiros?) & \\
\hline Geralmente eu vi os filmes populares, $[\ldots]$ & $\begin{array}{l}\text { Algumas vezes eu vi filmes populares, } \\
{[\ldots]}\end{array}$ \\
\hline (Sentiu falta de sua alimentação?) & \\
\hline Realmente pequeño. & Realmente um (muito) pouco. \\
\hline $\begin{array}{l}\text { (Voltou a estudar português?) } \\
\text { Ah! Um pequeño } \\
\end{array}$ & Ah! Um pouco. \\
\hline $\begin{array}{l}{[\ldots] \text { a gramática é necessário, mas a }} \\
\text { início o vocabulário é melhor. }\end{array}$ & $\begin{array}{l}{[\ldots] \text { a gramática é necessária, mas no }} \\
\text { início (no começo) o vocabulário é } \\
\text { mais importante. }\end{array}$ \\
\hline $\begin{array}{l}\text { Eu tinha um professora por duas horas } \\
\text { cada semana. }\end{array}$ & $\begin{array}{l}\text { Eu tinha uma professora duas horas } \\
\text { por semana. }\end{array}$ \\
\hline $\begin{array}{l}\text { (é interessante) aprenda uma }[\ldots] \text { a } \\
\text { História do Brasil porque eu conhece } \underline{\text { um }} \\
\text { menor. }\end{array}$ & $\begin{array}{l}\text { (seja necessário) aprender mais sobre a } \\
\text { História do Brasil porque eu conheço } \\
\text { um pouco. }\end{array}$ \\
\hline $\begin{array}{l}\text { Uma sistema bastantíssimo dificíl se } \\
\text { você não tem uma professor bem. }\end{array}$ & $\begin{array}{l}\text { Um sistema bastante (muitíssimo) } \\
\text { difícil se você não tem um bom } \\
\text { professor. }\end{array}$ \\
\hline $\begin{array}{l}\text { Na Inglaterra, exclusivamente, português } \\
\text { não é uma língua onde é fácil encontrar } \\
{[\ldots]}\end{array}$ & $\begin{array}{l}\mathrm{Na} \quad \text { Inglaterra, especificamente, } \\
\text { português não é uma língua fácil de se } \\
\text { encontrar [...] }\end{array}$ \\
\hline
\end{tabular}




\begin{tabular}{|c|c|}
\hline $\begin{array}{l}{[\ldots] \text { mas, realmente }[\ldots] \text { geralmente tudos }} \\
\text { está tranqüilo }[\ldots]\end{array}$ & $\begin{array}{l}{[\ldots] \text { mas realmente }[\ldots] \text { tudo está }} \\
\text { tranqüilo (resolvido) }[. . .]\end{array}$ \\
\hline $\begin{array}{l}{[\ldots] \text { ele trabalha com teatro por quatro e }} \\
\text { seis meses cada ano. }\end{array}$ & $\begin{array}{l}{[\ldots] \text { ele trabalha com teatro de quatro a }} \\
\text { seis meses por ano. }\end{array}$ \\
\hline Geralmente eu fiquei vontade aqui. & Realmente eu fiquei à vontade aqui. \\
\hline $\begin{array}{l}\text { - por favor, a rua Conselheiro Brotero [...] } \\
\text { Higienópolis. Quem? }\end{array}$ & $\begin{array}{l}\text { - por favor, a rua Conselheiro Brotero } \\
\text { em Higienópolis. Onde? }\end{array}$ \\
\hline $\begin{array}{l}\text { Eu acho que de novo eu vou fazer, eu } \\
\text { deve fazer uma procuração muitos } \\
\text { detalhes, com muitos detalhes } \\
\text { professor. }\end{array}$ & $\begin{array}{l}\text { Eu acho que novamente (mais uma } \\
\text { vez) eu vou fazer, eu devo fazer uma } \\
\text { busca bem (muito) detalhada (com } \\
\text { muito rigor) de (um bom) professor. }\end{array}$ \\
\hline Eu não estou muito ruim da línguas. & $\begin{array}{l}\text { Eu não estou muito mal na língua (em } \\
\text { português). }\end{array}$ \\
\hline Eles falam português muito bom. & Eles falam português muito bem. \\
\hline (Falando sobre o preço de um reparo hidráulico.) & \\
\hline $\begin{array}{l}\text { Esse um desastre: } \\
\text { exageradamente. }\end{array}$ & $\begin{array}{l}\text { Foi um horror: paguei muito caro (um } \\
\text { exagero). }\end{array}$ \\
\hline
\end{tabular}

\subsubsection{Dificuldades relativas às construções (preposição, conjunção e outros elementos de ligação).}

\begin{tabular}{|c|c|}
\hline gua & Língua 2 \\
\hline Dá para voar em todo o parte do $r$ & $\begin{array}{l}\text { Dá para voar por toda a parte do } \\
\text { mundo. }\end{array}$ \\
\hline $\begin{array}{l}\text { O fato de que poucos brasileiros conhece } \\
\text { a língua inglês bem. }\end{array}$ & $\begin{array}{l}\text { O fato é que poucos brasileiros } \\
\text { conhecem bem a língua inglesa. }\end{array}$ \\
\hline $\begin{array}{l}\text { Acho que São Paulo brasileiros } \\
\text { completamente diferente. }\end{array}$ & $\begin{array}{l}\text { Acho que em São Paulo os brasileiros } \\
\text { são completamente diferentes. }\end{array}$ \\
\hline Eu não estou especialista de líng & lista em líng \\
\hline $\begin{array}{l}{[\ldots] \text { muitas semelhanças especificamente }} \\
\text { em São Paulo e Londres. }\end{array}$ & $\begin{array}{l}{[\ldots] \text { muitas semelhanças }} \\
\text { particularmente entre São Paulo e } \\
\text { Londres. }\end{array}$ \\
\hline aproveita & Nós gostamos de aproveitar os pa \\
\hline $\begin{array}{l}{[\ldots] \text { com as coisas simples, parece }} \\
\text { simples, }[\ldots]\end{array}$ & $\begin{array}{l}{[\ldots] \text { com coisas simples, que parecem }} \\
\text { simples, }[\ldots]\end{array}$ \\
\hline $\begin{array}{l}\text { Depois do curso, têm um certificado, } \\
\text { esquece tudo. }\end{array}$ & $\begin{array}{l}\text { Depois do curso, obtêm um certificado, } \\
\text { mas (e logo depois) esquecem tudo. }\end{array}$ \\
\hline $\begin{array}{l}{[\ldots] \text { na área turístico, porque estes }} \\
\text { únicos estam interessados, normalmente }\end{array}$ & $\begin{array}{l}{[\ldots] \text { da área turística, porque estas }} \\
\text { (pessoas) são as únicas que estão }\end{array}$ \\
\hline
\end{tabular}




\begin{tabular}{|c|c|}
\hline estam ensinando inglês. & $\begin{array}{l}\text { interessadas, e, conseqüentemente, } \\
\text { estão ensinando inglês. }\end{array}$ \\
\hline O problema é na aula de alunos. & O problema está na aula com alunos. \\
\hline $\begin{array}{l}\text { Mesmo que português é uma língua tan } \\
\text { lógica }[. . .]\end{array}$ & $\begin{array}{l}\text { Mesmo que português seja uma língua } \\
\text { tão lógica [...] }\end{array}$ \\
\hline [...] um pouco de modo, este [...] verbos. & $\begin{array}{l}{[\ldots] \text { um pouco está no ensino dos }} \\
\text { modos, este (problema que ocorre com } \\
\text { as formas variadas dos verbos). }\end{array}$ \\
\hline $\begin{array}{l}\text { Gentes como Estado de São Paulo não } \\
\text { fizi nada para nós. }\end{array}$ & $\begin{array}{l}\text { As pessoas do Estado de São Paulo } \\
\text { não fizeram nada para nós. }\end{array}$ \\
\hline [...] mas esso é uma parte de Consulado. & $\begin{array}{l}{[\ldots] \text { mas isso é um problema (uma }} \\
\text { responsabilidade) do Consulado. }\end{array}$ \\
\hline $\begin{array}{l}{[\ldots] \text { trabalho sem disturbance, sem }} \\
\text { dificuldades, juntos com viver sem } \\
\text { dificuldades. }\end{array}$ & $\begin{array}{l}\text { [...] trabalho sem perturbação, sem } \\
\text { dificuldades, assim como (como } \\
\text { também; além de) viver sem } \\
\text { problemas. }\end{array}$ \\
\hline $\begin{array}{l}\text { O Distrito Federal dificulta nosso trabalho } \\
\text { o coisas da alfândega. }\end{array}$ & $\begin{array}{l}\text { O Distrito Federal dificulta nosso } \\
\text { trabalho com os serviços da alfândega. }\end{array}$ \\
\hline $\begin{array}{l}\text { Este coisa de Ensino Inglês no Brasil é } \\
\text { interessante. }\end{array}$ & $\begin{array}{l}\text { O problema (a questão) do Ensino de } \\
\text { Inglês no Brasil é interessante. }\end{array}$ \\
\hline $\begin{array}{l}\text { [...] para fazer mais ligações como fazem } \\
\text { outros partes, incluindo a Inglaterra. }\end{array}$ & $\begin{array}{l}{[\ldots] \text { para fazer mais contatos como }} \\
\text { fazem outras partes do mundo (outros } \\
\text { países), incluindo a Inglaterra. }\end{array}$ \\
\hline [...] em tudos detais na área turístico. & $\begin{array}{l}{[\ldots] \text { em todos os detalhes (pormenores, }} \\
\text { situações) da área turística. }\end{array}$ \\
\hline Eu senti uma falta dos coisas de comida. & $\begin{array}{l}\begin{array}{l}\text { Senti falta das coisas de comer } \\
\text { (comestíveis). }\end{array}\end{array}$ \\
\hline [...] falta de pequenas coisinhas. & [...] falta de pequenas coisas. \\
\hline Para mim acho que muitos coisas falta. & Acho que faltam muitas coisas. \\
\hline $\begin{array}{l}\text { As diferenças que têm mais normalmente } \\
\text { na área de propriedade público. }\end{array}$ & $\begin{array}{l}\text { As diferenças se encontram mais } \\
\text { normalmente na área da propriedade } \\
\text { pública. }\end{array}$ \\
\hline [...] os qualidade de transporte coletivo. & [...] a qualidade do transporte coletivo. \\
\hline [...] os ônibus infelizmente ruins. & [...] os ônibus infelizmente são ruins. \\
\hline $\begin{array}{l}{[\ldots] \text { para as crianças (inglesas) é pouco }} \\
{[\ldots] \text { é difícil entender a criança como as }} \\
\text { crianças brasileiros. }\end{array}$ & $\begin{array}{l}{[\ldots] \text { para as crianças (inglesas) é um }} \\
\text { pouco difícil entender uma criança como } \\
\text { a brasileira (entender as crianças } \\
\text { brasileiras). }\end{array}$ \\
\hline [...] mas esso coisas o mundo inteiro. & $\begin{array}{l}{[\ldots] \text { mas isso são coisas do mundo }} \\
\text { inteiro. }\end{array}$ \\
\hline [...] ambas no Brasil estes estra & [...] (acontece) não só no Brasil como \\
\hline
\end{tabular}




\begin{tabular}{|c|c|}
\hline também [...] & no país desses estrangeiros também [...] \\
\hline $\begin{array}{l}\text { A minha vida aqui no Consulado uma ilha } \\
\text { de Inglês. }\end{array}$ & $\begin{array}{l}\text { A minha vida aqui no Consulado é uma } \\
\text { ilha (cheia) de Ingleses (isolada de } \\
\text { outros lugares). }\end{array}$ \\
\hline $\begin{array}{l}\text { Fernando Henrique parece como um } \\
\text { homem honesto. }\end{array}$ & $\begin{array}{l}\text { Fernando Henrique parece (ser) um } \\
\text { homem honesto. }\end{array}$ \\
\hline $\begin{array}{l}{[\ldots] \text { um sistema de governo muito }} \\
\text { complexo - junto com o nível federal, } \\
\text { estadual, municipal. }\end{array}$ & $\begin{array}{l}{[\ldots] \text { um sistema de governo muito }} \\
\text { complexo unindo (que uni) os níveis } \\
\text { federal, estadual e municipal (ou o nível } \\
\text { federal, estadual, municipal). }\end{array}$ \\
\hline $\begin{array}{l}\text { Existem políticos demais, por exemplo, } \\
\text { Câmara dos Deputados, os Congressos, } \\
\text { a gente [...] }\end{array}$ & $\begin{array}{l}\text { Existem políticos demais se somarmos a } \\
\text { Câmara dos Deputados, os Congressos } \\
\text { e a gente [...] }\end{array}$ \\
\hline $\begin{array}{l}{[\ldots], \text { os Congressos, a gente com todos }} \\
\text { os vinte e sete Estados. }\end{array}$ & $\begin{array}{l}{[\ldots], \text { os Congressos e a gente (as }} \\
\text { pessoas, os representantes) de todos os } \\
\text { vinte e sete Estados. }\end{array}$ \\
\hline $\begin{array}{l}\text { Nós não temos isto podido interces }[. . .] \\
\text { nesta área. }\end{array}$ & $\begin{array}{l}\text { Nós (ainda) não pudemos (resolver) isto } \\
\text { [...] } \\
\text { ou } \\
\text { Nós (ainda) não conseguimos interceder } \\
\text { nessa área. }\end{array}$ \\
\hline $\begin{array}{l}{[\ldots] \text { nós temos poder para alcançar o }} \\
\text { Distrito Federal liberar nossos bens. }\end{array}$ & $\begin{array}{l}{[\ldots] \text { nós temos poder para interceder }} \\
\text { junto ao Distrito Federal a fim de (para) } \\
\text { liberar nossos bens. }\end{array}$ \\
\hline $\begin{array}{l}\text { É muito mais difícil do que nossos na } \\
\text { Inglaterra. }\end{array}$ & 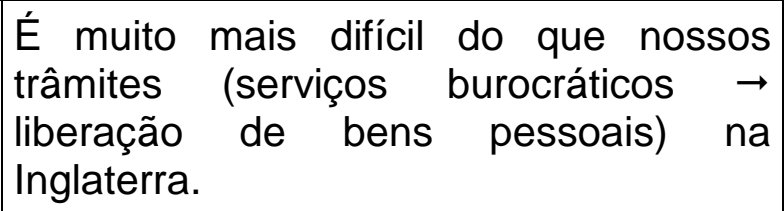 \\
\hline $\begin{array}{l}{[\ldots .] \text { mas com meu trabalho só posso ficar }} \\
\text { dois anos. }\end{array}$ & $\begin{array}{l}{[\ldots] \text { mas por causa do meu trabalho só }} \\
\text { posso ficar dois anos. }\end{array}$ \\
\hline $\begin{array}{l}\text { Eu gosto de se meter num país, comer a } \\
\text { comida deles, se adaptar. }\end{array}$ & $\begin{array}{l}\text { Eu gosto de me enfiar (me alojar) num } \\
\text { país, comer sua comida, adaptar-me. }\end{array}$ \\
\hline $\begin{array}{l}\text { (Demora muito?) [...] toda essa coisa de } \\
\text { burocracia para obter permissão de } \\
\text { dirigir, de pilotar, de ter as coisas da } \\
\text { alfândega. }\end{array}$ & $\begin{array}{l}{[\ldots] \text { todos esses trâmites burocráticos }} \\
\text { para obter permissão para dirigir, para } \\
\text { pilotar, para obter (conseguir) as coisas } \\
\text { da alfândega. }\end{array}$ \\
\hline $\begin{array}{l}\text { Só que eu acho São Paulo é muito } \\
\text { diferente. }\end{array}$ & $\begin{array}{l}\text { Só que eu acho que São Paulo é muito } \\
\text { diferente. }\end{array}$ \\
\hline Moro São Paulo quinze meses. & Moro em São Paulo há quinze meses. \\
\hline $\begin{array}{l}\text { Essas três línguas têm um número } \\
\text { conexões. }\end{array}$ & $\begin{array}{l}\text { Essas três línguas têm um número de } \\
\text { conexões (de ligações, de junções). }\end{array}$ \\
\hline os funcionários de Consulado & [...] os funcionários do Consulado nos \\
\hline
\end{tabular}




\begin{tabular}{|c|c|}
\hline ajudam com o residência. & ajudam a encontrar uma residência. \\
\hline [...] todos na cidade, a prefeitura. & $\begin{array}{l}{[\ldots] \text { todos na (da) cidade através da }} \\
\text { prefeitura. }\end{array}$ \\
\hline Eu vou viver em São Paulo até três anos. & $\begin{array}{l}\text { Eu vou ficar (morar) em São Paulo por } \\
\text { três anos. }\end{array}$ \\
\hline $\begin{array}{l}{[\ldots] \text { o comercial de estrangeiros assuntos }} \\
\text { roubos. }\end{array}$ & $\begin{array}{l}{[\ldots] \text { o comercial de estrangeiros sobre }} \\
\text { assuntos de roubos. }\end{array}$ \\
\hline [...] só eu estivesse não cassado. & $\begin{array}{l}\text { [...] (Faria isso) só se eu não estivesse } \\
\text { casado. }\end{array}$ \\
\hline $\begin{array}{l}{[\ldots] \text { esse }[\ldots] \text { lindas mulheres }[\ldots] \text { muito }} \\
\text { fantástico. }\end{array}$ & $\begin{array}{l}\text { (Tudo) isso e também (além de) lindas } \\
\text { mulheres, tudo é muito fantástico. }\end{array}$ \\
\hline $\begin{array}{l}\text { O entusiasmo dos brasileiros conhece } \\
\text { outros países. }\end{array}$ & $\begin{array}{l}\text { O entusiasmo dos brasileiros em } \\
\text { conhecer outros países. }\end{array}$ \\
\hline [...] transtornos do trânsito. & $\begin{array}{l}\text { [...] transtornos de trânsito (ou no } \\
\text { trânsito). }\end{array}$ \\
\hline $\begin{array}{l}\text { É preciso fazer uma melhoramento } \\
\text { dentro desses áreas do público. }\end{array}$ & $\begin{array}{l}\text { É preciso fazer um melhoramento } \\
\text { (reforma, mudança) nessas áreas } \\
\text { públicas. }\end{array}$ \\
\hline Esse coisas de crianças. & Essas coisas para crianças [...] \\
\hline $\begin{array}{l}\text { Nosso sistema foi mais simples como um } \\
\text { governo nacional e um governos } \\
\text { municipal. }\end{array}$ & $\begin{array}{l}\text { Nosso sistema é mais simples com um } \\
\text { governo nacional e um municipal. }\end{array}$ \\
\hline $\begin{array}{l}\text { O político de nosso governo e a muitos } \\
\text { partes governo da Escócia, o governo do } \\
\text { país de Gales, grande parte da Inglaterra. }\end{array}$ & $\begin{array}{l}\text { A política de nosso governo e de muitos } \\
\text { setores (divisões) do governo da } \\
\text { Escócia, do governo do país de Gales, } \\
\text { de grande parte da Inglaterra. }\end{array}$ \\
\hline $\begin{array}{l}{[\ldots] \text { um sistema pouco mais semelhante }} \\
\text { como no Brasil. }\end{array}$ & $\begin{array}{l}{[\ldots] \text { um sistema bem semelhante (mais }} \\
\text { próximo) ao do Brasil. }\end{array}$ \\
\hline $\begin{array}{l}\text { [...] possivelmente porque até agora não } \\
\text { existe um médio, por exemplo, a coisas } \\
\text { internacionais. }\end{array}$ & $\begin{array}{l}\text { [...] possivelmente porque até agora } \\
\text { não existe (exista) um meio (de } \\
\text { atendimento, de aplicação), por } \\
\text { exemplo, em coisas internacionais. }\end{array}$ \\
\hline $\begin{array}{l}\text { - um problema, mas justo como os } \\
\text { motoristas de táxi [...] }\end{array}$ & $\begin{array}{l}\text { - um problema, mas isto acontece } \\
\text { exatamente com os motoristas de táxi } \\
{[\ldots]} \\
\text { Parafraseando: } \\
\text { - um problema, mas (isto) é exatamente } \\
\text { como acontece com os motoristas de } \\
\text { táxi [...] }\end{array}$ \\
\hline $\begin{array}{l}\text { Os pais dos crianças brasileiros lá são de } \\
\text { classe alta. }\end{array}$ & $\begin{array}{l}\text { Os pais das crianças brasileiras de lá } \\
\text { são de classe alta. }\end{array}$ \\
\hline
\end{tabular}




\begin{tabular}{|c|c|}
\hline $\begin{array}{l}\text { Os homens de negócio estrangeiro } \\
\text { passam muito tempo achando uma casa } \\
{[\ldots]}\end{array}$ & $\begin{array}{l}\text { Os estrangeiros, homens de negócio, } \\
\text { passam muito tempo procurando }[. . .]\end{array}$ \\
\hline $\begin{array}{l}{[\ldots] \text { eu acho }[. . .] \text { procura trabalho nas }} \\
\text { outros países. }\end{array}$ & $\begin{array}{l}{[\ldots] \text { eu acho que é por isso que (o }} \\
\text { estrangeiro) procura trabalho nos outros } \\
\text { países. }\end{array}$ \\
\hline $\begin{array}{l}\text { Todo mundo sabe da burocracia Brasil é } \\
\text { uma lião. }\end{array}$ & $\begin{array}{l}\text { Todo mundo sabe que a burocracia no } \\
\text { Brasil é um leão. }\end{array}$ \\
\hline $\begin{array}{l}{[\ldots] \text { porque o Cultura Inglesa, outras }} \\
\text { escolas de língua, são cheio dos } \\
\text { estudantes. }\end{array}$ & $\begin{array}{l}\text { [...] porque a Cultura Inglesa ou outras } \\
\text { escolas de língua (inglesa) estão cheias } \\
\text { de estudantes. }\end{array}$ \\
\hline $\begin{array}{l}{[\ldots] \text { curiosamente os bancos, esses }[\ldots]} \\
\text { coisas de seguro, outro tanto }[\ldots] \\
\text { conhecimento de Inglês. }\end{array}$ & $\begin{array}{l}\text { [...] curiosamente os bancos, com essas } \\
\text { coisas (assuntos) de seguro, e outras } \\
\text { coisas semelhantes exigem } \\
\text { conhecimento de Inglês. }\end{array}$ \\
\hline $\begin{array}{l}{[\ldots] \text { o sucesso aulas de Inglês }[\ldots] \text { para }} \\
\text { encontrato outros alunos }[\ldots]\end{array}$ & $\begin{array}{l}\text { [...] o sucesso das aulas de Inglês para } \\
\text { se conseguir (obter) inscrição de outros } \\
\text { alunos (para atrair, encontrar outros } \\
\text { alunos). }\end{array}$ \\
\hline Eu estudei a português Londres. & Eu estudei português em Londres. \\
\hline $\begin{array}{l}\text { Eu parei de estudar quando passa uma } \\
\text { prova, }[\ldots]\end{array}$ & $\begin{array}{l}\text { Eu parei de estudar quando ela passou } \\
\text { uma prova, }[\ldots]\end{array}$ \\
\hline $\begin{array}{l}\text { [...] quando passa uma prova, uma coisa } \\
\text { de nível intermediário. }\end{array}$ & $\begin{array}{l}{[\ldots] \text { quando eles deram uma prova, uma }} \\
\text { prova de nível intermediário. }\end{array}$ \\
\hline $\begin{array}{l}\text { Nós não temos isto podido interces [...] } \\
\text { nesta área. }\end{array}$ & $\begin{array}{l}\text { Nós não temos podido interceder nisto } \\
{[\ldots] \text { nesta área. }}\end{array}$ \\
\hline $\begin{array}{l}{[\ldots] \text { esse coisa de todas palavras }} \\
\text { português têm muito diferente sentido. }\end{array}$ & $\begin{array}{l}\text { [...] essa coisa de todas as palavras do } \\
\text { português terem sentidos muito } \\
\text { diferentes. }\end{array}$ \\
\hline Tem muito que para gostar. & Tem muita coisa para se apreciar. \\
\hline Pode ser um gosto muito bom. & $\begin{array}{l}\text { Pode ser (uma coisa) muito agradável } \\
\text { (gostosa). }\end{array}$ \\
\hline Tem que manter um sentido de humor. & enso de humor. \\
\hline Deixe-me ver, a pessoa não está; [...] & Deixe-me ver, a pessoa não está; [...] \\
\hline [...] eu não espero o projeto vai mudar & $\begin{array}{l}\text { 1- [...] eu não acho (espero) que o } \\
\text { projeto mude (opinião) } \\
\text { 2- [...] eu espero (I wish) que o projeto } \\
\text { não mude (desejo) }\end{array}$ \\
\hline $\begin{array}{l}\text { Mesmo que português é uma língua tan } \\
\text { lógica }[. . .]\end{array}$ & $\begin{array}{l}\text { Mesmo que o português seja uma } \\
\text { língua tão lógica }[. . .]\end{array}$ \\
\hline
\end{tabular}




\begin{tabular}{|c|c|}
\hline [...] mas talvez, nós não temos certeza & $\begin{array}{l}{[\ldots] \text { talvez (isso aconteça) mas nós não }} \\
\text { temos certeza. }\end{array}$ \\
\hline $\begin{array}{l}\text { Eu tenho }[. . .] \text { e estou nervoso sobre o } \\
\text { programa. }\end{array}$ & $\begin{array}{l}\text { Eu estou nervosa (preocupada com) por } \\
\text { causa do programa. }\end{array}$ \\
\hline $\begin{array}{l}{[\ldots] \text { eu acho que o causa esta contratos, }} \\
\text { mas realmente [...] geralmente tudos } \\
\text { está tranqüilo. }\end{array}$ & $\begin{array}{l}\text { Quanto a estes contratos realmente } \\
\text { tudo está tranqüilo (decidido, resolvido, } \\
\text { sem problemas). }\end{array}$ \\
\hline $\begin{array}{l}\text { Ele gosta do sol, do ambiente, o litoral } \\
{[\ldots]}\end{array}$ & Ele gosta do sol, do amb \\
\hline $\begin{array}{l}{[\ldots] \text { mas eu volto para a Inglaterra duas }} \\
\text { vezes para o ano, }[\ldots]\end{array}$ & $\begin{array}{l}{[\ldots] \text { mas eu volto (vou) para a Inglaterra }} \\
\text { duas vezes por ano. }\end{array}$ \\
\hline $\begin{array}{l}\text { O Conselho está uma Instituição com um } \\
\text { cultura mais formal. }\end{array}$ & $\begin{array}{l}\text { O Conselho é uma Instituição com uma } \\
\text { postura (que apresenta uma postura) } \\
\text { mais formal (do que a média). }\end{array}$ \\
\hline $\begin{array}{l}m[\ldots] \text { nós preferimos } \\
\text { l. }\end{array}$ & $\begin{array}{l}\text { Nós do Conselho preferimos ter } \\
\text { contratos por escrito. }\end{array}$ \\
\hline $\begin{array}{l}\text { Eu conheço o movimento dos sem-terras } \\
\text { tem problemas com certeza, tem um } \\
\text { mistura da pessoas. }\end{array}$ & $\begin{array}{l}\text { Eu sei que o movimento dos sem-terra } \\
\text { tem problemas com certeza porque tem } \\
\text { (por causa da) mistura de pessoas. }\end{array}$ \\
\hline $\begin{array}{l}\text { A menina do supermercado não entende } \\
\text { eu sou Inglesa. }\end{array}$ & $\begin{array}{l}\text { A menina do supermercado não } \\
\text { percebeu que eu sou Inglesa. }\end{array}$ \\
\hline $\begin{array}{l}\text { arido e eu fomos pra Rio por três } \\
\text { s. }\end{array}$ & $\begin{array}{l}\text { para o Rio (e lá } \\
\text { is. }\end{array}$ \\
\hline Nós nãc & $\begin{array}{l}\text { Nós não conhecía } \\
\text { (conhecíamos pouc }\end{array}$ \\
\hline $\begin{array}{l}\text { Eu falei com o professor: hoje eu acho } \\
\text { que nós vamos falar com }{ }^{*} \text { o vocabulário } \\
\text { do aeroporto, o vocabulário dos carros. }\end{array}$ & $\begin{array}{l}\text { Eu sugeria ao professor: hoje eu quero } \\
\text { aprender o vocabulário do aeroporto; } \\
\text { hoje, o vocabulário de carros (eu decidia } \\
\text { qual o vocabulário). }\end{array}$ \\
\hline $\begin{array}{l}\text { Eu acho que agora eu deve dar os aulas } \\
\text { pra você porque meu experiência } \\
\text { aprendendo Português. }\end{array}$ & $\begin{array}{l}\text { Eu julgo que agora eu (já) posso (possa) } \\
\text { dar aulas para você, pela minha } \\
\text { experiência em aprender Português. }\end{array}$ \\
\hline Eu precisei ter uma autoridade. & $\begin{array}{l}\text { Eu precisava manter minha autoridade } \\
\text { (me impor). }\end{array}$ \\
\hline $\begin{array}{l}\text { É suficiente para comunicar esses } \\
\text { pessoas área comercial. }\end{array}$ & $\begin{array}{l}\text { É suficiente para me comunicar com } \\
\text { pessoas da área comercial. }\end{array}$ \\
\hline $\begin{array}{l}\text { É uma aula de português para ajuda o } \\
\text { trabalho }[. . .]\end{array}$ & $\begin{array}{l}\text { É uma aula de português para me } \\
\text { ajudar no trabalho. }\end{array}$ \\
\hline $\begin{array}{l}\text { Então na area de bares, restaurantes } \\
\text { encontra outras pessoas fora da área do } \\
\text { trabalho }[\ldots]\end{array}$ & $\begin{array}{l}\text { Então nos bares e restaurantes quando } \\
\text { eu encontro outras pessoas fora da área } \\
\text { do trabalho }[. . .]\end{array}$ \\
\hline
\end{tabular}




\begin{tabular}{|c|c|}
\hline $\begin{array}{l}{[\ldots] \text { na área de bares, restaurantes }[\ldots],} \\
\text { eu não entendo estas palavras. }\end{array}$ & $\begin{array}{l}{[\ldots] \text { na área de bares e restaurantes já }} \\
\text { vou dizendo: eu não entendo essas } \\
\text { palavras. }\end{array}$ \\
\hline $\begin{array}{l}\text { Português não é uma língua onde é fácil } \\
\text { encontrar aulas. }\end{array}$ & $\begin{array}{l}\text { Português não é uma língua fácil de se } \\
\text { encontrar aulas. }\end{array}$ \\
\hline $\begin{array}{l}\text { [...] na Inglaterra os colégios, as escolas } \\
\text { ensina francês, alemão, espanhol, } \\
\text { porque [...] normalmente não. }\end{array}$ & $\begin{array}{l}\text { [...] na Inglaterra as escolas ensinam } \\
\text { francês, alemão, espanhol, mas } \\
\text { português normalmente não. }\end{array}$ \\
\hline $\begin{array}{l}{[\ldots] \text { e também eles querem os }} \\
\text { estrangeiros entender. }\end{array}$ & $\begin{array}{l}{[\ldots] \text { e também eles querem que os }} \\
\text { estrangeiros entendam. }\end{array}$ \\
\hline $\begin{array}{l}{[\ldots] \text { Paris, por exemplo, sem }} \\
\text { conhecimento cem por cento. }\end{array}$ & $\begin{array}{l}\text { Em Paris, por exemplo, sem cem por } \\
\text { cento de conhecimento [...] }\end{array}$ \\
\hline $\begin{array}{l}\text { No Brasil, os brasileiros ajudam, mas a } \\
\text { maioria dos estrangeiros uma dividio que } \\
50 \% \text { inglês, } 50 \% \text { português. }\end{array}$ & $\begin{array}{l}\text { No Brasil, os brasileiros ajudam (têm } \\
\text { boa vontade e paciência), pois a } \\
\text { maioria dos estrangeiros apresentam } \\
\text { uma mistura (uma divisão na fala): } 50 \% \\
\text { inglês, } 50 \% \text { português. }\end{array}$ \\
\hline $\begin{array}{l}{[\ldots] \text { - uma conversa po }} \\
\text { mas usando as duas língua }\end{array}$ & $\begin{array}{l}{[\ldots] \text { - fica (torna-se) uma conversa um }} \\
\text { pouco estranha, pois estão usando as } \\
\text { duas línguas }[. . .]\end{array}$ \\
\hline $\begin{array}{l}\text { ficuldade para mim da língua é } \\
\text { ática. }\end{array}$ & e para mim na língua \\
\hline Então [...] & Então [...] \\
\hline$[\ldots]$ um pe & $\begin{array}{l}\text { Agora há (está) lá uma pessoa } \\
\text { diferente. }\end{array}$ \\
\hline $\begin{array}{l}\text { Eu estou falando com pessoa, com } \\
\text { certeza, não vai estar lá durante } 99 .\end{array}$ & $\begin{array}{l}\text { Eu estou falando com uma pessoa que, } \\
\text { com certeza, não vai estar lá (no mesmo } \\
\text { cargo) em } 99 \text {. }\end{array}$ \\
\hline $\begin{array}{l}{[\ldots] \text { mas o processo talvez }[\ldots] \text { não está }} \\
\text { confirmado. }\end{array}$ & $\begin{array}{l}{[\ldots] \text { talvez (isso aconteça), mas a }} \\
\text { realização (concretização) não está } \\
\text { confirmada. }\end{array}$ \\
\hline $\begin{array}{l}\text { Quatro ou cinco anos eu acho que eu vou } \\
\text { ficar aqui. }\end{array}$ & $\begin{array}{l}\text { Eu acho que eu vou ficar a } \\
\text { quatro ou cinco anos. }\end{array}$ \\
\hline $\begin{array}{l}\text { Não é possível ficar com uma vez até } \\
\text { uma promoção. }\end{array}$ & $\begin{array}{l}\text { Não é possível ficar (permanecer) a } \\
\text { primeira vez no mesmo país (mais } \\
\text { tempo) até (para) obter (ganhar) uma } \\
\text { promoção. }\end{array}$ \\
\hline $\begin{array}{l}\text { Eu acho que eu vou voltar para } \\
\text { Inglaterra, outro país, mas não é [...] }\end{array}$ & $\begin{array}{l}\text { Eu acho que eu vou voltar para a } \\
\text { Inglaterra ou para outro país, mas não é } \\
\text { nada certo. }\end{array}$ \\
\hline $\begin{array}{l}\text { Você tem cultura artística e também nós } \\
\underline{\text { temos }} \text { o mundo diplomático. }\end{array}$ & $\begin{array}{l}\text { Nós temos não só eventos culturais e } \\
\text { artísticos (brasileiros), como também o }\end{array}$ \\
\hline
\end{tabular}




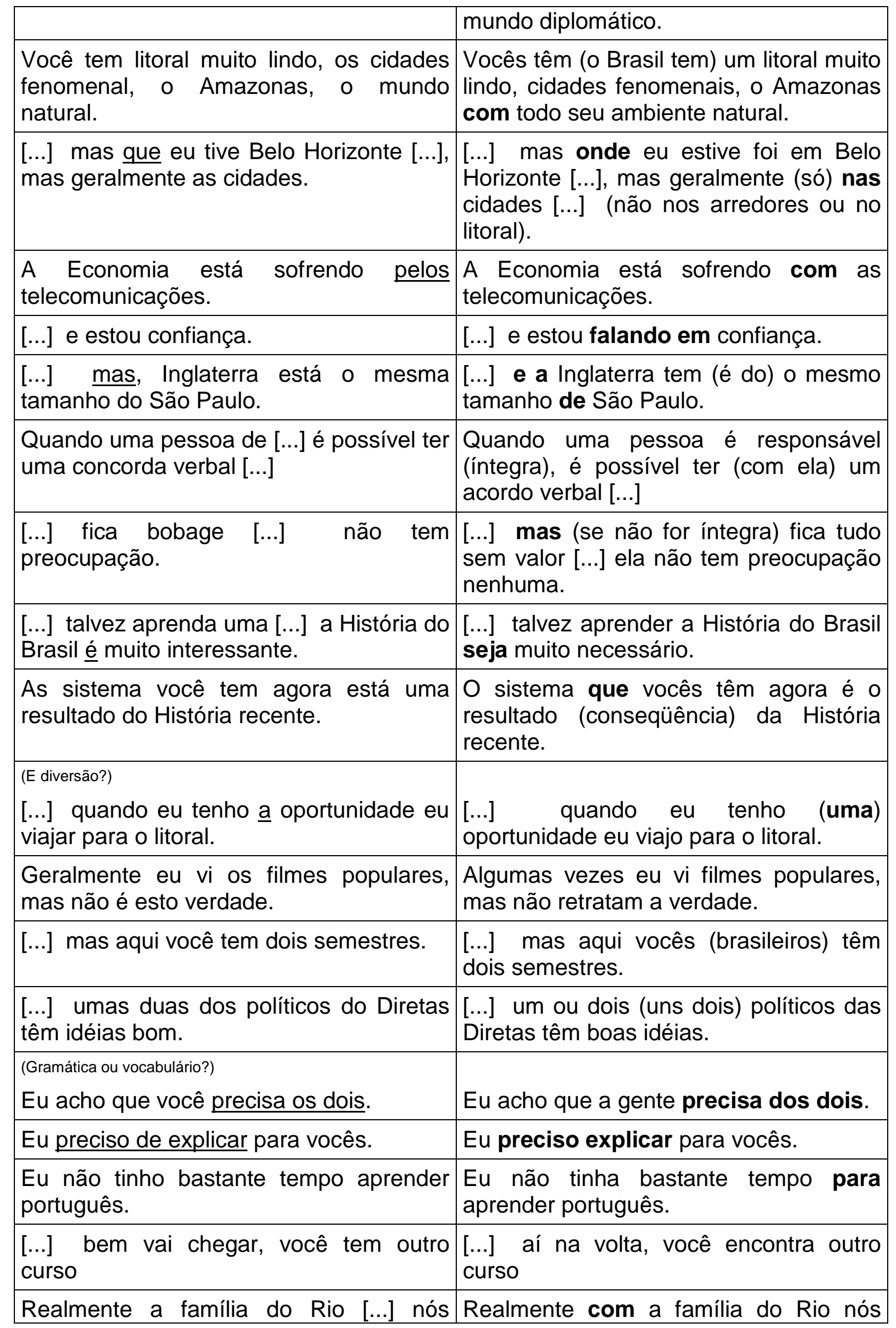




\begin{tabular}{|c|c|}
\hline aprendemos como vivar no Brasil. & aprendemos como viver no Brasil. \\
\hline (Família grande?) & \\
\hline Dois filhos: filha, filho. & Dois filhos: uma filha e um filho. \\
\hline $\begin{array}{l}{[\ldots] \text { mas dentro o mesmo prédio a erma }} \\
\text { da esposa }[. . .]\end{array}$ & $\begin{array}{l}{[\ldots] \text { mas no mesmo prédio mora a irmã }} \\
\text { da esposa }[\ldots]\end{array}$ \\
\hline $\begin{array}{l}\text { Eu tinho umas ou duas desastres no } \\
\text { supermercado }[\ldots]\end{array}$ & $\begin{array}{l}\text { Eu cometi alguns enganos (equívocos, } \\
\text { burradas) no supermercado [...] }\end{array}$ \\
\hline [...] com cheque primeiro vez - a línea. & $\begin{array}{l}\text { [...] na primeira vez que preenchi a linha } \\
\text { do cheque. }\end{array}$ \\
\hline $\begin{array}{l}{[\ldots] \text { a menina do supermercado não }} \\
\text { entende eu sou inglesa e não tenho um } \\
\text { sistema de cheque. }\end{array}$ & $\begin{array}{l}\text { [...] a menina do supermercado não } \\
\text { percebeu que eu sou inglesa e não } \\
\text { tenho hábito (costume) de pagar com } \\
\text { cheque. }\end{array}$ \\
\hline $\begin{array}{l}{[\ldots] \text { perto do Hospital do Samaritano. O }} \\
\text { mundo conheço. }\end{array}$ & $\begin{array}{l}\text { [...] perto do Hospital Samaritano. Todo } \\
\text { mundo conhece. }\end{array}$ \\
\hline $\begin{array}{l}\text { Eu acho que ele cheguei }[\ldots] \text { chegou do } \\
\text { entero - enterior do São Paulo. }\end{array}$ & $\begin{array}{l}\text { Eu acho que (parecia que) ele chegou } \\
\text { (tinha chegado) do interior de São } \\
\text { Paulo. }\end{array}$ \\
\hline $\begin{array}{l}{[\ldots] \text { quando meu }[. . .] \text { minha primeira vez }} \\
\text { com um VIP. }\end{array}$ & $\begin{array}{l}{[\ldots] \text { quando fui me encontrar pela }} \\
\text { primeira vez com um VIP. }\end{array}$ \\
\hline eu não sube sobre entra aero. & $\begin{array}{l}\text { Eu não sabia (como) entrar no } \\
\text { aeroporto. }\end{array}$ \\
\hline $\begin{array}{l}\text { Nós fomos pra aeroporto sabendo nado } \\
\text { conjunto. }\end{array}$ & $\begin{array}{l}\text { Nós fomos para o aeroporto, mas } \\
\text { nenhum dos dois sabia (conhecia) nada } \\
\text { (nem eu, nem ele conhecia nada). }\end{array}$ \\
\hline $\begin{array}{l}\text { Meu VIP chegou aqui atrasado com } \\
\text { conferência, sem os roupas formals. }\end{array}$ & $\begin{array}{l}\text { Meu VIP chegou aqui (ao aeroporto) } \\
\text { atrasado para a conferência e sem as } \\
\text { roupas formais. }\end{array}$ \\
\hline $\begin{array}{l}{[\ldots] \text { e nós realmente nós têm bem }} \\
\text { sucesso com os roupas formal, meo, } \\
\text { gravatos, camisetas. }\end{array}$ & $\begin{array}{l}{[\ldots] \text { e nós realmente fizemos um }} \\
\text { sucesso total com as roupas formais } \\
\text { (que eu comprei): gravatas, camisetas } \\
\text { (camisas). }\end{array}$ \\
\hline $\begin{array}{l}\text { Eu tenho a responsabilidade das Artes do } \\
\text { Conselho no Brasil. }\end{array}$ & $\begin{array}{l}\text { Eu tenho a responsabilidade sobre } \\
\text { Artes organizadas pelo Conselho no } \\
\text { Brasil. }\end{array}$ \\
\hline Nós ficar com o apartamento deles. & Nós ficávamos no apartamento deles. \\
\hline $\begin{array}{l}{[\ldots] \text { quando vocêm fale português tudos }} \\
\text { o dia com uma pessoa durante a noite é } \\
\text { muito dificíl }[. . .]\end{array}$ & $\begin{array}{l}{[\ldots] \text { quando você (a gente) fala }} \\
\text { português o dia inteiro (todo o dia) com } \\
\text { uma pessoa, durante a noite é muito } \\
\text { difícil }[\ldots]\end{array}$ \\
\hline $\begin{array}{l}{[\ldots] \text { até jantar nós fomos muito }} \\
\text { descansada. }\end{array}$ & $\begin{array}{l}{[\ldots] \text { até no jantar nós ficávamos }} \\
\text { calados. }\end{array}$ \\
\hline
\end{tabular}




\begin{tabular}{|c|c|}
\hline $\begin{array}{l}\text { Nós não tínhamos outro palavras e } \\
\text { também nós aprendemos só gramática, } \\
\text { sem vocabulário. }\end{array}$ & $\begin{array}{l}\text { Nós não conhecíamos outras palavras } \\
\text { porque nós aprendíamos só gramática, } \\
\text { pouco vocabulário. }\end{array}$ \\
\hline $\begin{array}{l}{[\ldots] \text { uma pessoa que vem aqui precisa o }} \\
\text { vocabulário porque as pessoas do Brasil } \\
\text { estão muito simpático com estrangeiros. }\end{array}$ & $\begin{array}{l}\text { [...] uma pessoa que vem para cá } \\
\text { (Brasil) precisa de vocabulário embora } \\
\text { os brasileiros sejam muito amáveis com } \\
\text { os estrangeiros. }\end{array}$ \\
\hline $\begin{array}{l}\text { Fala português! Você vai aprender pelo } \\
\text { falando, mas não verdade }[. . .]\end{array}$ & $\begin{array}{l}\text { Fale português! Você vai aprender } \\
\text { falando (pela fala, através da fala), } \\
\text { mas (isso) não é verdade [...] }\end{array}$ \\
\hline $\begin{array}{l}\text { Eu acho que você precisa escutar, } \\
\text { porque o rádio, por exemplo, agora eu } \\
\text { posso entendo as notícias. }\end{array}$ & $\begin{array}{l}\text { Eu acho que a gente precisa ouvir, mas } \\
\text { o rádio, por exemplo, (no início eu não } \\
\text { conseguia entender) agora eu (já) posso } \\
\text { entender as (suas) notícias (notícias } \\
\text { dele). } \\
\text { ou } \\
{[\ldots] \text {. mas o rádio, por exemplo, que eu }} \\
\text { não conseguia entender no início, agora } \\
\text { eu (já) posso [...] }\end{array}$ \\
\hline $\begin{array}{l}\text { Eu ouça, [...] destaques: Manaus } \\
\text { parrrrrrrrrrr. }\end{array}$ & $\begin{array}{l}\text { Eu ouvia notícias em destaque Manaus } \\
{[\ldots]}\end{array}$ \\
\hline $\begin{array}{l}\text { Não é póssivel aprender, masdurante o } \\
\text { primeiro ano eu tentei bem escutar } \\
\text { português. }\end{array}$ & $\begin{array}{l}\text { Não foi possível aprender, embora } \\
\text { durante o primeiro ano eu tentasse } \\
\text { bastante ouvir português. } \\
\text { ou } \\
{[\ldots] \text { durante o primeiro ano eu tentei }} \\
\text { muito ouvir português, mas não foi } \\
\text { possível aprender. }\end{array}$ \\
\hline Ele tem uma obsessão com o subjuntivo. & Ela tinha uma obsessão pelo subjuntivo. \\
\hline $\begin{array}{l}\text { Esta parte do gramática é mais dificíl por } \\
\text { as pessoas que fala inglês. }\end{array}$ & $\begin{array}{l}\text { Esta parte da gramática é mais difícil } \\
\text { para as pessoas que falam inglês. }\end{array}$ \\
\hline $\begin{array}{l}{[\ldots] \text { realmente eu gosto fala português, }} \\
\text { mas it's }[\ldots]\end{array}$ & $\begin{array}{l}{[\ldots] \quad \text { realmente eu gosto de falar }} \\
\text { português, mas (porém) "it's difficult". }\end{array}$ \\
\hline (Como se sentiu na entrevista?) & \\
\hline $\begin{array}{l}\text { Eu estou nervioso você vai usar por uma } \\
\text { outra assunto. }\end{array}$ & $\begin{array}{l}\text { Eu estou preocupada porque você pode } \\
\text { usar (esta entrevista) para uma outra } \\
\text { finalidade. }\end{array}$ \\
\hline $\begin{array}{l}\text { Eu fui }[. . .] \text {. I was very unhappy o primeiro } \\
\text { ano aqui. }\end{array}$ & $\begin{array}{l}\text { Eu me senti muito infeliz no primeiro ano } \\
\text { aqui. }\end{array}$ \\
\hline $\begin{array}{l}\text { E também eu tinha uma professor que } \\
\text { aprendo inglês na Estados Unidos e [...] }\end{array}$ & $\begin{array}{l}\text { E, além disso, eu tive uma professora } \\
\text { que aprendeu inglês nos Estados } \\
\text { Unidos e }[\ldots]\end{array}$ \\
\hline
\end{tabular}




\begin{tabular}{|c|c|}
\hline $\begin{array}{l}{[\ldots] \text { mas nem eu não tenho um talento }} \\
\text { bem da língua. }\end{array}$ & $\begin{array}{l}{[\ldots] \text { mas também eu não tenho muita }} \\
\text { facilidade (habilidade) para essa língua } \\
\text { (um bom desempenho na língua). }\end{array}$ \\
\hline $\begin{array}{l}{[\ldots] \text { mas eu }[\ldots] \text { eu tinho, tinha a }} \\
\text { responsabilidade por o desenvolvimento } \\
\text { das aulas. }\end{array}$ & $\begin{array}{l}{[\ldots] \quad \text { mas eu é que tinha a }} \\
\text { responsabilidade pelo desenvolvimento } \\
\text { (andamento) das aulas. }\end{array}$ \\
\hline $\begin{array}{l}\text { Porque você precisa }[\ldots] \text {, por exemplo, } \\
\text { você gostaria aprender inglês, você vai } \\
\text { ficar lá uns seis meses. }\end{array}$ & $\begin{array}{l}\text { Se você precisa [...] (ou), por exemplo, } \\
\text { se você gostaria de aprender inglês, } \\
\text { você deve ficar lá (na Inglaterra) uns } \\
\text { seis meses. }\end{array}$ \\
\hline $\begin{array}{l}{[\ldots] \text { e eles têm uma "advantage", }} \\
\text { avantage porque as pessoas da escritório } \\
\text { fala inglês bem, fala português bem. }\end{array}$ & $\begin{array}{l}{[\ldots] \text { e eles têm uma vantagem (sobre }} \\
\text { mim), pois o pessoal do escritório fala } \\
\text { bem inglês e português. }\end{array}$ \\
\hline $\begin{array}{l}{[\ldots] \text { então eu falei inglês porque eu }} \\
\text { precisei }^{89} \text { ter uma posição do chefe. }\end{array}$ & $\begin{array}{l}\text { Eu falava, então, inglês porque eu } \\
\text { precisava assumir uma postura de } \\
\text { chefe. }\end{array}$ \\
\hline
\end{tabular}


ANEXO - E - Registro das formações do -ING

\begin{tabular}{|c|c|}
\hline \multicolumn{2}{|c|}{ NOUNS + ING } \\
\hline BANKING & MARKETING \\
HEADING & BRIDGINGS \\
HANDING & SHIPPING \\
FOOTING & FLAGGING \\
FINGERING & MAPPING \\
LEGGING & DOGGING \\
MOUTHING & HOUSING \\
STOMACHING & ROOMING \\
BOOTING & WINDOWING \\
SHOEING & SEASONING \\
BOOKING & GARDENING \\
WORDING & FLOWERING \\
PENCILLINGS & WATERING \\
CHAIRING & AGEING \\
SCHOOLING & STARRING \\
CLOCKING & DIETING \\
& \\
\hline
\end{tabular}
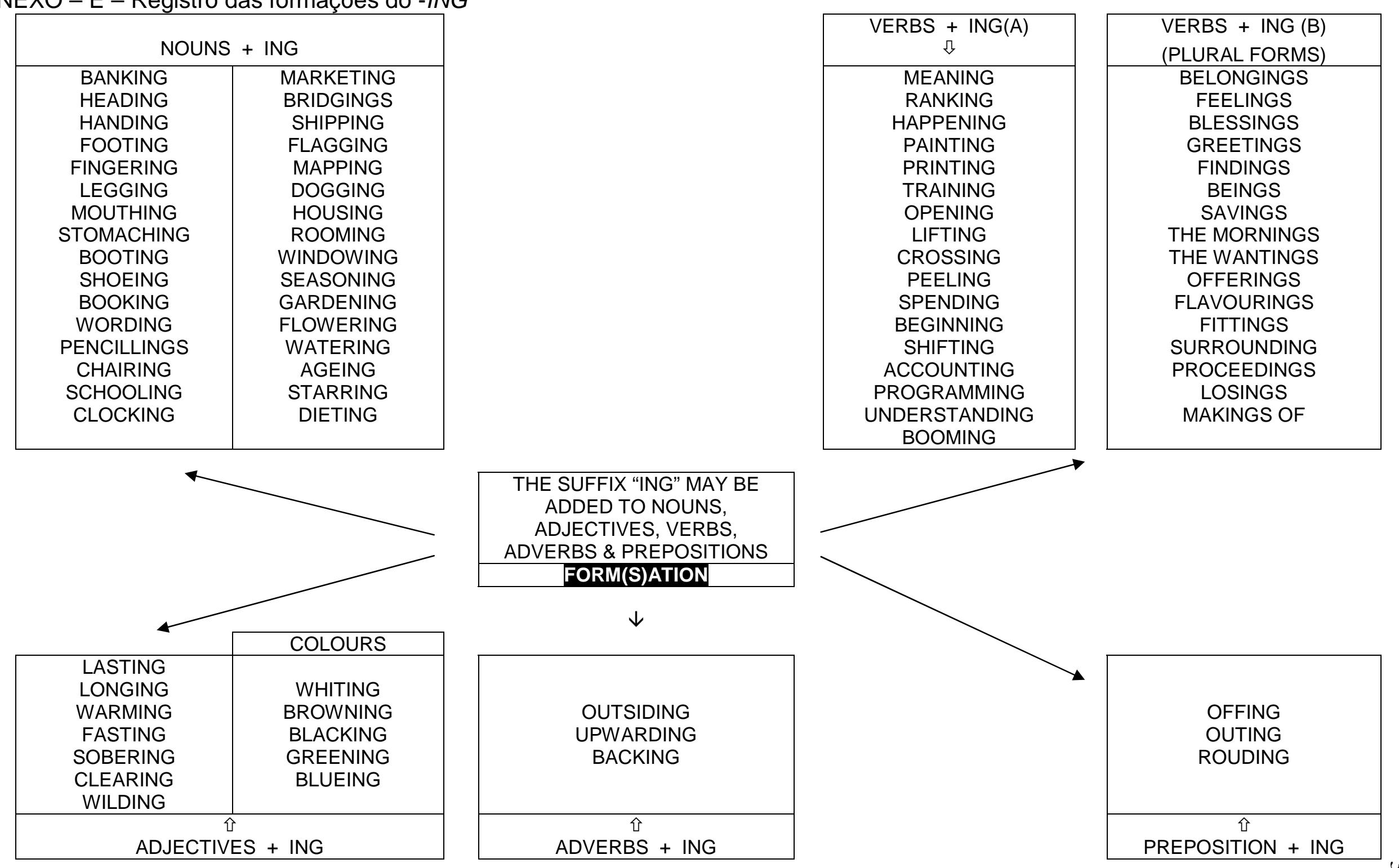
ANEXO - F - Registro das posições do - ING

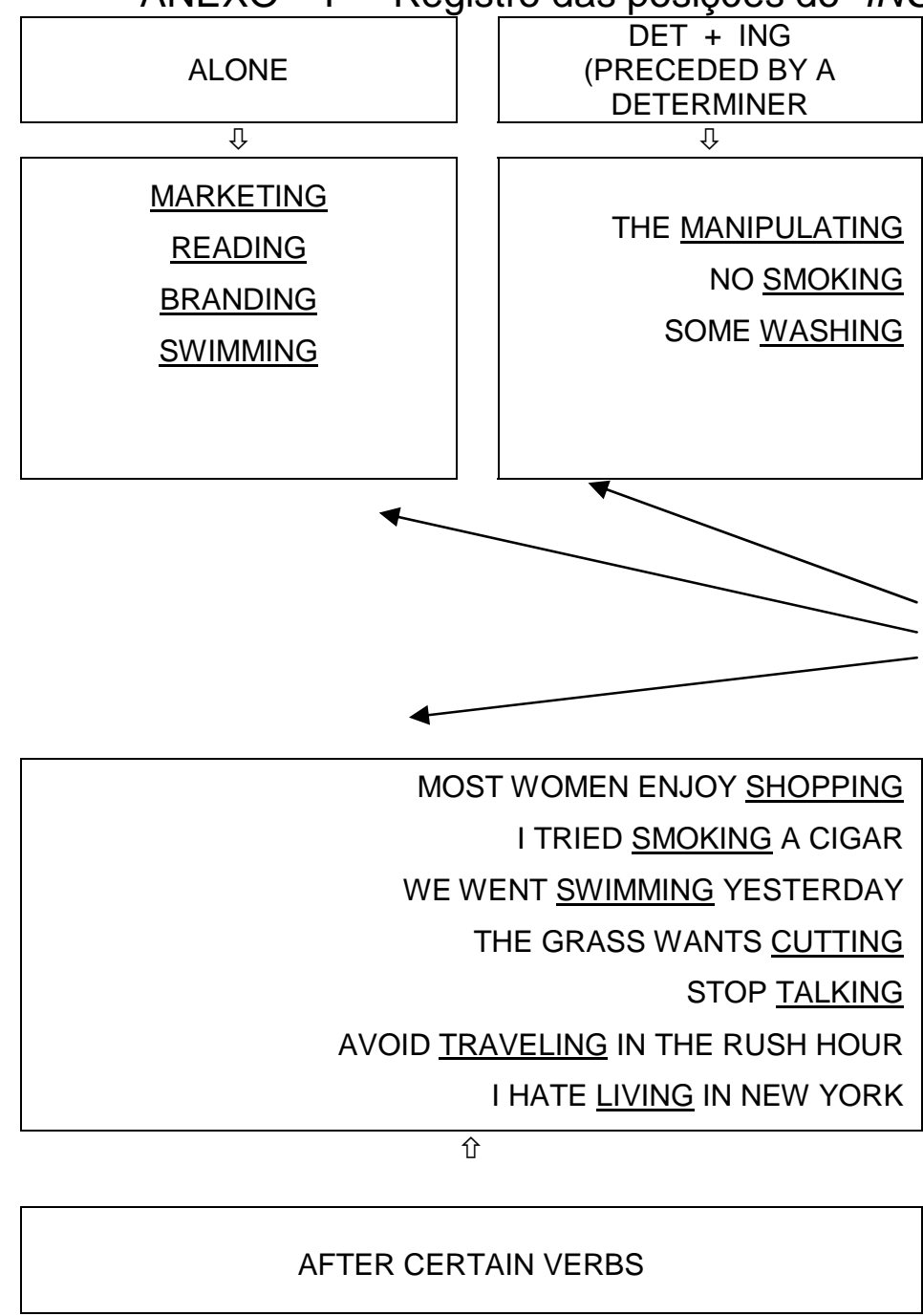
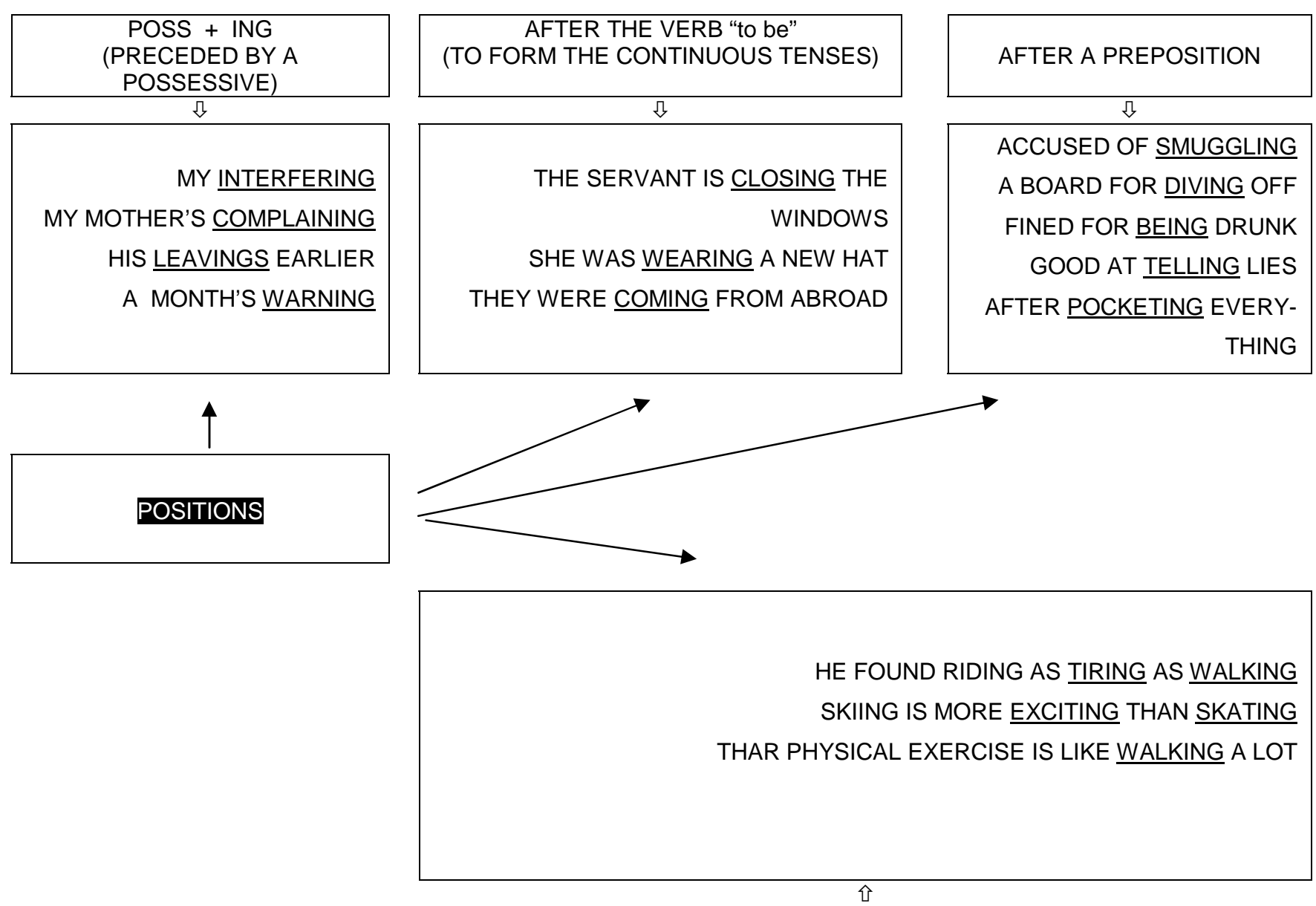

AFTER THE ELEMENTS OF COMPARISON:' LIKE, AS [...]AS, THAN 
ANEXO - G - Registro das combinações do - ING

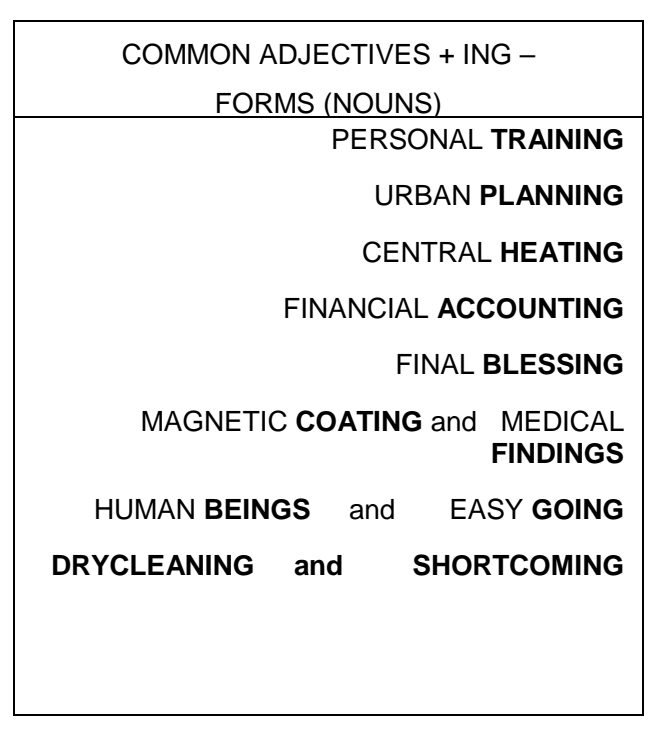

$\kappa$

\begin{tabular}{c} 
LEARNING PROCEEDINGS \\
BORING CHATTING \\
ANTI-SMOKING ADVERTISING \\
A BURNING BUILDING \\
EVERLASTING SEARCHING \\
APPERALING HEADINGS \\
ASTONISHING HAPPENINGS \\
ENTERTAINING PICTURING \\
\hline ING-FORMS (ADJECTIVES) + ING-FORMS \\
(NOUNS) \\
\hline
\end{tabular}

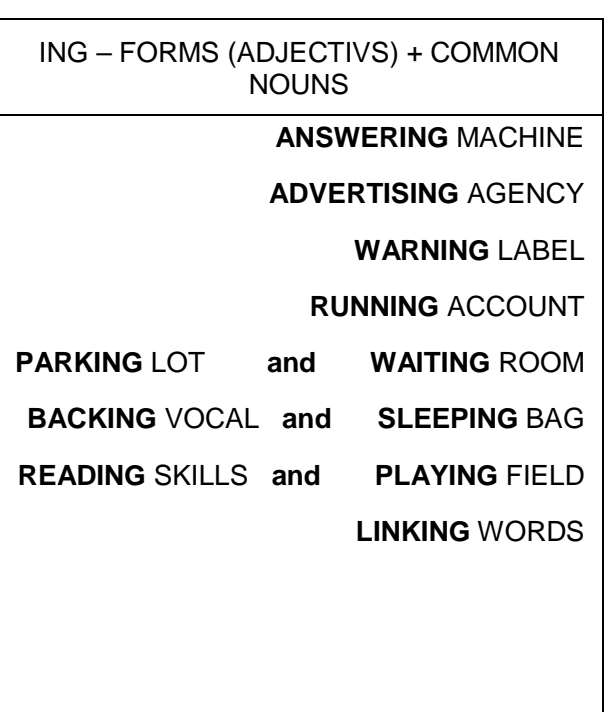

ING - FORMS (NOUNS) + COMMON NOUNS

HOUSING PROBLEMS and SHIPPING CLERK

BOOKING OFFICE and MAILING ADEDRESS

ROOMING HOUSES and PLUMBING SYSTEM

MARKETING RESEARCH STAFFING REQUIREMENTES TIMING PROBLEMS NEIGHBOURING COUNTRIES CLOTHING DEPARTMENT

$\uparrow$

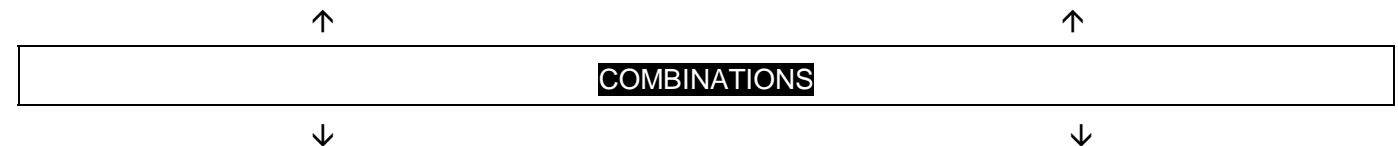

$\downarrow$

\begin{tabular}{c} 
WEDDING CELEBRATING \\
BANKING FILING \\
FILMING COMMANDING \\
TIMING ESTABLISHING \\
GARDENING PROJECTING \\
BRANDING SUPERVISING \\
\\
\hline ING-FORMS (NOUNS) + ING-FORMS \\
(NOUNS)
\end{tabular}

$\downarrow$

\begin{tabular}{|c|} 
FAR-REACHING \\
HARDWORKING \\
WELCOMING \\
EVERLASTING \\
EVERCHANGING \\
NEAR-SIGHTING \\
\\
\hline ADVERBS+ING-FORMS \\
\hline
\end{tabular}

COMMON NOUNS + ING FORMS (NOUNS)

DATA PROCESSING

CODE READING

ERROR CHECKING

SOFTWARE ENGINEERING

CEREAL FARMING

HORSE RACING

AIR CONDITIONING

EMERGENCY LANDING

STAMP-COLLECTING

BRAINWASHING

DRUG-TAKING

SALAD DRESSING

VEGETABLES \& FISH DIETING

\section{$\pi$}

\begin{tabular}{|c|}
\hline \\
\hline OVERCOMING \\
OVERBOOKING \\
UPGRADING \\
UNDERTAKING \\
OUSTANDING \\
UNDERSTANDING \\
PLURAL FORMS: \\
HOLDING-UPS \\
TAKING-OFFS \\
\hline PREPOSITIONS+ING-FORMS \\
\hline
\end{tabular}


ANEXO - H - Registro das funções do - ING

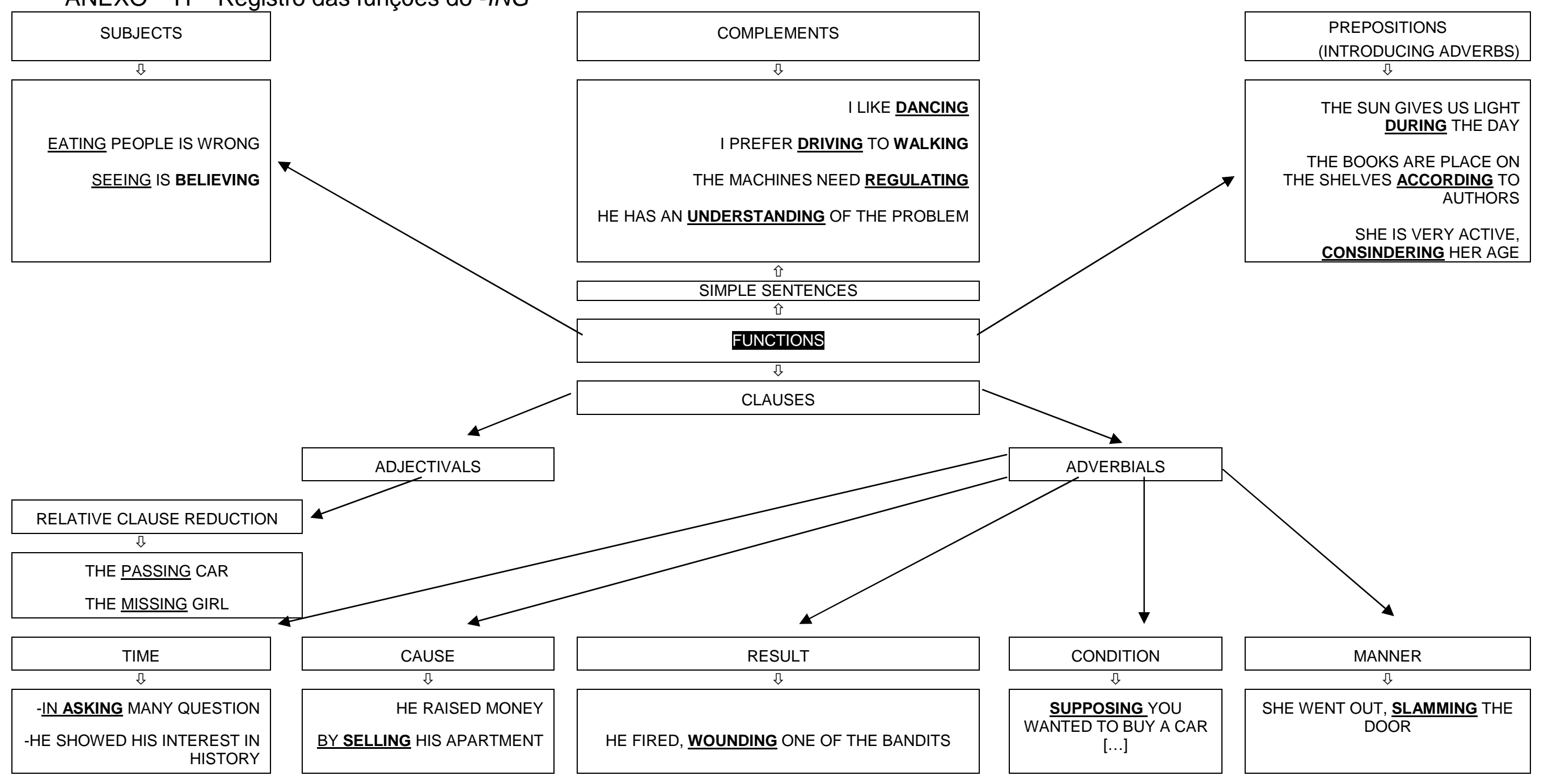

